\title{
'Hoofdverpleegkundigen' over leven in het ziekenhuis : een onderzoek naar de rolonduidelijkheid van hoofdverpleegkundigen
}

Citation for published version (APA):

van den Bergh-Braam, A. (1984). 'Hoofdverpleegkundigen' over leven in het ziekenhuis : een onderzoek naar de rolonduidelijkheid van hoofdverpleegkundigen. [, Maastricht University]. Rijksuniversiteit Limburg. https://doi.org/10.26481/dis.19840608ab

Document status and date:

Published: 01/01/1984

DOI:

10.26481/dis.19840608ab

Document Version:

Publisher's PDF, also known as Version of record

Please check the document version of this publication:

- A submitted manuscript is the version of the article upon submission and before peer-review. There can be important differences between the submitted version and the official published version of record.

People interested in the research are advised to contact the author for the final version of the publication, or visit the DOI to the publisher's website.

- The final author version and the galley proof are versions of the publication after peer review.

- The final published version features the final layout of the paper including the volume, issue and page numbers.

Link to publication

\footnotetext{
General rights rights.

- You may freely distribute the URL identifying the publication in the public portal. please follow below link for the End User Agreement:

www.umlib.nl/taverne-license

Take down policy

If you believe that this document breaches copyright please contact us at:

repository@maastrichtuniversity.nl

providing details and we will investigate your claim.
}

Copyright and moral rights for the publications made accessible in the public portal are retained by the authors and/or other copyright owners and it is a condition of accessing publications that users recognise and abide by the legal requirements associated with these

- Users may download and print one copy of any publication from the public portal for the purpose of private study or research.

- You may not further distribute the material or use it for any profit-making activity or commercial gain

If the publication is distributed under the terms of Article $25 \mathrm{fa}$ of the Dutch Copyright Act, indicated by the "Taverne" license above, 
'HOOFDVERPLEEGKUNDIGEN'

OVER LEVEN

IN HET ZIEKENHUIS 


\section{'HOOFDVERPLEEGKUNDIGEN' OVER LEVEN IN HET ZIEKENHUIS}

Een onderzoek naar de rolonduidelijkheid van hoofdverpleegkundigen

\section{PROEFSCHRIFT}

Ter verkrijging van de graad van doctor in de Sociale Wetenschappen aan de Rijksuniversiteit Limburg te Maastricht, op gezag van de Rector Magnificus Prof. Dr. H.C. Hemker, volgens besluit van het College van Dekanen, in het openbaar te verdedigen in de aula van de Rijksuniversiteit op vrijdag 8 juni 1984 des namiddags te vier uur

door

Anneke van den Bergh-Braam

Geboren te Gendt (Gld.) 
Promotores: Prof. Dr. Ch.J. de Wolff

Prof. Dr. H. Philipsen

Referenten: intern: Prof. Dr. F. Sturmans

extern: Prof. Dr. J.A.C. de Kock van Leeuwen 


\section{Inhoud}

Voorwoord 7

Hoofdstuk 1 Aanleiding en voorbereiding voor het onderzoek 9

$\begin{array}{lr}\text { Hoofdstuk } 2 \text { Literatuurbevindingen } & 15\end{array}$

2.1 De ontwikkeling van de verpleging en het ziekenhuis 15

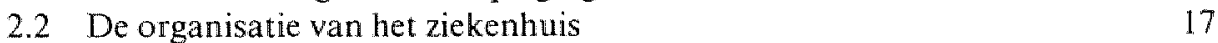

2.3 Specialisten en hoofdverpleegkundigen 26

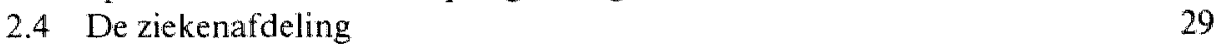

2.5 De hoofdverpleegkundigen en hun staf 38

2.6 De patiënten 51

Hoofdstuk 3 Vraagstellingen voor het hoofdonderzoek $\quad 57$

3.1 Probleemkeuze 57

3.2 Het conceptueel kader: het stressmodel $\quad 59$

3.3 Rol-theoretische achtergrond 61

$\begin{array}{ll}3.4 & \text { Literatuur over rolonduidelijkheid }\end{array}$

$\begin{array}{lll}3.5 & \text { Vraagstellingen } & 73\end{array}$

$\begin{array}{lll}3.6 & \text { Samenvatting } & 75\end{array}$

Hoofdstuk 4 Opzet van het onderzoek $\quad 77$

Hoofdstuk 5 Rolonduidelijkheid en taakonduidelijkheid van hoofdverpleeg$\begin{array}{ll}\text { kundigen } & 91\end{array}$

5.1 Omschrijving en meting centrale variabele rolonduidelijkheid 91

5.2 Mate waarin hoofdverpleegkundigen rol(on)duidelijkheid ervaren in vergelijking met andere beroepsgroepen $\quad 94$

5.3 Taken en contacten van hoofdverpleegkundigen 94

5.4 Verbanden tussen gezamenlijke taak(on)duidelijkheid en ervaren rol(on)duidelijkheid 112

5.5 Samenvatting 114

$\begin{array}{ll}\text { Hoofdstuk } 6 \text { Rolonduidelijkheid van hoofdverpleegkundigen } & 117\end{array}$

6.1 Verschillen in percepties van hoofdverpleegkundigen en role-senders over rolrelevante aspecten $\quad 118$

6.2 Meningen van role-senders onderling over rolrelevante aspecten $\quad 120$

6.3 Correlaties tussen ervaren rolonduidelijkheid van hoofdverpleeg-

6.4 Correlaties tussen ervaren rolonduidelijkheid van hoofdverpleegkundigen en meningen van role-senders over intermenselijke rol$\begin{array}{ll}\text { aspecten } & 122\end{array}$

$\begin{array}{lll}6.5 & \text { Samenvatting } & 123\end{array}$

Hoofdstuk 7 Ervaren rolonduidelijkheid, institutionelle context en werkaspecten 125 
7.1 Correlaties tussen erwaren rol(on)duidelijkheid met stressoren en strains 125

7.2 Samenvatting en discussie

Hoofdstuk 8 Rigiditeit vam hoofdverpleegkundigen en relaties met ervaren rolonduidelijkiheid

8.1 Rigiditeit en flexibiliteit

8.2 Gezamenlijke taak(on)duidelijkheid en rigiditeit/flexibiliteit

8.3 Conditionerende effecten van rigiditeit/flexibiliteit op de relatie tussen gezamenlijke taak(on)duidelijkheid en ervaren rol(on)duidelijkheid

8.4 Relatie tussen rigiditeit/flexibiliteit en ervaren rol(on)duidelijkheid

8.5 Conditionerende effecten van rigiditeit/flexibiliteit op de relaties tussen ervaren rol(on)duidelijkheid en enkele stressoren en strains

8.6 Verband tussen leeftijd, geslacht en burgerlijke staat met de ervaren rol(on)duidelijkheid van hoofdverpleegkundigen

8.7 Samenvatting

Hoofdstuk 9 Ervaren rolond uidelijkheid van hoofdverpleegkundigen en intermenselijke verhoudingen

9.1 Intermenselijke verhoudingen en sociale ondersteuning

9.2 Gezamenlijke taak(on)duidelijkheid bij gunstige/minder gunstige intermenselijke verhoudingen (zoals waargenomen door role-senders)

9.3 Conditionerende effecten van gunstige/minder gunstige intermenselijke werhoudingen (zoals ervaren door role-senders) op de relatie tussen gezamenlijke taak(on)duidelijkheid en ervaren rol(on)duidelijkheid

9.4 Relatie tussen gunstige/minder gunstige intermenselijke verhoudingen (bezien vanuit role-senders) en ervaren rol(on)duidelijkheid en enkele stressoren en strains

9.5 Conditionerende effecten van gunstige/minder gunstige intermenselijke verhoudingen (bezien vanuit role-senders) op de relaties tussen ervaren rol(on)duidelijkheid en enkele stressoren en strains

9.6 Gezamenlijke taak(on)duidelijkheid bij gunstige/minder gunstige sociale ondersteuning (bezien vanuit hoofdverpleegkundigen)

9.7 Conditionerende effecten van gunstige/minder gunstige sociale ondersteuning (bezien vanuit hoofdverpleegkundigen) op de relatie tussen gezamenlijke taak(on)duidelijkheid en ervaren rol(on)duidelijkheid

9.8 Relatie tussen gunstige/minder gunstige sociale ondersteuning (bezien vanuit hoofdverpleegkundigen) en ervaren roll(on)duidelijkheid van hoofdverpleegkundigen

9.9 Conditionerende effecten van gunstige/minder gunstige sociale ondersteuning (zoals ervaren door hoofdverpleegkundigen) op de relaties tussen ervaren rolonduidelijkheid en enkele stressoren en strains

9.10 Samenvatting

Hoofdstuk 10 Samenvatting en discussie

Chapter 10 Summary and discussion

Literatuuropgave

Bijlagen 


\section{Voorwoord}

Dit proefschrift is een onderdeel van een onderzoek dat de werkproblemen bestudeert van hoofdverpleegkundigen in ziekenhuizen.

$\mathrm{Na}$ de start in 1978 hebben velen op uiteenlopende wijze hun bijdragen aan onderzoek en rapportage verleend. In de rij van hen die ik graag wil bedanken voor de ondervonden hulp en steun, komen op de eerste plaats directies van ziekenhuizen, coördinerend hoofdverpleegkundigen, hoofdverpleegkundigen, specialisten, gediplomeerden en leerlingen, die bereid waren hun aandeel in het onderzoek te leveren.

Het Ministerie van Welzijn, Volksgezondheid en Cultuuren de Katholieke Universiteit te Nijmegen, wil ik speciaal noemen als instanties die door financiële bijdragen dit onderzoek ondersteunden. Mevrouw J.J. von Nordheim, inspecteur van de volksgezondheid inzake verplegende en verzorgende beroepen, ben ik erkentelijk voor haar inzet bij de realisering van dit project.

De Nationale Ziekenhuisraad te Utrecht will ik bedanken voor zijn medewerking in de vorm van een brief, waarin hij ziekenhuizen verzocht a an het onderzoek te participeren.

Bijzondere dank wil ik richten aan beide promotoren, professor dr. Ch.J.de Wolffen professor dr. H. Philipsen; De Wolff speciaal voor zijn stimullerende invloed bij de startfase en het veldwerk; Philipsen vooral voor de methodologische begeleiding van de analyse-fase.

Vervolgens wil ik mijn erkentelijkheid en dank betuigen aan professor dr. F. Sturmans als interne referent en professor dr. J.A.C. de Kock van Leeuwen als externe referent.

Dank ben ik ook verschuldigd aan dr. J.A.M. Winnubst, die als coördinator van de Stress-groep Nijmegen steeds speciale belangstelling toonde.

Ook de leden van de begeleidingscommissie hebben door hun inspirerende belangstelling en vakkundig commentaar een wezenlijke bijdrage geleverd aan de voortgang van dit onderzoek. Graag wil ik noemen:

H. Fleur, coördinerend hoofdverpleegkundige, Gemeenteziekenhuis Arnhem.

M. de Haan, geneesheer-directeur Diakonessenziekenhuis Eindhoven.

M. Christilla Post, voormalig directrice St. Radboud-ziekenhuis Nijmegen.

F. Sturmans, epidemioloog Nijmegen en Maastricht, voorzitter van de begeleidingscommissie.

A. v.d. Weg, voormalig verpleegkundig directrice Julianaziekenhuis Apeldoorn.

Ch.J. de Wolff, hoofd vakgroep psychologie van arbeid en organisatie K.U. Nijmegen. 
Ook will ik noemen: Jan Prins, Jo Driesseri en Willem Martens die mijop de letterlijk en figuu rlijk glibberige paden naar de ziekenbuizen winter anno $1978 / 1979$ vergezelden.

Ton de Beer bedank ik voor de vele telefonische boodschappen die hij aan mij doorgaf en voor zijn nooit aflatende bereid heid artikelen voor mij op te zoeken of aan te vragen. Toen het onderzoeksmaterial van Nijmegen naar Maastricht verhuisde, was het vooral Frans Marcelissen die zich daarvoor inzette. Hiervoor mijn hartelijke dank.

In Maastricht mogen niet onvermeld blijven Michel Janssen (capaciteitsgroep medische informatica en statistiek) en Henk Lebens (capaciteitsgroep medische sociologie) die ondanks hun drukke werkzaamheden toch tijd vonden om mij de noodzakelijke computergegevens te verstrekken.

Een bijzonder woord van dank aan Annie Simons en Miranda Beekman, die het manuscript snel en vaardig typten en weranderingen geduldig verwerkten. Ook de bijzonder nauwkeurige wijze waarop de correctie wan de eindtekst en de indeling werd uitgevoerd door Janneke Leunissen, verdient respect en dankbaarheid.

Ook wil ik het faculteitsbestuur van de Rijksuniversiteit Limburg te Maastricht bedanken voor het half jaar verlof dat het mij verleende om dit proefschrift af te ronden. Dit genereus gebaar werd door mij op prijs gesteld. Ik realiseer mij echter goed wat dit verlof voor de capaciteitsgroep-leden moest betekenen.

Als laatsten en zeker niet a ls minsten wil ik noemen mijn echtgenoot en kinderen, die mij steunden met veel hartelijk heid, humoren begrip. Ook mijn familieleden met hun warme belangstelling leverden een positieve bijdrage aan de afronding van dit werk.

Nijmegen/Maastricht, mei 1984. 


\section{Aanleiding en voorbereiding voor het onderzoek}

Louter op hun aantal afgaand zou men verwachten dat het ver pleegkundig personeel in het ziekenhuis een invloedrijke groep is. Bijna de helft van de personeelsleden van de Nederlandse ziekenhuizen (in 198046.200 van de 98.000$)^{1}$ ) is gediplomeerd of leerlingverpleegkundige.

De feiten wijzen erop dat het niet de verpleegkundigen zijn die de toon aangeven in het ziekenhuis. Neem bijvoorbeeld het hoge verloop bijdeze beroepsgroep; dat duidt erop dat zij te maken hebben met ongunstige arbeidsomstandigheden en een frustrerende werksituatie. Van de gediplomeerden verlaat jaarlijks $26 \%$ de arbeidsplaats, om elders een nieuwe baan te aanvaarden, soms buiten het beroep; van de leerlingverpleegkundigen valt $15 \%$ af.

Tabel 1 en 2 geven inzicht in het verloop van verpleegkundigen in algemene ziekenhuizen in Nederland in 1980 en 1982.

Tabel 1. Genniddede verloopciffers ower hed jad $1980^{2}$ )

\begin{tabular}{|c|c|c|c|c|}
\hline & $0-200$ & $200 \cdots 400$ & 400 an & \\
\hline Ziekenhuizen wan" & bedden & bedden & $\begin{array}{l}\text { meer } \\
\text { bedden }\end{array}$ & gemiddeld \\
\hline
\end{tabular}

Gediploneerd verpleegk.

verzorgend en opwoedk. personeel

$25 \%$

$29 \%$

$25 \%$

$26 \%$

Lerling verpleegk.

verzorgend en opvoedk. personeel

$15 \%$

$16 \%$

$15 \%$

$15 \%$

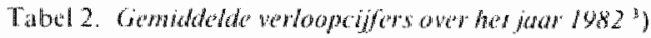

\begin{tabular}{lllll}
\hline Ziekenhuizen wan: & $\begin{array}{l}0-200 \\
\text { bedden }\end{array}$ & $\begin{array}{l}200-400 \\
\text { bedden }\end{array}$ & $\begin{array}{l}400 \text { en } \\
\text { meer } \\
\text { bedden }\end{array}$ & gemiddald \\
\hline $\begin{array}{l}\text { Gediplonterd verpleegk. } \\
\text { verzorgend en opvoedk. personeel }\end{array}$ & $16 \%$ & $15 \%$ & $14 \%$ & $15 \%$ \\
$\begin{array}{l}\text { Leerling verplecgk. } \\
\text { verzorgend en opwoedk. personeel }\end{array}$ & $13 \%$ & $10 \%$ & $11 \%$ & $11 \%$ \\
\hline
\end{tabular}

1) Bron National Ziekenhusinstitut Urecht 1980.

3) Bron Nationaal Ziekenhuisinstimut Utrecht 1980-1982.

3) Bron Nationaal Ziekentuisinstituut Utrecht $1980-1982$. 
Uit vergelijking van tabel $\mathbb{e}$ en 2 blijkt dat het verloop is gedaald, vooral onder gediplomeerden. Waarschijnlijk is de toenemende werkloosheid hierop van invloed. De cijfers unit de tabellen betreffen het landelijk gemiddelde. In sommige ziekenhuizen ligt het verlooppercentage veel hoger. Verweij (1979) zegt dat verlooppercentages van 36-55 procent onder de leerlingen tijdens de opleiding en van 30-40 procent onder de gediplomeerden geen extreme cijfers zijn.

In het buitenland liggen deze getallen niet gunstiger. Redfern (1980) heeft berekend dat in Engeland het verloop van hoofdverpleegkundigen warieert tussen 23 en 40 procent en van gediplomeerden tussen 44 en 82 procent.

\section{Betekenis}

Het verloop onder verpleegkundigen heeft ernstige gevolgen woor de kwalliteit van de patiëntenzorg en van het verpleegkundige beroep. Vacatures blijven soms lang bestaan, waardoor het overgebleven personeel harder moet werken. De slechtere arbeidscondities stimuleren verder verloop. Zo versterken zich de problemen die personeelstekorten met zich meebrengen. Personeelswisselingen verstoren het rustige en vellige afdelingsklimaat, dat noodzakelijk is voor een the rapeutisch milieu (Cassee 1974). De kwaliteit van de patiëntenzorg daalt door gebrek aan aandacht en er komen ongelukken op de afdeling voor.

Vroom (1977) heeft aangetoond dat het aantal ongelukken in een organisatie positief samenhangt met verloop en verzuim. Hij heeft bovendien gevonden dat er een negatief verband bestat tussen arbeidstevredenheid en het ontstaan van ongelukken.

Veelvuldige personeelswisselingen maken het ook moeilijk groepsgevoel te ont wikkelen. Groepsbinding is voor verpleegkundigen erg belangrijk: een affectieve band met de collega's helpt hen bij het bespreken en verwerken van de spanningen van het werk. Vooral voor leerlingen blijkt dat belangrijk te zijn. Van Hecke en Wouters (1969) komen bijvoorbeeld na een longitudinale studie tot de uitspraak dat het verloop onder leerlingen onder meer wordt veroorzaakt door onopgeloste psychische spanningen.

Datzelide is ook aangekaart door Kramer (1974), die spreekt over wat verpleegkundigen doormaken alvorens ze besluiten dat vertrek de enige oplossing is om aan de spanningen te ontkomen. Zij noemt symptomen als angst, boosheid, haat, zelfmedelijden en woede.

De psychische spanningen ontladen zich niet zelden op degenen die in de ogen van het afdelingspersoneel aansprakelijk zij|n voor de slechte gang van zaken: de hoofdverpleegkundigen.

Zij worden soms gezien als de zondebok voor de slechte sfeer. Dat beeld bestaat misschien ook bij het publiek. Denk bijwoorbeeld aan de manier waarop de hoofdverpleegkundige Ratched is getypeerd in de film "One flew over the cuckoo's nest". Het gevaar zit erin dat deze beeldvorming op den duur werkt als een "self fulfilling prophecy', omdat mensen met idealen zich niet meer aangetrokken voelen tot deze functie. 
Ook in de literatuur wordt niet zelden naar hoofdverpleegkundigen gewezen als sleutelfiguren bij het verpleegkundigenverloop. Zo zeggen Cassee en Lammers (1971) dat de verzuimfrequentie van verpleegkundigen afneemt naarmate de hoofdverpleegkundige méer persoonsgericht leiderschapsgedrag vertoont. Gilbertson (1977) wijst op de hoofdverpleegkundige als de stimulator en inspirator op de ziekenafdeling. Als zij haar taak in dit opzicht niet goed vervult kunnen verpleegkundigen hun motivatie verliezen, aldus deze auteur.

Een slechte afdelingssfeer wordt door verschillende auteurs genoemd alseen belangrijke factor bij personeelsverloop.

Zander (1977) signaleert dat hoofdverpleegkundigen nieuwe ontwikkelingen, zoals bv. primary nursing, kunnen tegenhouden. Verpleegkundigen die zich enthousiast voor vernieuwingen inzetten raken hierdoor gedesillusioneerd en vertrekken.

Kramer (1974) wijst op conflicten tussen verpleegkundigen en het afdelingshoofd als zij het niet eens kumnen worden over principiële zaken zoals: wat is eigenlijk verplegen en hoe hoor je dat te doen?

Veel leerling-verpleegkundigen zeggen te weinig contact met de hoofdverpleegkundigen te hebben. Hun kritiek op de afdelingshoofden komt er voornamelijk op neer dat de afdelingshoofden te weinig tijd en belangstelling voor de leerlingen hebben, dat zij zelden complimentjes geven als er goed gewerkt is, dat zij de leerlingen niet begrijpen en dat zij partijdig zijn.

\section{Verweer}

Hoofdverpleegkundigen verweren zich. Zij zeggen met de rug tegen de muur testaan en zich bedreigd te voelen door de vaak niet terechte kritiek van jonge werknemers zonder werkervaring (De Nie, 1977).

Verweij (1981) trekt het persoonlijk falen van hoofdverpleegkundigen in twijfel en wijst structurele oorzaken aan: "De oorzaken van diverse problemen in de verpleging moeten veeleer worden gezocht in het functioneren van het ziekenhuis. $Z_{\mathrm{ij}}$ dienen vooral gezocht te worden in het functioneren van de verplegingsdienst binnen de huidige organisatie van het ziekenhuis".

Karsemeyer (1973) wijst er op dat degenen die zich zorgen maken over de gang van zaken in de gezondheidszorg en daar in het algemeen beleid iets aan kunnen doen, teveel buiten beschouwing laten dat de verplegingsdienst de kerndienst van de institutionele gezondheidszorg vormt. In commissies op het gebied van de gezondheidszorg komt men zo zelden namen van verpleegkundigen tegen.

\section{Aanbevelingen}

De geschetste problematiek is ernstig. De volksgezondheidszorg en de arbeidstevredenheid van mensen werkzaam in de verpleging staan op het spel. Landelijke organisaties gaan zich om deze materie bekommeren.

Het Nationale Ziekenhuisinstituut signaleert in 1976 dat in Nederland onvoldoende onderzocht is welke factoren specifiek zijn voor het verloop onder verpleegkundigen 
enerzijds en leerling-verpleegkundigen anderzijds. De Nationale Ziekenhuisraad formeert een werkgroep met als opdracht het uitwerken van een meer toegespitste typering van het vraagstuk van het tekort aan verpleegkundigen. In het rapport dat deze werkgroep in 1977 uitbracht staat als eerste aanbeveling: "Op korte termijn beginnen met een uitgebreid onderzoek naar de oorzaken".

\section{Uitwerking}

Bovenstaande aanbeveling heb ik persoonlijk ter harte genomen. In de veertienjarige periode dat ik werkzaam was als verpleegkundige heb ik ondervonden hoe bepaalde situaties binnen het ziekenhuis frustrerend werken en dat verpleegkundigen op den du ur vertrek als enige oplossing zien om aan de spanningen te ontkomen. Lang niet de slechtsten vertrokken vroegtijdig. LeShan (1969) verwoordde op een symposium in Amsterdam de ervaring van velen: "Het is voor een verpleegkundige moeilijk om in een ziekenhuis harmonisch uit te groeien".

De wens om door empirisch onderzoek meer duidelijkheid te brengen op dit gebied gaf mij de impuls sociologie te gaan studeren. Tijdens deze studie heb ik afstand kunnen nemen van de emotionele betrokkenheid op bepaalde problemen. Ook brachten sociologische visies meer helderheid in oorspronkelijk voor mij duistere mechanismen. Anderzijds werden heilige huisjes ontmanteld; ik werd gedwongen afstand te nemen van vermeende zekerheden.

Uit dit proces kwamen gedachten en vragen naar voren. Enkele daarvan zijn:

- Vele hoofdverpleegkundigen, gediplomeerden en leerlingen kiezen hun beroep om humanitaire redenen. Wat is de oorzaak dat zij zo teleurgesteld hun beroep verlaten?

- Waarom kan de grootste groep werkers binnen het ziekenluuis - de verpleegkundigen - zo weinig invloed uitoefenen op de eigen werkomstandigheden? Waarom steunen verpleegkundigen elkaar zo weinig?

- Hoe is het te verklaren dat dáár, waar de status en prestige van verpleegkundigen hoog is, ook de verzorging van patiënten op hoog niveau staat?"

Om deze én andere vragen te kunnen beantwoorden leek mij een onderzoek naar de positie van hoofdverpleegkundigen het meest geschikt. Er zijn meerdere argumenten aan te voeren die pleiten voor het centraal stellen van de hoofdverpleegkundige. Enkele zijn:

- De hoofdverpleegkundige is op de ziekenafdeling de eerst-verantwoordelijke voor de patiëntenzorg. Als men de patièntenzorg wil verbeteren dient men na te gaan warom het afdelingshoofd de zieke geen optimale verzorging kan geven.

- De hoofdverpleegkundige neemt op de patiëntenafdeling een centrale plaats in. Door te zoeken naar haar werkspanningen kunnen wij ook gedragingen van andere groepen analyseren. Welke groepen of personen ondersteunen of belemmeren haar werk?

- De hoofdverpleegkundlige is de "klimaatarchitect" van de ziekenafdeling. Zij is de eerst-aangewezene om verbeteringen op de afdeling in te voeren.

- De Wolff heeft er eveneens toe bijgedragen de hoofdverpleegkundige in het onderzoek centraal te stellen. Door ervaringen die hijkreeg vanuit de industrie gaf 
hij het advies het onderzoek te baseren op het verpleegkundig middenkader in de ziekenhuizen. In de industrie zit het middenkader vaak knel. Hun problemenzijn niet zelden structureel verankerd. Als je kunt aantonen dat veel moeilijkheden silet ontstaan door persoonlijk falen van de hoofdverpleegkundige, ligt de weg open voor een goede en eerlijke discussie. Alleen dan kunnen problemen effectief worden aangepakt.

\section{Vraagstelling}

Bij het uitwerken van oorzaken en gevolgen van het verloop wees ik op twee cyclische processen. De eerste cyclus is: door verloop ontstaat personeelstekort en dat stimuleert op zijn beurt weer verloop. Het tweede cyclische proces verloopt via de psychische spanningen van verpleegkundigen. Hoofdverpleegkundigen zouden hiervoor te weinig aandacht hebben. Er onstaat een negatief beeld wan het beroep. Dat schrikt begaalde jonge mensen af om verpleegkundige te worden. Daardoor komt het verpleegkundig beroep op een lager niveau. Dat stimuleert verloop en zo ontstaan spanningen. Door het cyclisch verloop van deze processen is het onduidelijk wat oorzaak en wat gevolg is.

Omdat aan verloop vaak spanningen ten grondslag liggen of er uitvloeisel van zijn, lijkt een breed opgezet explorerend onderzoek hiernaar gewenst. Dit proefschrift poogt in de leemte te voorzien. De basis-vraagstelling voor in hoofdstuk 2 beschreven literatuuronderzoek is: Welke belemmeringen ontmoet de hoofdverpleegkindige bij de uiroefening van haar taak?

Deze probleemstelling zal na het literatuu ronderzoek in een aantal concretere vraagstellingen worden verdeeld.

\section{Opbouw van het onderzoek en indeling van het proefschrift}

Het project startte met een literatuuronderzoek over de positie van hoofdverpleegkundigen in algemene ziekenhuizen in Nederland. Dit werd afgesloten met het rapport: "Het rolconflict van de hoofdverpleegkundige", publicatie no. 4, Stressgroep Nijmegen, 1978.

Nadat van het Ministerie van Volksgezondheiden Milieuhygiëne in 1979 een subsidie werd verkregen voor de duur van $1 \frac{1}{2}$ jaar, kon het vooronderzoek beginnen. In het vooronderzoek participeerden 11 ziekenhuizen. Het vooronderzoek werd afgesloten met een interimrapport: "Interimrapport onderzoeksproject Stress bij hoofdverpleegkundigen", publicatie no. 18, Stressgroep Nijmegen, 1980.

Een aanvullende subsidie voor het hoofdonderzoek werd verstrekt door de Katholieke Universiteit te Nijmegen. Het vooronderzoek werd gehouden in 30 ziekenhuizen. Voor nadere toelichting, zie hoofdstuk 4 , methodische aspecten van het onderzoek. Deeerste verslaggeving van dit onderzoek geschiedde in het rapport: "De hoofdverpleegkundigen. Een onderzoek naar hun positie en problemen in de Nederlandse ziekenhuizen", publicatie no. 28, Stressgroep Nijmegen, 1981. In dit proefschrilt worden meerdere gegevens van het hoofdonderzoek uitgewerkt. Hoofdstuk 1 behandelt de aanleiding en voorbereiding van het onderzoek. 
In hoofdstuk 2 worden literatuurbevindingen weergegeven. Naar aanleiding van dit literatuuronderzock wordt in hoofdstuk 3 een aantal concrete vraagstellingen geformuleerd.

Hoofdstuk 4 handelt over de opzer van het onderzoek.

In deel 2, dat met hoofdstuk 5 begint, worden de onderzoeksbevindingen weergegeven. Hoofdstuk 5 handelt over de rolonduidelijkheid en taakonduidelijkheid van hoofdverpleegkundigen.

Hoofdstuk 6 bespreekt de rolonduidelijkheid van hoofdverpleegkundigen.

Hooldstuk 7 handelt over de ervaren rolonduidelijkheid en de reacties daarop.

In hoofdstuk 8 brengen wij enkele persoonlijkheidskenmerken en persoonsgebonden variabelen van hoofdverpleegkundigen in relatie met ervaren rolonduidelijk heid.

In hoofdstuk 9 gaan wij na hoe intermenselijke verhoudingen in verband staan met ervaren rolonduidelijkheid.

In hoofdstuk 10 geven wij een korte samenvatting en enig commentaar.

\section{Samenvatting}

Algemeen neemt men aan dat een hoog verlooppercentage een indicatie is voor een ongunstig arbeidsklimaat. Hoewel, waarschijnlijk onder invloed van toenemende werkloosheid, het verlooppercentage afneemt,zijn wijergeenszins van overtuigd dat daarmee ook de spanningen zijn verminderd. Misschien zelfs het tegendeel. Bij arbeidsonrust kan verloop een ventielfunctie hebben; wanneer werknemers geen mogelijkheid winden van baan te veranderen, kunnen spanningen vermeerderen. Een slechte werksfeer is niet alleen problematisch voor verpleegk undigen, matarook voor de patiëntenzorg en voor de maatschappij.

In de literatuur wordt een aantal oorzaken genoemd voor de slechte intermenselijke verhoudingen in ziekenhuizen. De Nationale Ziekenhuisraad te Utrecht wraagt om op korte termijn te beginnen met een uitgebreid onderzoek naar de oorzaken van de problemen in de verpleging.

Verschillende overwegingen leiden ertoe om in een dergelijk onderzoek de hoofdverpleegkundigen centraal te plaatsen, ondermeer om verbeteringen van patientenzorg te kunnen behartigen, om inzicht te krijgen in factoren die het werk van hoofdverpleegkundigen belemmeren, om de oorzaken van een minder gunstig arbeidsklimat te kunnen achterhalen en om de structurele werkproblemen van afdelingshoofden te verhelderen.

De leidende gedachte is dat de positie van hoofdverpleegkundigen het scharnierpunt is waarlangs verbeteringen kunnen worden aangebracht in de ziekenhuiswereld.

Daarwoor is allereerst nodig empirisch een duidelijk inzicht te verwerven in de problemen en spanningen die zij ervaren.

De globale probleemstelling richt zich daarom op de vraag welke belemmeringen hooldverpleegkundigen ervaren bij de uitoefening van hun functie. 


\section{Hoofdstuk 2}

\section{Literatuurbevindingen}

Dit hoofdstuk bevat een overzicht over de ontwikkeling van de verpleging en thet ziekenhuis, de organisatie van het ziekenhuis, de professionelen en hungedragingen, de ziekenafdeling, de hoofdverpleegkundigen, verpleegkundigen en patiënten. Alleen de elementen die kunnen bijdragen tot een beter inzicht in de structuur, werkwijzen, opvattingen en spanningen binnen het ziekenthuis, voorzover van belang voor het basisprobleem, de belemmeringen in de takuitoefening van de hoofdverpleegkundige, zullen ter sprake komen.

\subsection{De ontwikkeling van de verpleging en het ziekenhuis}

De problemen die men thans waarneemt komen, aldus Barness (1967), mede voort uit de historische ontwikkeling van verpleging en ziekenhuizen. Zij wijst als bronnen van de problemen op nu nog voortlevende traditionele opvattingen die ééns functioneel waren maar thans hun zin verloren hebben, maar ook het omgekeerde: ook nu nog als goed beoordeelde gewoonten, opvattingen en verwachtingen uit het verleden die echter verloren gingen.

Aan welke positieve en negatieve elementen wordt hierbij gedacht?

\section{Altruïsme}

Altruïsme - een belangrijk element van de Joodse en Christelijke religie - is de inspirator geweest voor de ziekenzorg. In de begintijd van het Christendom waren het met name vrouwen uit aanzienlijke families die zich - in hun paleizen en patriciërshuizen - om het lot van zieken bekommerden. Dat gaf ziekenverzorging als bezigheid een hoge status.

De basis van wat later het ziekenhtuis zou worden, is te vinden in de vanaf rond $300 \mathrm{n}$. Chr. aan kathedralen en kloosters verbonden "multifunctionele" tehuizen. Deze gelegenheden waren tegelijk hotel, weeshuis, bejaardentehuis en ook ziekenverblijf. De eerste werkers in deze tehuizen waren pastores en verpleegkundigen.

De invloed van de geneeskunde was in die tijd niet groot; religieuze en psychische aspecten kregen de meeste aandacht. De gastvrijheid en hartelijkheid was groot, patiënten waren geëerde gasten, die vaak in processie werden binnengehaald. Opname verliep vaak via de biechtstoel. Gastvrijheid was er ook voor de familicen voor de vrienden van de zieke gasten. Het gasthuishad de deuren de hele dag voor hen open. 


\section{Reglementering}

Op den duur werd de gastwrije atmosfeer misbruikt, zodat men regels moest gaan stellen. Toen kloosterlingen in de ziekenhuizen gingen werken bleken kloosterreglementen ook zeer geschikt voor ziekenhuisbewoners. De regels van de Benedictijnen werden in de vroege middeleeuwen in de ziekenhuizen toonaangevend.

De reglementering nam nog toe in de ziekenhuizen die langs de pelgrimswegen werden gebouwd, en die door ridder-verpleegorden werden geleid. Deze inrichtingen werden bekend om de straffe en efficiènte organisatie, waarin de militaire inwloed duidelijk merkbaar was.

Vanaf de lle eeuw nam de invloed van de kerk op de ziekenhuizenafen namen leken het bestuur over. Ook zij werden geinspireerd door ridderorden.

Rationaliteit ging het ziekenhuisteven overheersen. In de tijd van de grote epidemieën ging men iets vermoeden van de overdraagbaarheid van deze plagen, en $\mathrm{kwam}$ men op het idee zieken te isoleren van de rest van de samenleving. Vanaf de dertiende eeuw kenden de ziekenhuizen zgn. 'pestkamers'.

\section{Arts in ziekenhuis}

In de zestiende eeuw kwam langzamerhand de arts zijn werk binnen het ziekenhuis zoeken, Tot dan toe was dat uitsluitend het werkterrein van de pastor en de verpleegkundige geweest. Het begin van het optreden van de medicus in het ziekenhuis was niet zo geslaagd, ook omdat het ziekenhuis zelf in de periode van plm. 1650 tot 1850 een dieptepunt doormaakte. Alleen iemand die geen enkele uitweg meerzag liet zich opnemen.

De grote medische ontdekkingen in de achttiende, negentiende en twintigste eeuw makkten het voor zieken zinvol en later noodzakelijk om voor medische behandeling te worden opgenomen. De organisatie werd complexer, dure apparaten werden aangeschaft, de efficiëncy nam toe.

\section{Huidige tijd}

Wat is er van de historische ont wikkeling gebleven, wat ging verloren en wat vereiste aanpassing of aanvulling?

Het altruïsme, de medemenselijkheid, zal waarschijnlijk een goede basis blijven voor een hoogwaardige patiëntenzorg, maar kan niet meer als enige voorwaarde gelden. De wetenschappelijke vooruitgang in de geneeskunde dwingt de verpleegkunde tot een gelijk waardige groei.

De hoge status van verpleging is geleidelijk verd wenen. Hij bereikte een dieptepunt in de donkere jaren van ziekenverpleging (1650-1850).

De proble men werden overwonnen door een aantal factoren, waarvan als belangrijk genoemd mogen worden de mentaliteitsverbetering onder ziekenhuiswerkers (verpleeg.kundigen niet uitgezonderd) en goede verpleegstersopleidingen. Misschien zijn deze twee facetten opnieuw belangrijke pijlers voor positieve veranderingen in de patièntenzorg. 
In het ziekenhuis is de nadruk sterk komen te liggen op de somatische kant van de ziekte; de religieuze en psychische aspecten krijgen nauwelijks of in ieder geval veel minder aandacht, alhoewel rituelen zijn gebleven die haast religieuze dimensies hebben. Zo heeft de witte doktersstoet met de magisch-machtige uitstraling op de ziekenhuispatiënt een gelijkenis met de middeleeuwse ziekenhuisprocessie. De middeleeuwse gewoonte om zieken via de biechtstoel op te nemen, is verdwenen. In veel gevallen vervangt de polikliniek de biechtstoelfunctie. De (co)assistent die achter de witte kamerschermen fluisterend de eerste gegevens noteert, herinnert nauwelijks meer aan de grijze prelaat die eeuwen geleden ook de zieke ondervroeg, zij het over meer geestelijke zaken.

Hartelijk en gastvrij kan men nu de ziekenhuizen niet meer noemen. Ze zijn kil en steriel en lijken meer op quarantaineverblijven dan op patriciërspaleizen. Patienten leven ook nog steeds vrij geïsoleerd van de gewone samenleving, ook al hebben ze géén besmettelijke ziekte.

Reglementering in het ziekenhuis is gebleven, soms met voorschriften die in de huidige situatie niet altijd functioneel zijn.

In het moderne ziekenhuis richt de behandeling en verzorging van de patiënt zich soms meer naar de wetten en vereisten van de technische elementen uit de omgeving, dan naar de verwachtingen van de patiënt. Door deze ontwikkeling worden zieken en verpleegkundigen van een wezenlijk element in hum relatie beroofd: het persoonlijke aspect in de verzorging.

\section{Samenvatting}

De verzorging en behandeling van zieken is van een eenvoudige, menselijke benadering uitgegroeid tot een complexe wetenschappelijke aanpak. In deze ontwikkeling zijn twee belangrijke elementen te onderkennen.

Een wetenschappelijke aanpak, die niet begeleid wordt door humaan gerichte waarden en normen, is geen onverdeelde zegen voor de patiënt. De positieve krachten van de wetenschappelijke vooruitgang voor de patiëntenbehandeling worden ook deels te niet gedaan door een aantal maatschappelijke ont wikkelingen. Het tweede element ligt op het terrein van de verpleging. Men ziet dat verpleging historisch beschouwd - géén zijtak is van de geneeskunde. Geneeskunde en verpleegkunde hebben onathankelijke ontstaansbronnen. Eeuwenlang beoelenden artsen en verpleegkundigen hun beroepzonder noemenswaardig contact metelkaar. De werpleegkunde is uiteindelijk ondergeschikt geraakt aan de geneeskunde.

\subsection{De organisatie van het ziekenhuis}

Het eenvoudige, hierrarchisch opgebouwde ziekenhuis met de zg. lijnorganisatie (bevelen van boven naar beneden) kreeg een volkomen nieuwe structuur toen de medicus daar zijn werkplaats koos. De arts paste namelijk niet in het organisatorische schema. De directie accepteerde deze wetenschapper, die door zoveel opvallende successen van velen respect ontving. Maar toen hun aantal groter werd begonnen zij door hun vrije opstelling de orde en regelmat wan thet ziekenhuis 
aan te tassten. Het ziekenhuispersoneel ervoer de medici weliswaar als keien, maar dan als een soort zwerfkeien, die ongeorganiseerd rolden en samenschoolden, waardoor de organisatie op totaal onverwachte momenten uit zijn evenwicht raakte. De organisatie werd een probleem. Waarom? Hoe loste zich dat op?

\section{Professioneel/bureaucratisch model}

Het ziekenhuis ontwikkelde naast het hiërarchisch bestuur een tweede gezagselement: dat wan de artsen (de professionals) ofwel de staf-organisatie. De literatuur noemt het ziekenhuis hét prototype van een organisatie met een "dual management". Hierbij krijgt een ondergeschikte twee meerderen, nl. een hiërarchische chef (uit de lijnhiërarchie) en een functionele chef (uit de staforganisatie). Volgens vele auteurs is dit een bron van spanningen. De bureaucraat en de professional zouden - volgens hen - tegengestelde opdrachten geven. Hierdoor kunnen werkers in onoplosbare conflicten komen.

Wat dat professioneel/bureaucratisch conflict nu precies inhoudt is soms niet duidelijk.

De verwarring begint bij de omschrijving van de begrippen "professionalisatie" en

"bureaucratie" "Daarvan zijn verschillende definities in omloop.

Om onduidelijkheid te voorkomen, willen wij aangeven dat wij ons baseren op de omschrijvingen van Hall (1969):

\section{Professionalisatie}

Het gedrag van de professional wordt gekenmerkt door:

- geloof in eigen dienstbaarheid aan het publiek;

- gevoel van roeping en toewijding aan het werkterrein;

- gebruik van de beroepsvereniging als referentiekader;

- geloof in zelf-regulatie binnen het beroep;

- gevoel dat hij vrij moet zijn van externe druk (autonomie).

\section{Bureaucratie}

De bureaucratische organisatie kenmerkı zich door:

- een hiërarchische gezagsstructuur;

- arbeidsverdeling; iedere functionaris heeft een beperkte bevoegdheid;

- het bestuur berust op formele regels;

- regels worden zonder aanzien des persoons toegepast;

- men baseert zich op rationele, gespecialiseerde deskundigheid;

- recrutering en promotie van functionarissen vindt plaats op grond van kennis, kunde en prestaties.

In bovenstaande omschrijving komt als eerste essentiële punt naar voren dat de professional zich oriënteert op de patiënt/cliënt, terwijl de bureaucraat primair als doel heeft het soepel functioneren van de organisatie.

Volgens de professioneel/bureaucratische conflicttheorie zouden deze twee verschillende uitgangspunten tot spanningen leiden. 


\section{Fictief probleem}

Nuchtere ziekenhuiswerkers die in de literatuur over hun problemen lezen ontkennen dat in het bovenbeschreven conflictmodel de essentie van hun spanningen ligt. $\mathrm{Zij}$ vinden dat een conflict in principe geen ramp hoeft te zijn. Integendeel. Het is vaak een teken van levendigheid en actie. De professional en de bureaucraat komen ieder voor de patiènt op, zij het langs andere wegen. Conflicten tussen hen zijn vaak functioneel. De professional wordt daardoor geconfronteerd met de mogelijkheden en beperkingen van de organisatie en de bureaucraat met de noodzakelijkheid van souplesse om aan verwachtingen van de arts te voldoen.

Wat is er dan in feite aan de hand? Waarom klagen professionals en bureaucraten over elkaar? Wat is er mis met de organisatie? Waarom zeggen hoofdwerpleegkundigen dat zij binnen die structuren niet kunnen werken? Wij zullen in de historie teruggaan.

\section{Verkokering}

Toen in de negentiende eeuw de medische wetenschap zich uitbreidde, had dit gevolgen voor het ziekenhuis. Onder invloed van de professionele ontwikkeling ontstonden niet alleen allerlei soorten specialismen, maa ook diensten als laboratoria, röntgenafdeling, onderzoeks- en diagnostische diensten, apotheek, fysiotherapie, arbeidstherapie e.d. Deze diensten staan los van elkaar, als kokers of aparte cellen. Het ziekenhuis lijkt thans op een honingraat. De kokers of cellen zijn nevengeschikt en hiërarchisch opgebouwd. Alleen de directie heeft formeel tot alle kokers toegang.

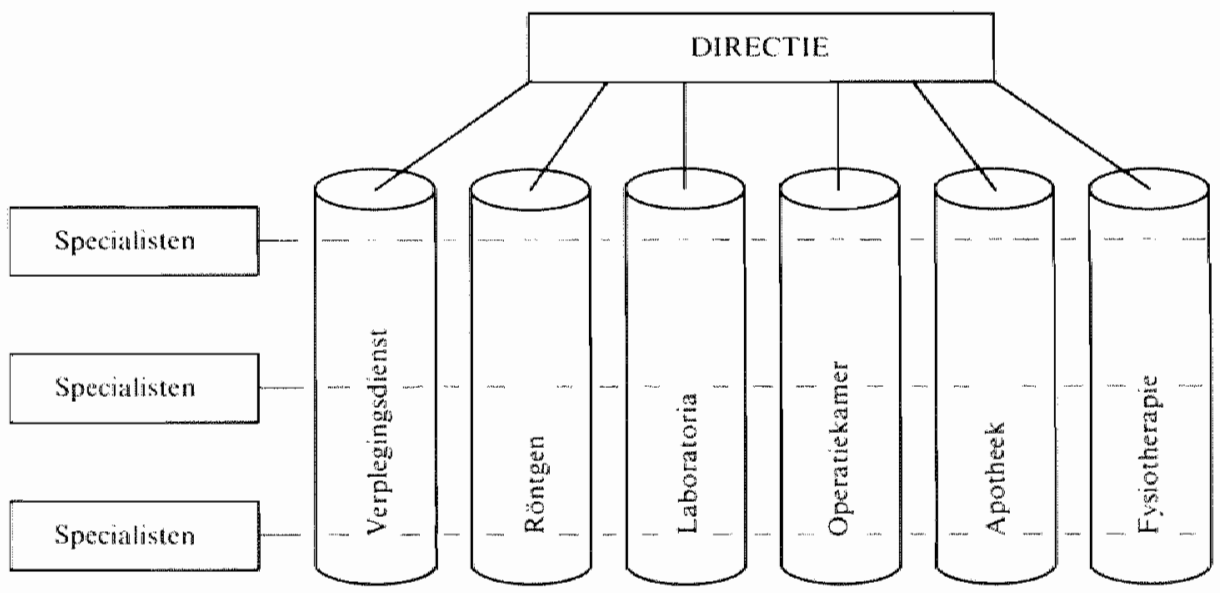

Figur 1. Overzicht wan een aantal functionele diensten van het ziekenhuis (er zijn slechus enkele genoemd).

De specialisten hebben of nemen als staf-functionaris echter speciale voorrechten. Daardoor zijn zij in staat door de kokerwanden heen te breken en voorschriften te negeren. 
De verplegenden, met name de hoofdverpleegkundigen, in éen van die kokers opgesloten, missen echter die mogelijk heden van de medicus, terwijl zij die woor een goede taakuitoefening vaak wel nodig zouden hebben. Daar beginnen de grote problemen van hoofdverpleegkundigen. Als de woornaamste daarvan worden hier besproken: coördinatieproblemen, vorming van groepen met een in- en outgroupmentaliteit, vorming van informele netwerken die afwijken van formele organisatiestructuren en de macht van specialisten.

\section{Coördinatieproblemen}

Als de arts delegeert aan de verpleging houdt dat in, dat de hoofdwerpleegkundige allerlei werkzaamheden moet coördineren, allerlei kokers moet inschakelen: röntgen, Jaboratoria, a potheek, operatiekamer, e.e.g., e.c.g., keuken, fysiothera pie, maatschappelijk werk, etc. Zij mist echter het prestige van de staffunctionaris en de opdrach tbevoegdheid van directie of diensthoofden. In het kort: voor bevelvoering zit zij te laag en stafwoorrechten heeft zij niet.

Verweij zegt daarover:

"Vele activiteiten worden op een hoger niveau dan de verpleegafdelingen gecoördineerd. Het hoofd van de verpleegafdeling is verantwoordelijk voor de goede gang van zaken op de verpleega fdeling. Hij heefteen sterk coördinerende taak met echter weinig formele beslissingsbevoegdheden. De geringe zeggenschap op het niveau van de verpleegafdeling is een gevolg wan de structurele kenmerken van de organisatie.

De formele beslissingsbevoegdheid inzake de coördinatie en integratie met imbegrip van het beheer liggen in de functiegerichte organisatie van het ziekenhuis op een hoog niveau: bij diensthoofden en directie."

Beslissingsbevoegdheden die hoofdverpleegkundigen dienen te bezitten, maar in feite vaak missen zijn o.a.: medezeggenschap in het personeelsbeleid, medezeggenschap in het opname- en ontslagbeleid van patiënten, medezeggenschap over verdeling van de financiële middelen van het ziekenhuis, en medezeggenschap over (beperkende) maatregelen die verschillende ziekenhuisdiensten opstellen.

\section{In- en outgroup}

De kokers isoleren zich van elkaar. Iedere discipline ontwikkelt een eigen groepscultuur, gewoonten, meningen en gedragingen. Ook de verplegingsdienst doet dit. Het ziekenhuis is zo een conglomeraat van groepen die elkaar niet meer begrijpen en waarderen.

Niet alleen de verplegingsdienst, allerlei groepen klagen over isolatie en gebrekkige samenwerking. Emanuel-Vink (1981) die problemen rond het ontslag van patienten uit ziekenhuizen onderzocht, wijst bijvoorbeeld op de geïsoleerde positie van de maatschappelijk werker. Zij zegt:

"De functie van het ziekenhuis-maatschappelijk werk dient beter te worden geprofileerd en dient meer functioneel te worden ingepast in de opname- en ontslag-procedure." 


\section{Informele netwerken}

Er ontstaan informele netwerken die sterk afwijken van de formele organisa tiestructuur. Goffman (1963) wijst daarop als hij spreekt over de officieuze kant, of zoals hij zegt "de onderkant van de organisatie". Deze structuren ontwikkelen zich vooral in de bedrijven waar werkers zich niet aan (kunnen) passen aan de formele instructies. $\mathrm{Zij}$ die in de organisatie de meeste macht hebben, hebben de grootste kans de regels onzichtbaar naar hun goeddunken te ploo"en. In het ziekenhuis weven zij vangnetten voor kwetsbare leerlingen die na twee of drie stagewisselingen overstuur en gedesillusioneerd het beroep verlaten. Het moeten voldoen aan onzichtbare verwachtingen die op iedere afdeling weer anders liggen en nergens duidelijk worden omschreven, is de oorzaak van veel spanningen en verloop onder de minst weerbaren. Hoofdverpleegkundigen die toch door ervaring weten was voetangels en klemmen kunnen liggen, worden ook nog regelmatig geconfronteerd met onzichtbare structuren die recht-toe-recht-aan werken belemmeren. De boosheid waarmede zij voorbeelden aanhalen geeft ons het gevoel dat "wildrooster" nog een betere term is dan "vangnet".

\section{Macht specialisten}

In ondubbelzinnige taal wordt in de literatuur de dominantie van de professionals aan de orde gestell. Zie bv. Freidson (1970):

"Het huidige systeem van de georganiseerde gezond heidszorg berust teveel op de dominantie van de medische autoriteit."

Ook Vollebergh (1976) schrijft over de op specialisten en specialisme gebaseerde macht.

Strauss (1963) die onderzoek verrichtte in Amerikaanse ziekenhuizen, spreekt zelfs over machtsmisbruik door artsen. Niet zelden komen en gaan medici naar eigen goeddunken en houden geen rekening met de eisen van een organisatie zoals berekenbaarheid en het zich houden aan afspraken of, indien een afspraak nakomen niet mogelijk is, het doorgeven wan een bericht van verhindering.

Ampe (1970) wijst op de hogere positie van de arts en het gemak waarmede hij daardoor informatie kan doorgeven of achterhouden. Deze machtsfactor is van grote betekenis in die gevallen waarbij hij de situatie in eigen woordeel wil manipuleren.

Zo nu en dan proberen specialisten op terreinen waar zij als medicus geen macht hebben, toch invloed uit te oefenen. Een ziekenhuisdirecteur zei "De chirurg wil een vinger in de pap hebben bij de aanstelling van een hoofdverpleegkundige. Omgekeerd claimen de hoofdverpleegkundigen geen inspraak bij de aanstelling van een specialist".

Figuur I (op blz. 19) is dus in veel gevallen een theoretisch model. Het empirisch model is als volgt: 


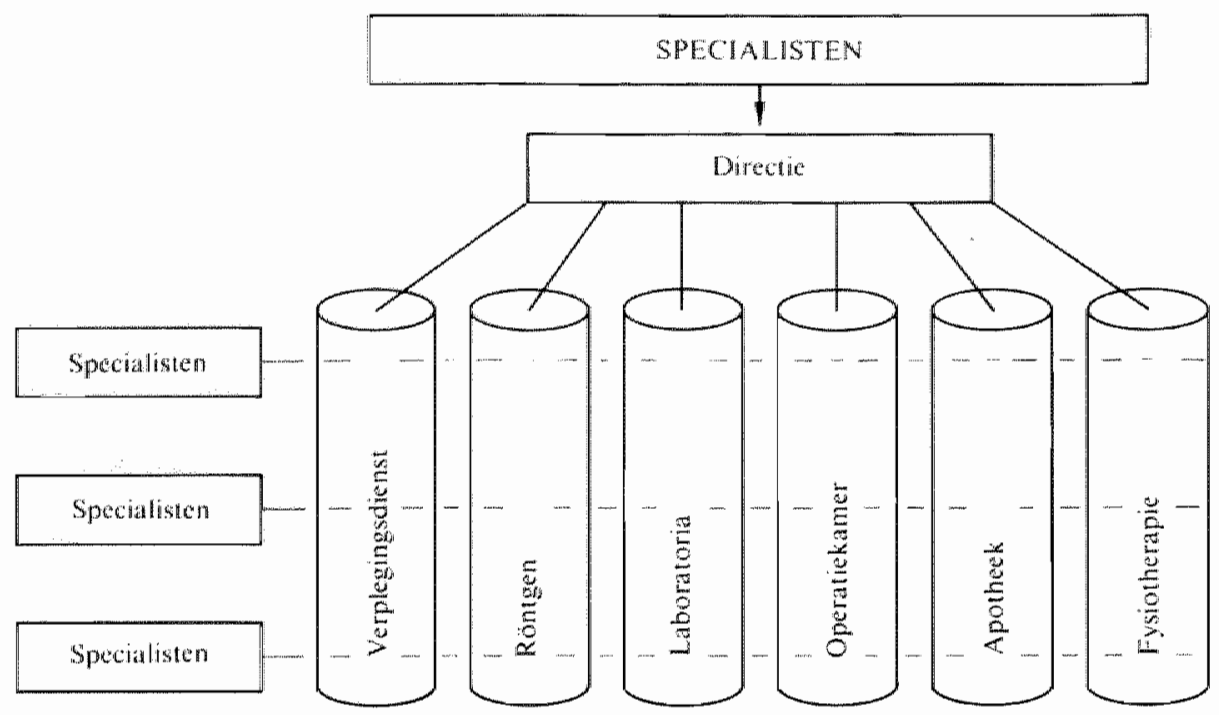

Figur 2. Gezagsmodel, zoals in feite in veel ziekenhuizen wordt aangetroffen.

Wij zijn tot de overtuiging gekomen dat de essentie wan de spanningen in ziekenhuizen niet te verklaren is met behulp van de professioneel/bureaucratische conflicttheorie. Het probleem zit hem in de botsing van twee soms tegengestelde bevelslijnen, maar in het feit dat de medische staf zich boven de hiërarchie heeft geplaatst, maar zich niet houdt aan een aantal spelregels die in een bureaucratie gebruikelijk zijn.

Uit vele conflicten zullen wij één voorbeeld aanhalen. Een verpleegkundig directeur van een klein ziekenhuis vertelde ons het volgende:

"Enkele dagen voor Kerstmis deelden hoofdverpleegkundigen mij mede dat voor de feestdagen te weinig personeel aanwezig was. Ik vergeleek het aantal personeelsleden en patiënten en zag dat hun klachten juist waren. Ik ben naar verschillende specialisten gegaan en vroeg hun of zij voor de feestdagen nog patiënten zouden ontslaan. Geen enkele specialist was bereid mij iets van zijn plannen mede te delen.

Onmiddellijk belde ik daarom naar alle kanten om bulp. Uitzendkrachten, parttimers, jonggehuwden die pas het beroep verlaten hadden, iedereen werd aangeklampt.

Een dag voor Kerstmis stond de reserve-ploeg klaar. Hun salaris betekende een financiële aderlating voor het ziekenhuis. Op diezelfde dag ontsloegen de specialisten vijftig patiënten. Hierdoor werd het reserve-personeel overbodig. Wij moesten hen wel uitbetalen. Belangrijke andere projecten voor het welzijn van patiènten konden niet meer doorgaan."

Green (1975) die gedurende twee jaren in drie ziekenhuizen onderzoek verrichtte komt tot de uitspraak dat de essentie van de spanningen in ziekenhuizen niet te verklaren is door professioneel/bureaucratische conflicttheorie: "Het ziekenhuis is 
geen onafhankelijke werkgever meer. Soms integendeel. Het bedrijf wordt steeds méér afhankelijk van medisch specialisten. Zij leggen nl. door hun opname- en ontslagbeleid de financiële basis. Door deze macht hebben de specialisten een groot overwicht, zowel op de ziekenhuisdirecties alsook op instellingen die het beleid in de gezondheidszorg bepalen".

De hoofdverpleegkundigen staan clws niet onder twee verschillende bevelslijnen; de professionele en de bureaucratische, maar werken in een in elkaar verstrengelde belangenstructuur met de medici aan de top.

Tussen medici en directie bestaan uiteraard wel conflicten. Die leiden er soms toe dat aan het middenkader - verpleegkundigen - tegengestelde opdrachten worden gegeven (waarvan dadelijk een voorbeeld). Maar daarin schuilt niet de kern van de problematiek van de hoofdverpleegkundige. Die moet veeleer gezocht worden in het conflicteren van de belangen van het ziekenhuis in het algemeen met die van de patiënten en het verpleegkundig beroep. Dit uit zich bv, in de opname-problemen.

\section{Directie}

In deze paragraaf over de organisatie van het ziekenhuis willen we het na de bespreking van de gevolgen van de verhouding directie/specialisten voor de hoofdverpleegkundigen hebben over de spanningen tussen directie en hoofdverpleegkundigen alvorens in de volgende paragraaf gedetailleerd in te gaan op de verhouding tussen specialisten en hoofdverpleegkundigen.

De klachten die (hoofd)verpleegkundigen over de directie uiten betreflen voornamelijk:

- het personeelsbeleid;

- hett ondersteunend beleid;

- inspraak.

Directie

Specialisten
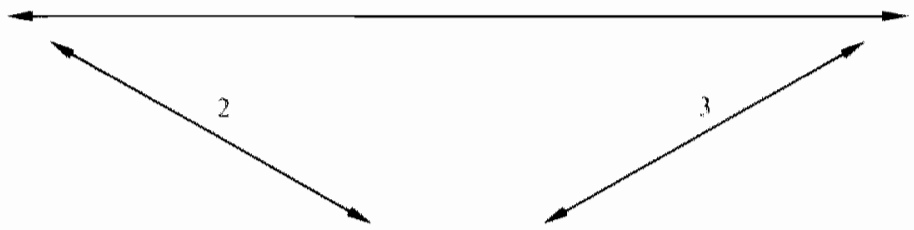

Hoofdverpleegkundigen

Figur 3. Lijn 1, spanningen fussen directie en specialisten. Lijn 2 spanningen tussen directie en hoofdverpleegkundigen. Lijn 3 spanningen tussen specialisten en hoofdverpleegkundigen.

\section{Personeelsbeleid}

Galdwell en Weiner (1981) komen na een uitgebreid literatuuronderzoek tot de conclusie dat de meeste stress van verpleegkundigen ligt in overmatige werkbelasting en personeelstekorten.

Op blz. 33 wordt beschreven hoe deze problemen zijngegroeid. Daa ruit blijkt onder- 
meer dat ziekenhuisdirecties niet altijd in staat zijn de klachten over personeelstekorten krachtdadig op te vangen. Maar ondanks beperkende maatregelen blijft er altijd wel een bepaalde marge, waarbinnen hulp mogelijk is.

Hoofdverpleegkundigen hebben niet altijd het gevoel dat alle mogelijkheden worden benut om hen te helpen. Hierdoor ontstaan wrijvingen tussen directieleden en afdelingshoofden.

Gonggrijp (1982) schrijft:

"De werkmieren (verpleegkundigen) raken steeds meer uitgeput. Dag van de verpleging wordt explosief. Ziekenhuisstaven pikken het niet meer.

De ziekenhuisdirecties en besturen schreeuwen nu ook moord en brand, onder andere via de Nationale Ziekenhuisraad. Maar ze hebben zelf boter op hun hoofd: in de decennia van de ongebreidelde groei, toen het éne grote ziekenhuis na het andere werd opgetrokken, waren de professionalisering en de modemere organisatie van de verpleegkunde óók het stielkind."

Het opvoeren van het bedbezettingspercentage heeft voor ziekenhuis én specialist aantrekkelijke kanten. Niet zelden zijn patiënten en verpleegkundigen hiervan de dupe. Een hoofdverpleegkundige zei:

"De patiènt wordt vaak veel te vroeg voor de operatie opgenomen. De chirurg wil de bedden vol hebben. Door zo'n lange lege wachttijd gaat de zieke zich veel te veel onnodige angsten maken."

Onderzoekingen (Williams 1979) wijzen uit dat hoe langer de patiënt vóór de operatie wordt opgenomen, hoe méér post-operatieve complicaties kunnen ontstaan.

Op andere punten, waar de belangen van directie en specialisten divergeren, wordt de hoofdverpleegkundige geconfronteerd met tegengestelde verwachtingen die soms in eisen en bevelen overgaan. Een afdelingshoofd vertelt:

"In dit ziekenhuis is een ongeluk gebeurd met een medische behandeling die door een verpleegkundige is verricht. Geluk kig is dit buiten de pers gebleven. Sindsdien heeft de directie ons verboden om welke medische behandeling dan ook te verrichten, óók als de specialisten daarvoor opdracht geven. De directie heeft die maatregel niet via de specialisten kunnen doordrukken, want die wensen de bestaande situatie te handhaven. Nu speelt de directie rechtstreeks op ons. Wij worden met ontslag bedreigd als wij aan de opdrachten van de specialisten gehoor geven." "Hoe samen te slagen zonder samen slaags te raken" zucht verpleegkundige Cornelissen (1974) in een scriptie.

Het elkaar steunen en bestrijden van specialisten en directie doorkruist een rustig en consistent beleid. Het is voor de directie daarom soms moeilijk een goede vertrouwensrelatie met hoofdverpleegkundigen op te bouwen.

In het vooronderzoek zei een verpleegkundig directrice dat, hoe verdeeld de specialisten onderling ook zijn, zij tegen de directic eén groep vormen en de verpleegkundigen handig met zich mee weten te manoeuvreren.

In dit ambivalente proces worden soms irrationele beslissingen genomen.

Ook het promotiebeleid wordt in de literatuur als een voorbeeld van een falend 
directiebeleid aangehaald. Bij gebrek aan ontplooiingskansen vertrek ken begaafde verpleegkundigen óf zij worden cynisch.

White (1980) zegt:

"'Andere beroepen tonen groei in geldelijke beloning, prestige, macht, rechten en verantwoordelijkheden, terwijl voor verpleegkundigen practisch geen veranderingen zijn opgetreden. Het lage zelfbeeld wat zij daardoor ontwikkelen draagt bij tot hardmekkige en moeilijk oplosbare intraprofessionele conflicten."

Het ontbreken van klinische carrière-mogelijkheden voor verpleegkundigen is echter ook voor iedere ziekenhuisdirectie een probleem.

Pannell (1982) zegt daarover:

"Verpleegkundigen die zich aangetrokken voelen tot een professionele carrière.

maar daarin tegenwerking ondervinden door de traditionele hiërarchische structuur, of door verouderde opvattingen, verliezen hun interesse in het werk en gaan elders werk zoeken."

Hij schrijft het verpleegkundigenverloop toe aan verouderde structuren wala rbinnen verpleegkundigen hun vleugels niet kunnen uitslaan.

Ford (1982) zegt:

"Verpleegkundigen willen patienten verplegen en geen systemen."

\section{Het ondersteunend beleid}

Kernaghan (1982) analyseert in een artikel problemen die aanleiding geven tot het massaal verloop onder verpleegkundigen. Gebrek aan ondersteuning door de directie noemt zij de fundamentele oorzaak van het verpleegkundigenverloop. In het artikel komen verschillende verpleegkundigen aan het woord. Zij zeggen ondermeer:

"Dit verloop onder verpleegkundigen zal niet ophouden totdat wij in staat worden gesteld om onze eigen beslissingen te nemen over ons werk en werkcondities."

Een chirurgische verpleegkundige die een Master's degree bezit zei dat de tien jaar in de verpleging voor haar "te lang" zijn. "Gebrek aan respect en ondersteuning door de directie is de voornaamste factor waardoor ik uiteindelijk de verpleging de rug toekeerde", zei een andere verpleegkundige met een zevenjarigeervaring. "De stress is overweldigend wanneer je als verpleegkundige de zieke hoog-gekwalificeerde zorg wilt geven", zei een derde verpleegkundige die het grootste gedeelte van haar zevenjarige praktijk op de chirurgische intensive-ca re doorbracht. "Dit komt omdat onze herhaalde verzoeken om verbeteringen aan te brengen in werksituaties die het leven van patiënten bedreigen, door de directie worden genegeerd. $\mathrm{Zij}$ negeren mijn frustraties en boosheid over het afdelingshoofd dat gemakshalve van de afdeling verdwijnt, iedere keer als er een hartstilstand is. Zij doen niets aan mijn klachten die ik maand na maand spui over gebrekkig trainingsmateriaal. Zij weigeren stafvergaderingen te houden. Onlangs kreeg ik nogeen reprimande van een directielid. $\mathrm{Zij}$ zei dat ik haar nodeloos werk bezorgde met mijn klachten over een incompetente verpleeghulp en over artsen die urenlang niet op komen dagen."

\section{Inspraak}

Op blz. 19 werd gesproken over de verkokering van het ziekenhuis en de problemen 
die daardoor voor hoofdverpleegkundigen ontstaan. Ondersteunende ziekenhuisdiensten (laboratoria, apotheek, keuken e.d.) stellen soms reglementen op die het werk van hoofdverpleegkundigen belemmeren of onmogelijk maken. Als een apotheek voorschrijft dat medicijnaanvragen 'sochtends vóót 10 uur binnen moeten $z i j n$, dan betekent een spoedopname van een patiënt - bv. 's middags om drie uur - en een zo snel mogelijke verstrekking wan effectieve medicignen een organisatorisch gevecht van de hoofdverpleegkundige.

Verantwoordelijkheden aanvaarden voor een goede patiëntenzorg dient samen te gaan met zeggenschap over ondersteunende diensten. Maar in veel ziekenhuizem hebben hoofdverpleegkundigen geen stem in deze - zich steeds méér autonoom opstellende - afdelingen.

Ook ontbreekt het veel hoofdverpleegkundigen aan inzage in - laat staan inspraak over - de financiële aangelegenheden van de eigen ziekenafdeling. In persoonlijke contacten zeggen sommige hoofdverpleegkundigen dat aanschaf van verpleegkundige artikelen wordt beperkt om aan financiële wensen van andere disciplines te kunnen voldoen.

\section{Samenvatting}

De twee gezagselementen in het ziekenhuis: de hiërarchische en de professionele, functioneerden oorspronkelijk naast elkaar, later tegen elkaar en thans voornamelijk onder elkaar. Dit is te vertalen in: samenwerking(naast), tegenwerking(tegen)en dominerende werking (onder). De professionals hebben de hoogste posities, maar zijn officieel daartoe niet aangesteld. Een netwerk van informele relaties en voorschriften is hiervan het gevolg. Conflicten zijn de logische consequenties van deze onduidelijke structuren. Deze zijn echter niet te herleiden tot het klassieke professioneel/bureaucratische conflict.

Coördinatieproblemen, in- en outgroup-mentaliteit, vorming van informele netwerken en de macht van specialisten, zijn enkele van de vele problemen waar de hoofdverpleegkundige mee te maken heeft. De directie verzuimt of is niet in staat de grootste groep werkers in het ziekenhuis, de verpleegkundigen, voldoende ontplooiingsruimte te geven. De clominantie van bepaalde groepen wordt door hen niet aangepakt.

\subsection{Specialisten en hoofdverpleegkundigen}

Op blz. 23 schreven wij over de verhouding tussen directie en hoofdverpleegkundigen (lijn 2) en de spanningen die tussen hen kunnen ontstaan wanneer aan bepaalde voorwaarden niet wordt voldaan.

In deze paragraaf komt aan de orde: wat zegt de literatuur over de verhouding specialist - hoofdverpleegkundige (lijn 3 )?

Vooral twee onderwerpen keren herhaaldelijk terug. Dat zijn: rolafbakening tussen geneeskundigen en verpleegkundigen, en spanningen in hun samenwerking. 


\section{Rollafbakeming}

"De samenwerking van arts en verpleegkundige is een probleem van drie moeilijke mensen: de patiënt, de verpleegkundigeen de arts", schrijft de medicus Van der Kroef (1970). Die moeilijke aard kan één van de redenen zijn van de conflicten over de rolafbakening tussen beide groepen: de nodige soepelheid in het geven en nemen ontbreekt.

Als dan één van beide partijen aanspraken maakt op het werk van de ander, of ongevraagd delegeert, zijn conflicten soms onvermijdelijk.

$\mathrm{Na}$ een onderzoek concludeert Cassee (1968) dat hoofdverplecgkundigen van mening zijn dat zij een zekere bevoegdheid hebben op medisch terrein, doch dat artsen deze mening niet met hen delen. Uit recente ziekenhuisliteratuur blijkt echter dat verpleegkundigen juist bezwaren maken tegen de toenemende druk van geneeskundigen om medische handelingen aan hen over te dragen. Deze zg. autorisatie (machtiging, verlening van bevoegdheid) geeft veel problemen in ziekenhuizen. Op blz. 24 wezen wij daar op. "Autorisatie: een fopspeen", aldus Lansink en Willemse (1981). Zij waarschuwen voor de gevaren van medisch handelen door verpleegkundigen. Onder autorisatie verstaan zij: de schriftelijke verklaring van een geneeskundige waarmede hij een verpleegkundige bekwaam verklaart bepaalde geneeskundige uitwoeringshandelingen te verrichten, mits aan bepaalde eisen qua deskundigheid wordt voldaan.

De autorisatie heeft alleen betrekking op de bevoegdheid. Verpleegkundigen zijn door zo'n verklaring echter niet gevrijwaard voor juridische aansprakelijkheid. Integendeel, de juridische aansprakelijkheid wordt groter.

De autorisatieproblematiek is moeilijk aan te kaarten. Een afdelingshoofd meldt dat de specialisten weg lopen als je daarover begint.

Anderzijds leven er bij de verpleegkundigen klachten over de bemoeienis van medici met het verpleegkundig werk.

Uit de literatuur (Kramer 1974, Murrel 1978, Redfern 1981) komt naar voren dat rolafbakeningsproblemen rolonduidelijkheid bij (hoofd)verpleegkundigen veroorzaken. Rolonduidelijkheid roept gebrek aan zelfachting op, vermindert de arbeidsvoldoening, veroorzaakt agressiviteit en bevordert uiteindelijk verloop van personeel.

\section{Samenwerking}

In de literatuur wordt gesproken over een superioriteitsgevoel van de medicus t.a.v. andere ziekenhuiswerkers. Artsen twijfelen aan de deskundigheid van andere functionarissen.

Freidson (1970) zegt daarover:

"De professionele trots brengt de werker ertoe zichzelf te beschouwen als totaal verschillend van de anderen en inderdaad superieur aan andere groepen. Deze postgevatte mening loopt lijnrecht uit op een achterdochtige houding t.a.v. de kundigheid van andere werkers - niet-professionals - waarover hij geen zeggenschap heeft. En zo komt de professional ertoe dammen op te werpen waarachter hij 
en zijn clienten veilig zijn tegenover al diegenen waarover hij geen jurisdictie kan uitoefenen."

Samenwerking tussen medici en andere disciplines op de ziekenafdeling is moelijk. Als men gat specialiseren heeft dat vaak tot ge volg dat men geen oog meer heeft voor de warde van bijdragen uit andere disciplines. Hun rationeel-wetenschappelije anpak is echter maar beperkt toepasbaar, aldus Lenrow en Cowdon (1980), die pleiten voor inbreng vanuit verschillende gezichtshoeken.

"Professionals en leken veronderstellen dat jeder probleem, mits juist en wetenschappelijk aangepakt, opgelost kan worden en wel in die zin dat het nooit meer terugkomt. Deze mening loopt uit in een bittere desillusie. Het leven presenteert problemen die op rationeel-wetenschappelijke wijze niet op te lossen zijn. Bijwoorbeeld conflicten en spanningen veroorzaakt door personen of ongeving."

Volgens Lentrow onderschatten wetenschappers de kracht van niet-rationele factoren, zoals religie en kunst. Vanuit religie en kunst kunnen bepaalde sociale problemen beter begrepen en opgelost worden dan door een rationele aanpak. Logica en afstandelijkheid zijn maar beperkt bruikbaar bij aanvoelen en oplossen van menselijke problemen.

Barness (1967) Jaat weimig heel van de samenwerkingsillusie tussen artsen en verpleegkundigen. Zij schrijf:

"Er schijnen maar weinig artsen en ander medisch personeel te zijn die een duidelijk idee hebben van de druk waaronder de hoofdzuster leeft; ieder streeft slechts zijn eigen speciaal doel na en neemt als vanzelfsprekend aan dat zij de maatregelen zal nemen die dat mogelijk maken. Zelden schijnt haar werkdag tot haar eigen tevredenheid te eindigen. De zaal schijnt als het ware de "arena" te zijn waar de behoeften en verwachtingen van iedereen, patiënten en personeelsleden, tezamen komen, wat soms met botsingen gepaard gaat.

Gedurende een discussie van een groep van experts werd de mening nar voren gebracht dat er soms een soort psychologische strijd schijnt te worden gevoerd tussen de hoofdzusteren haarverpleegstersbataljon en de dienstdoende arts en zijn volgelingen."

\section{Samenvatting}

De ontwikkelling van de geneeskunde is een belangrijk proces in de maatschappijen ziekenhuzen. De gevolgen van de steeds belangrijker wordende geneeskunde werden niet tijdig in het ziekenhuis onderkend en opgevangen. Daardoor zijn o.a. problemen ontstaan in de samenwerking tussen artsen en verpleegkundigen; de afbakening van hun rollen is soms onduidelijk. Dat blijkt bijvoorbeeld bij het delegeren van medische handelingen aan verpleegkundigen. Hierover bestaat weinig onderlinge eenstemmigheid.

Rolafbakeningsproblemen veroorzaken bij verpleegkundigen rolonduidelijkheid en vermindering van zelfachting, agressie en verloop. Spanningen in de rolafbakening geven ook moeilijkheden in de onderlinge samenwerking. Bovendien hebben 
degenen die zich specialiseren soms te weinig inzicht in en waardering voor de mogelijkheden van andere personen en disciplines. Zo kunnen conflicten ontstaan die het verloop onder verpleegkundigen bevorderen. Samenwerking tussen medici en verpleegkundigen en leren van elkaars benadering is echter een vereiste, niet alleen voor een goede patiëntenzorg, maa r ook voor de ontwik keling van beider beroepen.

\subsection{De ziekenafdeling}

Alvorens we in de volgende paragraaf concreet ingaan op de taak van de hoofdverpleegkundige lijkt het zinvol eerst nog een schets te geven van de werkomgeving op de ziekenafdeling. Daar speelt zich in de dagelijkse praktijk af wat in het voorgaande als algemene problematiek is aangeduid.

De ziekenhuisafdeling kent niet alleen een component van menselijke relaties en structuren, maar bestaat ook uit de gebouwde omgeving. Hippocrates zag de heilzame werking van rust en ontspanning; hij liet fonteinen bouwen in het ziekenhuis. In de Middeleeuwen waren de gasthuizen van paleisachtige allure, met prachtige wandschildering opdat kunst de patiënt troost kon brengen.

De ontdekkingen van Pasteur en Lister in de $19 \mathrm{e}$ eeuw maakten duidelijk dat er bacteriën bestonden en om hun gevaar te keren nam men ook in de gebouwen tegenmaatregelen. Het ziekenhuis, de ziekenafdeling, werden teruggebracht tot het strikt noodzakelijke en wat overbleef was af wasbaar en ontsmetbaar. Kille, steriele, haast vijandige ziekenverblijven, zo werden de ziekenhuizen vanaf het begin van de $20 \mathrm{e}$ eeuw. Niet alleen de patiënt, ook de verpleegkundige die dagelijks, jaar in jaar uit hierin verblijft, komt in deze omgeving te kort.

Niet alleen het interieurwerd aangetast. Ook andere zaken veranderden, zoalseerder werd aangeduid: de zelfstandige functie van verpleegkundigen, de leiding van de afdeling, de inspraak over personeelsbezetting, inzichten over de fina nciële armslag van de afdeling. Het hoofd van de ziekenafdeling, de hoofdverpleegkundige, verantwoordelijk voor de directe patiëntenzorg, heeft soms weinig invloed op besluiten die de afdeling direct raken.

Uit de literatuur blijkt dat op het niveau van de ziekenafdeling de volgende dric punten vooral problematisch zijn: het leiderschap op de afdeling (leiding over verpleegkundigen; harmonie met andere groepen; integratie), de personeelsbezettingen de intermenselijke verhoudingen (relatie tot de arts; erkenning van verpleegkundigen; promotiemogelijkheden).

Deze punten hangen voor een deel onderling nauw samen.

\section{Leiderschap op de afdeling}

De leiding over de afdeling is een van de belangrijkste taken van hoofdverpleegkundigen. Jacobi (1977) zegt wat zij van die leiding verwacht:

"Het directe doel van de verpleegkundige leiding moet zijn het bundelen van ver- 
pleegkundige krachten teneinde meer invloed uit te oefenen op: planning van de verpleging, uitvoering van de verpleging en het dragen van verantwoordelijkheid voor verpleegkundige handelingen. Het gemak waarmede deze doelen kunnen worden bereikt hangt af van de leiderskwaliteiten van het afdelingshoofd. De hoofdverpleegkundige dient een harmonie na te streven en een balans te wormen tussen de verpleegkundige discipline, andere gezondheidszorgprofessies en het brede publiek. Vandaag iser méêr da nooit in de geschiedenis van de verpleging een behoefte aan sterke, morele leiders. Moreel leiderschap kan men omschrijven als een passieve vorm van actie, waa rbij de leider het werk van de groep gemakkelijk maakt teneinde een speciaal doel - door de groep omschreven - te bereiken. De toegenomen vraag naar goed leiderschap is ontstaan uit de toeneming van de arbeidsverdeling. Een morele leider dient de gaven te hebben van: hypothetiseren, stimuleren en gidsen, analyseren van verhoudingen, besluitvaardigheid en vertrouwvolle actiegerich theid."*

Zij haalt een voorbeeld aan van twaalf top-managers van grote ondernemingen in de Verenigde Staten. Zij stelden een lijst op van kenmerken welke zij essentieel achtten voor effectiefleiderschap. Dat wa ren: een vragende instelling, de mogelijk heid om op grond van aanwezige feiten onafhankelijke beslissingen te nemen, een ondermemende houding t.o.v. het oplossen van problemen en een capaciteit om alternatieven te overwegen.

De leider dient ook doelstellingen van samenwerkende groepen op elkaar af te kunnen stemmen. Niet alleen de vaktechnische, maar ook het beleid en de visies van de verschillende disciplines.

Cornelius (1976) die leiderschapskwaliteiten van verpleegkundigen bespreekt zegt ook dat het stimuleren van goede werkmotivaties een taak van het afdelingshoofd is. Hij zegt: "De verpleegkundige professie word t genoemd het geweten van het gezondheidszorg-systeem." Hij werkt de consequenties daarvan uit.

In bovengenoemde visies op leiderschap van het afdelingshoofd komt naar voren dat het afdelingshoofd naast het leiding geven aan verpleegkundigen ook een balans moet vinden tussen het werk van de verpleegkundigen en andere gezondheidszorgwerkers. Bovendien moet het psychologische klimaat waarop de afdelingswerkzaamheden zich baseren, door haar worden begeleid en positief gestimuleerd. Deze drie facetten - leiding over verpleegkundigen, harmonie met andere groepen en integratie - zullen via het literatuuronderzoek worden besproken.

\section{Leiding over verpleegkundigen}

Het beeld van de over-kordate hoofdzuster is een verschijnsel dat door nieuwe inzichten in effectief leiderschap en betere opleiding, gaat verdwijnen. De ouderen onder ons herkennen nog dat Kenau-fenomeen, waarover Gerversman in 1963 het volgende schreef:

"De hoofdverpleegkundige, opgaand in haar werk op de afdeling, gaat zich zo vereenzelvigen met de afdeling, dat zij de heerseres gaat worden over een rijk waarvan 
zij de grenzen met de grootste nauwlettendheid bewaakt, bezoek van andere afdelingen, of dit nu een zuster of patiënt is, met wantrouwen beziet, het specialisme dat op haar afdeling wordt uitgevoerd als het enige ware beschouwt, waarbij alleen op haar afdeling wordt gewerkt, terwijl er op andere afdelingen slechts geknoeid wordt, zoals men dit vaak in onderontwikkelde gebieden kan verwachten."

De stijl van leidinggeven is aan het veranderen. Maar dat betekent nog niet dat conflicten tussen hoofdverpleegkundigen en hun staf verdwijnen. In de literatuur vinden wij aa nwijzingen dat daar juist de meeste spanningsbronnen liggen, méér dan in conflicten tussen artsen en verpleegkundigen. Marshall (1980) schrijft:

"Al mijn vakkundige informanten zeiden dat de werkrelaties tussen verpleegkundigen en superieuren beschouwd dienen te worden als potentiële stressoren. Als de meest kwetsbare relatie wezen zij naar die van de hoofdverpleegkundige en haar staf. Zij bepaalt voornamelijk hoe de afdelingswerkzalambeden verlopen en het klimaat waaronder dit gebeurt."

Zij gaat niet in op de oorzaken daarvan. Onze vakkundige informanten zeggen dat deze conflicten vaak ontstaan omdat de verpleegkundigen geen oog hebben voor de moeilijke positie van het afdelingshoofd. Het schipperen tussen allerlei verwachtingen en eisen, gebrek aan personeel, onduidelijke afspraken en belangentegenstellingen maken de leider kwetsbaar. Volgens Cassee (1967) plaatsen de toenemende ingewikkeldheid van de ziekenhuisorganisatie en de andere eisen die het personeel aan de leiding stelt, de hoofdverpleegkundige in een moeilijke leiderspositie. Stolte (1976) werkt dit verder uit:

"De stijl van leidinggeven is geleidelijk meer die van de human-relationsapproach. Bij dit alles blijft een belangrijk uitgangspunt dat een en ander niet mag leiden tot een groter risico voor de patiënten. Het is dit aspect, dat het leiding geven aan de verpleegkundige arbeid zo moeilijk maakt, omdat een conflict tussen deze eis en de voorgaande lang niet is uitgesloten."

Cassee (1976) wijst erop dat ook het algemene leiderschapsklimaat in ziekenhuizen invloed uitoefent op de leiderschapsstijl van hoofdverpleegkundigen. Als de directie van het ziekenhuis sterk autoritair en instrumenteel gerichte leiding geeft, kan men verwachten dat de hoofdverpleegkundige deze vorm van leidinggeven overneemt.

\section{Harmonie met groepen}

De hoofdverpleegkundige geeft behalve leiding aan beroepsgenoten (verpleegkundigen) ook een zekere sturing aan andere disciplines die op de afdeling werken. Specialisten, paramedische werkers en diensten, welzijnswerkers, civiele, administratieve, economische en personeelsdiensten, opleidingen, inkoopafdelingen, vragen op de ziekenafdeling tijd en aandacht van de hoofdverpleegkundige. Ze hebben ieder een eigen vaktechnische of wetenschappelijke achtergrond. De zelfstandigheid, waartoe vellen zijn opgeleid, (in vrijwel geen enkele opleiding wordt op de waarde van andere disciplines gewezen) bemoeilijkt een goed functioneren in teamverband. Mintzberg (1979) wijst erop dat de structuur van het ziekenhuis het 
bouwen van privé-koninkrijkjes binnen de organisatie schijnt te bevorderen. Volgens hem kom dit namelijk special voor in organisaties met functiegerichte structuren, zoals het ziekenlhuis. Niemand kan beoordelen of een bepaalde dienst terecht werk weigert en redenen heeft om meer personeel te vragen of apparaten aan te schaffen. Planning „kostenbewaking en beoordeling over efficiency zijn moeilijke vraagstukken in functiegerichte bedrijven. Het is voor de hoofdverpleegkundige moeilijk om goed in te schatten waar zij wél en niet kan en moet volhouden, als anderen zeggen niet aán haar vraag om dienstverlening te kunnen voldoen.

\section{Integratie}

Naast het geven van leiding aan de verpleegkundigen houdt het leiderschap van hoofdverpleegkundigen ook, zoals we hiervoor zagen, in: het trachten te sturen van de werkzaamheden van andere ziekenhuismedewerkers, voor zover dat op en ten behoeve van de ziekenafdeling geschiedt. Bij dat laatste komt, als uitvloeisel van de grote zelfstandigheid van iedere discipline, nog een probleem om de hoek kijken, dat nu besproken zal worden. De hoofdverpleegkundige heeft nl. ook tot taak de doelstellingen van groepen op elkaar af te stemmen.

Verpleegkundige doelstellingen zal het afdelingshoofd met haar staf samen bespreken en nastreven. Vaktechnische doelstellingen van andere beroepsgroepen zal de hoofdverpleegkundige als feiten accepteren. Maar als de middelen, waarmede de verschillende disciplines hun doel willen bereiken, tegenstrijdig zijn, is bijsturen noodzakelijk. Als de chirurg aan de patient frequente loopoefeningen voorschrijft, maar de behandelende internist complete bedrust noodzakelijk acht, dan staan verpleegkundigen voor een dilemma. Tegenstrijdige opdrachten komen nogal eens voor. Bij uitsplitsende specialisaties nemen deze problemen toe. De op specialisme gebaseerde macht, waar Vollebergh (1976) over spreekt, werkt deze verwarring extra in de hand. De hoofdverpleegkundige mist echter de bevoegdheden om knopen door te hakken.

Verweij ( 1981 ) signaleert deze problemen ook:

"Een logisch gevolg van de bevoegdhedenstructuur zou zijn (trouwens van de gehele medische ontwikkelling) dat een medicus formeel operationele leiding zou geven betreffende de uitvoering en coördinatie van de patiëntenzorg. Indien deze leidinggevende en coördinerende taak wordt gedelegeerd aan de verpleging, zoals nu het geval is, dan zal deze vanuit de verpleegafdeling bezien horizontale relatie in de formele structuur tot uiting moeten komen. Conclusie op grond van bovenstaande analyse is: de bijzondere informele bevoegdheid van de medische specialisten en de delegaties ervan aan de verpleging binnen een matrix-organisatie te formaliseren."

Geeft de integratie van vaktechnische handelingen al problemen, nóg moeilijker is een eenheid te krijgen in beleid en visie op elementaire zaken zoals patiëntenbegeleiding, het inlichten over zijn ziekte door wie, wat, waar, wanneer en hoe, de manier waarop het werk gedaan moet worden, wat men eigenlijk van wie verwacht en hoe men zich opstelt tegenover problemen met patiënten, familie en personeel. 
Deze problemen raken een veel fundamenteler dimensie van de werker", nl helterrein van waarden en normen waarop men zich baseert.

Cherps (1980) stelt dat in een zeer gestratificeerde gemeenschap wasurden en cultuur van de top naar beneden sijpelen. Dit stand punt is vanuit de sociologic bestreden. De dominante ideologie wordt in veel maatschappijen niet door ondergeschikten gedeeld. Zo is het vaak ook op de ziekenafdeling. De waarden en normen van verpleegkundigen over de juiste patiëntenbegeleiding wijken af van die van de andere werkers in het ziekenhuis. De hieruit voort wloeiende verschillen in benadering van de patiënt leiden op den duur tot grote conflicten op de ziekenafdeling.

\section{Personeelsbezetting}

In de organisatiekunde legt men sterk de nadruk op het werband tussen leiderschapsgedrag en arbeidsk limaat. Soms krijg je de indruk dat een goede leider de gehele afdelingsproblematiek zou kunnen oplossen. Verpleegkundig directeur Van Enk (1979) heeft daar bedenkingen tegen:

"Er wordt nog steeds gedaan alsol de patiënten en leerlingen uitsluitend aan wat begeleiding mankeert, terwijl er fouten gemaakt worden door gebrek aan tijd en toezicht. Waarom erkennen wij als directeuren niet in het publiek wat onze hoofdverpleegkundigen ons dagelijks vertellen?"

Volgens haar zijn de problemen terug te voeren op gebrek aan personeel.

Gebrek aan personeel moet zeker genoemd worden als belangrijke oorzaak van conflicten op de ziekenafdeling, tussen werpleegkundigen onderling en vooral tussen hen en hoofdverpleegkundigen. Door gebrek aan tijd en hulp staat het afdelingshoofd onder spanning. Dat geeft aanleiding tot jachtige bevelen en haastige, onduidelijke opdrachten.

Het eerder gemelde verloop onder verpleegk undigen, heeft uiteraard invloed op de personeelsbezetting. Maar daarnaast ontwikkelden zich normen ten aanzien van de personeelsbezetting in de ziekenhuizen de zg. COTG-normen (Centraal Orgaan Tarieven Gezondheidszorg), op grond waarvan het aantal toegestane arbeidsplaatsen voor verpleegkundigen $\mathrm{krap}$ is en in veel gevallen niet toereikend.

Karsemeyer (1973) spreekt over een overspannen werksituatie door het tekort aan verpleegkundig personeel, waardoor er gevaar dreigt voor de volksgezondheid.

De overheid kondigde (overigens zonder overleg met verpleegkundigenorganisaties) op 22 november 1973 bezuinigingsmaatregelen voor ziekenhuizen aan. Onder meer werd een personeelsstop ingevoerd. Door deze maatregelen, tegelijk ingevoerd met een kortere werkweek, meer wakantie, een hogerbedbezettingspercentage en een snellere patiëntendoorstroming, draaiden de ziekenafdelingen dol. Het ziekenhuis ging lijken op een bedrijf, waarin de lopende band wat sneller werd gezet. 
De Structuumota van de Volksgezondheid (1974) stimuleerde een nóg intensiever bedgebruik.

Een creatieve opstelling van het afdelingshoofd wordi door gebrek aan personeel in de kiem gesmoord. Een aldelingshoofd vertelde bovendien:

" $k$ wil grag vemieuwingen op de afdeling invoeren, maar dan denkt de directie onmiddellijk dat ik personeel over heb en komt dan een paar krachten bij me weghalen."

McFarlane (1977) zegt dat de overbezette hoofdverpleegkundigen zelfs niet op creatieve ideeën komen, maar een soort crisisbeleid voeren van waaruit geplande patiëntenzorg niet goed mogelijk is. Gray-Toft en Anderson (1981) komen na een onderzoek onder 122 verpleegkundigen op vijf patiëntenafdelingen tot de uitspraak dat werkoverbelasting de grootste stress van verpleegkundigen is.

Deze en andere uitspraken in de literatuur bevestigen de indruk dat in het buitenland de situatie niet beter is. Ook daar wijzen onderzoekers op de fnuikende werking van personeelsgebrek. French and Caplan (1973) toonden in een onderzoek aan dat werkoverbelasting een negatieve invloed heeft op het zelfbeeld. De lage zelfachting onder verpleegkundigen is misschien mede te wijten aan personeelstekorten.

\section{Intermenselijke verhoudingen}

De literatuur noemt als bron van slechte intermenselijke verhoudingen op de ziekenafdeling - naast personeelstekort - starre hiërarchische structuren, gebrek aan ondersteuning, disfunctionele autonomie van professionals, belangentegenstellingen, tegenstrijdige of onduidelijke verwachtingen, gebrek aan inspraak en zeggenschap over eigen verpleegkundig handelen, motivatiecrises, slecht begrepen of uitgeoefend leiderschap van de hoofdverpleegkundige, niet realistische opleidingen, gebrekkige inzichten over samenwerkingsverwachtingen en nog vele andere. De belangrijkste komen nu aan de orde: de relatie tussen artsen en verpleegkundigen, de erkenning van het verpleegkundigenberoep en de promotiemogelijkheden. Intermenselijke verhoudingen tussen verplleegkundigen onderling worden in de volgende paragraaf besproken.

\section{Relatie arts-verpleegkundige}

Bij de aparte bespreking van de verhouding tussen specialisten en hoofdverpleegkundigen (paragraaf 2.3 ) is al naar voren gekomen dat de problemen tussen arts en verpleegkundige vooral liggen op het gebied van de onderlinge samenwerking en taakafbakening. Dat uit zich op de ziekenafdeling.

De problematische samenwerking wijt Katz (1963) aan het feit dat artsen afhankelijke, serviele verpleegkundigen eisen en verpleegkundigen zelfstandigheid en respectvolle behandeling verlangen. Hoekelman (1975) wijst ook op de afwezigheid van respect van artsen voor verpleegkundigen. Hij noemt een aantal factoren die optimale samenwerking be lemmeren, o.a.: een fundamentele onoprechtheid tussen artsen en verpleegkundigen, de man-wrouw relatie, verschil in 
opleidingsniveau, verschil in financiële beloning, verschil in sociale status en afkomst, en als belangrijkste oorzaak een groot gebrek aan wederzijds begrip voor elkaars werk, waarover zo dadelijk iets meer.

Onenigheid tussen artsen en verpleegkundigen over de afbakening van elkaars rol heeft gevolgen voor het moreel van verplegenden. Cassee (1967) toonde in een onderzoek aan dat naarmate het verschil in deze opvatting tussen hooldverpleegkundigen en artsen groter is, het verloop onder verpleegkundig personeel toeneemt. In de slotopmerkingen zegt hij:

"In het ziekenhuis is het optreden van hoofdverpleegster en artsen duidelijk van invloed op het ziekteverzuim van verplegenden."

Sociaal-kritische auteurs wijzen op het steeds technischer worden van de taak vande arts, waardoor zijn rol als vert rouwensman van de patiënt wordt aangetast. Hierdoor komt ook de relatie met verpleegkundigen, die zich opstellen als advocaat van de zieke, onder spanning.

Niet alleen de overbelasting van verpleegkundigen, ook de vermoeidheid van artsen en met name van arts-assistenten, speelt een rol bij de stroeve samenwerking in de dagelijkse praktijk. De Gruyter (1982) maakt melding van de excessief lange werktijden van specialisten in opleiding. Zij maken gemiddeld werkweken van zeventig uren gedurende een opleidingstijd van twee tot zes jaar.

\section{Erkenning verpleegkundigen}

De geringe erkenning en achting voor het verpleegk undig beroep, speciaal voor het "handwerk" verplegen, is ook een oorzaak van spanningen op de afdeling. De internist Geiger (1976) vertelt over zijn persoonlijke ervaring tijdens zijn ernstige ziekte en opname op zijn eigen afdeling. Hij kreeg een kamertje tegenover de dienstkeuken en hoorde gesprekken tussen verpleeghulpen:

"Ik had de kans hen gade te slaan en te beluisteren. Zo werd het mij duidelijk dat hun gezichtspunten over het leven op zaal en de patiënten totaal verschillen van de gezichtspunten van de artsen en verpleegkundigen. De hulpen werden buiten elk curatief werk gesloten en ze kregen het "afval-werk" zoals hulp bij defaecatie, braken, urineren, eten en voldoen aan de emotionele en persoonlijke noden van de patiënt. Maar deze belangrijke functies werden totaal niet door het overige personeel gewaardeerd. Het had geen enkele status. Toen ik als internist terugkwam op zaal heb ik hen altijd met andere ogen moeten bekijken dan voor mijn ziekte."

Het gebrek aan achting voor het beroep blijkt ook uit het feit dat werpleegkundigen uit de leiding worden geweerd. Niet alleen vanuit de verpleegkundige, maar ook vanuit de medische hoek wordt hiertegen geprotesteerd.

Selow en Clay (1979) schrijven:

"In het belang van een verantwoorde patiëntenzorg zal de verpleegkundige 
moeten streven naar een volwaardige werpleegkundige inbreng in het ziekenhuisbeleid, omdat op het ogenblik de belangen van de medische specialisten - de vrije beroepsbeofenaars binnen het ziekenhuis - teveel domineren.

Daardoor gaan de economische overwegingen overheersen en wordt de kwaliteit van de verpleging bedreigd tot schade van die patiënten welke medisch-technisch niet of nauwelijks kunnen worden geholpen."

Verpleegkundigen willen zelf verantwoordelijkheden dragen en hun eigen terrein niei ondergeschikt maken aan de arts. Tussen het ideaalbeeld dat verpleegkundigen wan hun werk hebben en de rea liteit is echter een groot verschil. Het is opvallend hoeveel verpleegkundigen na enkele jaren praktijk het beroep verlaten, omdat zij in hun dagelijks werk op de afdeling dat ideaal niet kunnen verwezenlijken, en dus niet alleen de erkenning van hun beroep ontberen, maa rook het respect voor zichzelf verliezen. Pay (1975) zegt dat eigen ervaringen (verpleegkundige) en literatuurbevindingen haar vermoeden bevestigen dat verpleegkundigen hun baan verlaten door het werliezen van zelfachting. Haar informanten vertelden dat zij in andere banen meer respect ondervonden dan in de ziekenhuisomgeving.

\section{Promotiemogelijkheden}

Als derde factor van slechte verhoudingen op de afdeling noemden wij gebrek aan promotiemogelijkheden. Een aantal factoren kan daarvoor verantwoordelijk zijn, zoals het eerder omschreven gebrek aan achting voor de verpleging, de overwegend vrouwelijke verplegingsbevolking en het gebrek aan emancipatie van de vrouw, de maatschappelijk verankerde overwaardering van intellectuele arbeid en onderwaardering van handenarbeid, het gebrek aan leiders met visie en, niet in het minst, het ontbreken van verpleegkundige research.

Door gebrek aan verpleegkundig onderzoek stagneert in Nederland verpleegkundige theorievorming. Het verplegingsvak staat daarom op dood spoor. Van eigen vakgenoten komen geen nieuwe impulsen en inzichten over het beroep. Het beroep kan zich niet ontplooien.

Fottler et al (1980) zeggen daarover:

"De meeste verpleegkundige posities zijn doodlopend, d.w.z. zij hebben geen klinische route voor een opwaartse mobiliteit. Deze geblokkeerde mobiliteit heeft aanleiding gegeven tot werk-ontevredenheid, hoge verloopcijfers en een gebrek aan stimulansen om zich in de verpleging te begeven of er te blijven."

In het artikel spreken zij over de lage status en de slechte salariëring en arbeidsvoorwarden van verpleegkundigen.

In Nederlandse ziekenhuizen kunnen verpleegkundigen alleen promotie maken via een lijnfunctie, dus naar posities als afdelingshoofd, coördinerend hoofdverpleegkundige, hoofd verplegingsdienst of verpleegkundig directeur; alle functies zonder direct contact met de verpleging en de patiënt. Staf-functies voor verplegenden, zoals men die in de Angelsaksische landen kent, zoals verpleegkundig specialist, bestaan in Nederlandse ziekenhuizen niet. Promotie betekent in Nederland dus dat waardevolle verpleegkundige praktijkkennis verloren gaat. 
Sommigen denken dat het toenemend aantal buitenshuis werkende vrouwen de verpleging ten goede zal komen. Maar ook zij zullen carrière-aspiraties hebben, zie bv. Baumgart (1981):

"Meer vrouwen willen een groot deel van hun tijd besteden aan beroepsactiviteiten. Slechte arbeidsomstandigheden werden vroeger door verpleegkundigen geaccepteerd omdat zij hun functie niet als een blijvend levenswerk zagen. Verpleegkundigen met carrière-aspiraties winden in ziekenhuizen geen aangepaste werkcondities."

Gebrek aan groepsgewoel en groepsoptreden is ook verantwoordelijk voor de geringe promotickansen van verpleegkundigen.

De staat heeft weel invloed op de gezondheidszorg. In adviserende commissies komt men zelden verpleegkundigen tegen.

De externe vereisten ontbreken om het vastgelopen raderwerk van de verpleging op gang te brengen. Anderzijds is het goed mogelijk dat hulp van buitenal nog meer frustraties brengt als de interne ziekenhuisstructuren zich niet aanpassen. Verweij (1981) die ziekenhuisstructuren aansprakelijk stelt voor de problemen binnen de verpleging, schrijft:

"Hier stuiten we op de vraag, of hoger opgeleide en in de nabije toekomst universitair opgeleide verpleegkundigen op duurzame wijze kunnen worden ingezet bij de directe patiëntenzorg op de verpleegafdeling, zonder dat dit bij alle categorieèn werplegenden tot (nog meer) frustraties leidt."

\section{Samenvatting}

De moderne ziekenhuisafdeling verschilt veel van de patiëntenverblijven uit de Middeleeuwen. Niet alleen in bouwkundig opzicht; ook sleer, medische en verpleegkundige zaken veranderden drastisch.

Verpleegkundigen, artsen en andere gezondheidszorgwerkers stellen aan de leiding van de ziekenafdeling hoge eisen. Leiding geven op de verpleegafdeling is moeilijk, omdat de middelen en wijze waarop vertegen woordigers van verschillende disciplines doelen willen realiseren, soms verschillen. De hoofdwerpleegk undige moet proberen een oplossing te vinden, maar mist de bevoegdheid om knopen door te la aken. De visies, waarden en normen van verpleegkundigen blijken somsaf te wijken van dic van de andere werkers in het ziekenhuis.

De functiegerichte ziekenhuisstructuur bevordert het bouwen van privé-koninkrijkjes binnen de organisatie. De hoofdverpleegkundige kan soms moeilijk beoordelen of een bepaalde dienst terecht hulp weigert. De huidige ziekenhuisstructuur maakt efficiënt leiderschap onmogelijk.

De personeelsbezet ting op de ziekenafdeling is een bron van voortdurende zorg van het afdelingshoofd. Door personeelsbeperkingen, tegelijk met de invoering van een kortere werkweek, meer vakantic, hogere bedbezettingspercentage en snellere patiëntendoorstroming, draaiden ziekenafdelingen dol. Het ziekenhuis ging lijken op een bedrijf waarin de lopende band sneller werd gezet. Dit heeft onmiddellijke 
gevolgen voor de intermenselijke verhoudingen op de afdeling. De hoofdverpleegkundigen moeten schipperen tussen (redelijke) verwachtingen van het afdelingspersoneel omtrent vrije dagen, werkomstandigheden, werkverdeling, begeleiding, en soepelle controle enerzijds, en overmatige werkhoeveelheid anderzijds. Werkoverbelasting heeft een negatieve invloed op de zelfachting van de werker. Dat kan een van de redenen zijn van het lage zelfbeeld van verpleegkundigen.

De relaties, niet alleen tussen verpleegkundigen onderling, maar ook tussen artsen en verpleegkundigen, worden aangetast. Niet in het minst doordat men onderling geen begrip kan opbrengen woor wederzijdse problemen.

Andere oorzaken voor de slechte intermenselijke verhoudingen op de ziekenafdeling zijn: gebrek aan erkemning van de waardevolle bijdrage van de verpleging, gebrekkige autonomie van verpleegkundigen en geringe promotiemogelijkheden.

\subsection{De hoofdverpleegkundigen en hun staf}

Deze paragraaf gaat over de hoofdpersoon van dit boek, de hoofdverpleegkundige. De literatuur geeft maar weinig informatie over de persoon van het afdelingshoofd. Het onderzoek zal zich daarom o.m. moeten richten op de vraag: "Hoe ziet de hoofdverpleegkundige zichzelf en hoe zien de medewerkers haar?"

Over de taak van de hoofdverpleegkundigen spreken auteurs, veldonderzoekers en hoofdverpleegkundigen in termen van rolonduidelijktheid, tegengestelde verwachtingen en verschillende inzichten. Toch blijken in de meeste ziekenhuizen functiebeschrijvingen te zijn die concreet en met duidelijk omschreven begrippen, onderverdeeld in punten, voorzien van toelichtingen, de taak van hoofdverpleegkundigen omschrijven.

Er is dus een duidelijk verschil tussen de theorie van de functiebeschrijving en de praktijk op de ziekenafdeling.

Bij het belichten van de hoofdverpleegkundige vanuit de derde invalshoek, via de intermenselijke verhoudingen tussen hoofdverpleegkundigen en verpleegkundigen blijkt dat de Nederlandse literatuur ook karig is met informatie over dit onderwerp.

Wij zullen de literatuurbevindingen als volgt gerangschikt weergeven:

- kenmerken wan (hoofd)verpleegkundigen;

- hoofdwerpleegkundigen en verpleegkundigen op de afdeling;

- de taak-en rolopvatting van hoofdverpleegkundigen.

\section{Kenmerken van (hoofd)verpleegkundigen}

Weinig onderzoekers hebben de persoonlijkheidskenmerken van hoofdverpleegkundigen tot onderwerp van studie gemaakt. Over de persoon van verpleegkundigen in het algemeen bestaal wel wat literatuur.

Een onderzoek van Pool (1978) bijvoorbeeld geeft enige informatie. Hij bestudeerde o.m. de motivatie onder artsen en (hoofd)verpleegkundigen. De roepings-en dienst- 
verleningsopvatting blijkt bij verpleegkundigen sterker aanwezig dan bij artsen. Hoofdverpleegkundigen blijken de "Tender-Loving-Care-ideologie" minder te zijn toegedaan dan gediplomeerden en leerlingen. Ook in Amerika is dat zo (Kramer (1974). Katz (1969) citeert een hoofdverpleegkundige:

"TLC (Tender Loving Care) is important, but you can go too far with it, and before you know it you have your hands full of chronic complainers."

Deze houding is ook in Nederlandse ziekenhuizen bekend, maar houdt waarschijnlijk meer verband met personeelstekorten dan met kenmerken van (hoofd)verpleegkundigen.

Katz (1969) spreekt over een onderzoek dat Habenstein en Christ (1955) verrichtten onder verpleegkundigen. Zij onderscheiden drie categorieën:

- de professionalist, die zich primair richt op kenniswerwerving en -toepassing. De patiënt komt op de tweede plaats. Een goede en wetenschappelijke aanpak van de problemen heeft de voornaamste belangstelling. Zij is voorstander van vernieuwingen;

- de traditionalist, die vooral de toewijding centraal stelt. Zij bewaakt de tradities van het ziekenhuis en de specialisten. Zij heeft weinig kritiek op bestannde situaties, zij is geen voorstander van vernieuwingen;

- de practicus, die zich niet speciaal bezighoudt met wetenschap of uitbreiding van kennis, noch met ziekenhuistradities. Zij wil beoordeeld worden in termen van efficiënt werken en ijver. Zij is het proto-type van de vlijtige aanpakker.

Katz zegt dat deze drie typen voor verschillende ziekenhuisdiensten kiezen; bv. opleiding, middenkaderfunctie en/of directe patiëntenzorg.

Cassee en Philipsen (1968) zochten onder verpleegkundigen naar relaties tussen autoritaire persoonlijkheidskenmerken en opvattingen over leiderschapsgedrag van hoofdverpleegkundigen. Een algemene conclusie was dat verpleegkundigen met een autoritaire instelling vooral tevreden waren met een hoofdverpleegkundige die "rust" en "orde" stelt boven integratie van menselijke verhoudingen. De auteurs zeggen:

"Belangrijkste bevinding blijft het feit, dat integratief leiderschapen werkoverleg de hoge F-scoorder (autoritaire persoonlijkheid) emotioneel weinig beroeren. Belangrijk, niet omdat het een hypothese bevestigt, maar omdat het voor de vormgeving van de werkverhoudingen in de maatschappij belangrijke consequenties heeft. Zowel op sociaal wetenschappelijk als op ideologische en levensbeschouwelijke gronden werd en wordt sterk aangedrongen op bevordering van integratief leiderschap en werkoverleg, welke men kan beschouwen als de micro-sociale variant van medezeggenschap. Hoewel er ook na deze bevindingen geen reden is om deze twee micro-sociale inspraakmechanismen de rug toe te keren, maken deze resultaten toch "sadder and wiser'."

Biografische kenmerken wan (hoofd)verpleegkundigen zijn met wisselend resultaat in verband gebracht met verlooppercentages. Deze studies bevatten o.m. variabelen als leeftijd, burgerlijke staat, hoeveel ja ren gehuwd, aantal kinderen, erwaring, aantal 
dienstbetrekkingen, duur wan de betrekking en opleidingsniweau. De onderzoekers zeggen dat maar weinig factoren een consistente relatie vertonen met werloop.

\section{Hoofdverpleegkundigen en verpleegkundigen op de afdeling}

In de zorg voor de patiënten op de afdeling, kande hoofdverpleegkundige steunen op een aantal verpleegkundigen, zowel gediplomeerd als leerling. Zij zijn de functionarissen die het beste haar verpleegkundig werk kunnen beoordelen. Bij het dagelijks werk is de hoofdverpleegkundige het meest van gediplomeerden en leerlingen afhankelijk. Wij mogen veronderstellen dat beide groepen prijs stellen op een goede relatie.

Wat zegt de literatuur daarover?

Shaw en Heyman (1980) die een onderzoek deden onder 171 verpleegkundigen in vier Engelse ziekenhuizen, kwamen tot de volgende conclusie:

"Ons onderzoek geeft aanwijzingen in de richting dat gezagsbotsingen tussen de verpleegkundigen op een afdeling méér voorkomen dan conflicten tussen verpleegkundigen en de medische staf."

Leatt and Schneck (1980) vroegen aan 153 hoofdverpleegk undigen een aantal voorvallen te noemen die zijals bijzonder spanningsvol ervoeren. Als eerste drie noemden zij:

- onbereikbaarheid van de specialisten;

- werkoverbelasting;

- conflicten tussen verpleegkundigen.

Op de vraag of die voorvallen vaak voorkomen, antwoordden zij:

- onbereikbaarheid specialisten

soms vaak

- werkoverbelasting

$58,8 \%$ $15,0 \%$

- conflicten tussen verpleegkundigen

$43,4 \%$ $20,4 \%$

$60,8 \%$ $3,3 \%$

Everly en Falcione (1976) onderzochten welke factoren bijdragen tot arbeidstevredenheid van verpleegkundigen. Als belangrijkste voorwaarde voor arbeidssatisfactic vonden zij: goede verhoudingen tussen collega's en tussen verpleegkundigen en hoofdverpleegkundigen.

Andere studies tonen verband tussen arbeidsontevredenheid en verloop.

Daardoor wordt de volgende keten duidelijk:

Conflicten verpleegkundigen - Arbeidsontevredenheid - Verloop.

Om deze reden is het belangrijk in de literatuur te zoeken naar oorzaken van conflicten tussen verpleegkundigen en afdelingshoofd. Vele zijn te herleiden tot reeds besproken spanningen, zoals personeelstekorten en gebrekkige leiderschapskwaliteiten van het afdelingshoofd. Deze worden hier niet meer opnieuw aangehaald.

Conflicten tussen hoofdverpleegkundigen en leerlingen blijken soms een andere bron te hebben dan die tussen hoofdverpleegkundigen en verpleegkundigen. Daarom zullen spanningen tussen hoofdverpleegkundigen en gediplomeerden en tussen hoofdverplecgkundigen en leerlingen apart worden besproken. 


\section{Spanningen tussen hoofdverpleegkundigen en verpleegkumdigen}

Hierin kunnen we onderscheiden:

- spanningen door slechte werkcondities;

- spanningen door gebrek aan duidelijke doelstellingen of door gebrek aan stimulansen;

- spanningen door gebrek aan collegialiteit;

- spanningen door wederzijdse verwachtingen.

\section{Spanningen door slechte werkeondities}

Berting en De Sitter (1971) wijzen op de relatie tussen kwaliteit van de arbeid (boeiend werk, zelfstandig werk, medeverantwoordelijkheid, status en erkenning, identificatie met de omgeving en mogelijkheden tot ontplooiing en promotie), arbeidstevredenheid en participatie. Slechte arbeidscondities bevorderen vervreemding en verloop. De directe kenmerken van vervreemd ged rag zijn volgens hen: af wijzing, wantrouwen en een geringe bereidheid tot het brengen van offers. De slechte werkcondities in het ziekenhuis en de daardoor ontstane vervreemding onder verpleegkundigen vormen een directe bedreiging van de goede relatie tussen hooldverpleegkundigen en hun verpleegkundige medewerkers, immers de hooldverpleegkundige moet de verpleegkundigen permanent vragen offers te brengen.

\section{Spanningen door gebrek aan duidelijke doelstellingen of door gebrek aan stimulansen}

Vooral in de Amerikaanse literatuur wordt gewezen op de relatie tussen gebrek aan duidelijke doelstellingen en een laag moreel onder verpleegkundigen. Het begrip "moreel" verwijst naar de mate waarin individuen als leden van een groep samenwerken ter bereiking van een groepsdoel of -doelen. Een hoog moreel betekent: grote mate van groepsbinding, gering verloop, weing̈g verzuim, intensief met elkaar sa menwerken waarbij men niet het minst aantrekkelijke werk voor een ander laat liggen. Een laag moreel is daarvan het tegendeel: "zich drukken"lijkt de beste omschrijving. Een laag moreel van het personeel geeft uiteraard veel problemen voor het afdelingshoofd.

Wat moet in de verpleging verstaan worden onder duidelijke doelstellingen?

Coser (197]) geeft hierin inzicht. Zij deed onderzoek in een verpleeghuis voor ongeneeslijk zieken én in een revalidatiecentrum. De leiding van het verpleeghuis slatgde er niet in voor het verpleegkundig personeel duideljjke, zinvolle doelen te stellen. Het verzorgen van chronisch zieken heeft in de prestatiemaatschappij, aldus Coser, ook weinig status.

Ondat ze geen doel in hun verplegende taak zagen, en daaraan ook weinigstatus konden ontlenen, gingen de verpleegkundigen zich richten opeen medisch doel: het beter maken van de patiënt. In een inrichting voor chronisch zieken is dit niet haalbaar. Daarom verdween in dat verpleeghuis de motivatie.

In ziekenhuizen wat medici sterk domineren en de verpleging als een ondengeschikte factor beschouwen zien we een overheersing van het putr medische doel, het ver- 
dwijnen van duidelijke verpleegkundige doelstellingen, en een daling van het moreel van het verpleegkundig personeel.

Gebrek aan stimulansen kan apathie bevorderen, en daardoor verzuim en verloop. Veel en veelsoortige taken en functies (een complexe rollen-set) stimuleren daarentegen de werker en zijn orngeving.

Dit zag Coser in het revalidatiecentrum:

"In het revalidatiecentrum hadden verpleegkundigen méér taken en méér contacten dan de verpleegkundigen in het verpleeghuis. De revalidatie-verpleegkundigen bleken beter en juister gemotiveerd te zijn.

Dit onderzoek doet vermoeden dat complexe role-sets vervreemding voorkomen. Het sociaal mechanisme - dat ontstaat om tegenstrijdigheden in rolverwachtingen op te heffen - zorgt ervoor dat steeds opnieuw rollen worden opgebouwd, bijgeschaafd en afgebroken. Dit proces schijnt gelijk te zijn aan wat Mead noemde de "game" in tegenstelling tot de "play". In een game is een aantal individuen tezamen betrokken. Zij moeten de rol van iedereen "pakken". Dit is niet het geval bij de "play" zoals het kind doet. Hij speelt slechts zijn eigen rol en let niet op die van anderen. In het revalidatiecentrum kan men de situatie van de "game" observeren. In een beperkte rollen-set heeft de actor de neiging tot de "play" zoals in het verpleeghuis."

Met deze uitleg is meer te begrijpen van de achtergronden van de cijfers over het personeelsverloop in Nederlandse gezondheidszorginstellingen. De gegevens zijn afkomstig van het Nationaal Ziekenhuisinstituut te Utrecht (1980).

Tabel 3. Gemiddelde verlooppercentages per sector over de jaren 1976, 1978, 1979 en 1980.

1976 $\quad 1978 \quad 1979 \quad 1980$

Algernene ziekenhuizen

Academusche ziekenhuizen

Categorale ziekenhuizen

Revalidatiecentra

Psychiat rische ziekentuizen

Zwak zinunigenimichtingen

Verpleeghuizen

$\begin{array}{llll}22 \% & 20 \% & 20 \% & 21 \% \\ & & & 20 \% \\ & 24 \% & 18 \% & 20 \% \\ 19 \% & 19 \% & 21 \% & 20 \% \\ 16 \% & 20 \% & 20 \% & 22 \% \\ 27 \% & 28 \% & 27 \% & 26 \%\end{array}$

Wij zien dat in de verpleeghuizen de gemiddelde verlooppercentages hoger liggen dan in de ziekenhuizen.

\section{Spamningen door gebrek aan collegialiteit}

In het voorafgaande is reeds gesproken over de mogelijkheid van een laag moreel onder verpleegkundigen. Dat kan tot gevolg hebben dat collegialiteit verdwijnt. Men heeft niet veel voor elkaar over, laat de vervelende karweitjes voor een ander liggen en "drukt" zich waar mogelijk.

Ook komt oncollegiaal gedrag voor tussen hoofden onderling. Bij personeelstekor- 
ten krijgen zij zelden hulp van beter bedeelde collega's. Gerversman (1963) zegt na enkele jaren ervaring als directeur-geneesheer:

"Vanuit directioneel niveau bezien, is men geneigd de hoofdverplegenden in de eerste plaats als een groep te beschouwen... De praktijk leert echter helaas vaak anders."

Het tamelijk recente verschijnsel van de gehuwde verpleegkundige plaatst het afdelingshoofd soms ook voor problemen die zij als oncollegiaal ged ragervaart, maar die door de andere partij anders worden gezien. Onpopulaire diensttijden, bv. avonddiensten, vroeg-ochtenddiensten, week-end-en feestdag-diensten worden door de huisvrouw/verpleegkundige soms geweigerd omdat zijdan haar gezin niet in de steek will laten. Dat geeft problemen, want de hoofdverpleegkundige ervaart de weigering als oncollegiaal gedrag. $\mathrm{Zij}$ moet anderen dan relatief te vaak laten inspringen.

\section{Spanningen door verwachtingen waaraan niet wordt voldaan}

De soms onuitgesproken verwachtingen van het afdelingshoofd dat verpleegkundigen hun eigen persoonlijke wensen en verlangens zullen negeren om zich totaal te kunnen wegcijferen voor de patiënten, kan de oorzaak zijn van spanningen tussen de hoofdverpleegkundige en haar staf. Strain (1978) spreekt daarover en wijst op de soms zwijgende wrok die beide teleurgestelde partijen uit elkaar drijft. Ook kunnen spanningen ontstaan door de verwachting dat verpleegkundigen handelingen zullen verrichten of erbij assisteren, terwijl die hen emotioneel of moreel blijken te bezwaren, bijvoorbeeld bij abortus en reanimatie. Als men weigert kunnen de discussies en beschuldigingen fel oplaaien.

\section{Spanningen tussen hoofdverpleegkundigen en leerlingen}

De problemen tussen hoofdverpleegkundigen en leerlingen hebben vooral betrekking op:

1. het opleidingssysteem;

2. begeleiding;

3. motivatie.

\section{Het opleidingssysteem}

Verschillende auteurs bekritiseren het huidige opleidingssysteem, zowel de in-service training als de volledige dagopleiding.

De leerlingen van de in-service-opleiding worden teveel aan tegengestelde verwachtingen blootgesteld, omdat ze twee posities hebben: die van leerling ên die van werkkracht.

De volledige dagopleiding komt aan deze bezwaren tegemoet. Ook tijdens de korte stages op de afdelingen blijven de leerlingen leerling.

Beide systemen veroorzaken echter spanningen, zowel voor leerlingen als voor het afdelingshoofd. 
Bij de in-service-opleiding liggen waarschijnlijk de meeste spanningen bij de leerling, waarop, volgens sommigen, roofbouw wordt gepleegd. Het grote verlooppercentage wijst wel in die richting. De spanningen uit het werk worden soms omgezet in agressie die wordt afgereageerd op het afdelingshoofd, dat als zondebok fungeert.

Bij de volledige dagopleiding liggen de problemen enigszins anders. Hier komer klachten zowel van hoofdverpleegkundigen als van leerlingen gelijktijdig naar voren. De hoofduerpleegkundigen klagen dat de leerlingen niet meer weten wat echt verplegen is, omdat ze te ver van de werkelijke problemen uit de praktijk staan. De leerlingen zeggen dat ze als ze gediplomeerd zijn nog niet voor vol worden aangezien en dat ze niet goed zelfstandig hebben leren werken.

Kramer (1977) heeft de processen onderzocht die pas-gediplomeerden van dagschool-opleidingen doorlopen bij hun eerste werkervaringen. Uit dit werk is het begrip "reality-shock" ontstaan. Daaronder verstaat Kramer de ontdekking dat in de school aangekweekte verpleegkundige kennis en waarden niet passen bij of in conflict komen met die van de ziekenafdeling. In vervolgstudies (Kramer en Schmalenberg (1977) en Schmalenberg en Kramer (1979) komt naar voren dat de meest doeltreffende wijze om de reality-shock op te lossen is het "bi-cultureel" worden van de zojuist gediplomeerden: het erkennen dat de opleiding uitgaat van een theoretische opstelling en dat er op de afdeling met een praktische benadering gewerkt moet worden. Omdat de theorie nu eenmaal een hogere status heeft dan het handwerk, geven "bi-culturelen" op de afdeling de hoofdverpleegkundigen het onbehaaglijke gevoel door een bedekte kritiek te worden omringd. Dat maakt hen onzeker. Sommigen compenseren dit door herhaaldelijk en nadrukkelijk op hun gelijk te wijzen.

\section{Begeleiding}

Een veel gehoorde klacht van leerlingen is dat hun emotionele problemen, voortkomend uit contacten met zieken en stervenden, door hoofdverpleegkundigen zo slecht worden opgevangen. Dit kan gedeeltelijk liggen aan onmacht wan ouderen om jongeren te begrijpen, en omgekeerd. Maar er zijn ook andere oorzaken aan te wijzen, waarom de hoofdverpleegkundige niet met de leerlingen in gesprek raakt, zoals personeelstekorten waardoor het afdelingshoofd geen tijd heeft om rustig te praten, verschil in opvattingen hoe je problemen verwerkt en soms ook jaloezie van de oudere op de jongere.

Hoofdverpleegkundigen zijn over het algemeen niet erg enthousiast te krijgen voor thun opleidingstaak. Dat is moeilijk om te buigen. Veel ziekenhuizen en opleidingsscholen hebben daarom besloten het overbezette afdelingshoofd hiermee niet langer lastig te vallen. Praktijkbegeleiders nemen een gedeelte van haar opleidingstaak over. Dat blijkt een moeilijke baan met ingebouwde conflicten, waarin na enige tijd velen afhaken. Rozema en Visser(1978) vonden dateen aanleiding om een onderzoek in te stellen naar de taak en werkomstandigheden van de praktijkbegeleiders. Hun conclusie is dat de problemen van de praktijkbegeleidingssitwatie verlegd zijn naar de positie van de praktijkbegeleiders. 


\section{Motivatie}

Hekspoor en Willems (1975) wijzen op verschillen in normen en waarden tussen de oudere en jongere generatie:

"Conflicten die zich op grond daarvan kunnen voordoen, liggen in een stuk maatschappij-opvatting, die is ontstaan na de Tweede Wereldoorlog. Arbeid betekende toen vooral hard werken en prestaties leveren. Men ging er toen wan uit dat men leefde om te werken en niet werkte om televen. De opvatting "Werken om te lewen" gaat zich in deze tijd duidelijk manifesteren. Vooral bij de jongere generatie. Dit vormt dan ook vaak de basis voor conflicten tussen ouderen en jongeren."

Deze mentaliteit botst volgens veel hoofdverpleegkundigen met de zware eisen van het verpleegkundig beroep.

Partridge (1978) verwoordt de motivatieproblemen wanneer verpleegkundigen hun eigen beroep en werk als waardeloos beschouwen (en zich identificeren met waarden en normen van andere beroepsbeoefenaren):

"Wij zijn gemangeld door het verlies van vertrouwen in onze eigen waarden en gaan professionalisatie zoeken. Maar wat is onze echte boodschap? Onze waarden, overgebracht door ons gedrag, lopen niet meer in de pas met de hulp die anderen van ons verwachten. De patiënten helpen bij dagelijkse bezigheden, zoals knopen dichtmaken, veters strikken, tanden poetsen en haren kammen wordt als minderwaardig beschouwd en de pas-gediplomeerde kent deze basisvaardigheden van het beroep niet meer. Dit is ernstig voor de patiënt die onvoldoende en soms gevaarlijke hulp krijgt. Het geeft ook een crisis in de zelf-achting van de verpleegkundige en een verlies van aanzien bij collega's, supervisors en patiënten."

Oberman (1972) meldt dat aan een verpleegstersraad van een middelgroot ziekenhuis eens de vraag werd gesteld: "Valt verplegen tegen?" De grote meerderheid antwoordde hierop met een duidelijk: "Ja".

\section{De taak- en rolopvattingen van verpleegkundigen}

Alvorens de literatuurbevindingen weer te geven over taken en rollen van hoofdverpleegkundigen, is het nuttig beide begrippen te omschrijven.

Globaal gesproken verwijst "taakopvatting" naar de technische, uitvoerende aspecten van een beroep en "rolopvatting" naar gedragsaspecten van de functionaris.

Onder taak of functies verstaan we de activiteit(en) en verrichting(en) behorend tot een beroep, positie of a mbt. Rol is het verwacht gedrag van een individu in een sociale positie of functie.

Wij wezen eerder op de verschillen tussen theorie en praktijk wat betreft taakuitoefeningen en rolopvattingen van hoofdverpleegkundigen. Ziekenhuisdirecties, opleidingsinstituten en hoofdverpleegkundigen stellen taakomschrijvin- 
gen en functie-analysen op, die indruk maken door grondigheid en gedetailleerdheid. De essentie hiervan is het volgende.

Voor de patiëntenzorg op de afdeling is de hoofdverpleegkundige de belangrijkste persoon. Zij kan bijdragen aan het opsporen van problemen van patiënten, hun noden en wensen en de mogelijke oplossingen daarvan. Zij draagt een grote verantwoordelijkheid voor de wijze waarop personen worden ingevoegd en materialen worden aangewend bij het behartigen van de patièntenzorg. De hoofdverpleegkundige heeft niet alleen invloed op de patiëntenzorgdoor haareigen directe inbreng, maar ook door middel van haar teamleden die zij leidt, onderricht en in hun werkzaamheden coördineert. Haar taak is daarom veelomwattend en behelst zowel klinische, bestuurlijke als onderrichtende aspecten.

Zij werkt ten nauwste samen met patiènten, familieleden, verschillende niveau's verpleegkundigen, specialisten en andere functionarissen. Beslissingen vanuit maatschappelijke groeperingen beïnvloeden ook haar werkterrein.

Zij kan cruciale verbindingen vormen tussen patiënten en zorgverleners, staf en directie en tussen afdelingen en de maatschappij buiten het ziekenhuis.

Door dynamische veranderingen in gezondheidszorg en maatschappelijke structuren zal de hoofdverpleegkundige het begeleiden van veranderingsprocessen als het vierde, essentiële onderdeel van haar taak beschouwen.

Waarom kunnen hoofdverpleegkundigen hun taak niet uitoefenen zoals hierboven is a angegeven?

Er zijn veel direct voor de hand liggende oorzaken zoals personeelstekorten, gebrekkige middelen, onvoldoende inzicht en te weinig klinische en bestuurlijke vaardigheden.

De literatuur geeft daarover overvloedig informatie.

Perrow (1963) noemt de bureaucratische en professionele gezagslijnen met hun conflicterende normen en waarden als één van de factoren die hoofdverpleegkundigen in hun tak kuitoefening belemmeren.

Freidson (1970) vraagt evenals Perrow aandacht voor de dysfunctionele dominantie van specialisten. Verweij (1981) wijst op de informele macht van de artsen. Stevens (1974) en Plachy (1976) noemen als oorzaak van de problemen de vele en ingewikkelde taken van het afdelingshoofd. Kennedy en Vose (1978) zeggen dat gebrek aan leiderschapskwaliteiten van het afdelingshoofd haar buitenspel zet. Zander (1977) meent dat hoofdverpleegkundigen verschillende vaardigheden missen om hun functie effectief gestalte te kunnen geven. Weisman (1980) wijst op kennisgebrek.

"What you do in the ward is not what is taught in school" zeggen Amerikaanse en Engelse leerling-verpleegkundigen én - in een vertaalde versie - hun Nederlandse collega's. De verschillen in visies op verpleging en de verpleegkundige praktijk maken de hoofdverpleegkundigen onzeker. Zij verliezen ambities voor de onderrichtende aspecten van hun functie.

Door bovengenoemde factoren kunnen afdelingshoofden hun functie niet 
uitoefenen zoals de officiële papieren voorschrijwen. Er is verschil tussen theorie en praktijk. Over de rol en taak van de thoofdverpleegkundige bestaat daardoor verwarring. Litwack (1977) zegt:

"Unless nurses and nursing educators can clearly define their role, others will define the role for them."

We zullen bovenaangehaalde (en nog niet genoemde) belemmeringen in een overzichtelijke samenvatting weergeven. Het gaat om:

- organisatiestructuren van het ziekenhuis;

- rolopvattingen;

- afspraken over taakverdeling;

- man-vrouw relatie;

- kennis;

- vaardigheden.

\section{Organisatiestructuren van het ziekenhuis}

Het Engelse Salmon-report (1966) stelt voor het ziekenhuis meer hiërarchisch te structureren. Veel Engelse ziekenhuizen brachten deze aanbeveling in praktijk. Ook Nederlandse ziekenhuisstructuren gingen zich pyramidevormig ontwikkelen. Daardoor krijgen hoofdverpleegkundigen meer hiërarchische chefs boven zich. Het blijkt dat dit problemen geeft in werkmotivatie, besluitvaardigheid, communicatiemogelijkheden, beleidsontwikkelingen en werktevredenheid.

Coser (1971) schrijft:

"Lange, enge hiërarchieën zijn niet gunstig om bij werkers efficiëncy en arbeidsethos te bevorderen. In zulke organisaties zijn mensen niet in staat te ontdekken waar hun sterke en zwakke kanten liggen."

Verweij (1981) wijst ook op de ziekenhuisstructuren als belemmeringen voor het werk van de hoofdverpleegkundige. Zij richt haar bedenkingen niet zozeer op de pyramide- maar op de functiegerichte structuren. Ook wij hebben daa rop gewezen. Op blz. 19 en 22 is de structuur van het ziekenhuis schenatisch weergegeven. Verweij wijst op de problemen die ontstaan in zo'n functiegerichte organisatie. Die liggen vooral op het coördinerend vlak, bij informatieverwerking, besjuitvorming en overbelasting van formele verticale communicatiekanalen. Vooral het middenkader komt hierdoor in een moeilijke positie.

Omdat de structuur van het ziekenhuis is verzuild en niet is gecentreerd rondom de patiënt komen zij, die zich in de dagelijkse praktijk op patiënten moeten richten en niet op zuilen, zélf in de problemen.

\section{Rolopvattingen}

Bergman (1981) besteedt aandacht aan de vraag: "Hoe zien hoofdverpleegkundigen en hun medewerkers de taak van het verpleegkundig afdelingshoof d?"

$\mathrm{Zij}$ wertelt dat de rol van de hoofdverpleegkundige ter sprake kwam op een interdisciplinaire studiedag in Israël. Er werd geen overeenstemming bereikt. Een 
grote groep verpleegkundigen was van mening dat de hoofdverpleegkundigen zich alleen met verpleegkundige problemen mochten inlaten en dat niet-verpleegkundige problemen aan niet-verpleegkundige managers moesten worden toevertrouwd. Een andere groep zag de hoofdverpleegkundige als een moeder-vervangend persoon, wier taak daarop moest worden afgestemd.

De American Nurses" Association (ANA 1978) zegt dat de belangrijkste taak van de hoofdverpleegkundige ligt in het begeleiden van het verpleegkundig personeel bij de uitvoering van verpleegkundige hulpverlening.

Het Salmon-report (1966) beschouwt de hoofdverpleegkundige als de coördinator van het team dat hoe langer hoe heterogener wordt. Het Briggs report (1972) dat daarop volgde, constateert dat hoofdverpleegkundigen meer administratief gericht zijn dan vroeger. Het zegt dat hoofdverpleegkundigen niet bereid zijn deze taken af te stoten omdat zij vrezen daardoor hun grip op de afdeling te verliezen.

Bergman (1981) noemt verschillende auteurs die rolgedrag van (hoofd) verpleegkundigen bestudeerden. Sommigen wijzen op een gering management-bewustzijn van afdelingshoofden.

Studies over individuele rolopvattingen van hoofdverpleegkundigen zijn schaars. Enkele spreken over de relatie tussen karakterkenmerken en rolopvattingen (zie blz. 39). Zo zeggen ook sornmige informanten dat hoofdverpleegkundigen van chirurgische afdelingen andere karakterkenmerken en rolopvattingen hebben dan hun collega's op interne afdelingen. Bepaalde karakters zouden zich tot bepaalde specialismen aangetrokken voelen, maar anderen bestrijden dit weer. Zij zeggen dat de stijl van leiding geven van specialisten de rolopvattingen van hoofdverpleegkundigen beinvloedt.

\section{Afspraken over taakverdeling}

Verweij (1981) wijst op de geringe stabiliteit in de personele bezetting van verpleegafdelingen. Hierdoor is het moeilijk langdurige afspraken over taakverdeling te maken. Onduidelijkheid in wat artsen en werpleegkundigen van elkaar mogen verwachten, leidt tot onzekerheid van het afdelingshoofd en tot slechte patièntenzorg. In een onderzoek van Habeeb (1977) komt naar voren dat verpleegkundigen bepaalde gedeelten wan hun taak laten liggen, omdat zij niet weten of dat werk van hen word verwacht. Ook houden zij zich soms afzijdig van taken, omdat medici zeggen die te zullen uitvoeren, terwijl zij dat dan niet of nauwelijksdoen. Dan koml de zieke in een vacuüm terecht. Het inlichten van patiënten kan bijvoorbeeld zo mislopen. De Bruyn (1979) haalt als illustratie hiervan een onderzoek aan datenkele jaren geleden in Rotterdam is gehouden, waarin men aantoonde dat patiënten soms meer dan een week in een ziekenhuis liggen, zonder duidelijk te weten waarvoor ze er liggen en wat er met hen gebeurt.

Hoofdverpleegk undigen zeggen dat de ziekenhuisdirectie en specialisten hen soms im het ongewisse laten over hun bevoegdheden.

Ook de groep verpleegkundigen als geheel is onzeker. "De verpleegkundigen zélf kunnen hun beroep niet meer omschrijven", aldus Abdellah (1960), één van de lei- 
dende figuren in de Amerikaanse verpleging. Ruim lwintigjaren later zijn we nog niet weel verder, zie bijvoorbeeld een uitspraak van Styles (1981):

"We zijn een professie die zoekt naar zijn identiteit. We zijn op zoek naareen wijze van denken over ons domein."

\section{Man-vrouw relatie}

"Een fundamenteel problem ligt", aldus Hoekelman (1975), "in het feit dat de meeste artsen mannen zijn en verpleegkundigen vrouwen. Hun relaties zijn vaak een zuiver voorbeeld van de mannelijke uitbuiting van vrouwen. Maar verpleegkundigen zijn zich aan het emanciperen en veranderen hun ondergeschikte rol in die van gelijkheid met de mannen."

Sommige auteurs zeggen dat door mannelijke dominantie bepaalde waardehièrarchieën ontstaan die lang niet altijd aansluiten bij die van patiënten of verpleegkundigen. Baumgart (1981) is een van hen:

"Mannelijke gezichtspunten bepaalden welke gezondheidsproblemen als belangrijk moeten worden beschouwd. Hun visie op de gezondheidszorg gaf beslissende impulsen. Deze situatie veroorzaakte een onderwaardering van verpleegkundige gezichtspunten en kennis."

In het ziekenhuis geldt de ongeschreven etiquette die bepaalt dat verpleegkundigen slechts op een subtiele en verkapte manier initiatieven mogen ontplooien.

\section{Kennis}

Kennis is macht, maar macht bepaalt óok wat kennis is en wat medici en wat verpleegkundigen tot hun respectieve terrein mogen rekenen. Pasteur en Röntgen waren geen artsen, maar medici claimden hun kennis als behorend tot hun gebied. Diëtisten en fysiotherapeuten hebben hun eigen, zelfstandige opleiding, maar specialisten schrijven voor. Sommigen spreken van medisch imperialisme. De medici hebben bezwaar gemaakt tegen lset ontstaan van verpleegstersopleidingen. Bernard en Thompson (1966) wijzen op:

"The old fashioned physicians belief that the hospital servant is the best type of nurse and that nursing, if advanced to a profession, would compete with medicine."

De verpleegstersopleidingen die tóch startten werden door artsen gedomineerd. Zij stelden het lesprogramma op; daarin werd niet de mens, maar de ziekte behandeld. De opleiding werd een aftreksel van een medische opleiding; aan specifiek verpleegkundige kennis werd geen aandacht besteed.

Tegenwoordig zijn de verpleegk undige inzichten verder uitgebouwd. Overigens óok weer een bron van zorg voor sommige auteurs en onderzoekers, die de kloof tussen medische en verpleegkundige kennis zorgwekkend vinden. Verweij (1981) is een van hen. Zij zegt:

"Voor een integrale patiẻntenzorg in het ziekenhuis en om de psycho-sociale zorgkanten van de verpleging beter totzijn recht te laten komen, zal het verpleegkundig 
kader cen grotere kennis van ziektebeelden moeten hebben dan nu het geval is." Met deze stelling zijn wij het in zijnalgemeenheid net eens. De verpleegkundige hoeft niet precies alles te weten wan een ziekte - daarvoor is de medicus er - maar wel moet zij weten hoe cen patiënt met die zickte te verplegen. Dat is haar eigen verantwoordelijkheid en unieke bijdrage.

\section{Vaardigheden}

De leiderschapsvaardigheden van het afdelingshoofd worden door verschillende auteurs als te klein genoemd.

Zander (1977) ziet de hoofdverpleegkundige vooral als "trouble-shooter" (iemand die overal raad op weet), Boccussie (1979) twijfelt aan haar flexibiliteit om dat effectief uit te woeren. Sommigen zeggen dat dit komt doordat het afdelingspersoneel te weinig achting voor het hoofd opbrengt. Daardoor moeten zij vaak en nadrukkelijk op hun recht gaan staan. Boccussie (1979) wijst op noodzaak van onderhandelingsbek waamheden:

"De effectieve verpleegkundige leider gaat naar de onderhandelingstafel, goed voorbereid, praktisch gericht en met verfijnde tafelmanieren. Zij zal zich bewust zijh wan de kracht van non-verbale communicatie. Zij dient een goed inzicht te hebben in onderhandelingsprocessen en haar rol daarin."

\section{Samenvatting}

De literatuur zegt weinig over kenmerken van hoofdve rpleegkundigen of over welke eigenschappen zij dienen te beschikken.

Onderzoekingen over relaties en spanningen tussen afdelingshoofd en verpleegkundigen bieden meer aanknopingspunten.

Deze spanningen tussen hoofd en verpleegkundige medewerkers zijn o.m. te herleiden tot: personeelstekorten, niet realistische verwachtingen, slechte werkcondities, gebrek aan duidelijke doelstellingen en aan goede stirmulansen en slechte collegiale verhoudingen.

Slechte werkcondities bevorderen arbeidsontevredenheid, wantrouwen en een gevoel van machteloosheid om aan redelijke normen te beantwoorden. De bereidheid van de werker om offers te brengen voor doelstellingen die nie tof moeilijk bereikt kunnen worden, neemt af. De sfeer wordt oncollegiaal en men laat onplezierig werk voor anderen liggen. De hoofdverpleegkundige moet dan een onevenredig grote druk uitoefenen om patiëntenzorg te behartigen.

Gebrek aan stimulansen kan apathie, verzuim en verloop bevorderen. Saai en eentonig werk dagen verpleegkundigen weinig uit om intrinsieke doelen te stellen en na te streven.

Wanneer afdelingshoofd en verpleegkundigen elkaars opvattingen niet goed kennen, kunnen gemakkelijk teleurstellingen ontstaan. Ook niet realistische verwachtingen kunnen gevoelens kwetsen. 
De spanningen tussen hoofdverpleegkundigen en leerlingen zijn o.m. te hetteiden tot opleidingsproblemen, begeleidingseisen en verschillen in motivaties. De opleiding kan gevolgd worden aan een zelfstandige opleidingsschool of aan ziekenhuisgebonden cursussen. Beide hebben voor-en nadelen. De in-service-training (ziekenhuisgebonden) is erg zwaar voor leerlingen. Ze zijn werkkracht én student. Het verloop is daarom groot.

De opleiding aan zelfstandige scholen ondervangt dat bezwaar. Een kloof tussen theorie en praktijk is het voornaamste nadeel wat aan dit systeem kleeft. De begeleiding van leerling-verpleegkundigen is een taak die het afdelingshoofd vaak aan praktijkbegeleiders delegeert. Het lijkt erop dat goede oplossingen nog niet zijn gevonden.

Sommige afdelingshoofden klagen over vermindering van motivatie onder jonge mensen.

De taak van hoofdverpleegkundigen richt zich op vier essentiële onderdelen: klinisch, bestuurlijk, onderrichtend en verandering-begeleidend. $E r$ is een duidelijk verschil tussen theoretische en praktische taak-en rolopvattingen van hoofdverpleegkundigen. Door veel verschillende oorzaken kunnen afdelingshoofden hun taak niet uitoefenen, zoals theoretisch wenselijk is. Enkele daarvan zijn: organisatiestructuren van het ziekenhuis, verschillende rolopvattingen en rolverwachtingen, de man-vrouw relatie die de vrouwelijke hoofdverpleegkundige te weinig zelfstandigheid toestaat, gebrek aan kennis en valardigheden en spanningen veroorzaakt door leerlingen-verpleegkundigen en hun opleiding.

\subsection{De patiënten}

"We zijn verziekt" zegt Hattinga Verschure (1982) in een interview over de Nederlandse gezondheidszorg. Hij wijst op de gigantische kostenstijging en het afnemen van de behandelingskwaliteit. De patiëntenzorg is na de Tweede Wereldoorlog geïndustrialiseerd. "Aan de patiènt als mens heeft niemand een boodschap, daar zijn geen tarieven voor."

Tijdschriftartikelen, krantekoppen, onderzoeksverslagen en patiëntenverenigingen vertellen reeds lang dat er iets mis is met de benadering en opvang van patienten. Welke klachten komen meestal naar voren? Vier thema"s worden herhaaldelijk besproken:

- aandacht voor de patiënt;

- informatie aan de patiënt;

- beslissingsvrijheid van de patiënt;

- respectvolle behandeling van de patiënt.

In deze volgorde zullen enkele literatuurbevindingen worden aangehaald. Wij willen zoeken naar antwoorden op de vraag: "Vanuit welk gezichtspunt kan de situatie van patiënt én hulpverlener het beste worden bekeken? Welke invloed heeft de huidige patiëntenbenadering op het werk en het functioneren van (hoofd)verpleegkundigen?" 


\section{Aandacht voor de patiënt}

Uit cen enquete, gehouden door studenten van het sociaal hoger onderwijs Friesland te Leeuwarden en de Werkgroep gezondheidszorg Smallingerland (1982), blijkt dat 71 procent van de ondervraagde patiënten vindt dat specialisten te weinig aandacht aan hen besteden. De respondenten zeggen dat de artsen bijvoorbeeld te weinig wertellen ter voorbereid ing op een operatie of onderzoek. Balint (1972) die onderzoek verrichtte naar de werkelijke klachten van patiënten, zegt dat iedere zieke dringend wraagt om liefde en aandacht. Sommigen worden ziek om zich te werzekeren van aandacht en zorg.

Thung (1972) schrijft:

"Mens zijn moet bij herhaling vertwijfeling betekenen, angst en onzekerheid omtrent eenvoudige alledaagse dingen en omtrent de fundamentele rechtvaardiging van ons bestaan. Om hierin opgevangen te worden, moeten wij bij herhaling ziek worden. Op welke andere wijze kunnen wij tot onze medemensen roepen en rekenen op antwoord?"

Hoe reageert ziekenhuispersoneel op deze impliciete hulpvraag? Stockwell (1972) verrichtte in Engeland bij verpleegkundigen een onderzoek naar kenmerken van populaire en impopulaire patiënten. Centraal stond de vraag: "Waarom helpen verpleegkundigen graag bepaalde patiënten?" Juist het gedrag dat Balint en Thung aanwijzen als de uiting van de essentiële hulpvraag, blijken verpleegkundigen thet "lastige patiëntengedrag" te noemen.

MacGregor (1960) schrijft over stereotype verwachtingen van verpleegkundigen omtrent de wijze waarop patiënten zich dienen te gedragen. De goede patiënt houdt zich aan voorgeschreven regels, behandeling, verpleging en revalidatieprogramma. Hij doet dit zonder veel vragen te stellen en zonder veel tegenwerpingen. Hij vraagt niet veel aandacht; is redelijk coöperatief, probeert zijn ziekte of aandoening sportief op te vatten en tracht zoveel mogelijk zichzelf te helpen. Hij is dankbaar voor hetgeen voor hem wordt gedaan.

De moeilijke patiënt is diegene die slecht samenwerkt. Hij vraagt steeds naar het naadje van de kous en kritiseert behandeling en werzorging; nógerger, hij zegt méér te weten van zijn ziekte dan medicus en verpleegkundigen. Hij gedraagt zich emotioneel en klaagt continu en luidkeels. Hij moppert over de voeding. Hij is intolerant en een voortdurende bel-drukker. Hij toont zich zelden dankbaar.

De observaties van Schadee en Pool (1981) in een Nederlands ziekenhuis zijn wat genuanceerder. Zij herkennen ook de lastige/leuke patiënten-filosofie op de afdeling. Maar verpleegkundigen reageren subtieler. Zij schrijven:

"Hoewel deze patiënt de verpleging vaak onheus bejegende, werd hij niet als.

"lastig" beschouwd, maar als iemand met een ernstig probleem (jonge man met cen arm-amputatie) hetgeen als geldig excuus gold voor zijn obstinaat gedrag. De verpleegkundigen voelden het als een tekortkoming dat zij niet in staat waren geweest hem voldoende te helpen."

Wat is de reactie van specialisten?

Thung (1972) zegt: 
"Zoals de patiènt openlijk om genezing vaagt, maar heimelijk om eeuwig heil, zo antwoordt de geneeskunde openlijk met hulp en heimelijk met tirannieke geldingsdrang."

Hattinga Verschure (1981) deelt die mening. Hij zegt dat de opvang die de zieke en zijn omgeving in menselijke zin broodnodig hebben, veelal niet van de medische specialisten verwacht mag worden. De auteur is pessimistisch over toekomstige ontwikkelingen. Volgens hem zal de medische professie onder allerlei voorwendsels niet meewerken aan zorgvernieuwing en zal - desnoods met grote kracht - vegenwerken. Hoj zegt dat de weinige artsen, die moedig genoeg zijn en helder inzien waar het aan schort, nu reeds worden bestempeld als dissident of alternatief.

Smith en Gipps (1966) spreken over de wrevel bij Amerikaanse artsen en verpleegkundigen als zieken hun psychologische problemen niet duidelijk in organische klachten vertalen. "Crock", "zeur", is in het Amerikaanse ziekenhuis de naam voor patiènten die niet in het medisch model passen en die binnenskamers aan de kant worden gezet.

\section{Informatie aan de patiënt}

"Patiënten in een ziekenhuis hebben niet de garantie dat zij woldoende worden ingelicht over hun ziekte, de behandeling en de medicijnen die zij krijgen. Vaak is wat ze te horen krijgen doorspekt met onbegrijpelijke medische termen," aldus de uitkomst van een enquête van de Consumentengids (1978) onder 572 exziekenhuispatiënten. Eénderde van de ondervraagden is ontevreden. Ze kregen te weinig informatie over bijvoorbeeld bezoekuren, regels en recreatie. De ondervraagden klagen ook over het feit dat ze niet rustig met een arts kunnen praten. Een witte wolk van zusters en co-assistenten omringt de specialist. Hoe kun je dan over privé-problemen spreken?

De klachten over communicatie en informatieuitwisseling zijn zo frequent dat de overheid zich ermede gaat bemoeien. De voormalige staatssecretaris van Volksgezondheid en Milieuhygiène, Veder Smit (1981), verantwoordt haar belangstelling voor de positie van de patiënt met de opmerking dat de gezondheidszorg maar ten dele wordt gekenmerkt door een vrij krachtenspel van vraag en aanbod, waardoor scheefgroei niet voldoende kan worden gecorrigeerd. Zij legt de nadruk op vier terreinen waarop de overheid zich in eerste instantie dient te richten: patièntenvoorlichting, patiëntenparticipatie, patiëntenorganisatie en patiëntenrecht.

\section{Beslissingswrijheid van de patiënt}

Op het symposium van de Erasmus Universiteit te Rotterdam - "informed consent" - blijkt, dat niet alleen de informatie aan patiënten te wensen overlaat. Ook de beslissingsvrijheid van patiënten wordt ingeperkt.

Tijdens een discussie met artsen kwam bijvoorbeeld aan het licht dat velen onder hen tijdens hun opleiding het rectaal en vaginaal toucheren leren bij vrouwen onder narcose, zonder then tevoren om toestemming te vragen. "Het is bij de wilde spimnen af, dat mensen zoiets zonder toestemming doen", zegt de Leidse ethica TerborghDupuis (1982). De jurist Dekkers voegt eraan toe dat zulke handelingen in het 
normale verkeer strafbaar zijn. De voorzitter van de Vereniging voor Gezondheidsrecht, Leenen (1982), zegt dat de patient een zwakke positie heeft in de gezondheidszorg. Tijdens de vergadering met mimister Gardeniers dringt de vaste Kamercommissie voor Volksgezondheid erop aan dat de rechten van de patient met spoed worden geregeld.

Beslissingen over overplaatsing, therapie en zelfs reanimatie worden niet zelden zonder inspraak van zieken genomen.

Anderzijds kunnen patiënten of famillie niet altijd de gevolgen begrijpen van medisch handelen of het staken daarvan. Dan kunnen artsen voor grote problemen komen. Op een in Parijs gehouden ronde-tafelgesprek van medici, biologen, sociologen en theologen uit verschillende landen is de wens uitgesproken om te komen tot een internationaal "medisch geweten". De achtergrond hiervan is de tweestrijd waarin artsen kunnen belanden door nieuwe ontwikkelingen.

\section{Respectvolle behandeling van de patiënt}

De Jong (1982) voorzitter-medicus van de centrale plangroep kwaliteitsbevordering meent dat artsen zich te weinig bekommeren om de leefwereld van de patiënt; een klacht die vaak wordt geuit. Vooral de afstandelijkheid en ongenaakbaarheid van de behandelaars en verzorgers worden vaak genoemd.

Het gezondheidsinstituut kweekt, aldus Goffman (1963), door voorschriften, geboden en verboden een situatie waarin patiënten en verzorgers in twee afzonderlijke groepen worden gescheiden.

Bremer (1973) wijst ook op die gescheiden werelden waardoor begrip en respect voor elkaar afnemen.

Howard (1976) spreekt over de ongelijkheid tussen patiënten en behandelaars. Dit tast bij patiënten de zelfachtingaan. Zij gaan zich als dingen beschouwen en verliezen weerstand tegen de ontmenselijking.

"Gedepersonaliseerde mensen worden beschouwd als onbezielde, gevoelloze objecten of machines, die kunnen worden gemanipuleerd, waarmee kan worden geëxperimenteerd, die gefragmenteerd kunnen worden in problemen en afstandelijk behandeld. In meer extreme gevallen worden zij geïsoleerd, vervreemd en ontdaan van waardigheid. Zij hebben weinig mogelijkheden om te ontsnappen aan hun statische, steriele, ontluisterende omgeving. Hun behandeling is vaak gestandaardiseerd in overeenstemming met de maatschappelijke kijk op hun geringe waarde. Zij krijgen geen zelfbeslissingsrecht over leven en dood."

\section{Centraal probleem}

Wat is de kern van de problematiek die uit de literatuurstudie naar boven komt? Wat ligt ten grondslag aan de geringe aandacht voor de patiënt, de gebrekkige informatie, het gemis aan autonomie en beslissingsvrijheid?

Wat is de rationale waardoor de positie van patiënt én verplegende als directe hulpverlener die aan de kant van de zieke staat het beste wordt begrepen?

Het beste kan men begrip krijgen voor de positie van de patiënt - en voor de verple- 
gende, die zich trachtals advocaat van hem op te stellen-door hem te beschouwen als een mens ingeklemd tussen twee werelden.

De patiënt heeft een ziekte en is daarvoor naar het ziekenhuis gekomen. De behandeling wordt voor hem uitgestippeld door de medici, die hem op technisch-rationele manier proberen te helpen. De patiënt leeft ook in zijn eigen wereld, met problemen, die weliswaar verband houden met zijn ziekte, maar toch een eigen, anderssoortig karakter hebben.

Terwijl de arts zich bezighoudt met de vraag of de ziekte bedwongen wordt, houdt de patiënt zich wooral bezig met de gevolgen van zijn ziekte; hij heeft angst voor de dood of voor decorumverlies, voor pijn en ongemak.

De zieke spant zich in om de medici ook voor deze patiëntproblemen te interesseren, maar theeft daarmee soms moeite. Allesoverheersend in het ziekenhuis is - we zagen dat reeds eerder - het medische model. Hoe de patient zijn ziekte beleeft en er op reageert is wan een andere, minder belangrijke orde.

De verpleging - die als eigen kenmerkende inbreng heeft het opkomen voor de gevolgen van de ziekte - prikt daar ook niet doorheen. Zij heeft te weinig macht om het patiëntenbelang een evenwaardige plaats te bezorgen, want de verpleging is zelf evenzeer slachtoffer van de huidige structuren.

\section{Gevolgen}

De overheersing van het medisch-technisch handelen dringt zelfs ongemerkt de verpleging binnen, en berooft deze discipline van zijn meest wezenlijke kenmerk: het behartigen van de patiëntenbelangen.

(Hoofd)verpleegkundigen zien dat de ware problemen van patiënten niet worden behandeld. Zelf kunnen ze - zonder medewerking van de medici- niet wezenlijk iets veranderen.

De patiënt gaat zich afreageren door te klagen over zaken die in feite met zijn ziekte en verwerking daarvan niets te maken hebben: voeding, recreatie, bezoektijden. De verpleegkundigen verschansen zich op den duur achter het medisch denken en sluiten zich emotioneel van de patiënten af. Hierin schuilt het grootste gevaar dat de verpleging bedreigen kan: het verliezen van de eigen identiteit.

\section{Samenvatting}

Ziekenhuiswerkers, maatschappelijke groeperingen en overheid zeggen dat de patiënt als méns in het ziekenhuis tekort komt.

Ervaren medici spreken van de zieke als zoeker naar liefde en aandacht. Uit Engels/Amerikaans onderzoek blijkt dat het zoekende ziekenged rag door verpleegkundigen als lastig wordt omschreven. De patiënt die om hulp vraagt, maar zijn emotionele klachten niet in lichamelijke symptomen kan vertalen worden "crock" (zeur) genoemd. De prettige ziekenhuispatiënt stelt - volgens verpleegkundigen niet veel vragen, gedraagt zich beheerst en correct, coöperatief en dankbaar. 
Onderzoekers in Nederlandse ziekenhuizen geven een genuanceerder beeld wan verpleegkundige opvattingen over patiënten.

Medici uiten kritiek over de wijze waarop collega's patiënten benaderen. Positieve geluiden over toekomstige verbeteringen zijn schaars.

Communicatie en informatie-uitwisseling tussen hulpverlener en hulpzoeker voldoen niet aan verwachtingen van de zieken. Auteurs spreken over twee van elkaar gescheiden werelden waar vakjargon en vreemde gewoonten zieken het gevoel geven in een ander land te leven.

Medische opleidingen kweken super-individualistische artsen, niet gewend te reflecteren op eigen handelen. Daarom is de medische kijk soms eenzijdig en vertekend. De ongelijke verhoudingen tussen patiënten en ziekenhuispersoneel beperken de beslissingsvrijheid en besluitworming van de hulpvrager. Hoe méér verzorgers de patiënten als gelijken zien, hoe meer zij geneigd zullen zijn de patiënt bij de besluitvorming te betrekken.

Zowel kennis alls onkunde van specialisten beletten hen soms informatie te geven aan patiènten of ouders. De wetenschap dat een therapie mogelijk is, en de ongewisheid ower de resultaten ervan doen hen soms aarzelen.

De gevolgen van de "twee-werelden" situatie in het ziekenhuis zijn niet alleen ernstig voor patiènten, maar ook voor verpleegkundigen.

Hoofdverpleegkundigen ervaren de teleurstelling en soms de wrok van patiënten. Dat tast hun werktevredenheid aan. Bovendien richten patiënten hun ontevredenheid over behandeling soms op de verzorging. Door stagnerende communicatie en onvoldoende informatie worden ook verzorgers belemmerd de wereld vanuit de zieken te bekijken. Dan sluiten zij zich emotioneel van patiënten af en verliezen hun integriteit t.o.v. hen. Als zij zieken als minder menselijk beschouwen, functioneren behandelaars en verzorgers zélf minder als mens. 


\section{Hoofdstuk 3}

\section{Vraagstellingen voor het hoofdonderzoek}

Uit de literatuurstudie komen werkproblemen van de hoofdverpleegkundigen naar voren, waarvan vele een nadere bestudering rechtvaardigen.

Omdlat in Nederland op dit terrein nog weinig research is verricht, werd in eerste instantie besloten tot een exploratief onderzoek met een zo breed mogelijke orièntatie.

De aanvankelijke basis-vraagstelling: "Welke belemmeringen ontmoet de hoofdverpleegkundige bij de uitoefening van haar taak?" (hoofdstuk 1, pag. 13) menen wij door literatuuronderzoek enigszins te kunnen beantwoorden.

Voor het empirische, exploratieve onderzoek herformuleerden wij de basisvraag als volgt: "Waarom hebben hoofdwerpleegkundigen deze werkproblemen?" Een aantal sub-vraagstellingen richtte de aandacht op concrete zaken zoals: intermenselijke verhoudingen, personeelsbeleid, kenmerken van hoofdverpleegkundigen e.d..

Dit onderzoek is inmiddels voltooid en in twee rapporten verwerkt (Van den BerghBraam 1982, 1983).

Uit de beschikbare gegevens willen wij nu één onderwerp selecteren en dat intensief analyseren. Door ons tot slechts enkele kernvariabelen te beperken, hopen wij een meer indringend beeld te krijgen van een deelterrein. Het criterium van maatschappelijke en theoretische relevantie zal bij de probleemkeuze een rol spelen.

In dit hoofdstuk zullen we eerst het terrein afbakenen (3. 1 ) en daarna het conceptuele kader aangegeven waarbinnen deze studie zich beweegt (3.2). Vervolgens zullen wij summier de theoretische achtergrond belichten (3.3), waarna een literatuursamenvatting volgt, gericht op de gekozen probleemstelling(3.4). In 3.5 tenslotte worden de vragen geformuleerd, waarop wij in deze studic een antwoord trachten te vinden, waarna 3.6 het hoofdstuk samenvat.

\subsection{Probleemkeuze}

Bij het doornemen van de gegevens valt herhaaldelijk op hoe dikwijls de werkbelasting van hoofdverpleegkundigen ter sprake komt. Velen noemen dat de belangrijkste stressfactor. Als wij aan hoofdverpleegkundigen vragen (Van den Bergh-Braam 1981) wat hun de meeste spanningen geeft, antwoordt 59 procent van hen: "Het zorgdragen voor een adequate personeelsbezetting." Als de afdeling gebrek atan personeel heeft gaan hoofdverpleegkundigen vaak zelf inspringen, waardoor hun eigenlijke taken bijiven liggen. "Je probeert zoveel mogelijk te redden. Dan letten wij er vooral op dat verpleegkundigen niet in paniek raken."

Een tweede, veel geciteerd, probleem is de rolonduidelijkheid van afdelingshoofden. 
Hoofdverpleegkundigen wragen zich af: "Waar liggen mijn bevoegdheden en verantwoordelijkheden? Wat verwacht het afdelingspersoneel van mij? Moet ik de patiënt al of niet inlichten over de ernst van de ziekte, of zal de arts dit doen? Wie bepaalt hier eigenlijk de gang van zaken?"

Ook al hebben enkele afdelingshoofden een taakbeschrijving, dan nog blijken er bepaalde onduidelijkheden te blijven bestaan. Als reden geeft men op dat ze verouderd en niet aangepast aan de huidige situatie zijn en dat het onmogelijk is om details te regelen. Sommigen wijzen erop dat bepaalde personen en groepen zich niet willen inpassen.

Tussen beide onderwerpen dienen wij een keuze te maken. Als wij voor werkbelasting kiezen, dan staan wij meteen voor het probleem van het objectiveren van meningen. Als hoofdverpleegkundigen klagen over te weinig personeel, hoe juist is dat, objectief beschouwd?

Wij kunnen deze vraag trachten te beantwoorden met behulp van de personeelsratio: het aantal personeelsleden per patiënt. Daar de personeelsratio alleen echter een te zwakke indicatie vormt voor werkbelasting van hoofdverpleegkundigen en er geen andere, aanvullende objectieve criteria beschikbaar zijn, zijn wij genoodzaakt het onderwerp werkbelasting te laten varen.

Anders ligt dit met de rol (on)duidelijkheid van hoofdverpleegkundigen. Daarvoor kunnen meer gegevens worden verzameld buiten de subjectievesfeer. Dit kunnen wij o.a. bereiken door aan hoofdverpleegkundigen én aan hun directe medewerkers een aantal wragen te stellen met betrek king tot de werkzaamheden en andere rol relevante variabelen van hoofdverpleegkundigen.

Wanneer de meningen van hoofdverpleegkundigen én medewerkers met elkaar corresponderen, bestaat er rolduidelijkheid. Verschillen de opinies, dan is ersprake van rolonduidelijkheid, die groter wordt naargelang de meningen frequenter en sterker divergeren.

Vanwege de mogelijkheid rol(on)duidelijkheid minder subjectief te kunnen meten dan werkbelasting, kiezen wij in dit onderzoek voor een nadere ana lyse van rolonduidelijkheid van hooldverpleegkundigen.

Het onderwerp dat onze voorkeur heeft is duidelijk maatschappelijk en theoretisch relevant.

De matschappelijke betekenis van een onderzoek naar rolonduidelijkheid bij hoofdverpleegkundigen ligt in het feit dat onzekerheid over het functioneren oorzaak kan zijn van spanningen, conflicten, gezondheidsklachten en onvoldoende patiëntenzorg. Als verbanden aangetoond kunnen worden tussen bovengenoemde verschijnselen, wordt het mogelijk maatschappelijk nuttige stappen te ondernemen om de problemen op te lossen.

De theoretische relevantie ligt in het feit dat de bevindingen van dit onderzoek - dat zich baseert op twee uitgangspunten, het stress-model en rol-theoretische achtergronden - vergeleken kunnen worden met andere stress-onderzoeken en mogelijk een bijdrage leveren aan de rol-theoretische research. 


\subsection{Het conceptueel kader: het stressmodel}

Het begrip "stress" is afkomstig uit de technische wetenschappen. Het verwijst naar een externe druk (stressor) die op een object wordt uitgeoefend en daar storingen (strains) veroorzaakt.

De Canadese endocrinoloog Hans Selye introduceerde de term stress in de biologische en medische wetenschappen. Stress wordt door hem omschreven als een toestand die zich manifesteert in een bepaald specifiek syndroom, dat bestaat uit alle niet specifiek veroorzaakte veranderingen in een biologisch systeem. Dit syndroom noemt hij het General-Adaptation-Syndrome (G-A-S).

Het G-A-S kent drie stadia:

- De alarmreactie, een fase van verminderde activiteit (shockfase) die wordt gevolgd door excessieve mobilisatie van krachten (tegen-shock-fase). Hierbij is nog geen sprake van een aanpassing aan de bedreiging. In dit stadium kunnen fysiologische veranderingen optreden, bijvoorbeeld lagere lichaamstemperatuur, verhoogde afgifte van adrenaline enz..

- De weerstandreactie. In dit stadium streeft de mens naar een aanpassing aan de waargenomen bedreiging. De lichamelijke veranderingen die typerend waren voor de alarmreactie verdwijnen.

- De uitputtingsreactie. Indien de stressor aanhoudt kan de energie voor de aanpassing verloren gaan. Dan breekt de weerstand.

Selye noemt het syndroom "algemeen" omdat het geen specifieke, bijzondere oorzaak heeft; alles kan dit syndroom oproepen.

Het is "adaptief" omdat de stressreacties de functie vervullen het verstoorde evenwicht te herstellen. Het is een "syndroom" omdat het niet één, maar een onderling samenhangend geheel van veelsoortige reacties is.

Het G-A-S kan echter tengevolge van inadequate adaptieve reacties van het lichaam resulteren in een zogenaamde "disease of adaptation", bv. een maagzweer en een hartinfarct.

Stressverschijnselen zijn onderzocht vanuit verschillende disciplines als fysiologie, psychologie, sociologie en geneeskunde. Het feit dat zovelen zich met stressonderzoek bezighouden heeft eerder tot verwarring geleid dan tot verheldering van inzichten.

Binmen het Instituut voor Sociale Research (ISR) te Michigan (opgericht door Kurt Lewin) hebben met name Kahn, French en Cobb (1974) een onderzoeksmodel uitgewerkt dat als leidraad kan dienen bij stressonderzoek. Kenmerkend voor deze onderzoekers is dat zij een duidelijk onderscheid maken tussen objectieve omgeving en subjectief waargenomen omgeving. Het ISR-model is overigens breed van opzet. Het is in feite meer bedoeld als een samenvoeging van een aantal begrippen dan als een representatie van een theorie. Het model wordt beperkter als binnen de kaders begrippen worden ingevuld en veronderstelde relaties worden geformuleerd.

Caplan et al (1975) gebruikten dit onderzoeksmodel in organisatiestudies. De vra- 
genlisten die zij darbij hanteerden werden in enigszins gewijzigde vorm in ons onderaek gebruikt (VOS-list, zie hoofdstuk 4).

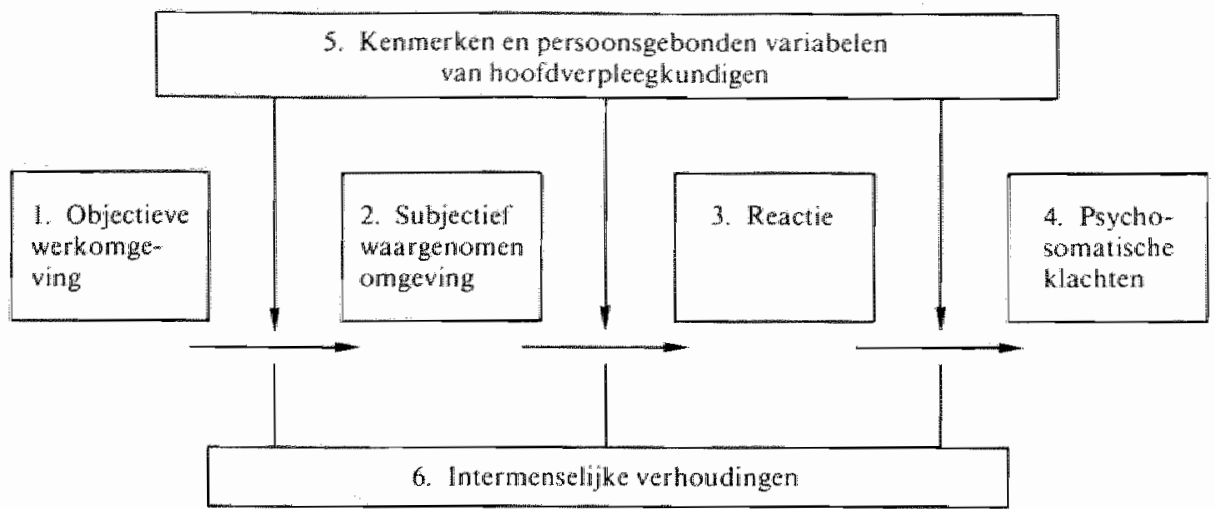

Figur 4. Het ISR-model. Uit: The social psychology of organization, 2ed., Chapter 17. Work and beath. Katzand Kahn (1978).

\section{Objectieve omgeving}

Onder objectieve omgeving wordt verstaan de feitelijke situatie, onafhankelijk van de waarneming van het individu. In ons onderzoek behoren ziekenhuisgrootte, type afdelingen regio tot deze categorie. Ook role-senders en hun meningen over taken en rollen van hoofdverpleegkundigem maken deel uit van de objectieve werkomgeving.

\section{Subjectief waargenomen omgeving}

Dit is de werkomgeving zoals het individu die ervart. De variabele ervaren rolonduidelijkheid hoort in dit kader thuis.

\section{Reactie}

Hiertoe rekenen wij de psychologische, affectieve en gedragsmatige reacties die tengevolge wan ervaren rolonduidelijkheid kunnen optreden. Enkele zijn bijvoorbeeld arbeidsontevredenheid, rolconflicten en afnemen van zelfachting.

\section{Psychosomatische klachten}

In deze caltegorie gaan wij relaties na tussen ervaren rolonduidelijkheid en lichamelijke en psychische reacties daarop.

\section{Persoonskenmerken}

Hiermede worden al die variabelen bedoeld die min of meer duurzaam met de persoon zijn verbonden, zoals bekwaamheden en behoeften, flexibiliteit/rigiditeit. leeftijd, geslacht en burgerlijke staat. 


\section{Intermenselijke verhoudingen}

In dit onderzoek verstaan we hieronder de sociale relaties die hoofdwerpleegkundigen op het werk en thuis onderhouden.

\section{Verbanden}

De pijlen in het schema geven de mogelijke verbandern aan tussen de verschillende kaders. Ze hebben het karakter van hypothesen.

Hypothesen die betrekking hebben op objectieve werkomgeving en subjectief waargenomen omgeving, leggen bv. relaties tussen verwachtingen van role-senders en ervaren rolton)duidelijkheid van hoofdverpleegkundigen. Hypothesen over de relaties tussen subjectief waargenomen omgeving en reacties, veronderstellen bv. verbanden tussen ervaren rolonduidelijkheid en arbeidsontevredenheid. Hypothesen over persoonskenmerken en ervaren rol(on)duidelijkheid relateren bv. rigiditeit aan ervaren rolduidelijkheid of gaan na hoe de reacties op ervaren rolonduidelijkheid wan rigide hoofdverpleegkundigen verschilt van die van meerflexibele collega's. Hypothesen over intermenselijke verhoudingen en ervaren rolonduidelijk heid veronderstellen bv. verbanden tussen goede intermenselijke verhoudingen en ervaren rolduidelijkheid. Ook kunnen zij relaties formuleren tussen als goed ervaren intermenselijke verhoudingen en milde reacties op ervaren rolonduidelijkheid.

\subsection{Rol-theoretische achtergrond}

Een van de theorieën in de sociale wetenschappen waarmee men op systematische wijze inzicht kan verkrijgen in menselijke gedragingen, met het doeleen beschrijving, woorspelling en verklaring ervan te geven is de roltheorie.

Het uitgangspunt van deze theorie, het begrip "rol", is niet alleen een complex begrip, maar bestrijkt ook een breed terrein van het menselijk gedrag.

Visser en Van Vliert et al. (1983) omschrijven "rol" als een samenhangend geheel van verwachtingen, opvattingen, anticipaties en gedragingen die kenmerkend zijn voor een sociale relatie tussen tenminste twee individuen.

Deze omschrijving drukt uit dat "rol" iets anders is dan "taak". Daarom willen wij deze twee begrippen duidelijk uit elkaar houden. Het begrip "taak" zal straksalzon" derlijk worden behandeld en gedefinieerd.

\section{Rol}

Visser en Van Vliert noemen drie kernaspecten van het begrip "rol".

- het veronderstelt een sociale relatie tussen tenminste twee individuen;

- het veronderstelt gedrag, dat volgt uit deze sociale relatie of uit soortgelijke relaties uit het verleden;

- het veronderstelt verwachtingen t.a.v. dat gedrag.

Het rolbegrip kan in drie verschillende theoretische kaders worden geplaatst:

- sociologisch: de samenleving wordt beschouwd als een sociaal systeem, waarin de 
te vervullen rollen qua vorm en inhoud onderdeel zijn van de systemen. Het sociologisch rolbegrip is een structureel begrip.

- sociaal-psychologisch: de rol die iemand vervult wordt door hem en door rolesenders in een interactie gevormd. Het sociaal-psychologisch rolbegrip is interactionistisch van aard.

- persoonskundig: de persoon die zujn eigen wereld ontwerpt, inclusief de rollen die hij vervult, staat in het middelpunt. Dit rolbegrip is personalistisch.

De grondlegger van het structurele rolbegrip is de cultureel-antropoloog Linton (1936). Hij hield zich bezig met de vraag wat de meest fundamentele bouwstenen zijn van de maatschappij. Hij beschouwt de samenleving als een sociaal systeem, opgebouwd uit onderling samenhangende statussen of posities met wederzijdse rechten en plichten. In ons geval bijvoorbeeld: bepaalde rechten van de patiënt zijn de plichten van de verpleegkundige.

Het structurele rolbegrip heeft gevolgen voor de visie op zowel maatschappij als individu. De persoon wordt gezien als de vervuller van diverse rollen. Zijn verlangens vallen samen met de behoefte van het sociale systeem (Parsons 1951) of zijn daarmede in strijd en worden door de samenleving onderdrukt (Dahrendorf 1958).

Het interactionistische rolbegrip, waarvan Mead (1934)en Moreno(1934) grondleggers zijn, legt de nadruk op het samenspel tussen ego en alter. Begrippen als "roletaking" en "rolle-making" staan in hun theorie centraal. Volgens hen is de rol het uiteindelinke resultaat van de onderhandelingen over collectieve verlangens en individuele wensen.

Kelly (1955) plaatst het rolbegrip in een persoonlijkheidstheorie. Hij zegt dat de mens anticipeert op de interactie door het interpreteren van de ander. In Kellys eigen woorden (1955) "When one plays a role, he behaves according to what he believes another person thinks, not merely according to what the other person appears to approve ar disapprove."

Visser en Van Vliert (1983) omschrijven enkele rol-theoretische concepten als wolgt: Rolverwachting: datgene wat een indivudu volgens tenminste één ander individu in een bepaalde rolsituatie behoort te doen of te laten.

Rolopvatting: datgene wat een individu volgens zichzelf in een bepaalde rolsituatie behoort te doen of te laten.

Rolanticipatie: datgene wat een individu volgens tenminste één ander individu of volgens zichzelf in een bepaalde rolsituatie zal doen of laten.

Rolgedrag: datgene wat een individu in een bepaalde rolsituatie doet of nalaat. In deze studie worden meer roltheoretische begrippen gehanteerd. Deze worden gedefinieerd in hoofstuk 4 bij het beschrijven van de variabelen.

\section{Taak}

Het begrip "taak" wordt in de dagelijkse praktijk soms als synoniem beschouwd van "rol". Als men zegt: "De taak van de huisvrouw wordt niet gewaardeerd" dan bedoelt men dat haar rol niet in hoog aanzien staat. Bij "de rolverdeling tussen man en vrouw" is het begrip "rol" synoniem met "taak". 
Als gevolg van het onderling vervangen van deze termen is er spraakverwarring over de praktische gevolgen van "rol" en "taak". Als hoofdverpleegkundigen zeggenonvoldoende te weten wat anderen wan haar werwachten (rolonduidelijkheid) krijgen zij bijvoorbeeld niet zelden ten antwoord: "Maar je hebt tocheen taak-analyse?" (taakduidelijkheid).

Het "wat" (taak) behoeft echter geenszins samen te vallen met het "hoe" (rol). Hoofdverpleegkundigen kunnen bv. duidelijk weten dat de taak "begeleiden van de patiënt" aan haar wordt toebedeeld (taakduidelijkheid), maar on kundig zijn van de verwachtingen van anderen hoe dit in concreto in te vullen (rolonduidelijkheid).

Wat verstaan wij onder "taak"?

De literatuur over taakanalysen bevat termen als werk, positie, module, functie, taak, subtaak en element, die alle verwijzen naar werkactiviteiten; ze hebben niet alle dezelfde inhoud.

McCormick (1979) omschrijft een taak als:

- a group of related, manual, goal-directed activities that have a definite beginning and end;

- it involves interaction with equipment, other people, and/or media;

- when performed, it results in a meaningfull product.

"Taak" verwijst dus meer naar de instrumenteel-technische aspecten van de functie (het "wat") en "rol" meer naar de sociaal-dynamische dimensies daarvan (het "hoe").

\subsection{Literatuur over rolonduidelijkheid}

Hoofdstuk 2 beschrijft werkspanningen van hoofdverpleegkundigen. Wij hebben aan het begin van dit hoofdstuk besloten daaruit één enkel probleem, de rolonduidelijkheid, te selecteren en intensief te bestuderen. Dit probleem is ondergebracht in een conceptueel kader dat in deze studie als gids zal fungeren.

Vanuit zes invalshoeken zal de betekenis van de rolonduidelijkheid van hoofdverpleegkundigen worden bestudeerd.

Wat zegt de literatuur over rolonduidelijkheid vanuit deze zesdelige optiek? Wijzullen daarvan nu een korte samenvatting geven.

\section{Objectieve werkomgeving en rolonduidelijkheid}

Tot de objectieve werkomgeving rekenen wij alles wat niet tot het subject, de hoofdverpleegkundige, behoort.

\section{Type afdeling en ideologie}

Dat stress en rolonduidelijkheid bij hoofdverpleegkundigen per type afdeling kan verschillen, is de conclusie die Leatt en Schneck (1980) uit hun onderzoek trokken. $\mathrm{Zij}$ ondervroegen 153 hoofdverpleegkundigen van ardelingen met verschillende geneeskundige specialisaties. Uit hun onderzoek blijkt dat er vijf verschillende 
stressbronnen voor hoofd verpleegkundigen zijn. Deze komen woort uit de administratieve werkzaamheden, de contacten met de patiënten, de taakonduidelijkheden, de personeelsbezetting en de contacten met de specialisten. De auteurs zeggen ook dat de rol van hoofdverpleegkundigen op verschillende afdelingen anders wordt geinterpreteerd.

Tot dezelfde conclusie komt Nuyens (1968). Hij schrijft deze verschillende rolinterpretaties toe a an diverse ideologieën die in het ziekenhuis naast elkaar functioneren. Onder ideologie wordt verstakn een systeem van opvattingen dat een uitdrukkelijke rechtvaardiging van gewoonten, praktijken en gedragingen van een bepaalde groepering inhoudt. Een ideologie verwijst vooral naar centrale groepswaarden. Nuyens zegt dat door empirisch onderzoek in ziekenhuizen drie verschillende basisideologieên zijn vastgesteld: van medici, van verpleegkundigen en van thet overige afdelingspersoneel. Volgens de auteur kan in deze segregatie de verklaring liggen voor rolonduidelijkheid en voor regelmatig terugkerende interne spanningen. Hij legt verband tussen de ideologie van medici en het verschillend functioneren van verpleegkundigen op chirurgische en op interne afdelingen. Hij zegt dat chirurgische verpleegkundigen een innovatief gedrag vertonen en verpleegkundigen op interne afdelingen een ritualistisch gedrag.

Niet alleen de ideologie van medici, ook die van verpleegkundigen beïnvloedt rolpercepties. Uit een onderzoek dat Mineham (1977) verrichtte naar rolgedrag en rolduidelijkheid van verpleegkundigen, blijkt dat zij onderling zeer verdeeld zijn. De oorzaak zoekt zij in de verschillende visies die verpleegkundigen op hun beroep hebben.

Op grond van deze verschillen in opvattingen zijn "ideaaltypen" geconstrueerd (Habenstein en Christ 1955, Corwin 1960, Davis 1964 en Smith 1964). Zoschetsten Habenstein en Christ drie "ideaaltypen" verpleegkundigen: traditionalist, professionalist en practicus. Zie hoofdstuk 2.

Mineham komt in een tussentijdse rapportage van een nog niet afgerond onderzoek tot de conclusie dat rolopvattingen van verpleegkundigen in de jaren ' 70 verschillen van die uit de jaren '50. Tijdens deze veranderingen is rolonduidelijkheid ontstaan. Haasse (1976) wijst ook op factoren die de traditionele rol en functie van verpleegkundigen beînvloeden. Zij legt vooral verband tussen veranderingen van waardenen normen in de maatschappij en onzekerheden binmen de verpleging. De veranderingen in maatschappij-ideologie veroorzaken een identiteitscrisis in de verpleging. Dit is een vorm van groeps-rolonduidelijkheid die het individueel functioneren beïnvloedt.

De relatie van opleidingsideologie met rolonduidelijkheid beschrijft Kramer (1974) als de "reality-shock" in het werk: de reactie van beginners, wanneer zij na jaren opleiding tot de ontdekking komen dat theorie en praktijk niet opelkaaraansluiten. De auteur zegt dat wanneer deze discrepantie niet goed wordt opgevangen, gevoelens ontstaan als haat, angst, boosheid, zelfmedelijden en woede en dat verloop de reactie kan zijn.

Folk-Lighty en Brennen (1979) komen met onderzoeksresultaten die twijfel op- 
roepen aan de als vanzelfsprekend opgevatte relatie tussen opleidingsideologie, rolperceptie en rolonduidelijkheid. Zij ondervroegen 201 verpleegkundigen in intensive care-afdelingen van 11 aselect gekozen ziekenhuizen in Pennsylvania. Uit hun gegevens blijkt dat de rolopvattingen van verpleegkundigen meer verband houden met de dagelijkse taakvereisten dan met de opleidingsideologie. Het onderzoeksverslag vermeldt niet hoe lang geleden de opleiding werd beëindigd, dus hoe sterk de praktijk de rolduidelijkheid van verpleegkundigen kon beïnvloeden.

Freidson (1970) wijst op dit belangrijke verband. Hij zegt dat de omgeving van de ziekenhuiswerker van groter belang is voor inhoud en kwaliteit van het werk dan vroegere socialisatieprocessen.

\section{Communicatie en rolverwachtingen}

Uit een onderzoek van Hermans (1977) blijkt dat hoofdverpleegkundigen te weinig informatie ontvangen van artsen en directe superieuren. Eénderde van de afdelingshoofden krijgt onvoldoende informatie van artsen en bijna de helft hoort te weinig van directe superieuren. Uit deze studie blijkt dat er niet alleen sprake is van communicatiestoornissen tussen hoofdverpleegkundigen met artsen en directe superieuren, maar ook tussen hoofdverpleegkundigen onderling. Hermans constateert een grote variatie in rolgedrag van afdelingshoofden.

Frequente communicatie kan rolgedrag, rol(on)duidelijkheid en rolverwachtingen beïnvloeden, vooral als de role-sender een dominante positie inneemt. Hoofdverpleegkundigen blijken nogal eens in staat de opleidingsmethoden naar eigen goeddunken bij te stellen, zelfs bij hen die geacht worden de verpleegkundige praktijken uit het leslokaal in het ziekenhuis te verdedigen. Dit kan rolonduidelijkheid bevorderen bij leerlingen die hun "hoedsters" (praktijkbegeleidsters) plotseling in het andere kamp aantreffen. Zo rapporteren Rozema, Visser en Boekestijn (1980) dat zij aan een groep van 295 praktijkbegeleidsters in ziekenhuizen 29 werkaspecten voorlegden. Voor elk aspect gingen zij na hoe de rolopvattingen en rolgedrag van de respondent correspondeerden met rolverwachtingen van drie andere groepen role-senders. Eén van de resultaten van dit onderzoek is dat de praktijkbegeleidsters hun rolgedrag in ongeveer gelijke mate laten beïnvloeden door de eigen rolopvattingen en de waargenomen rolverwachtingen van hoofdverplecgk undigen. Met de waargenomen rolverwachtingen van de staf van de opleiding en van de leerlingen houden zij nauwelijks rekening.

Goede communicatie kan negatieve effecten van rolonduidelijkheid afzwakken. Dit blijkt onder meer uit een onderzoek van Posner en Randolph (1980). Zij bestudeerden de rolpercepties, rolonduidelijkheid, arbeidssatisfactie en effectief handelen wan 138 verpleegkundigen. Zij ontdekten onder anderedat verpleegk undigen, die rolonduidelijkheid ervoeren, maar in een gunstig communicatiek limaat werkten, minder arbeidsontevredenheid en minder ineffectiviteit toonden dan zij die rolonduidelijkheid ervoeren in minder open organisatiestructuren. De onderzoekers zeggen dat verbetering van organisatiestructuren een belangrijke strategie kan zijn voor het verminderen van negatieve reacties op rolonduidelijkheid.

Communicatie behoeft niet altijd het rolgedrag te beïnvloeden. Conformisme blijkt 
slechts één van de mogelijke reacties van roldragers te zijn. Sommigen houden aan hun eigen opvattingen vast, vooral wanneer zij hiërarchisch hoger staan. Een onderzoek van Benoliel (1979) wijst in die richting. Zij ondervroeg artsen en verpleegkundigen naar hun visie op het werk van verpleegkundigen. Uit antwoorden blijkt dat verpleegkundigen de meeste waarde hechten aan professionalisme (van verpleegkundigen) en het voldoen atan patiëntenverwachtingen. De artsen vonden dat verpleegkundigen zich dienen te richten op professionalisme (van verpleegkundigen) en het opvolgen van de regels van ziekenhuis en medici. De artsen gaven te kennen in de praktijk ook te handelen volgens deze verwachtingen, ondanks de afwijkende meningen van verpleegkundigen. Het hierboven aangehaalde onderzoek van Hermans (1977) bestudeert ook de rolverwachtingen wan verschillende rolesenders in relatie met de rolopvattingen van hoofdverpleegkundigen. Hij constateert discrepantie tussen rolopvattingen van afdelingshoofden en rolverwachtingen van role-senders. Vooral de verschillen tussen hoofdverpleegkundigen en medici zijn groot. Gezien de reeds eerder gemelde informatiebeperkingen en communicatiestoornissen zijn deze bevindingen begrijpelijk.

\section{Veranderingen, taakvariabiliteit en roloverbelasting}

Bij sociale interactie bestaat sterke behoefte de onzekerheid (rolonduidelijkheid) over ieders doen en laten te verminderen door per situatie bepaald gedrag van anderen en van zichzelf te verlangen. Deze rolonduidelijkheid wordt ondergraven door veranderingen, taakvariabiliteit en roloverbelasting. Zwaga (1983) wijst op de taakvariabiliteit van hoofdverpleegkundigen en de daarmede samenhangende rolonduidelijkheid. Taakvariabiliteit kan ontstaan door organisatorische veranderingen (van functieverpleging naar teamverpleging), personeelsmutaties en patiëntenmutaties. Veranderingen in patiëntenbestand, zowel concreet als in termen van wijzigingen van ziektebeeld, vereisen van hoofdverpleegkundigen herorièntatie. Zwaga wijst ook op de mogelijke relaties tussen rola mbiguiteit en roloverbelasting. Naarmate het aantal legitieme rolverwachtingen toeneemt, kunnen deze, ook al is iedere rolverwachting duidelijk overgebracht, in combinatie rolambiguiteit bewerken. De roldrager weet namelijk niet wat hij het eerste moet doen, of welke houding van hem wordt verwacht. In dit verband wijst Stolte (1976) op de moderne stijl van leiding geven die hoofdverpleegkundigen voor het dilemma plaatst van instrumenteel of expressief leiderschap.

Habeeb en McLauglin (1977) brengen rolonduidelijkheid - volgens hen het centrale probleem van verpleegkundigen - in verband met de voortdurende veranderingen in de gezondheidszorg en de onzekerheden die daaruit voor verpleegkundigen ontstaan.

De relatie tusen veranderingsprocessen en rolonduidelijkheid woor verpleegkundigen is een vaak aangehaald probleem in de ziekenhuisliteratuur(Spady 1971, Zander 1977, Gilbertson 1977, Castledine 1977). In dit verband zegt ook Koene (1980) "Onzekerheid begeleidt de verpleegkundige. Voor de patiènt is dit niet veel anders."

\section{Ziekenhuisstructuur en opkomst beroepen}

Ampe (1970) vindt dat de professioneel-bureaucratische ziekenhuisstructuur de rol- 
onduidelijkheid van verpleegkundigen bevordert. Freidson (1970) is van mening dat niet zozeer de bureaucratische structuur, maar meer de gedragingen van de professionals rolonduidelijk heid oproepen.

De snelle groei van paramedische beroepen verandert de duidelijke structuur van de ziekenafdeling. Veel verschillende groepen en evenzoveel verschillende zienswijzen en belangen maken het voor hoofdverpleegkundigen steeds moeilijker een zekere mate van rolduidelijkheid te verwerven.

\section{Subjectief waargenomen omgeving en rolduidelijkheid}

In de literatuur over stress wijzen de auteurs op de positieve kanten van stressen de uitdaging die daarvan op functionarissen kan uutgaan. Rolonduidelijkheid behoeft niet negatief te zijn en rolduidelijkheid niet altijd positief. In dit verband kunnen onderzoeksbevindingen van Redfern (1981) worden aangehaald. Zij bestudeerde werkspanningen van hoofdverpleegkundigen in Engelse ziekenhuizen. Zij vond een positieve relatie tussen rolonduidelijkheid wan hoofdverpleegkundigen en hun arbeidsontevredenheid, maar ook een positieve relatie tussen rolduidelijkheid en de intentie ander werk te zoeken. De onderzoekster vroeg hierop door. Uit de reacties bleek dat veel hoofdverpleegkundigen van mening zijn na enkele jaren de functie "in hun vingers te krijgen" (rolduidelijkheid). Hierdoor verdween de werkuitdaging; zij kregen het verlangen een andere functie te zoeken. Uit het onderzoek blijkt dat rolduidelijk heid een belangrijke voorwaarde is voor arbeidstevredenheid, maar dat, wanneer hoofdverpleegkundigen verandering van baan overwegen, rolduidelijkheid een positieve predictor blijkt te zijn voor verloop.

Sommigen vragen waarom in dezelfde structuren en omstandigheden de één wel en de ander géén rolonduidelijkheid ervaart. Persoonlijke perceptie schijnt een belangrijke interveniërende variabele te zijn. Hoe ervaren hoofdverpleegkundigen hun omgeving? Wanneer zij die waarnemen als een oppermachtig systeem, waarop hun handelen geen invloed heeft, ontstaan fricties tussen persoon en rol. Zelfvervreemding en vervreemding van de rol veroorzaken rolonduidelijkheid. Men sluit zich niet meer aan op de sent-role. Vervreemding en zelfvervreemding komen nogal eens voor in de gezondheidszorginstituten die in toenemende mate een fabrieksmatig karakter gaan dragen.

\section{Reacties op rolonduidelijkheid}

\section{Arbeids(on)tevredenheid}

Zojuist haalden wij het onderzoek aan van Redfern (1981) waaruit een relatic blijkt tussen rolonduidelijkheid en arbeidsontevredenheid.

In ons vooronderzoek bij 21 hoofdverpleegkundigen in 11 ziekenhuizen vonden wij ook een verband tussen ervaren rolonduidelijkheid en werkontevredenheid, alsmede tussen ervaren rolond uidelijkheid en bezorgd heid over het eigen functioneren. In sommige onderzoeken worden deze relaties niet gevonden (Schuler 1977, Fry en Greenveld 1980). Deze verschillen in onderzoeksbevindingen zijn misschien te herleiden tot wat Kahn (1964) noemt het verschijnsel van de zelfzenders. Dat zijn diegenen met zodanig krachtig uitgewerkte eigen rolopvattingen dat zijgeen behoef- 
te voelen de rolverwachtingen van anderen te kennen. Hierop haakt $Z$ waga (1983) in als hij de verschillen gaat verklaren:

"Wanneer de roldrager zelf geen rolopvatting heeft zal de behoefte aan rolduidelijkheid kunnen ontstaan. Indien de rolzender deze duidelijkheid niet verschaft, dan kan dit leiden tot arbeidsontevredenheid.

Wanneer de roldrager wel over rolopvattingen beschikt, dan zal afwezigheid van rolzending geen arbeidsontevredenheid tot gevolg hebben. Indien de rolzender wel rolverwachtingen overbrengt, maar hij doet dat gebrekkig, dan zal bij roldrager of hij nu wel of niet over eigen rolopvattingen beschikt, arbeidsontevredenheid ontstaan."

Behalve arbeidsontevredenheid, spreekt de literatuur over meerdere reacties op rolonduidelijkheid, zoals: het afnemen wan zelfachting, rolconflict en een zich terugtrekken uit de situatie.

\section{Afnemen van zelfaching}

De relatie tussen rolonduidelijkheid en afnemen van zelfachting wordt door verschillende auteurs beschreven.

Van Dijkhuizen (1980) vond in een studie over stress onder middenkaderleden in de industrie een relatie tussen rolonduidelijkheid en lage zelfachting en tussen onzekerheid over de toekomst in het werk (hoe ziet mijn baan er over enkele jaren uit) en lage zelfachting.

Ook Van Bastelaer en Van Beers (1982) komen in hun onderzoek naar organisatiestress bij personeelsfunctionarissen tot de bevinding dat er een relatie bestaat tussen rolonduidelijkheid en verlies aan zelfwaardering.

Cronin-Stubbs en Velsor-Friedrich (1981) beschreven ook de relaties tussen rolonduidelijkheid en geringe zelfachting. Zij denken de oorzaak van deze rolonduidelijkheid te kunnen toeschrijven aan te hoge en niet realist ische patiëntenverwachtingen. Zij ondervroegen 65 verpleegkundigen over stressfactoren en hun reacties daarop. De onderzoekers komen tot de bevinding dat rolonduidelijkheid van respondenten de op twee na belangrijkste stressfactor is. Als eerste twee noemen zij werkoverbelasting en rolconflicten. De ondervraagden zeiden dat de patiënten de rol van verpleegkundigen anders interpreteerden dan de verpleegkundigen zelf. Hierdoor voelen dezen zich schuldig niet aan de normen te kunnen beantwoorden. Daardoor werkten zij onder spanning en hun zelfachting verminderde.

In verband met andere onderzoeksgegevens, waaruit blijkt dat er ten opzichte van verpleegkundigen verschillende verwachtingspatronen bestaan, zowel vanuit patiënten als vanuit medici, zou het interessant zijn te weten vanuit welke ideologie respondenten handelden. Dit aspect werd in het onderzoek niet belicht.

\section{Rolconflict}

Kahn et al. (1964) noemen verschillende redenen waarom relaties kunnen bestaan tussen rolonduidelijkheid en rolconflict:

"The presence of conflicting role pressures may create uncertainty for the focal person. If various people press him to do different or even inconsistent things, he may not know what to do." 
Ook kunnen interzender-rolconflicten (tussen rolontvanger en -zender) en intrazender-rolconflicten (binnen de roldrager) aanleiding geven tot overbelasting en van daaruit rolonduidelijkheid veroorzaken.

\section{Zich terugtrekken uit de situatie}

Terugtrekken uit de situatie kan onder verschillende vormen plaatsvinden: lichamelijk (verloop, ziekteverzuim) of geestelijk (aparhie, medewerking weigeren of veranderingen tegenwerken). Murray (1983), die onderzoek verrichtte onder 246 gediplomeerden en leerling-verpleegkundigen, wijst op verloop onder leerlingen wanneer zij bemerken niet aan patientenverwachtingen te kunnen beantwoorden. Rolonduidelijkheid en conflicten tussen eigen rolopvattingen en verwachtingen van patiënten bleken het sterkste te leven onder de tweede-en derdejaars studenten. Daar bleek het verloop tevens het hoogst te zijn. De auteur zegt dat na diplomering de spanningen afnemen omdat de verpleegkundigen dan een groter vertrow wen in hun eigen capaciteiten krijgen.

Ook Zwaga (1983) wijst op verlooppercentages die het gevolg kunnen zijn van rolonduidelijk heid en uit het onderzoek wan Habeeb (1977) blijkt dat verpleegkundigen als reactie op rolonduidelijkheid zich terugtrek ken uit de werksituatie door werk te laten liggen.

Het tegenwerken van veranderingen is een bekend verschijnsel in de ziekenhuiswereld. Er kunnen verschillende oorzaken aan ten grondslag liggen, maar dat ongewenste rolonduidelijkheid vaak een constituerende factor vormt, wordt door veel auteurs onderschreven (Kahn 1964, Spady 1971, Zander 1977).

\section{Psychosomatische klachten en rolonduidelijkheid}

Rolonduidelijkheid kan een negatieve invloed hebben op arbeidstevredenheid, waarna vertrek kan volgen (Price 1981).

$\mathrm{Bij}$ voldoende aanbod van banen kan rolonduidelijkheid positief met verloop correleren. Als dit aanbod ontbreekt kan - volgens Zwaga (1983) - rolambiguïteit positief samenhangen met ziekteverzuim.

In de eerste literatuurstudie (hoofdstuk 2) wezen wij op een onderzoek wan Coser (1973) watruit blijkt dat verpleegkundigen in verpleegtehuizen geen zinvolle verpleegkundige doelen konden formuleren (rolonduidelijkheid), omdat zij zich identificeerden met medische doelen (het beter maken van patiënten). Deze laatste zijn in verpleegtehuizen vaak niet haalbaar. Uit gebrek aan zinvolle alternatieven was in deze in richtingen het ziekteverzuim hoog. Coser vergeleek verpleegtehuizen met revalidatieinrichtingen, waar verpleegkundigen er wél in slaagden eigen zinvolle doelstellingen te scheppen. Het ziekteverzuim lag daar aanmerkelijk lager. In Tabel 4 blijkt eveneens dat onder verpleegkundigen en verzorgenden in verpleeghuizen anno 1982 meer ziekteverzuim voorkomt dan in revalidatiecentra.

Reiche (1982), wiens onderzoek wij reeds eerder aanhaalden, vond verbandlen tussen rolonduidelijkheid en algemene gezondheidsklachten, ook tussen rolonduidelijkheid en ziekteverzuim en rolonduidelijkheid en hartk lachten.

Van Bastelaer en Van Beers (1982) vonden een verband tussen toekomstonzekerheid en gezondheidsklachten. 


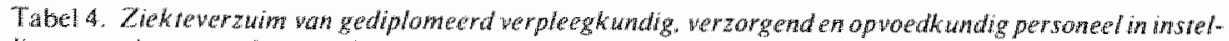
lingen wan intramurale gezondheidsorg ouer de jaren '78- $80-82$.

\begin{tabular}{|c|c|c|c|c|c|c|}
\hline \multirow[b]{2}{*}{ Instelling } & \multicolumn{3}{|c|}{$\begin{array}{l}\text { Aantal verzumdagen in ovan } \\
\text { het aanal kalenderdagen }\end{array}$} & \multicolumn{3}{|c|}{$\begin{array}{l}\text { Gemiddeld werzuim in dagen } \\
\text { per verzuim }\end{array}$} \\
\hline & 1978 & 1980 & 1982 & 1978 & 1980 & 1982 \\
\hline Alg. zickenhuraen & 6.4 & 6.6 & 6.5 & 11 & 11.3 & 10.1 \\
\hline Acad ziekenhuizen & - & 8.3 & 9.2 & - & 13 & 9.2 \\
\hline Categ. ziekenhuizen & - & 6.8 & 6.9 & - & 10.9 & 11 \\
\hline Reval centrum & 5.9 & 7.1 & 6.3 & 8.8 & 12 & 9.5 \\
\hline Psych zickenhuizen & 7.4 & 7.2 & 6,8 & 11.9 & 10,8 & 10 \\
\hline Zwakzinnigeninricht. & 6.6 & 6.3 & 6.3 & 11.4 & 10.2 & 10.2 \\
\hline Verpleegluwizen & 7.8 & 8.1 & 7.9 & 10.8 & 10.8 & 10.7 \\
\hline
\end{tabular}

Bron: Mationanl Ziekenlunsinstitunt Utrecht.

In de reeds eerder gememoreerde studie van Prins (1981) blijkt een positieve relatie aanwezig tussen rolonduidelijkheid en medicijngebruik.

Driessen (1979) onderzocht gegevens van 68 verpleegk undigen die studeerden aan de Katholieke Hogere School voor Verpleegkundigen te Nijmegen. Hij vond relaties tussen rolonduidelijkheid en gezondheidsklachten en rolonduidelijk en hartklachten.

In de literatuur worden psychosomatische klachten van werkers ook beschreven vanuit het "burn out"-verschijnsel. Onder burn out verstaat men een gevoel van psychisch en lichamelijk onvermogen om aan verwachtingen van anderen (en zichzelf) te kunnen beantwoorden (het derde stadium van het G-A-S). De werker voelt zich opgebrand. Auteurs die het burn out fenomeen bespreken leggen verbanden tussen dit psychosomatische verschijnsel en rolonduidelijkheid. Zo bijwoorbeeld de chirurg Le Maitre (1981). De rolonduidelijkheid schrijft hij toe aan tegenstrijdige opdrachten van professionals en beheerders.

Het moeten werken onder tegenstrijdige verwachtingen treft niet alleen verpleegkundigen. Wright (1982) beschrijft burn out-verschijnselen onder schoolpsychologen, die conflicterende verwachtingen ervaren.

\section{Kenmerken en persoonsgebonden variabelen van hoofdverpllegkundigen en rolondui- delijkheid}

In zijn boek."Het spel van de persioonlijkheid" worstelt Kouwer (1963) met de mens als speler van bepaalde rollen. Is hij zo, of zijn rollen maskers van schone schijn die hij, als lagen van een ui, één voor één van zich af kan pellen? Hoeverre beïnvloedt de persoonlijkheid het rolgedrag? Wat internaliseert hij; wat speelt hij?

\section{Rigiditeit en flexibiliteit}

Rolonduidelijkheid schijnt onder invloed van bepaalde persoonlijkheidskenmerken en copingstrategieën tot voor de actor aanvaardbare proporties te kunnen worden gereduceerd.

Reiche (1982) vergeleek rigide en flexibele middenkaderleden uit de industrie met 
elkaar. Een van zijn bevindingen is dat het rigide middenkaderlid een grotere rolduidelijk heid ervaart dan zijn flexibele collega. De onderzoeker zegt dat de coping van het rigide middenkaderlid erop is gericht zijn omgeving dusdanig te structureren dat hij een minimum aan rolonduidelijkheid ervaart. Tot dezelfde conclusie komt Driessen (1979). Hij onderzocht onder meer rolonduidelijk heid van verpleegkundigen in het licht wan twee karakterkenmerken: werkbetrokkenheid en rigiditeit. Hij beschouwde dogmatisme en overdreven ordelijkheid als dimensies van rigiditeit. Van hem is de volgende tabel afkomstig.

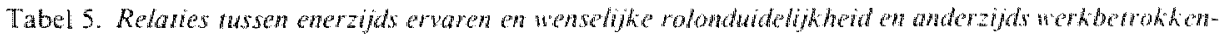
heid en rigidiveir

Werkbetrok- Dogmatisme Ordelijkheid kentheid

Rolonduidelijk heid (ervaren)

Rolonduidelijk heid (gewenst)

\begin{tabular}{rrr}
\hline$\pi$ & $r$ & $r$ \\
.02 & -.05 & -.17 \\
-.13 & -.29 & -.29
\end{tabular}

De rigide, zekerheid zoekende hoofdverpleegkundige is thet onderwerp van een studie van Baker (1979). Hij vergelijkt 50 hoofdverpleegkundigen metelkaar en gaat na hoe succesvollen en niet-succesvollen in gedragingen verschillen. Uit deze studie komt onder meer naar voren dat rolonduidelijk heid, in de vorm van veranderingen, voor niet succesvolle hoofdverpleegkundigen zeer bedreigend is. Succesvolle hoofdverpleegkundigen richten zich vooral op zelfexpressie en niet-succeswollen op zekerheid. De onderzoeker is van mening dat rigiditeit moeilijk verenigbaar is met de functie van hoofdverpleegkundigen en de daarmee verbonden rolonduidelijkheid. Fagin (1975) meent dat het zekerheid zoeken van verpleegkundigen een negatieve invloed heeft op de ontwikkelingen binnen het beroep.

\section{Mannelijke en vrouwelijke waarden}

Het geslacht van verpleegkundigen kan volgens sommige auteurs in verband staan met rolonduidelijk heid van de functionaris. Uit een onderzoek van Stromberg(1976) komt naar voren dat, naarmate de leerling-verpleegkundige zich meer mannelijk georiënteerd opstelt, zijn beeld van de verpleging meer in harmonie komt met datgene wat professionals hem ter navolging voorhouden. Mannelijke waarden zoals onafhankelijkheid, leiderschap en cerebrale prestaties zijn kwaliteiten die, volgens de onderzoekster, hoog genoteerd staan in een zich emanciperend beroep. De dissonantie en rolonduidelijk heid ontstaan als opleiders deze onathankelijke rol benadrukken bij vrouwelijke studenten die door vroegere socialisatieprocessen afhankelijke rolpatronen internaliseerden.

Masson (1981) wijst op de mannelijke en vrouwelijke waarden die liggen in de twee verschillende benaderingswijzen van de patiënt: de probleemoplossende en de koesterende. Deze tweespalt ligt, volgens haar, aan de wortel van spanningen en rolonduidelijkheid binnen de verpleging. De wetenschappelijke geneeskunde (probleemoplossend) forceert de verpleegkundigen in mannelijke benaderingswijzen. Bovendien krijgt de mannelijke, technologische aanpak vanuit de maatschappij de 
measte erkenning. Het koesterende, verzorgende, verpleegkundige element staat maatschappelijk lager genoteerd. Deze verschillende verwachtingen veroorzaken bij de verpleegkundigen rolonduidelijkheid.

De rationele, wetenschappelijke benadering kan de ontwikkeling van een empathisch invoelvermogen belemmeren. Het zich kunnen verplaatsen in de ander is echter een voorwaarde voor de "role taking". Daardoor wordt de roldrager meer geschikt een bijdrage te leveren in het interactieproces, waarin de rollen gestalte krijgen. De kille afstandelijkheid die sommigen als een muur omgeeft maakt hen onbereikbaar. De klacht "ik weet niet wat ik aan hem heb" is tevenseen signaal voor het bestaan van rolonduidelijkheid.

Bij functionarissen die een grote behoefte hebben aan bevestiging en waardering is de reactie op rolonduidelijkheid aanzienlijk negatiever dan bij hen die aan goedkeurende opmerkingen minder behoefte hebben. Kahn et al. (1964) wijzen op deze verbanden.

\section{Intermenselijke verhoudingen en rolonduidelijkheid}

Volgens Broeders (1972) valt of stat het beroep van verpleegkundige met goede intermenselijke relaties. Ook Driessen (1979) acht goede intermenselijke contacten van wezenlijk belang. Hij onderzocht de effecten van sociale ondersteuning voor verpleegkundigen. Uit dit onderzoek blijkt een relatie te bestaan tussen geringe hulpbereidheid van de chef en rolonduidelijkheid van verpleegkundigen. Ook vond hij een verband tussen geringe hulpbereidheid van collega's en rolonduidelijk heid van verpleegkundigen. Uit zijn onderzoek komt naar voren dat de hulpbereidheid van chef en collega's de spanningen ten gevolge van rolonduidelijk heid kan verminderen.

Hoekelman (1975) beschrijft de verhoudingen tussen artsen en verpleegkundigenen zegt dat de rolonduidelijkbeid tussen then door een aantal factoren kan worden verklaard. Hij wijst vooral op het fundamentele gebrek aan respect en begrip tussen de groepen. Hierdoor worden de onderlinge verhoudingen geschaad. Katz (1963), Lammers (1967) en All (1977) signaleren dat bepaalde beroepsgroepen zich van anderen afsluiten en hun eigen leefwereld met eigen normen en waarden scheppen. Zij wijzen daarbij op het ziekenhuis-kaste-systeem waar wederzijdse informatie eerder wordt geblokkeerd dan gestimuleerd. All zegt ook dat groepen met opzet onderlinge informatie beperken. Rolonduidelijkheid moet dan wel gigantische vormen alannemen.

Barness (1967) noemt de ziekenafdeling "de arena" waarbinnen velerlei en veelsoortige verwachtingen met elkaar botsen.

Goffman (1973) beschrijft de rolonduidelijkheid en roldistantie op een operatiekamer. De relaties tussen boven-en ondergeschikten zijn quasi-joviaal. Onder ogenschijnlijk democratische omgangsvormen schuilen echter dwingende etiquetten; voor beginnelingen een bron van rolonduidelijkheid.

\section{Leidinggeven}

Stolte (1976) wijst erop dat de moderne stijl van leidinggeven (volgens de human 
relations-benadering) de rolonduidelijkheid van hoofdwerpleegkundigen kan doen toenemen. Een belangrijk uitgangspunt moet namelijk volgens hem blijven: gien risico voor patiënten. Dit ve reist controlerende maatregelen van hoofdverpleegkundigen. Controleren en "modern leiderschap" kunnen echter met elkaar in conflict komen.

Hoe leiderschap, of de afwezigheid daarvan, rolonduidelijk heden kan beïnvloeden, beschrijft Doyle (1977). Een groep gezondheidszorgwerkers opende een nieuw community health center. Men wilde af wan de hiërarchische en rigide structuren die de oprichters hadden aangetroffen in overheidsziekenhuizen. In de nieuwe opzet moest gezag over alle posities worden gespreid, beslissingen door de gehele groep worden genomen. Alle stafleden, inclusief de unit-chef, de arts, de psycholoog, de maatschappelijk werkers, verpleegkundigen en hulpen, moesten beurtelings alle diensten waarnemen, óók elkaars werk. De auteur bespreekt de chaos die het gevolg was van deze werkverdeling en beschrijft de daarop volgende groei naar een meer traditionele autoriteitsstructuur. Daarin werd de rolonduidelijkheid beperkt. Hierdoor ging de staf beter functioneren en verbeterde de kwaliteit van de patiëntenzorg.

Ook sociaal-emotioneel leiderschap van hoofdverpleegkundigen kan rolambiguïteit en rolstress bij ondergeschikten verminderen.

Zwaga (1981) verrichtte onderzoek naar de effecten van leiderschapsgedrag op rolconflicten, rolambiguiteit en rolstress bij leerling-verpleegkundigen in algemene ziekenhuizen. Hij vond een bevestiging van de hypothese dat, wanneer sociaalemotioneel leiderschap méér voorkomt rolambiguïteit afneemt.

\subsection{Vraagstellingen}

Dit onderzoek houdt zich bezig met rolonduidelijk heid va n hoofdverpleegk undigen. Wij constateerden dat "taken" en "rollen" verschillende begrippen zijn. Daarom gaan wij in deze studie beide begrippen afzonderlijk behandelen. Een belangrijke vraag daarbij is of er verbanden bestaan tussen taak (on)duidelijkheid en rol(on)duidelijkheid. Een antwoord op deze vraag heeft practische consequenties. Bij aantoonbare onderlinge relaties kan men in de praktijk rolduidelijkheid proberen te bevorderen door het opstellen van taakanalysen en functiebeschrijvingen.

Indien deze verbanden echter minder duidelijk, misschien zelfs nauwelijks of niet aanwezig zijn, kan men - ter bevordering van rolduidelijkheid - niet alleen of misschien helemaal niet daarmee volstaan. Vraag 1 houdt zich met deze problematiek bezig. De in deze en volgende vragen gehanteerde termen definièren wij in hoofdstuk 4.

In vraag 2 gaan wij na hoe rolrelevante gedragsesspecten (verwachtingen, spanningen, werkbeoordelingen) door rolparen worden waargenomen. Standaard daa rbij is de hoofdverpleegkundige. Bestaan er wederzijds overeen komstige meningen?

In vraag 3 zoeken wij antwoord op een vermoeden dat gedragingen van role-senders (zoals waargenomen door hoofdverpleegkundigen) van invloed kunnen zijn op de 
rol(on)duidelijkheid van hoofdverpleegkundigen. Indien ditwordt bevestigd, willen wij tevens weten welke role-senders en welke gedragingen daartoe bijdragen (subvraagstelling hoofdstuk 6 ).

In vraag 4 gaan wij na of de institutionele context verband houdt met de ervaren rol(on)duidelijkheid wan hoofdverpleegkundigen. Vervolgens (vraag 5), wat zijn de effecten van ervaren rolonduidelijkheid op andere stressoren en strains?

In het gepresenteerde stress-model worden twee conditionerende variabelen ingevoerd, te weten persoonlijkheidskenmerken en intermenselijke verhoudingen. Deze gaan wij in de volgende vragen in verband brengen met de rol(on)duidelijkheid van hoofdverpleegkundigen. Eerst (vraag 6) gaan wij na of er verbanden aanwezig zijn tussen een bepaald persoonlijkheidskenmerk en de rol(on)duidelijkheid van het afdelingshoofd. Wij selecteerden daarvoor het persoonlijkheidskenmerk rigiditeit flexibiliteit vanwege de in de literatuur aangeduide relaties daarvan met rol(on)duidelijkheid. Vervolgens (vraag 7) vragen wij ons af of rigide hoofdverpleegkundigen heftiger of milder reageren op ervaren rolonduidelijk heid.

De drie laatste vragen betreffen de intermenselijke verhoudingen en de eventuele verbanden daarvan met de rol(on)duidelijkheid van hoofdverpleegkundigen. In vraag 8 stellen wij ons op het standpunt van de role-senders. Als zij zeggen gunstige/minder gunstige relaties te onderhouden met het afdelingshoofd, hoe zijn dan de reacties van hoofdverpleegkundigen op hun rol(on)duidelijk heid?

De twee laatste vragen baseren zich op waarnemingen van hoofdverpleegkundigen. Als hoofdverpleegkundigen gunstige/minder gunstige relaties ervaren, hoe is dan hun rol(on)duidelijkheid? (vraag 9). Als hoofdverpleegkundigen gunstige/minder gunstige intermenselijke verhoudingen waarnemen, hoe en wat zijn dan hun reacties op ervaren rol(on)duidelijkheid? (vraag 10).

1. Zijn er relaties aanwezig tussen gezamenlijke taak(on)duidelijkheid en ervaren rol(on)duidelijkheid van hoofdverpleegkundigen? (Relatie tussen blok I en 2. Hoofdstuk 5)

2. Beoordelen rolparen (hoofdwerpleegk undige is standaard) rolrelevante situaties op dezelfde wijze? (Relatie tussen biok 1 en 2 . Gezamenlijke rolond uidelijkheid. Hoofdstuk 6)

3. Bestaan er verbanden tussen ervaren rolonduidelijkheid van hoofdverpleegkundigen en het door hen als ongunstig ervaren rolrelevant gedrag van functionarissen? (Relatie tussen blok 1 en 2 . Hoofdstuk 6)

4. Bestaan er verbanden tussen de institutionele context waarbinnen hoofdverpleegkundigen-functioneren en hun ervaren rol(on)duidelijkheid? (Relatie tussen blok 1 en 2. Hoofdstuk 7)

5. Bestaan er verbanden tussen enerzijds ervaren rolonduidelijkheid van hoofdverpleegkundigen en anderzijds negatieve aspecten in de werksituatie, persoonlijke sfeer en psychosomatische klachten? (Relatie tussen blok 2,3 en 4 . Hoofdstuk 7)

6. Zijn er relaties aanwezig tussen rigiditeit van hoofdverpleegkundigen en hun ervaren rolduidelijkheid? (Relatie tussen blok 5 en 2 . Hoofdstuk 8)

7. Wat zijn de conditionerende effecten van rigiditeit/flexibiliteit van hoofdver- 
pleegkundigen op de relaties tussen ervaren rol(on)duidelijkheid an andere stressoren en strains? (Relatie tussen blok 5 en verbanden tussen blok $2,3 \mathrm{en} 4$. Hoofdstuk 8)

8. Welke conditionerende effecten hebben gunstige/minder gunstige intermenselijke verhoudingen (bezien vanuit role-senders) op de relaties tussen ervaren rol(on)duidelijkheid van hoofdverpleegkundigen en stressoren en strains? (Relatie tussen blok 1 en verbanden tussen blok 2, 3en 4. Hoofdstuk 9)

9. Is er een relatie tussen gunstige/minder gunstige sociale ondersteuning (bezien vanuit hoofdverpleegkundigen) en ervaren rol(on)duidelijkheid van hoofdverpleegkundigen? (Relatie tussen blok 6 en 2. Hoofdstuk 9)

10. Welke conditionerende effecten hebben gunstige/minder gunstige sociale ondersteuning (bezien vanuit hoofdverpleegkundigen) op de relaties tussen ervaren rol(on)duidelijkheid van hoofdverpleegkundigen en stressoren en strains? (Relatie tussen blok 6 en verbanden tussen blok 2,3 en 4 . Hoofdstuk 9)

\subsection{Samenvatting}

Uit het explorerend onderzoek, dat aan deze studie voorafging, komen twee belangrijke werkproblemen van hoofdverpleegkundigen naar voren: werkoverbelasting en rolonduidelijkheid. Daar in het onderzoek rolonduidelijkheid minder subjectief kan worden geanalyseerd dan werkoverbelasting, kiezen wij als centraal thema van deze studie: rolonduidelijkheid van hoofdverpleegkundigen.

Het begrip "rol" en "taak" hebben afzonderlike betekenissen.

McCormick (1979) omschrijft een taak als ". . . group related, goal-directed activities that have a definite beginning and end. It involves interaction with equipment, other people, and/or media. When performed, it results in a meaningful product." Visser en Van Vliert (1983) wijzen op drie kernaspecten van het rolbegrip:

- een sociale relatie tussen tenminste twee individuen;

- het begrip rol veronderstelt gedrag;

- het begrip rol veronderstelt verwachtingen.

Visser en Vliert omschrijven "rol" als een samenhangend geheel van rolverwachtingen, rolopvattingen, rolanticipaties en rolgedragingen van een individu.

Het rolbegrip kan in drie verschillende theoretische kaders worden geplatst: sociologisch, sociaal-psychologisch en persoonskundig,

Als leidraad voor het onderzoek kozen wij voor het ISR-model dat onder meer French en Caplan gebruikten in hun organisatiestudies.

De literatuurst udie over rolonduidelijkheid van hoofdverpleegk undigen verrichtten wij in het kader van bovengenoemd onderzoeksmodel.

Aan het einde van het literatuuroverzicht formuleerden wijonderzoeksvragen die de basis vormen van de onderzoeksanalysen. 



\section{Hoofdstuk 4}

\section{Opzet van het onderzoek}

De oorspronkelijke opzet van het onderzoek sloot aan bij de literatuurstudie van hoofdstuk 2. Wij wilden ons breed oriënteren en ontwierpen instrumenten met deze intentie als achtergrond. Een eerder verslag (Van den Bergh-Braam 1981) bevat een uiteenzetting van de gevolgde onderzoeksmethode.

In de voorliggende studie - waarin een klein deel van de verzamelde gegevens wordt gebruikt - beperken wij ons tot het beschrijven van de onderzoeksmethode die voor deze rapportage relevant is.

Het onderzoek verliep in drie stadia: literatuuronderzoek, vooronderzoek, hoofdonderzoek.

\section{Literatuuronderzoek}

Het literatuuronderzoek werd afgesloten met het rapport "Het rolconflict van hoofdverp》leegkundigen" Stressgroep Nijmegen. Publicatie no. 4. Intern rapport 78 AO 021978.

\section{Vooronderzoek}

De doelstelling van het onderzoek was:

- de onderzoeksopzet door middel van veldonderzoek in de ziekenhuizen te testen;

- de wraagstellingen uit te diepen;

- de onderzoeksinstrumenten aan te passen.

\section{Opzel vooranderzoek}

Wij kozen voor een zogenaamde role-setbenadering.

De role-setbenadering heeft een lange traditie. De betekenis van het sociaal referentiekader wordt reeds lang door veel onderzoekers benadrukt, zoals Le Play (1879), Malinowski (1884), Whyte (1943), Merton (1949), Bales (1953) en Parsons (1953). Ook Kahn (1964) verrichtte onderzoek waarin de groep centraal staat. Zijn model is door verschillende onderzoekers - soms in gewijzigde vorm - overgenomen. Ook verschillende studies over stress hanteren de role-setbenadering. Er is nóg een belangrijke reden om voor de role-setbenadering te kiezen. Verschillende auteurs becritiseren de onderzoeksresultaten van een survey als te individualistisch. Galtung (1970) is één van hen. Hij wijst erop dat de verk regen informatie te subjectiel is als een bepaalde functionaris geïsoleerd bestudeerd wordt en men geen navraag doet bij de hem omringende personen. 
De role-set concentreent zich op cen centrale figutur (focal person) en een aantal functionarissen uit de werk situatie met wie de centrale persoon regelmatig in contact statat. Deze functionarissen, de zogenaamde role-senders, hebben werwachtingen ten opzichte van de centrale figuur. De focal person en de role-senders vormen samen de role-set.

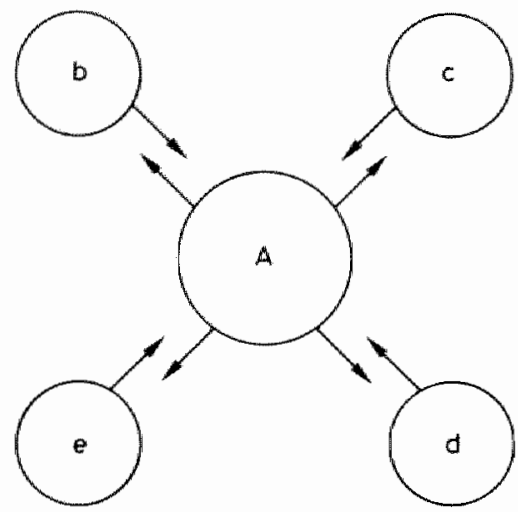
A. Hooldverplecgkundige
b. Directe superieur
c. Specialist
d. Gediplomearde
c. Loterling-verplecgkundige

Miguer 5. Schomate-set.

De directe superieur (b) heeft niet altijd eenzelfde positie. In het ene ziekenhuis is hij lid wan de directie of van een stafbureau of hoofd verplegingsdienst. In een a nder is hij coördinerend hoofdverpleegk undige of algemeen hoofdverpleegkundige (C.H.V./ A.H.V.). Om deze verscheidenheid aan te duiden is de cirkel $b$ in tweeën gedeeld.

\section{Steekproef vooronderzoek}

Aan het vooronderzoek namen II ziekenhuizen deel. Per ziekenhuis werden 2 ziekenafdelingen benaderd. In totaal konden slechts 21 role-sets in het vooronderzoek worden betrokken, ondat in één ziekenhuis een role-set uitviel. Alle role-setleden, met uitzondering van 4 specialisten, verleenden hun medewerking. In het vooronderzoek zijn ook 30 patiënten betrok ken.

\section{Merhodologische bevindingen}

De role-setbenadering bleek voor ons onderzoeksdoel geschikt. Wij besloten de reeds eerder genoemde role-setleden in het hoofdonderzoek aan te houden. Patiènten participeren echter niet meer in het hoofdonderzoek. Dit omeen drietal redenen: wit de vragenlijsten blijkt dat zij vaak de hoofdverpleegkundigen niet kennen, veel vragenlijsten werden onvolledig geretourmeerd en bovendien bleek de procedure om via ziekenhuisadministraties medewerking van patiënten te verzoeken, voor sommige instituten te tijd rovend. Wij vonden een compromis door vragenlijsten aan te passen en méér naar patiënten te informeren.

Het viel ons op dat hoofdverpleegkundigen uit kleinere ziekenhuizen soms andere spanningen rapporteerden dan hun collega"s uit grotere. Ook merkten wij verschilllen per ziekenafdeling en per regio. Daarom besloten wij in de steekproef voor het 
hoofdonderzoek drie stratificatiecriteria aan te houden: groot/klein ziekenhuis, type ziekenafdeling en regio.

\section{Hoofdonderzoek}

De opzet en verloop van het hoofdonderzoek kunnen wij als volgt indelen:

- de onderzoeksmethode;

- de waarnemingseenheden:

- het meten van de variabelen.

\section{Onderzoeksmethode}

Wij kozen voor gestructureerde interviews met hoofdverpleegk undigen, anngevuld met Vragenlijsten OrganisatieStress (VOS-lijsten). De role-senders ontvingen enquêteformulieren.

De interviews werden afgenomen door medewerkers van het Instituut voor Toegepaste Sociologie (ITS) te Nijmegen. Met het ITS werd contact onderhouden over het aanpassen van instrumenten. Het instituut verzorgde het drukken van vragenlijsten, de organisatie van het veldonderzoek, het selecteren van interviewers, hulp bij interview-training, het registreren van de respons, het uit lijsten van de vragenlijsten en het overbrengen van de gegevens op een computertape.

\section{Waarnemingseenheden}

De onderzoekspopulatie bestaat uit algemene en academische ziekenhuizen in Nederland. Wij verstaan onder algemene ziekenhuizen: alle instellingen die werkzaam zijn op het terrein van behandeling en werzorging van zieken en die met name zijn genoemd in het rapport: "Functieclassificatie van algemene ziekenhuizen in het kader van het basisonderzoek kostenstructuur" deel 3 no. 75.76, uitgegeven door het Nationaal Ziekenhuisinstituut te Utrecht.

De steekproef werd aselect uit de genoemde onderzoekspopulatie getrok ken. Daar in het NZI-rapport de lijst vanacademische ziekenhuizen on tbreekt, werd deze eraan toegevoegd.

Alle ziekenhuizen die het verzoek kregen aan het hoofdonderzock deel to nemen, hebben thierop positief gereageerd. Op het laatste moment heeftén zickenhuis zich om onbekende redenen uit het onderzoek teruggetrokken.

De steekproef werd gestratificeerd op ziekenhuisgrootte, regio en type afdeling.

Bij het zoeken naar criteria om de ziekenhuizen in te delen naar grootte is gebleken dat er veel verschillende omschrijuingen bestaan.

De functieclassificatie-criteria van het NZI bleken - hoewel niet perfect-het meest voor ons doel geschikt. Bij deze criteria werkt men met twee invalshoeken.

a. Hoeveel specialismen worden in het ziekenhuis uitgeoefend (functieclassificatic medische staf)? Een gering gedifferentieerde medische staf krijgt het getal 1 . Hoc meer specialismen hoe hoger het getal. Het hoogste cijfer is 4 . Wij gaven academische ziekenhuizen het getal 5 . 
b. Ook kan men cen functieclassificatie maken n.a.v. het aantal faciliteiten en nevenafdelingen van het zickenhuis, zoals röntgenafdeling, allerlei soorten laboratoria, e.e.g. e.c.g., eigen apotheek, intensive care, nierdialyse, mega-volt-therapie, echo-encefalografie, fonocardiografie en vectorcardiografie.

Wij kozen voor de eerste functieclassificatie-indeling.

Wij selecteerden drie regio's:

- West (Noord-en Zuid-Holland);

- Midden (Overijssel, Utrecht, Gelderland);

- Zuid (Zeeland, Noord-Brabant, Limburg).

Om ook kleine ziekenhuizen in het onderzoek te kunnen betrekken, kozen wij voor de volgende afdelingen:

- chirurgische afdeling;

- interne afdeling;

- gynaecologische/obstetrische afdeling:

- overige afdelingen.

Wij besloten uit iedere classificatie 7 ziekenhuizen aselect te trekken en uit de academische ziekenhuizen drie te benaderen. De verdeling is als volgt:

Functieclassificatie 1

Functieclassificatie 2

Functieclassificatie 3

Functieclassificatie 4

Academische ziekenhuizen

Totaal:

Hiervan per regio:

West

Midden

Zuid
7 ziekenhuizen

7 ziekenhuizen

7 ziekenhuizen

7 ziekenhuizen

3 ziekenhuizen

31 ziekenhuizen

De afdelingen, verdeeld naar ziekenhuisgrootte zijn:

Funcrieclassificanie

10 ziekenhuizen

10 ziekenhuizen

II ziekenhuizen

Totaal afdelingen

\begin{tabular}{lcccccc} 
Type afdeling & 1 & 2 & 3 & 4 & acad. & \\
\cline { 1 - 3 } Chirurgie & 7 & 7 & 7 & 7 & 3 & 31 \\
lnterne & 7 & 7 & 7 & 7 & 3 & 31 \\
Gyn./Obst. & 7 & 7 & 7 & 7 & 3 & 31 \\
Overige afd. & 7 & $\frac{7}{28}$ & $\frac{7}{28}$ & $\frac{7}{28}$ & $\frac{3}{12}$ & $\frac{31}{28}$
\end{tabular}


De steekproef is als volgt verdeeld:

Binnen de afdeling

Hoofdverpleegkundigen

Role-senders

Tussen de

afdelingen

Hooldverpleegkundigen

Role-senders

Tussen zieken-

huizen

Hooldverpleegkundigen

Role-senders
124

lotal respondenten

496

124

496

620

Chir. Int. Gyn. Overige

$\begin{array}{rrrr}31 & 31 & 31 & 31 \\ 124 & 124 & 124 & 124\end{array}$

496

620

Functieclassificatie

$\begin{array}{rrrrcr}1 & 2 & 3 & 4 & \text { acad. } & \\ 28 & 28 & 28 & 28 & 12 & 124 \\ 112 & 112 & 112 & 112 & 48 & 496 \\ & & & & & 620\end{array}$

West Zuid Midden

$\begin{array}{lll}40 & 44 & 40\end{array}$

124

$160 \quad 176 \quad 160$

Role-senders

$160-176-160$

\section{Feitelijke onderzoekspopulatie}

Door weigering van een ziekenhuis uit het westen van het land en het niet tijdig meer kumnen inschakelen van een andere instelling, zijn in groep "functieclassificatie 3" slechts 6 ziekenhuizen in plaats van 7 betrokken.

Onze onderzoekspopulatie bestaat dus uit 30 ziekenhuizen. Het mogelijke aantal respondenten is dus: 120 hoofdverpleegkundigen en 480 role-senders, teramen 600 respondenten.

\section{Criteria voor respondenten}

De volgende criteria zijn aangehouden bij de selectie van de respondenten.

De hoofdverpleegkundige moet minimaal vier maanden op de afdeling werken en dient het hoofd van een verpleegafdeling te zijn. Dus niet van een poliklinick of operatiekamer. Als de afdeling geen hoofdverpleegkundige heeft, fungeert het subhoofd als focal person.

Directe superieur is de functionaris die in de lijnorganisatie direct boven het afdelingshoofd staat. Wie dat kan zijn is beschreven bij de bespreking van de role-set. Medische specialisten moeten minimaal vier maanden werkzaam zijn op de afdelingen waar de focal person in functie is. Indien meerdere specialisten aan dit 
criterium beantwoorden, dan dient uit hen één aselect te worden gekozen.

Gediplomeerden moeten minimaal twee maanden op de afdeling werken en geen subhoofd, instructieverpleegkundige of praktijkbegeleidster zijn. Indien meerdere gediplomeerden aan dit criterium beantwoorden, dan dient uit hen éen aselect te worden gekozen.

Leerling-verpleegkundigen dienen minimaal twee maanden werkzaam te zijn op de afdeling en liefst bezig met het tweede jaar van hun opleiding. Indien zo iemand niet aanwezig is, dan voldoet ook een derdejaars leerling. Bij meerdere kandidaten dient uit hen een aselecte keuze te worden gemaakt.

\section{Respons}

Het veldwerk startte 12 mei 1980. De rappèl-fase begon op 25 juni 1980. Op 1 augustus 1980 werd het veldonderzoek definitief afgesloten. De respons was als volgt.

Alle ziekenhuizen die zich in principe bereid verklaarden aan het onderzoek te participeren, hebben - op één na-deelgenomen aan het onderzoek.

In één participerend ziekenhuis hebben alleen de vier hoofdverpleegkundigen geantwoord. De role-senders stuurden geen lijsten op, ook niet na de rappèl-fase. Toen wij hierover spraken met de contactpersonen van het ziekenthuis, bleek dat het onderzoek binnen de organisatie onvoldoende was voorbereid. De role-senders, vooral de medici, ervoeren de plotseling circulerende lijsten als en soort overval, waaraan zij geen medewerking wilden geven.

De respons van de specialisten was in het hele onderzoek het laagste. Vanwege de ervaring uit het vooronderzoek was dit voor ons geen onverwachte gebeurtenis.

De respons is:

Mondeling interview hoofdverpleegkundigen

VOS-lijsten hoofdverpleegkundigen

$(N=120) \quad 100 \%$

Directe superieuren

$(\mathrm{N}=116) \quad 97 \%$

Specialisten

$(\mathrm{N}=102) \quad 85 \%$

Gediplomeerden

$(\mathrm{N}=95) \quad 79 \%$

Leerling-verpleegkundigen

$(N=109) \quad 9.1 \%$

$(\mathrm{N}=104) \quad 87 \%$

\section{Dataverwerking}

Het Instituut voor Toegepaste Sociologie (ITS) te Nijmegen verzamelde de interviews en ingevulde vagenlijsten. Het verzorgde het overbrengen van de data opeen computertape. Voor het verwerken van de gegevens is het SPSS-programma gebruikt.

\section{Onderzockspopulatie in deze studie}

De oorspronkelijk geregistreerde 120 role-sets, met ieder vijf respondent-categorieën, blijken niet voltallig te zijn. Van 81 role-sets zijn alle vragenlijsten ingevuld ( $N$ 405). Deze studie beperkt zich daarom tot deze 81 role-sets. Lokaliseert de nonrespons zich vooral in bepaalde ziekenhuisgrootte, regio's of type afdeling? 
Deelname per regio

Geselecteerd

Gereageerd

9

West

9

9

100

Midden

10

8

80

Zuid

11

9

82

Torale deelname role-sets

Geselecteend

120

81

68

Deelname role-sets per

ziekenhuisgrootte

Geselecteerd

Gereageend

$\%$

Functieclassificatie 1

28

18

64

Functieclassificatie 2

28

23

82

Functieclassificatie 3

24

21

88

Functieclassificatie 4

28

14

50

Academische ziekenhuizen

12

5

42

Deelname role-sets per

type ziekenafdeling

Geselecteerd

Chirurgie

30
30
30
30

30

30

30

Overige

Hieruit kunnen wij het volgende concluderen.

Van de oorspronkelijke 30 deelnemende ziekenhuizen participeren in dit onderzoeksverslag $26(87 \%)$. In het westen van het land viel geen enkel ziekenhuis uit, in het midden en zuiden ieder 2 . Van de oorspronkelijk 120 role-sets bleven $81(68 \%)$ over. Van de totaal 39 wegens incomplete respons of totale weigering uitgesloten role-sets bevinden zich 21 in de grotere ziekenhuizen, te weten 14 in de groep functicclassificatie 4 (resteert $50 \%$ ) en 7 in academische ziekenhuizen (resteert $42 \%$ ). Door het uitsluiten wordt echter het type afdeling verhoudingsgewijs niet aangetast en ook de deelname per regio blijft evenwichtig. Omdat in de grotere ziekenhuizen een hogere non-respons is dan in de kleinere en middelgrote, dient thet generaliseren van de onderzoeksresultaten naar ziekenhuizen van "functieclassifica tie 4" en academische ziekenhuizen dus voorzichtig te geschieden. De betrouwbaarheid van de gegevens voor categorie 2 en 3 is goed; voor I wat minder.

\section{Het meten van de variabelen}

In hoofdstuk 3 presenteerden wij het globale stressmodel van Kahn (1964). 
Voor ons onderzoek vulden wij het begrippenkader als volgt in:

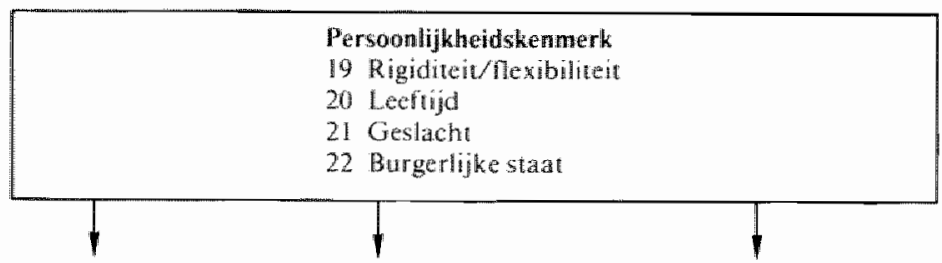

\begin{tabular}{|c|c|c|c|}
\hline $\begin{array}{l}\text { I Gezamenifike } \\
\text { taakonduidelijk- } \\
\text { heid }\end{array}$ & \multirow[t]{3}{*}{$\begin{array}{l}\text { 3. Ervaren } \\
\text { rolond uitie- } \\
\text { lifikheid }\end{array}$} & \multirow{3}{*}{$\begin{array}{l}\text { Subjectief erwaren werk- } \\
\text { situatio (stressoren) } \\
4 \text { verantwoordelijk hellid } \\
\text { woor personen } \\
5 \text { overbelasting } \\
6 \text { geen gebruik van } \\
\text { kennis } \\
7 \text { participatiegebrek } \\
8 \text { rolconflict } \\
9 \text { toekomstonzekarheid }\end{array}$} & \multirow{3}{*}{ 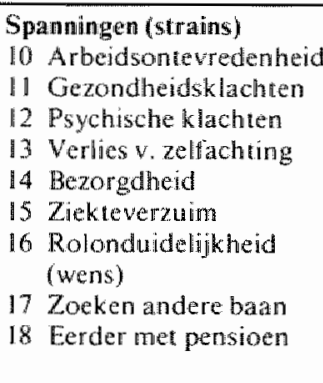 } \\
\hline $\begin{array}{l}2 \text { Gezamenlijke } \\
\text { rolonduidelijk- } \\
\text { heid }\end{array}$ & & & \\
\hline $\begin{array}{l}\text { Institutionele } \\
\text { context } \\
\text { Zickenh. groott } \\
\text { Type afdeling } \\
\text { Regio }\end{array}$ & & & \\
\hline \multirow[b]{2}{*}{. } & 4 & 4 & 1 \\
\hline & $\begin{array}{l}\text { Intermenselij } \\
23 \text { Socuale on } \\
24 \text { Soctale or } \\
25 \text { Sociale or } \\
26 \text { Sociale or }\end{array}$ & $\begin{array}{l}\text { houdingen } \\
\text { teuning chef } \\
\text { teuring collega's } \\
\text { teuning anderen } \\
\text { teuning verwanten }\end{array}$ & $\begin{array}{l}27 \text { Verstandhouding } \\
28 \text { Spanning } \\
29 \text { Verwachtingen } \\
30 \text { Werkbeordeling }\end{array}$ \\
\hline
\end{tabular}

Figutur 6. Onderzoksmodel rolonduidelijk heid hoofdverpleegk undigen.

\section{Constructie instrumenten}

De volgende vragenlijsten werden in het onderzoek gebruikt:

- de Vragenlijst OrganisatieStress (VOS-lijst);

- een vragenlijst t.b.v. het mondeling interview met hoofdverpleegkundigen;

- een vragenlijst voor role-senders.

De Vragenlijst OrganisatieStress berust op het model van French en Caplan (1972). Dit model werd geoperationaliseerd in een vragenlijst. Deze werd door De Wolff in Nederland geïntroduceerd.

Het bureau-Zuidema heeft de lijst voor Nederland vertaald. De psychometrische kwaliteiten van de VOS-lijst werden beschreven door Van Dijkhuizen en Reiche (1979) en Van Bastelaer en Van Beers (1980) en bevredigend bewonden.

Als model voor de vragenlijst voor het mondelinge interview met de hoofdverpleegkundigen dienden de vragenlijsten die gebruikt werden bij het onderzoek onder middenkaderleden (Van Dijkhuizen en Reiche 1976) en bij personeelsfunctionarissen (Van Bastelaer en Van Beers 1979). Enkele aanpassingen waren noodzakelijk. 
De wragenlijst voor role-senders werd eveneens uit het onderzoek van de middenkaderleden en personeelsfunctionarissen aangepast aan onze onderzoekspopulatie.

\section{Beschrijving van de variabelen}

$\mathrm{Nu} z u l l e n$ wij de variabelen bespreken die wij hebben gemeten. Op één uitzondering na zullen we de vragen niet letterlijk herhalen. Door middel van letters en ciffers verwijzen wij naar vragenlijst en vraagnummers $\mathrm{V}=\mathrm{VOS}$-lijst, $\mathrm{H}=$ hoofdverpleegkundigenlijst en $\mathrm{R}=$ role-senderslijst.*

\section{De centrale variabelen}

De rolonduidelijkheid van hoofdverpleegkundigen is de variabele die centraal staat in dit onderzoek. De rolonduidelijkheid wordt op twee verschillende manieren gemeten: de persoonlijke ervaren rolonduidelijkheid en de gezamenlijke rolonduidelijkheid.

Daarnaast meten wij tevens een vorm van taakonduidelijkheid. In Hoofdstuk 3 omschreven wij de begrippen "rol" en "taak". In hoofdstuk 4 zullen wij deze begrippen verder omschrijven en tevens de wijze aangeven waarop zij worden gemeten.

\section{Overige variabelen}

Behalve de centrale variabelen, selecteerden wij een aantal andere, waarvan wij vermoeden dat zij met de centrale variabelen samenhangen. Deze worden hieronder beschreven met het gemiddelde $(\mathrm{M})$, standaardafwijking $(\mathrm{Sd})$, betrouwbaarheid (Cronbach"s alpha $\mathrm{C}$ ) en range $(\mathrm{R})$.

\section{Siressoren}

Verantwoordelijkheid voor mensen: het bezitten van verantwoordelijkheid voor de toekomst van anderen, hun werkzekerheid, welzijn en veiligheid en voor het werkklimaat. ( $\mathrm{V} 7 \mathrm{t} / \mathrm{m} 10$ )

$M \quad$ Sd $\quad \mathrm{C} \quad \mathrm{R}$

$\begin{array}{llll}3.70 & .60 & .74 & 1-5\end{array}$

Werkbelasting; kwantitatieve belasting door veel werk, snel moeten werken, met weinig mogelijkheden tot rust en door complexe opdrachten. ( $V$ $11 \mathrm{t} / \mathrm{m} 22)$

Niet voldoende gebruik maken van kemnis en bekwaamheden: op school, in trainingen en uit vroegere ervaring verworven kennis en vaardigheden niet voldoende kunnen gebruiken. (V 23 $\mathrm{t} / \mathrm{m} 25$ )

Participatiegebrek: het niet voldoende (kunnen) deelnemen aan overleg met superieuren over beslissingen die op het werk en de verdeling daarvan op de respondent zélf betrekking hebben. (V 29 $\mathrm{t} / \mathrm{m} 31)$

$\begin{array}{llll}2.21 & .66 & .88 & 1-5\end{array}$

* Geinteasseerden in vagenlijsten kunnen deze opvragen bij de anteur. 
Rolconflict: het moeten uitwoeren van werkzaamheden die in strijd zijn met ander werk dat gedaan moet worden. ( $\mathrm{V} 32 \mathrm{v} / \mathrm{m} \mathrm{34}$ )

Gebrek aan support van de chef: ontbreken van sociale steun bij moeilijkheden in het werk en bereidheid tot praten en luisteren. (V $35 \mathrm{~A} / \mathrm{m} 39 \mathrm{~A}$ )

Gebrek aan support van collega's: inhoudelijk gelijk aan de vragen over de chef, maar nu betrekking hebbend op de directe collega's. (V 35B t/m 39B)

Gebrek aan support van anderen op het werk: inhoudelijk gelijk aan de vragen over de chef, maar nu betrekking hebbend op anderen op het werk. (V $36 \mathrm{C} \mathrm{t} / \mathrm{m} \mathrm{39C)}$

Gebrek aan support wan verwanten en kennissen: inhoudelijk gelijk aan de vragen over de chef, maar nu betrekking hebbend op verwanten en kennissen. (V 36E t/m 39E)

Toekomstonzekerheid: onzekerheid over de toekomst van de carrière en van de bruikbaarheid van de huidige kennis over een aantal jaren. (V 40 $\mathrm{t} / \mathrm{m}$ 43)

\section{Strains}

Ontevredenheid met het werk: het werk biedt onvoldoende mogelijkheden tot zelfontplooiing. ( V $44 \mathrm{t} / \mathrm{m} \mathrm{46)}$

Gezondheidsklachten. Algemene gezondheidsklachten en hartklachten met een (vermoedelijk) psychische oorzaak. ( $\mathrm{V} 471 \mathrm{t} / \mathrm{m} \mathrm{14}$ )

Psychische klachten met een angst-, depressieen irritatie-component. ( $\mathrm{V} 481 \mathrm{t} / \mathrm{m} \mathrm{17}$ )

Verlies van zelfwaardering: een lage waardering van eigen positie en prestaties in het werk. (V 49 $1 \mathrm{t} / \mathrm{m} 3)$

Bezorgdheid over het eigen functioneren: het zich zorgen maken niet goed te functioneren door het twijfelen aan eigen kunnen en twijfels aan het geaccepteerd worden door anderen. (V $50 \mathrm{t} / \mathrm{m} \mathrm{53)}$ Ziekteverzuim: de eigen opgave van het aantal

$\begin{array}{cccc}M & \mathrm{Sd} & \mathrm{C} & \mathrm{R} \\ 1.75 & .68 & .74 & 1-5\end{array}$

$\begin{array}{llll}2.08 & .56 & .83 & 1-4\end{array}$

$\begin{array}{llll}1.64 & .37 & .71 & 1-4\end{array}$

$\begin{array}{llll}2.12 & .54 & .74 & 1-4\end{array}$

$\begin{array}{llll}2.08 & .76 & .82 & 1-4\end{array}$

$\begin{array}{llll}2.52 & .75 & .80 & 1-5\end{array}$

M $\quad \mathrm{Sd} \quad \mathrm{C} \quad \mathrm{R}$

$\begin{array}{llll}1.45 & .76 & .57 & 1-5\end{array}$

$\begin{array}{llll}1.28 & .31 & .84 & 1-4\end{array}$

$\begin{array}{llll}1.53 & .26 & .81 & 1-4\end{array}$

$2 . \quad .62 \quad .76 \quad 1-5$

$\begin{array}{llll}2.08 & .64 & .78 & 1-5\end{array}$ 
dagen dat in de afgelopen 12 maanden wegens

Rolonduidelijkheid (wens-schaal) inhoudelijk gelijk aan de vragen over rolonduidelijkheid ( $\mathrm{V}$ I $\mathrm{t} / \mathrm{m}$ 6) mar nu gericht op hoeveel onduidelijkheid men wenst. ( $V \mid \mathbb{a} / \mathrm{m} 6$ )

Zoeken van andere baan. De wens om bij vrije keuze van functie te veranderen. $(\mathrm{H} 46)$

Eerder met pensioen. De mening niet tot de pensioenleeftijd deze functie te kunnen vervullen. (H 101)

Persoonlijkheidskenmerk of persoonsgebonden variabelen Rigiditeit/flexibiliteit. Een dogmatische levenshouding t.a.v. de rol die iemand heeft in het leven en een strak vasthouden aan dagindeling (V 54 $t / m 63$

$\begin{array}{cccc}3.32 & .77 & .82 & 1-5 \\ 41.11 & 7.8 & & 25-57\end{array}$

Leeftijd (V 86)

Geslacht (V 87)

Burgerlijke staat (V 88)

\section{Intermenselijke verhoudingen}

Verstandhouding: in welke mate heeft de hoofdverpleegkundige een goede verstandhouding met role-senders. (H 14/R 24)

$\begin{array}{cccc}\mathrm{M} & \mathrm{Sd} & \mathrm{C} & \mathrm{R} \\ 1.63 & .65 & & 1-5\end{array}$

Sparningen: in welke mate heeft de hoofdverpleegkundige spanningen met role-senders? $(\mathrm{H}$ $70 / \mathbb{R} 30$ )

$1.9 \quad .94 \quad 1-5$

Verwachtingen: in hoeverre kan de hoofdverpleegkundige aan de verwachtingen beantwoorden? ( H 71/R 32)

$2.1 \quad .74 \quad 1-5$

Werkbeoordeling: in hoeverre is de hoofdverpleegkundige op de hoogte van de werkbeoordeling door role-senders? ( $\mathrm{H}$ 95/R 37)

\section{Hypothesen}

Wij veronderstellen dat de genoemde variabelen in positieve of negatieve relatie staan met rolonduidelijkheid of met de reactie daarop. Daar het score-verloop van de variabelen belangrijk is bij de interpretatie van de positieve of negatieve verbanden, zullen wij in Tabel 6 tevens de score-richting wermelden. 


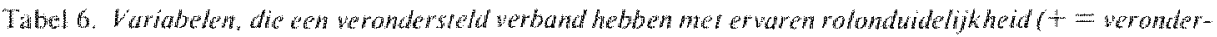

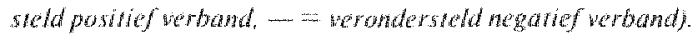

Richring een hoge waratw

Relatie met ervanen betekeni rolondudelightheid

Seressopent

1. Ervaren rolonduidelijk heid

2. Gezamenlijke rolonduidelijkheid

3. Gezamemlijke tak konduidelijkheid

4. Veranwoordilikheid

5. Werkbelasting

6. Geen gebruikmaken wan kennis

7. Participatiegobrak

8. Rolowntlict

23. Gebrek aan support wan chet

24. Gebrek aan supporl wan collega's

25. Gebrek aan supporn wan anderen op hel werk

26. Gebrek aan support wan werwanien/kennissen

9. Tockomstonzekerheid

Veel erwaren rolonduidelijk heid

veel gexamenlijke rolonduidelijk-

heid

Ved gezamentijke iakaduidelijkheid

Geen verantwoordelijkheid woor

anderern dragen

Veel werkbelasting

Geen gebruik kunnen maken wan

kennis

Geen participat in beduit vorming

Vee rolcontlicten

Gebrek aan ondersteuning door

chet

Gebrek aan ondersteuning door collega's

Gebrek aan ondersteuning door

anderen op het werk

Gebrek aan ondersteuming door

verwanten/kernissen

Veel toekomstonzeketheid

Veel arbeidsontewedenheid

Veel gezondheidsk lactuten

Veel psychische klachuen

Verlies van zelfwatardering

Bezorgdheid t.a.v. functioneren

Veel ziekteverzuim

Veel gewenstiv rolonduidelijkheid

Andere baan wensen

Liever eerder met pensioen

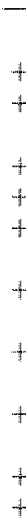

it

$+$

is

4

$+$

$+p$

$-$

$+$

it

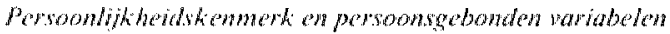

19. Rigraliveil

20. Lecellijd

Veet rigiditeil

Ouder

21. Gistofluth

22. Burgertijke statat

Man

Geen partner

Jaremenseligk werhoudingen

27. Verstindhouding

28. Spanning

29. Verwachtingen

30. Werkbeoordeling

Minder gunstige verstandhouding

Veel spanningen

Niet kunnen beantwoorden aan

verwachtingen

Onbekend met werkbeoordeling. t

$+$

i

$+$

$+$

$+$

$+$

$+$

$+$

$+$

+
+
+

Samenvatting tabel hyporhesen ervaren rolonduidelijkheid

In tabel 6 komt tol uitdrukking dat wij een negatief verband verwachten tussen ervaren rolonduidelijkheid en gezamenlijke taakduidelijkheid. Ook verwachten wij relaties tussen de als onprettig ervaren situaties in de werkomgeving en ervaren rolonduidelijkheid van hoofdverpleegkundigen. Tot deze als onprettig ervaren 
situaties in de werkomgeving rekenen wij onder andere: te veel verantwoordelijkheid woor anderen, geen gebruik kunnen maken van kennis en bek waamheden, geen participatie in de besluitvorming, rolconllicten, gebrek aan sociaal support, toekomstonzekerheid, een minder goede verstandhouding met medewerkers, onderlinge spanningen en onbekendheid met werkbeoordelingen.

Wij verwachten enkele reacties op de ervaren rolonduidelijk heid van hoofdverpleegkundigen, zoals arbeidsontevredenheid, gezondheidsklachten, klachten over psychische conditie, verlies van zelfwaardering, bezorgdheid over eigen functioneren, ziekteverzuim, een verlangen naar een andere baan en de wens om eerder dan gebruikelijk met pensioen te gaan.

Wij verwachten dat rigiditeit van hoofdverpleegkundigen een negatieve relatie heeft met ervaren rolonduidelijkheid.

Wij verwachten dat leeftijd (ouder), geslacht (man) en burgerlijke staat (geen partner) positief samenhangt met ervaren rolonduidelijk heid.

\section{Samenvatring}

Uit het vooronderzoek in 11 ziekenhuizen bleek dat de onderzoeksopzet, rolesetbenadering: interview met hoofdverpleegkundigen en vragenlijsten voor rolesenders (directe superieuren, specialisten, gediplomeerden en leerling-verpleegkundigen) in grote lijnen geschikt was voor het hoofdonderzoek. Vanwege praktische problemen besloten wij patiënten niet meer in het hoofdonderzoek op te nemen maar hen in de vragenlijsten een grotere plaats te geven.

In het hoofdonderzoek participeerden 30 ziekenhuizen.

Wij stratificeerden de steek proef op ziekenhuisgrootte, regio en type afdeling. Het aantal respondenten was 600 . Daar de oorspronkelijk geregistreerde role-sets met ieder vijf respondentcategorieèn niet voltallig bleken te zijn, baseerden wij ons in dit onderzoek naar de rol(on)duidelijkheid van hoofdverpleegk undigen op 81 role-sets (N 405).

De non-respons blijkt in grotere ziekenhuizen hoger dan in de kleine en middelgrote. Daarom dienen wij bij het generaliseren van de onderzoeksbevindingen restricties te maken voor de instituten uit "functieclassificatie 4" en academische ziekenhuizen. De selectie op grond van de non-respons heeft geen wijzigingen gebracht in de getalsverhoudingen tussen type afdeling en regio.

Het onderzoek baseert zich op een onderzoeksmodel, ontleend aan Kahn (1974) en French en Caplan (1972).

De vragenlijst organisatiestress (VOS-lijst) die als instrument in dit onderzoek fungeert, berust op het model van French en Caplan (1972).

De centrale variabele in deze studie is rolonduidelijkheid van hoofdverpleegkundigen. Deze willen wij op drie verschillende manieren meten: ervaren rolonduidelijkheid, gezamenlijke rolonduidelijkheid en gezamenlijke taakonduidelijkheid. Het definiëren en meten van deze begrippen zal geschieden in hoofdstuk 5.

Wij presenteren het reeds eerder beschreven nominale onderzoeksmodel, nu als schema in een geoperationaliseerde vorm.

Tenslotte formuleren wij de verwachte samenhang van de ervaren rolonduidelijkheid met de andere variabelen. 



\section{Hoofdstuk 5}

\section{Rolonduidelijkheid en taakonduidelijkheid van hoofd- verpleegkundigen}

In dit hoofdstuk willen wij omschrijven hoe wij de centrale variabele rollon)duidelijkheid operationaliseren en op welke wijze deze is gemeten (5.1).

Vervolgens gaan wij na in welke mate hoofdverpleegkundigen rol(on)duidelijkheid ondervinden. Ervaren hoofdverpleegkundigen méer of minder rolonduidelijkheid dan soortgelijke functionarissen in het bedrijfsleven (5.2)?

Dan wordt in 5.3 de taak(on)duidelijkheid bestudeerd vanuit verschillende gezichtspunten.

Wij besluiten dit hoofdstuk met een onderzoek naar de eventueel aanwezige verbanden tussen taak(on)duidelijkheid en rol(on)duidelijkheid (5.4) en een samenvatting (5.5).

Hoofdstuk 5 behandelt de volgende vragen:

1. Hoe worden de centrale variabelen rolonduidelijkheid omschreven en gemeten?

2. In welke mate ervaren hoofdverpleegkundigen rol(on)duidelijk heid?

3. Welke taken/contacten behoren volgens role-setleden tot de functie van hoofdverpleegkundigen?

4. Wat zijn volgens role-setleden de vijf belangrijkste taken/contacten van hoofdverpleegkundigen?

5. Taken/contactenclassificaties binnen de gehele role-set.

6. Welke dimensies onderscheiden role-setleden in de taken/contacten van hoofdverpleegkundigen?

7. Welke overeenstemming bestaat er tussen rol-paren over de vijf belangrijkste taken/contacten van hoofdverpleegkundigen?

8. Welke overeenstemming bestaat er binnen de gehele role-set over de vijf belangrijkste taken/contacten van hoofdwerpleegkundigen?

9. Bestaan er verbanden tussen gezamenlijke takk(on)duidelijkheid en ervaren rol(on)duidelijkheid?

\subsection{Omschrijving en meting centrale variabele rolonduidelijk heid}

\section{Ervaren rolonduidelijkheid}

Dit is de rolonduidelijkheid, zoals die door hoofdverpleegkundigen zélf wordt ervaren. Deze variabele komt tot stand door onderstaande 6 vragen (E-score)(VOS-lijst). Alleen voor deze variabele wordt in het onderzoek niet alleen naar de feitelijke, maar ook naar de wenselijke situatie geïnformeerd (P-score). Dit doen wij om de vraag te kunnen beantwoorden in welke mate hoofdverpleegkundigen rol(on)duidelijkheid 
wensen. Laatstgenoemde variabele zal slechts éénmaal in de analyse worden gebruikt.

$\begin{array}{lccc} & & \text { hele- } \\ \text { niet } & \begin{array}{c}\text { maal } \\ \text { zér }\end{array} \\ \text { pre- vrij } & \text { pre- enigs- } & \text { pre- } & \text { pre- } \\ \text { cies cies zins cies cies }\end{array}$

1. E. In welke mate ligt duidelijk voor u vast wát precies uw taak is?

P. In welke mate zou u willen dat dat duidelijk voor $u$ vast zou liggen?

5

2. E. In welke mate weet $u$ wat anderen op de afdeling van u verwachten?

P. In welke mate zou u dat willen weten?

$\begin{array}{lllll}5 & 4 & 3 & 2 & 1 \\ 5 & 4 & 3 & 2 & 1\end{array}$

3. E. In welke mate kunt u voorspellen welke eisen door anderen aan uw werk zullen worden gesteld?

5

P. In welke mate zou u dat van tevoren kunnen willen voorspellen?

5

4

3

2

1

4. E. In welke mate weet u wáárvoor u in uw werk wél en niét verantwoordelijk bent?

5

4

3

2

1

P. In welke mate zou u dat willen weten?

\section{5}

5. E. In welke mate weet u hoé tevreden uw directe meerdere is met wat $u$ doet?

P. In welke mate zou u dat willen weten?

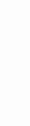

5

5

4

4

3

2

1

zeer

dik- dik- zel-

wijls wijls soms den nooit

6. E. Hoe vaak is het helemaal duidelijk wat uw taakstelling precies is? 5

P. Hoe vaak zou u wensen dat dit het geval was?

$\begin{array}{lllll}5 & 4 & 3 & 2 & 1 \\ 5 & 4 & 3 & 2 & 1\end{array}$

Het gemiddelde (M), standaardafwijking (Sd), de betrouwbaarheid (Cronbach's alpha $(C)$ en de range $(R)$ zijn: 


$\begin{array}{lcccc} & \mathrm{M} & \mathrm{Sd} & \mathrm{C} & \mathrm{R} \\ \text { Ervaren rol(on)duidelijkheid } & 2.45 & .58 & .76 & 1-5 \\ \text { Gewenste rol(on)duidelijkheid } & 1.76 & .46 & .72 & 1-5\end{array}$

\section{Gezamenlijke taakonduidelijkheid}

Wij vermoeden dat takkonduidelijkheid invloed uitoefent op ervaren rolonduidelijkheid. Daarom willen wij de taakopvattingen van hoofdverpleegkundigen in kaart brengen. Wij zullen niet alleen de taakopvattingen van hoofdverpleegkundigen zélf meten, maar ook die zoals de role-senders hen formuleren: de volgens hen vijf belangrijkste taken van hoofdverpleegkundigen.

Omdat hoofdverpleegkundigen naast velerlei soorten taken (zie $H$ 8/R 13) ook beroepshalve veel contacten dienen te onderhouden (zie H 29/R 16) informeren wij ook naar de onderlinge overeenstemming over de vijf belangrijkste contacten.

Het betreft de vragen:

1. Wat zijn de vijf belangrijkste taken van hoofdverpleegkundigen ( $\mathrm{H} 9 / \mathrm{R} 14)$ ?

2. Wat zijn de vijf belangrijkste contacten van hoofdverpleegkundigen ( $\mathrm{H} 30 / \mathrm{R} 17)$ ?

De al of niet bestaande onderlinge overeenstemming over de vijf belangrijkste taken en contacten benoemen wij met dezelfde term: gezamenlijke taak(on)duidelijkheid. De antwoorden op de vragen worden als volgt geanalyseerd: allereerst kijken wij per rolpaar of er al dan niet eenstemmigheid bestaat. Standaard is de hoofdverpleegkundige. De rolparen zijn:

hoofdverpleegkundige - directe superieur;

hoofdverpleegkundige - medisch specialist;

hoofdverpleegkundige - gediplomeerde;

hoofdverpleegkundige - leerling-verpleegkundige.

De maximum-score per paar is 5 . Dat betekent volledige overeenstemming binnen dat paar over de vijf belangrijkste taken/contacten van hoofdverpleegkundigen. De minimum-score is 0 , dan is er tussen die twee geen enkel punt van overeenstemming. Vervolgens gaan wij na of binnen de gehele role-set overeenstemming bestaat. De grootste overeen komst is $4 \times 5=20$. Totale af wezigheid van overeenkomst is $4 \times 0=0$.

\section{Gezamenlijke rolonduidelijkheid}

De klassieke sociologische en psychologische roltheorie behandelt de wisselwerking tussen de persoon en zijn sociale omgeving en culturele context. Kenmerkend voor de roltheorie is dat zij niet uitgaat van een scheiding tussen de interne en externe determinanten van het gedrag: rolgedrag wordt beïnvloed door zowel individuele als sociale factoren. De verhouding tussen het individu (hoofdverpleegkundige) en de groep (role-senders) en hun (onjduidelijkheid over rol-relevante aspecten, stat centraal bij de variabele gezamenlijke rol(on)duidelijkheid. Aan de ene kant bestuderen wij de visie en verwachtingen van role-senders ten aanzien van het rolgedrag van hoofdverpleegkundigen. Aan de andere kant is er een visie van hoofdverpleegkundigen over dezelfde aspecten die wij aan de role-senders vragen. Deze aspecten verwoorden wij in de volgende vragen: 
a. In welke mate heeft de hoofdverpleegkundige met de role-sender een goede of minder goede verstandhouding (H 14/R 24)?

b. In welke mate heeft de hoofdverpleegkundige met de role-sender spanningen ( $H$ $70 / \mathrm{R} 30)^{?}$ ?

C. In hoeverre $k$ an de hoofd verpleegkundige aan de verwachtingen van role-senders beantwoorden (H 71/R 32)?

d. Weten hooldverpleegkundigen hoe role-senders het werk van de hoofdverpleegkundige beoordelen (H 95/R 37)?

De scores op deze variabelen kunnen per item lopen van $1 \mathrm{t} / \mathrm{m} 5$. Indien de gemiddelde scores van hoofdverpleegkundige en van role-senders niet significant verschillen, spreken wij van gezamenlijke rolduidelijkheid; bij significante verschillen spreken wij van gezamenlijke rolonduidelijkheid.

5.2 Mate waarin hoofdverpleegkundigen rol(on)duidelijkheid ervaren in vergelijking met andere beroepsgroepen

Wij kunnen de gegeyens van ons onderzoek vergelijken met die van soortgelijke beroepsgroepen: middenkaderleden uit produktiebedrijven (Van Vught Tijssen e.a. 1970) en personeelchefs (Van Bastelaer en Van Beers 1979). Tevens kunnen wij vergelijkinger maken met verpleegkundigen, géén afdelingshoofden (Van Oss 1978) en met militairen (Warlicht 1977).

Tabel 7. Gemiddelden en siandarddeviaries wan ervaren en gewensterolonduidelijk heid wan hoof dverpleegkundigen en andere beroepsgroepen

\begin{tabular}{lllll} 
& \multicolumn{2}{l}{$\begin{array}{l}\text { Rolonduidelijkheid } \\
\text { (ervaren) }\end{array}$} & \multicolumn{2}{l}{$\begin{array}{l}\text { Rolonduidelijkheid } \\
\text { (gewenst) }\end{array}$} \\
& M. & sd. & Md. & sd. \\
Hoofdverpleegkundigen & 2.4 & .58 & 1.8 & .46 \\
Middenkaderleden produktiebedrijver & 2.3 & .52 & $2 .-$ & .46 \\
Personeelchefs & 2.7 & .58 & 2.2 & .46 \\
Verpleegkundigen & 2.4 & .67 & 1.7 & .42 \\
Militairen & 2.1 & .64 & $2 .-$ & .51
\end{tabular}

Uit het bovenstaande blijkt dat alle beroepsgroepen méér rolonduidelijkheid ervaren dan zij wensen. De alstand tussen ervaren rolonduidelijk heid en gewenste rolonduidelijkheid is het grootste bij verpleegkundigen (-.7), daarna bij hoofdverpleegkundigen (-.6), vervolgens bijpersoneelchefs (- .5), middenkaderleden bij produktiebedrijven ( -.5 ) en militairen (-.1).

Militairen ervaren de minste rolonduidelijkheid en personeelchefs de meeste. Verpleegkundigen en hoofdverpleegkundigen wensen de minste rolonduidelijkheid en personeelchefs de meeste.

\subsection{Taken en contacten van hoofdverpleegkundigen}

De taak(on)duidelijk heid van hoofdverpleegkundigen gaan wij nu van verschillende kanten belichten. De aan het begin van dit hoofdstuk genoemde vragen $3 \mathrm{t} / \mathrm{m} 9$ pro- 
beren alle een bepaald aspect van de taak(on)duidelijkheid te belichten. De laatste vraag: "Bestaan er verbanden tussen gezamenlijke taak (on)duidelijkheid en ervaren rol(on)duidelijkheid" is de kernvraag van dit hoofdstuk en tevens een van de belangrijkste punten van dit onderzoek. Wij vermoeden namelijk dat gezamenlijke taakduidelijkheid een basis legt voor ervaren rolduidelijkheid van hoofdverpleegkundigen.

De functie van hoofdverpleegkundigen bestaat niet alleen uit het volbrengen van taken - zoals coördinatie, verdelen en controle van het werk op de afdeling - maar ook uit een aantal contacten, bijvoorbeeld met röntgen, apotheek, keuken en personeelsadministratie. Uit de literatuurstudie weten wij dat de groeiende au tonomie van deze diensten een bron van spanningen en rollonduidelijkheid van hoofdverpleegkundigen kan zijn. Wanneer het onderzoek zich alleen tot de taken (en de daarmede samenhangende spanningen) zou beperken, blijft een gedeelte van het functioneren van hoofdverpleegkundigen onbelicht. Voor het werkrijgen van een waarheidsgetrouw beeld moeten de contacten mee in beschouwing worden genomen. Om deze reden ontwierpen wij-behalve een takenlijst - tevens een contactenlijst. Als wijin deze studie spreken over taak(on)duidelijkheid, dan is de (on)duidelijkheid over de contacten daarbij inbegrepen.

Wij stelden aan de role-setleden de vraag: "Welke taken en welke contacten behoren volgens U tot de functie van hoofdverpleegkundigen?" en legden daarbij een uitgewerkt taken en contactenschema voor.

Tabell 8. Taken die volgens role-setle den behoren tot de fumete van hoofdverpleegk undigen (in procenten).

Hoofd- Supe- Specia- Gedipl. Leerl.

1. Coördinatie werk verplk. rieur

2. Personeelsbezetting

3. Rapportage

4. Personeelsbelleid

5. Beheer medicijnem

6. Begeleiding leerlingen

7. Begeleiding co-assistenten

8. Contacten opleiding

9. Lessen opleiding

10. Verpleegkundige ontwikkelingen

11. Begeleiden artsenbezoek

12. Behandelingsplan

$\begin{array}{rrrrr}100 & 99 & 93 & 99 & 99 \\ 94 & 83 & 85 & 89 & 83 \\ 94 & 96 & 94 & 91 & 89 \\ 98 & 89 & 94 & 96 & 96 \\ 95 & 96 & 95 & 80 & 72 \\ 84 & 84 & 95 & 65 & 60 \\ 25 & 18 & 15 & 15 & 10 \\ 85 & 70 & 80 & 75 & 60 \\ 20 & 22 & 30 & 21 & 15 \\ 95 & 81 & 79 & 69 & 65 \\ 94 & 96 & 96 & 96 & 97 \\ 96 & 95 & 94 & 94 & 86 \\ 100 & 95 & 99 & 93 & 74 \\ 99 & 94 & 88 & 84 & 89 \\ 100 & 98 & 99 & 91 & 84 \\ 97 & 96 & 96 & 95 & 90 \\ 100 & 98 & 96 & 93 & 90 \\ 99 & 95 & 92 & 96 & 91 \\ 100 & 98 & 95 & 99 & 95 \\ 58 & 64 & 47 & 38 & 35\end{array}$




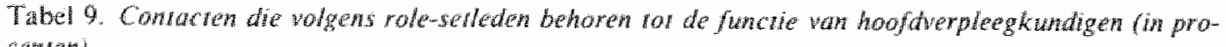
centeny.
1. Operatiekumer
2. Röntgenafueling
3. Laboratorium
4. Andere afdelingen
5. Fysiotherapie
6. Arbeidstherapie
7. Keuken
8. Huishoudelijke diens!
9. Maatschappelijk werk
10. Pasior
11. Personedscaken
12. Technische dienst
13. Administratie
14. Specialisten
15. Huisartsen
16. Directie
17. Magazijn
1\%. Gasturouwen
19. Opleiding
20. Psycholoog
21. Dictiste
22. Ondernemingsrad
23. Apotherk
24. Wijkverpleging
25. Ziekenhurishygiëniste
26. C.H.V.A.H.V.

$\begin{array}{rcccc}\begin{array}{r}\text { Hoofd- } \\ \text { verplk. }\end{array} & \begin{array}{c}\text { Supe- } \\ \text { rieur }\end{array} & \begin{array}{c}\text { Specia- } \\ \text { list }\end{array} & \text { Gedipl. } & \text { Leerl. } \\ 77 & 75 & 76 & 74 & 70 \\ 94 & 99 & 91 & 89 & 79 \\ 100 & 99 & 96 & 94 & 91 \\ 79 & 75 & 63 & 68 & 65 \\ 93 & 88 & 91 & 84 & 86 \\ 41 & 30 & 36 & 32 & 21 \\ 82 & 91 & 85 & 73 & 67 \\ 85 & 82 & 76 & 73 & 59 \\ 80 & 91 & 91 & 86 & 83 \\ 89 & 84 & 88 & 72 & 65 \\ 57 & 63 & 68 & 56 & 65 \\ 94 & 89 & 76 & 84 & 73 \\ 79 & 80 & 70 & 69 & 78 \\ 100 & 99 & 99 & 99 & 99 \\ 63 & 68 & 53 & 53 & 51 \\ 70 & 70 & 82 & 83 & 80 \\ 91 & 91 & 72 & 70 & 54 \\ 43 & 20 & 37 & 32 & 20 \\ 79 & 82 & 75 & 70 & 60 \\ 22 & 24 & 22 & 24 & 25 \\ 85 & 84 & 89 & 88 & 77 \\ 25 & 27 & 43 & 24 & 30 \\ 100 & 95 & 89 & 93 & 78 \\ 84 & 80 & 70 & 84 & 73 \\ 61 & 70 & 54 & 59 & 46 \\ 75 & 86 & 33 & 53 & 41\end{array}$

Op collectief niveau is er een opvallende eensgezindheid onder de role-setleden over de taken die behoren tot de functie van hoofdverpleegkundigen. Vele taken worden door meer dan 80 procent van de respondenten aangekruist. Coördinatie van werkzaamheden is één van de meest genoemde taken, begeleiden van co-assistenten de minst genoemde.

Wij berekenden hoeveel taken verschillende groepen gemiddeld aankruisen als behorend tot de functie van hoofdverpleegkundigen. Hieruit blijkt dat hoofdverpleegkundigen de breedste taakopvatting hebben (gemiddeld 18 taken). Daarna volgen directe superieuren en specia listen (iedere groep kruist 17 taken aan). Daarna komen gediplomeerden met een gemiddelde van 16 taken en leerlingen met een gemiddelde van 15.

Wat de contacten betreft: hoofdverpleegkundigen zeggen unaniem dat de contacten met laboratorium, specialisten en apotheek tot hun functiepakket behoren. Rolesenders beamen dit, alhoewel niet in dezelfde mate. Wij zien dat de directe superieuren hun contact met de hoofdverpleegkundigen overschatten (26. C.H.V./ A.H.V.) en dat specialisten het contact onderschatten.

Bij het berekenen van de gemiddelde aankruisings-score per beroepscategorie zien we dat hoofdverpleegkundigen en hun directe superieuren de breedste contactopvatting hebben (gemiddeld 20 contacten). Daarna volgen specialisten en gediplo- 
meerden (iedere groep kruist 18 contacten aan). Als laatste komen leerlingen met een gemiddelde van 16 contacten.

Wij zien dat hoofdverpleegkundigen hun contacten met maatschappelijk werkers minder frequent noemen dan de role-senders.

Uit gegevens van bovenstaande tabellen kunnen we voorzichtig concluderen dater vooralsnog geen aanwijzingen bestaan on van taakondudelijkheid tussen hoofdverpleegkundigen en hun medewerkers te spreken.

Kan de taakonduidelijkheid zich misschien manifesteren in de prioriteitenstelling? Wat zeggen rolle-setleden over de vijf belangrijkste taken/contacten van hoofdverpleegkundigen?

\section{De viff belangrijkste taken en contacten van hoofdverpleegkundigen}

Wij vroegen aan de gehele role-set: "Kunt U aangeven welke vijf taken (contacten) voor de hoofdwerpleegkundige het meest belangrijk zijn?" De belangrijkste taak en het belangrijkste contact kregen score 1 , de minst belangrijke de laagste score ( 20 bij de taken, 26 bij de contacten).

Vit de antwoorden blijkt dat er onderling een betrekkelijkeeensgezindheid is over de vraag welke taken/contacten van hoofdverpleegkundigen tot de vijf belangrijkste behoren. Wij dienen echter wel te beseffen dat in onderstaande tabellen groepsmeningen worden weergegeven en geen individuele meningen.

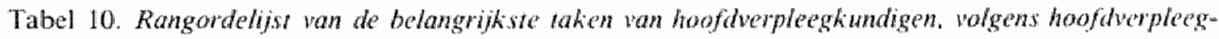
kundigen en volgens role-senders.

$\begin{array}{ll}\text { Rangorde } \\ \text { volgens } \\ \text { hoofdy. } & \begin{array}{l}\text { role- } \\ \text { senders }\end{array} \\ 1 & 1 \\ 2 & 2 \\ 3 & 3 \\ 4 & 6 \\ 5 & 7 \\ 6 & 5 \\ 7 & 8 \\ 8 & 4 \\ 9 & 11 \\ 10 & 9 \\ 11 & 10 \\ 12 & 15 \\ 13 & 12 \\ 14 & 13 \\ 15 & 14 \\ 16 & 16 \\ 17 & 20 \\ 18 & 17 \\ 19 & 19 \\ 20 & 18\end{array}$

Coördinatie werk

Begeleiden patient

Prettige werksfeer handhawen

Observeren patiënt

Personeelsbezetting bewaken

Begeleiden artsenberock

Personeelsbeléd

Behandelingsplan witvoeren

Begeleiden leerlingen

Rapportage

Begeteiden famille van de patiërnt

Opname/ontslag patient

Verpleegkundige on wwiklkelingen shimuleren

Beheer medicijnen

Regets handhaven

Deelnemen aan wergaderingen

Lessen opleiding verzorgen

Contacten opleiding

Begeleiden co-assistenten

Spreekuur bezockers

\begin{tabular}{ll}
\multicolumn{2}{l}{ Gemiddelden } \\
van & van \\
hoofdy, & role- \\
& senders \\
$1 .-$ & 1.2 \\
2.1 & 3.2 \\
3.1 & 3.5 \\
3.8 & 5.5 \\
4.2 & 6.2 \\
5.3 & 4.8 \\
6.6 & 8.8 \\
6.7 & $4 .-$ \\
8.9 & 11.7 \\
10.1 & 10.5 \\
10.4 & 10.6 \\
12.1 & $14 .-$ \\
12.2 & $12 .-$ \\
13.8 & 13.2 \\
14.1 & 13.2 \\
$15 . \|$ & $14 .-$ \\
17.2 & 19.5 \\
17.3 & $17 .-$ \\
19.1 & $19 .-$ \\
19.2 & 18.2
\end{tabular}

Uit bovenstaande gegevens blijkt dat er eenstemmigheid bestaat over de drie belangrijkste taken. Ook is men het onderling eens over de voor hoofdverpleeg- 
kundigen betrekkelijk onbelangrijke taak van het begeleiden van co-assistenten. Ook de overige taakprioriteiten wijken niet ver uit elkaar. Wij zien wel hier en daar kleine nuance-verschillen, bijwoorbeeld bij het ten uitvoer (laten) brengen van het behandelingsplan. Hoofdverpleegkundigen schatten die als de op zeven na belangrijkste taak, de role-senders beschouwen die taak als op drie na de belangrijkste.

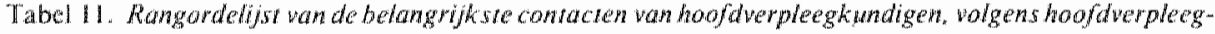
kwndigen en wolgens role-senders.

\section{Rangorde}

volgens volgens

hoofdy. roles-

\begin{tabular}{|c|c|c|}
\hline & senders & Contacter me: \\
\hline 1 & 1 & Specialistion \\
\hline 2 & 2 & Laboratoritom \\
\hline 3 & 4 & Oparaliekaner \\
\hline 4 & 5 & Rọntgen \\
\hline 5 & 6 & fysiotherapie \\
\hline 6 & 3 & Matachappelijk work \\
\hline 7 & 7 & C.H.V.JA.H.V. \\
\hline 8 & 12 & Diëtiste \\
\hline 9 & 10 & Opleiding \\
\hline 10 & 15 & Personeelszaken \\
\hline 11 & 9 & Wijkverpleging \\
\hline 12 & 19 & Keuken \\
\hline 13 & 16 & Apotheek \\
\hline 14 & 14 & Pastor \\
\hline 15 & 8 & Directie: \\
\hline 16 & 20 & Hüshoudellijke dienst \\
\hline 17 & 18 & Hubsatesen \\
\hline 18 & 23 & Technische dicnst \\
\hline 19 & 24 & Arbeidstheraple \\
\hline 20 & 13 & Administratie \\
\hline 21 & 17 & Ziekenhuishygiēniste \\
\hline 22 & 11 & Andere aldelingen \\
\hline 23 & 25 & Gastviouwen \\
\hline 24 & 26 & Mrggazijn \\
\hline 25 & 21 & Psycholoog \\
\hline 26 & 22 & Ondernemingsraad \\
\hline
\end{tabular}

\begin{tabular}{|c|c|}
\hline \multicolumn{2}{|c|}{ Gemiddelden } \\
\hline valn & van \\
\hline hoofdr. & $\begin{array}{l}\text { nole- } \\
\text { sernders }\end{array}$ \\
\hline $1 \ldots$ & 1 \\
\hline $2 n$ & 32 \\
\hline 3.2 & 3.5 \\
\hline 3.5 & 5.5 \\
\hline 4.2 & 5.8 \\
\hline $6=$ & 3.3 \\
\hline 6.2 & 6.5 \\
\hline 8 - & 11.8 \\
\hline 8.2 & 7.5 \\
\hline 10.2 & 12.8 \\
\hline 10.5 & 7. \\
\hline 11.6 & 14. \\
\hline 11.8 & 12.9 \\
\hline 12.6 & 12. \\
\hline 13.3 & 6.8 \\
\hline 14.2 & 15.5 \\
\hline 15.1 & 13.5 \\
\hline 15.5 & 17.1 \\
\hline 16.2 & 17.5 \\
\hline 16.3 & 11.9 \\
\hline $17 .-$ & $\llbracket 2.9$ \\
\hline 17.1 & 9.2 \\
\hline 17.4 & $18 .-\ldots$ \\
\hline 17.6 & 18.1 \\
\hline 17.8 & 16.5 \\
\hline 18. سمس 18 & $17 .-$ \\
\hline
\end{tabular}

Uit deze tabel blijkt dat over de contacten de meningen minder eensluidend zijn dan bij de taken. Hoofdverpleegk undigen en role-senders zijn het onderling eens over de twee belangrijkste contacten, die met de specialisten en het laboratorium. Ook is men het onderling eens over het belang van het contact met de directe superieuren ( $7 \mathrm{e}$ plaats) en met de pastor (14e plaats). Het grote verschil treffen wiji aan bij de contacten met de andere afdelingen (22e resp. 1 le plaats).

Bij het lezen van bovenstaande tabellen dient men er rekening mede te houden dat de meningen van de vier groepen role-senders bij elkaar zijn gevoegd. Hierdoor worden de verschillen tussen de groepen onderling genivelleerd.

Globaal valt er over die verschillen tussen elk van de groepen role-senders en de groep hoofdverpleegkundigen het volgende op te merken.

Terwijl alle groepen het coördineren van de werkzaamheden als de belangrijkste taak 
van hoofdverpleegkundigen beschouwen, vinden alleen hoofdverpleegkundigen en hun superieuren dat ook het handhaven van een goede personeelsbezetting tot de vijf belangrijkste taken behoren; specialisten, gediplomeerden en leerlingen rekenen die taak daar niet toe. Het begeleiden wan het artsenbezoek daarentegen noemen specialisten en leerlingen wel bij de vijf belangrijkste taken; de overige groepen doen dat niet. Het uitleggen en laten uitvoeren van het behandelingsplan is volgens hoofdverpleegkundigen zelf niet een van de vijf belangrijkste, maar de overige groepen vinden die taak wél behoren tot de top-vijf. Directe superieuren en leerlingen rekenen het observeren van de patiënt niet tot de vijf belangrijkste taken, in tegenstelling tot de andere groepen.

Het contact met de specialisten wordt door alle groepen als het belangrijkste contact van hoofdverpleegkundigen beschouwd, het contact met het laboratorium vinden ook alle groepen heel belangrijk. Hoofdverpleegkundigen directe superieuren en specialisten noemen contacten met de röntgenafdeling bij de vijf belangrijkste van het afdelingshoofd; gediplomeerden en leerlingen vinden dat contact niet zo belangrijk. Zij rekenen - net als hoofdverpleegkundigen zelf - well de contacten met de fysiotherapie tot de vijf belangrijkste.

Enkele gegevens stemmen tot nadenken. Zo blijken hoofdverpleegkundigen hun contacten met de directe superieuren niet bij de vijf belangrijkste te noemen, terwijl directe superieuren zelf dit wel doen. Gediplomeerden en leerlingen vinden de contacten tussen hoofdverpleegkundigen en maatschappelijk werk het op én na belangrijkste contact, specialisten rekenen dit contact tot de vijf belangrijkste, maar de hoofdverpleegkundigen en de directe superieuren geven dit contact nietzo'n hoge prioriteit.

Daarentegen blijken hoofdverpleegkundigen veel waarde te hechten aan het contact met diëtisten. Dit contact staat bij hen op de zevende plaats in de rangorde-lijst, directe superieuren, specialisten, gediplomeerden en leerlingen scoren dit contact respectievelijk op de dertiende, twaalfde (specialisten en gediplomeerden) en tiende plaats.

De pastor neemt bij alle groepen een middenpositie in. Wat de contacten met de directie betreft wisselen de meningen sterk. Specialisten en leerlingen noemen het contact tussen hoofdverpleegkundigen en directie één van de vijf belangrijkste, de overige groepen delen deze mening niet. Bij hoofdverpleegkundigen komt dit contact pas op de tiende pllaats, evenals bij de directe superieuren. De gediplomeerden situeren dit contact op de achtste plaats.

De contacten met de wijkverpleging nemen bij de hooldverpleegkundigen niet zo'n vooraanstaande positie in als gediplomeerden verwachten. Deze laatsten rekenen het contact hoofdverpleegkundigen-wijkverpleegkundigen tot een van de vijf belangrijkste, maar bij hoofdverpleegkundigen staat dit contact pas op de negende plaats.

Taken/contacten-classificaties binnen de gehele role-set

Doordat wij ons hebben verdiept in de vraag hoe role-setleden het taken/contactenpakket van hoofdverpleegkundigen zien en welke taken/contacten 
de role-setleden als de vijf belangrijkste beschouwen, verkregen wij twee soorten gegevens: over de taaksamenstelling en over de prioriteitenstelling.

Nu gaan wij ons afwragen of de taken/contacten die het meest frequent worden genoemd als behorend tot de functie wan hoofdverpleegkundigen, óók - vaker dan andere - voorkomen in de vijf-prioriteitenlijst. Dat zullen dan waarschijnlijk taken/contacten zijn die meer nadruk krijgen dan de andere. Leggen hoofdverpleegkundigen en role-senders dezelfde accenten?

Het is mogelijk de taken/contacten te classificeren in een aantal categorieën, die beginnen bij niet dagelijks voorkomende taken/contacten die zelden worden aangewezen als een van de vijf belangrijkste en lopen tot dagelijks voorkomende taken/contacten die zeer vaak worden aangewezen als één van de vijf belangrijkste. Deze indeling kunnen wij toepassen op de gegevens van de afzonderlijke rolesetgroepen. Door de classificatie onderling te vergelijken, kunnen wij nagaan of tussen hoofdverpleegkundigen en role-setgroepen taakduidelijkheid of -onduidelijkheid zal bestaan. Wij hanteren vijf classificatie-criteria:

1. Niet dagelijks voorkomende taken/contacten zelden aangewezen als één van de vijf belangrijkste

Hiertoe rekenen wij die taken/contacten die $50 \%$ of minder van de role-setleden aangeven als behorend tot de dagelijkse taken/contacten van hoofdverpleegkundigen. Als criterium voor zelden aangewezen geldt dat $6 \%$ of minder van de role-setleden de betreffende taak/contact tot één van de vijf belangrijkste rekent.

2. Dagelijks voorkomende taken/contacten, zelden aangewezen als één van de wijf belangrijkste

Meer dan $50 \%$ van de role-setleden noemt de taak/contact als behorend tot de functie van hoofdverpleegkundigen.

Zelden aangewezen: $6 \%$ of minder van de role-setleden acht die taak/contact tot één van de vijf belangrijkste.

3. Dagelijks voorkomende taken/contacten, soms aangewezen als één van de vijf belangrijkste

Meer dan 50\% rekent die taak/contact tot de functie van hoolidverpleegkundigen. Soms aangewezen: meer dan $6 \%$ en minder dan $12 \%$ rekent taak/contact tot de vijf belangrijkste.

4. Dagelijks roorkomende taken/contacten, vaak aangewezen als één van de vijf belangrijkste

Meer dan $50 \%$ rekent de taak/het contact tot de functie van hoofdverpleegkundigen. Vaak aangewezen: meer dan $12 \%$ en minder dan $40 \%$ rekent taak/contact tot de vijf belangrijkste.

5. Dagelijks voorkomende taken/contacten, zeer vaak aangewezen als één van de vijf belangrijkste

Meer dan $50 \%$ rekent de taak/het contact tot de functie van hoofdverpleegkundigen. Zeer vaak aangewezen: $40 \%$ of meer rekent taak/contact tot de vijf belangrijkste. 
TAKEN

Hoofdverpleeg- Superieuren Specialisten Gediplomeerdien Leerlingen digen

1. Niet dagelijks voorkomend, zelden aangewezen tot de eerste 5 taken.

$\begin{array}{lllll}\text { Begeleiden co- } & \text { Begeleiden co- } & \text { Begeleiden co- } & \text { Begeleiden co- } & \text { Begeleiden co- } \\ \text { assistenten } & \text { assistenten } & \text { assistenten } & \text { assistenten } & \text { assistenten } \\ \text { Lessen opleiding } & \text { Lessen opleiding } & \text { Lessen opleiding } & \text { Lessen opleiding } & \text { Lessen opleiding } \\ & & \text { Spreekuur } & \text { Spreekuur } & \text { Spreekubr } \\ & & \text { bezoekers } & \text { bezockers } & \text { bezockers }\end{array}$

2. Dagelijks voorkomend, zelden aangewezen tot de eerste 5 taken

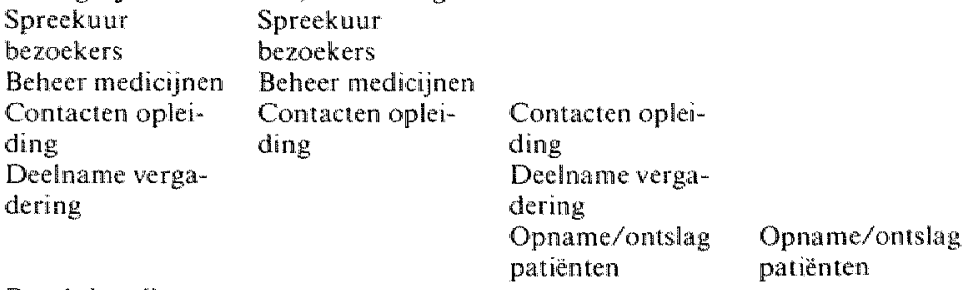

Regels handhaven

3. Dagelijks woorkomend, soms aangewezen tot de eerste 5 taken

Beheer medicijnen Beheer medicinn

Regels handhaven Regels handhaven

Contacten oplei- Contacten oplej-

ding ding

Deelname vergat-

dering

Verplgk. ontwikk.

Verplgk. ontwikk. Verplgk. ontwikk. Verplgk. ontwik.

Begeleiden fam. pat. Begeleiden leerl.

4. Dagelijks voorkomend, waak aangewezen tot de eerste 5 taken

\begin{tabular}{|c|c|c|c|c|}
\hline Rapportage & Rapportage & Rapportage & Rapportage & Rapportage \\
\hline \multirow{2}{*}{ Personeelsbeleid } & Personeelsbeleid & Personeelsbeleid & Personeelsbeleid & Personedsbeleid \\
\hline & Personeelsbezetting & Personeelsbezetting & Personeelsbezetting & Personedsberet. \\
\hline Begeleiden leerl. & Begeleiden leerl. & Begeleiden leerl. & & Begeleiden leert. \\
\hline $\begin{array}{l}\text { Begeleiden artsen- } \\
\text { bezoek }\end{array}$ & $\begin{array}{l}\text { Begeleiden artsen- } \\
\text { bezoek }\end{array}$ & & & \\
\hline $\begin{array}{l}\text { Begeleiden fam. } \\
\text { patienten }\end{array}$ & $\begin{array}{l}\text { Begeleiden fam. } \\
\text { patienten }\end{array}$ & & $\begin{array}{l}\text { Begeleiden fatul. } \\
\text { patienten }\end{array}$ & $\begin{array}{l}\text { Begeleiden fam. } \\
\text { patienten }\end{array}$ \\
\hline $\begin{array}{l}\text { Opname/ontslag } \\
\text { patienten }\end{array}$ & $\begin{array}{l}\text { Opname/ontslag } \\
\text { patiénten }\end{array}$ & & & $\begin{array}{l}\text { Opname/ontslag } \\
\text { pationten }\end{array}$ \\
\hline & Observeren pat. & & & Obserweren pat. \\
\hline Behandelingsplan & Verplgk. ontwikk. & Beheer medicujnen & & \\
\hline & $\begin{array}{l}\text { Deelname verga- } \\
\text { dering }\end{array}$ & & & $\begin{array}{l}\text { Dechame verga- } \\
\text { dering }\end{array}$ \\
\hline & Regels handhaven & & & Regels handlr. \\
\hline
\end{tabular}

5. Dagelijks voorkomend, zeer yaak aangewezen tot de eerste 5 taken

Coördinatie werk Coördinatie werk Coördinatie werk Coördinatie werk

Prettige werksfer Prettige werksfeer Prettige werksfeer Prettige werksfeer

Begeleiden patient Begeleiden patiënt Begeleiden patiënt Begeleiden patiënt

Coördinatic werk

Prettige werksi".

Begeleiden pat.

Olaserveren patiënt

Behandelingsplan Behandelingsplan

Behandelimgspl.

Personeelsbezetting

Observeren patiènt

Begeleiden

Observeren patiéni

artsenbezoek

Begeleiden

Begeleiden

antserbezoek 
Hoofdverpleeg- Superieuren Specialisten Gediplomeerden Leerlingen kundigen

1. Niet dagellijks voorkomend, zelden aangewezen tot de eerste 5 contacten

Ondermemingsraad Ondememingsraad Ondernemingstaad Ondernemingsraad Ondern. raad Arbeidstherapie Arbeidstherapie Arbeidstherapie Arbeidstherapie

Gastyrouwen Gastwrouwen Gasturouwen Gasturouxyen Arbeidstherapic

Psycholoog

Psycholoog

Psycholoog

Psycholoog

Gastwrouwen

Psycholoog

2. Dagelijks voorkomend, zelden aangewezen tot de eerste 5 contacten

\begin{tabular}{|c|c|c|c|c|}
\hline $\begin{array}{l}\text { Magazijn } \\
\text { Ziekenh. loygieniste }\end{array}$ & Magazijn & $\begin{array}{l}\text { Magazijn } \\
\text { Ziekenh. hygieniste }\end{array}$ & Magazijn & $\begin{array}{l}\text { Magazijn } \\
\text { Ziekenh. hygien. }\end{array}$ \\
\hline Personcelszaken & Personeelszaken & & & \\
\hline
\end{tabular}

Personeelszaken Personeelszaken

Andere afdelinger

Admirnistratie

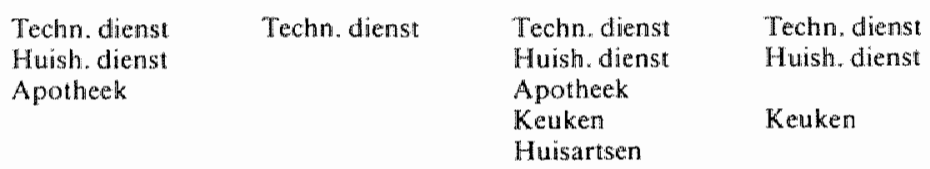

3. Dagelijks voerkomend, soms aangewezen tot de eerste 5 contacten

\begin{tabular}{|c|c|c|c|c|}
\hline Pastor & Pastor & Pastor & Pastor & Pasitor \\
\hline Huisartsen & Huistartsen & Huisartsen & & Huisartsen \\
\hline Apotheek & & Apotheek & & Apotheek \\
\hline Directie & Directie & & & \\
\hline Huish , dienst & Keuken & Muish, dienst & & \\
\hline & Administratio & & Administratie & Administratie \\
\hline & Dietiste & $\begin{array}{l}\text { Personeelszaken } \\
\text { Diëtiste }\end{array}$ & $\begin{array}{l}\text { Personeelszaken } \\
\text { Diëtiste }\end{array}$ & Personeelszaken \\
\hline & Ziekenh. bygiëniste & & Ziekenh, hygiëniste & \\
\hline Techn . dienst. & & Andere afdelinger & & \\
\hline
\end{tabular}

4. Dagelijks voorkomend, vaak aangewezen tot de eerste 5 contacten

\begin{tabular}{|c|c|c|c|c|}
\hline \multirow{9}{*}{$\begin{array}{l}\text { Wijkverpleging } \\
\text { Fysiotherapie } \\
\text { Opleiding } \\
\text { Maatsch. werk } \\
\text { C.H.V./A.H.V. } \\
\text { Dientiste }\end{array}$} & \multirow{9}{*}{$\begin{array}{l}\text { Wijkverpleging } \\
\text { Fysiotherapie } \\
\text { Opleiding } \\
\text { Maatsch. werk } \\
\text { Röntgenalfdeling } \\
\text { L.tboratoriun } \\
\text { Andere afdelingen }\end{array}$} & \multirow{2}{*}{$\begin{array}{l}\text { Wijkverpleging } \\
\text { Fysiotherapie }\end{array}$} & \multirow{3}{*}{$\begin{array}{l}\text { Wijkverpleging } \\
\text { Fysiotherapie } \\
\text { Opleiding }\end{array}$} & \multirow{2}{*}{$\begin{array}{l}\text { Wijkverpleging } \\
\text { Fysiotherapie }\end{array}$} \\
\hline & & & & \\
\hline & & Opleiding & & Opleiding \\
\hline & & \multicolumn{3}{|l|}{ Maatsch. werk } \\
\hline & & C.H.V.AA.H.V. & C.H.V./A.H.V. & $\begin{array}{l}\text { C.H.V./A.H.V. } \\
\text { Diètiste }\end{array}$ \\
\hline & & \multirow{3}{*}{$\begin{array}{l}\text { Röntgenafdeling } \\
\text { Laboratorium }\end{array}$} & Röntgenafdeling & Röntgenafueling \\
\hline & & & & Laboratorium \\
\hline & & & Andere afdielingen & Andere afdeling. \\
\hline & & Directie & $\begin{array}{l}\text { Directic } \\
\text { Operatiekamer }\end{array}$ & $\begin{array}{l}\text { Directie } \\
\text { Operatiekamer }\end{array}$ \\
\hline
\end{tabular}

Keuken

Administratie

5. Dagelijks roorkomend, zeer wak aangewezen tot de eerste 5 contacten

$\begin{array}{lllll}\text { Specialisten } & \text { Specialisten } & \text { Specialisten } & \text { Specialisten } & \text { Specialisten } \\ \text { Operatiekamer } & \text { Operatiekamer } & \text { Operatiekamer } & & \\ \text { Laboratorium } & & & \text { Laboratorium } & \\ \text { Röntgenafdeling } & & \text { Maatsch. werk } & \text { Maatsch. werk }\end{array}$

C.H.V.JA.H. . 
Uit het voorafgaande overzicht kunnen wij het volgende concluderen: het begeleiden van co-assistenten en het verzorgen van de lessen voor de opleiding beschouwen role-setgroepen unaniem als een taak die niet dagelijks wordt uitgeoefend. Zij moemen deze taak ook niet tot de vijf belangrijkste. Over het spreekuur voor bezoekers zijn de meningen verdeeld. Specialisten, gediplomeerden en leerlingen zeggen slechts zelden dat deze taak tot de functie van hoofdverpleegkundigen behoort, maar de hoofdverpleegkundigen en hun directe superieuren denken daar anders over.

Het beheer van de medicijnen drukt kennelijk niet zwaar op de schouders van hoofdverpleegkundigen; zij én de directe superieuren beschouwen het weliswaar als een dagelijkse taak, die evenwel niet vaak tot de eerste vijf wordt gerekend. Gediplomeerden, leerlingen en specialisten zeggen echter vaker dat het beheer van medicijnen één van de vijf belangrijkste taken is van het afdelingshoofd.

De opname en ontslag van patiënten beschouwen specialisten en gediplomeerden minder vaak een belangrijke taak van hoofdverpleegkundigen dan hoofdverpleegkundigen, directe superieuren en leerlingen aangeven.

Een bureaucraat kan de hoofdverpleegkundige nauwelijks worden genoemd, tenminste voorzover bureaucratie staat voor het handhaven van de ziekenhuisvoorschriften. De hoofdverpleegkundigen vinden het niet vaak nodig deze taak tot de vijf eerste te rekenen. Specialisten en gediplomeerden kruisen deze taak vaker aanalséén van de vijf belangrijkste en de directe superieuren scoren daarbij het hoogst.

Het stimuleren van verpleegkundige ontwikkelingen wordt door alle groepen regelmatig genoemd als een belangrijke taak van hoofdverpleegkundigen. Directe superieuren zeggen vaker dan anderen dat deze taak behoort tot de vijf belangrijkste. Rapportage en registratie noemen alle role-setgroepen een belangrijke taak. Datzelfde geldt voor het personeelsbeleid en het zorg dragen voor een adequate personeelsbezetting. Hoofdverpleegkundigen vinden laatstgenoemde taak zelfs zeer belangrijk.

Het begeleiden van het artsenbezoek zien specialisten, gediplomeerden en leerlingen méér dan hoofdverpleegkundigen en directe superieuren als een belangrijke taak van het afdelingshoofid.

Unaniem zeggen role-setgroepen dat de drie belangrijkste taken van het afdelingshoofd zijn: coördinatie van werkzaamheden, het handhaven van een prettige werksfeer en het begeleiden van de patiënt.

Het abserveren van de patiënt wordt in deze categorie genoemd door hoofdverpleegkundigen, specialisten en gediplomeerden. Ook het behandelingsplan uitleggen en laten uitvoeren noemen alle role-setgroepen (met uitzondering van hoofdverpleegkundigen) één van de vijf voornaamste taken van het afdelingshoofd.

Over de contacten kunnen wij het volgende zeggen.

De contacten tussen hoofdverpleegkundigen en ondernemingsraad, arbeidstherapie, gastvrouwen en psycholoog zijn volgens alle role-setgroepen niet frequent en behoren volgens hen niet vaak tot de vijf belangrijkste. Wel frequent zijn de contacten tussen hoofdverpleegkundigen en het magazijn en alle groepen beschouwen dit contact ook als enigszins belangrijk. 
Alle role-setgroepen zeggen dat hoofdverpleegkundigen contacten onderhouden met personeelszaken en technische dienst. Hoofdverpleegkundigen en directe superieuren vinden het contact met personeelszaken niet vaak éen van de vijf voornaamste; daarentegen zeggen specialisten, gediplomeerden en leerlingen meerdere malen dat dit contact tot de vijf belangrijkste behoort. Bij de technische dienst blijken juist hoofdverpleegkundigen, méér dan anderen geneigd, dit contact als een van de vijf woornaamste te beschouwen.

De contacten tussen hoofdverpleegkundigen en directie behoren - volgens hoofdverplleegkundigen en directe superieuren-meestal niet tot de vijf belangrijkste. Daarentegen zegt een aantal specialisten ( $32 \%)$, gediplomeerden (22\%) en leerlingen (31\%) dat dit contact één van de vijf voornaamste is.

De contacten tussen hoofdverpleegkundigen en wijkwerpleging, fysiotherapie en opleiding worden door alle role-setgroepen als belangrijk beschouwd. Ook worden in dit verband contacten genoemd met röntgenafdeling en laboratorium. Hoofdverpleegkundigen beschouwen de twee laatstgenoemde contacten vaak als behorend tot de groep van de vijf belangrijkste.

Unaniem noemen role-setgroepen het contact tussen hoofdverpleegkundigen en specialisten als één van de vijf voornaamste. Hiertoe behoren volgens hoofdverpleegkundigen, directe superieuren en specialisten ook decontacten met de operatiekamer. Het maatschappelijk werk wordt door gediplomeerden en leerlingen beschouwd als één van de vijf belangrijkste contacten. Hoofdverpleegkundigen, directe superieuren en specialisten plaatsen dit contact niet zo hoog op de prioriteitenlijst.

In de taken- en contactenclassificaties zien wij dus tamelijk consistente antwoorden op de vraag: "Wat zijn de taken/contacten van hoofdverpleegkundigen en wat zijn de vijf belangrijkste?", role-setgroepen hebben tamelijk eensluidende meningen. Juist aan de uiterste zijden convergeren de meningen, daar tussenin zien we wel wat nuanceverschillen, doch eigenlijk zo gering dat wij niet kunnen spreken van onderlinge onenigheid.

Nogmaals wijzen wij op de beperkingen van deze analyse. Deze richt zich namelijk op groepsmeningen. Verschil van opvattingen en visies binnen een rolpaar of binnen een role-set komen in dit verband niet ter sprake. Wel echter in het nu volgende, waarin onze studie zich richt op rolparen en role-sets.

Dimensies die role-setleden onderscheiden in de taken en contacten van hoofdverpleegkundigen

Wij verrichtten factoranalysen op de eerder besproken antwoorden op vragen naar taken en contacten. Daar bepaalde taken en contacten door alle hoofdverpleegkundigen werden aangekruist als behorend tot hun werkterrein, ontstonden variabelen zonder variatie, terwijl variatie juist een voorwaarde is voor het kunnen uitvoeren van factoranalysen. Het was mogelijk die variabelen te verwijderen, maar dan ontstonden problemen bij het interpreteren en benoemen van dimensies. Ook onderlinge vergelijkbaarheid verdween. Wij losten dit op door geen factoranalysen uit te voeren op antwoorden van hoofdverpleegkundigen, maar wel op die van rolesenders. 
Tabel 12. Factoranatyse, principale facroren woigens SPSS. Lathgen op de eerste ongerotetrde factor.

Factoranalyse taken hoofd verpleegkundigen

1. Coördinatie werk

2. Personeelsbezeting

3. Rapportage

4. Personeelsbeleid.

5. Beheer medicijnen

6. Begeleiding leerlingen

7. Begelleiding co-issistenten

8. Contacten opleiding

9. Lessen opleiding

10. Verpleegkundige ontwikkelingen

11. Begeleidero artsenbezoek

12. Behandelingsplan

13. Observeren patienten

14. Opname/ontslag patient

15. Begeleiden patient

16. Begelleiding fam. pationt

17. Prettige werksfeer

18. Regels handhaven

19. Deelname aan vergaderingen

20. Spreekuur bezoekers
Directe Specialisten superieuren

$\begin{array}{llll}.88 & .91 & .63 & .79 \\ .50 & .65 & & .49 \\ .83 & .82 & .47 & .64 \\ .59 & .76 & .47 & .80 \\ .78 & .82 & .40 & .54 \\ .62 & .82 & .42 & .48\end{array}$

Gediplow Leerlingen meerden

.59

$.46 \quad .61$

$.80 \quad .82$

$.40 \quad .42$

$\begin{array}{llll}.83 & .84 & .60 & .64\end{array}$

$\begin{array}{llll}.80 & .96 & .68 & .68\end{array}$

$\begin{array}{llll}.68 & .75 & .45 & .63\end{array}$

$\begin{array}{llll}.85 & .96 & .58 & .66\end{array}$

$\begin{array}{llll}.81 & .88 & .56 & .67\end{array}$

$\begin{array}{llll}.85 & .90 & .60 & .68\end{array}$

$\begin{array}{lll}.82 & .80 & .68\end{array}$

$\begin{array}{llll}.85 & .84 & .70 & .67\end{array}$

Verklaarde variantie van de eerste factor (ongeroteerd)

$49 \%$

.41

Tabel 13. Factoranalyse, principale fachoren volgens SPSS. Ladingen op de eerste ongerotedre factor.

Factoranalyse contacten hoofdverpleegkundigen

1. Operatiekamer

2. Röntgenafdeling

3. Laboratorium

4. Andere afdelingen

5. Fysiotherapie

6. Arbeidstherapie

7. Keuken

8. Huishoudelijke dienst

9. Matschappelijk werk

10. Pastor

11. Personeelszaken

12. Technische dienst

13. Administratie

14. Specialisten

15. Huisartsen

16. Directie

17. Magazijn

18. Gastvroumen

19. Opleiding

20. Psycholoog

21. Dietiste

22. Ondernemingsraad

23. Apotheek

24. Wijkverpleging

25. Ziekenhuishygienniste

26. C.H.V.A.H.V.

$\begin{gathered}\text { Directe } \\ \text { superieuren }\end{gathered}$
Specialisten Gediplo- Leerlingen
meerden

.47

.72

.83

.73

.86

.60

.68

.52

.77

.40

.46

.53

.46

$.48 \quad .75$

.40

.63

.67

$.53 \quad .70$

.64

$\begin{array}{ll}.65 & .67\end{array}$

.42

.61

.47

.54

.43

.59

.42

.48

.49

.65

.44

$.52 \quad .57$

$.53 \quad .51$

.57

.68

.52

.51

.67

.58

.62

.63

.56

.43

.54

.42

.45

.74

.57

.74

.63

.73

.54

.53

.67

.45

.48 
Factor analysen taken hoofdverple egkundigen

Uit de factor analysen (ongeroteerd) blijkt dat bij role-senders zoveel ladingen op de eerste factor woorkomen, dat deze moeilijk in zinnig benoembare dimensies zijn samen te vatten. Daarom probeerden wij te roteren naarinzichtelijke dimensies. Dat leverde geen resultaat. Vandaar dat wij volstaan met het presenteren van de eerste, ongeroteerde factor. "De hoofdverpleegkundige als duizend poot" is nog het meest toepasselijke etiket waarmede wij de eerste factor kunnen duiden.

De hoge verklaarde varianties van de eerste factor bij directe superieuren, maar vooral bij specialisten, wijzen op een één-dimensionale visie van superieuren en specialisten ten aanzien van taken van hoofdverpleegkundigen. Zij kruisen alles, of weinig of niets aan wanneer zij het takenpakket van hoofdverpleegkundigen weergeven. Bij leerling-verpleegkundigen en bij gediplomeerden zien wij hetzelfde, zij het in wat mindere mate.

Duidelijke antwoordpatronen ontbreken. Hieruit leiden we af dat role-senders de taak van hoofdwerpleegkundigen ervaren als diffuus en weinig gestructureerd.

\section{Factoranalysen contacten hoofdverpleegkundigen}

Opnieuw zien we bij role-senders zulke diverse contacten op één factor laden (ongeroteerd) dat wij moeten afzien van het benoemen van deze "dimensie". Ook de rotatie naar meer inzichtelijke dimensies leverde geen resultaten. Daarom presenteren wij hier - evenals bij de taken - de ongeroteerde eerste factor.

Duidelijke antwoordpatronen ontbreken. Wij trekken hieruit dezelfde conclusie als bij de bovengenoemde taken: role-senders ervaren de contacten die hoofdverpleegkundigen beroepshalve dagelijks onderhouden als weinig gestructureerd.

\section{Overeenstemming tussen rolparen over vijf belangrijkste taken/contacten van hoofd- verpleegkundigen}

Eerder in dit hoofdstuk beschreven wij de opvattingen van groepen over de taken/contacten van hoofdverpleegkundigen. Het is niet denkbeeldig dat op een algemeen niveau sprake is van een al of niet gelijkgestemde verwachting, maar dat binnen role-sets en rolparen de situatie anders ligt.

Als bijwoorbeeld $27 \%$ van de gediplomeerden zegt het contact tussen hoofdverpleegkundigen en röntgenafdeling tot de vijf belangrijkste te rekenen, betekent dat nog niet dat hun afdelingshoofden dezelfde mening zijn toegedaan. Het is ook best mogelijk dat hoofdverpleegkundigen uit een andere role-set dat contact wel belangrijk vinden, terwijl de gediplomeerden in hun omgeving dat contact minder hoog waarderen.

In deze paragraaf gaan wij wat nauwlettender de taakverwachtingen en taak(on)duidelijkheden tussen rolparen analyseren. De gegevens die wij hieruit verkrijgen noemen wij "gezamenlijke taak(on)duidelijkheid". De meting hiervan bespraken wij in hoofdstuk 4.

De gezamenlijke taak(on)duidelijkheid verdelen we in de volgende categorieën: 0-1 Geringe mate taakduidelijkheid: hoofdverpleegkundige en rolpartner hebben geen enkele of één taak/contact-overeenkomst. 
2-3 Middelmatige taakduidelijkheid: hoofdverpleegkundige en rol-partmer hebben 2 of 3 taken/contacten-overeenkomsten.

4-5 Sterke mate taakduidelijkheid: hoofdverpleegkundige en rol-partner hebben 4 of 5 taken/contacten-overeenkomsten.

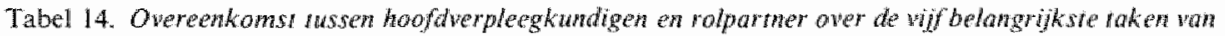
hoofdverpleagktundigen (in procentert).

Hoofdver.f Hoofdwer./ Hoofdver, Hoofdver.

Geringe mate $(0-1)$

Middelnatig $(2-3)$

Sterke mate $(4-5)$

Superiehtir Specialist Gediplorn. Leerting

Gemididelde

21.- $21 .-25 .-\quad 17 .-$

70 - $63 .-64-62$.

9. $\quad 16 .-\quad 11 .-\quad$ 11.-

Standaarddeviatie

2.2

2,3

2,2

2.4

Tabel 15. Overeenkomsten tussen hoofdverpleegkundigen en rolparmers over de vijf belangyijksecontacten wan hoofdverpleegkundigen (im procenten).

\begin{tabular}{|c|c|c|c|c|}
\hline & $\begin{array}{l}\text { Hoofdver./ } \\
\text { Superieut }\end{array}$ & $\begin{array}{l}\text { Hoofdver. } \\
\text { Specialist }\end{array}$ & $\begin{array}{l}\text { Hoofdver./ } \\
\text { Gediplon. }\end{array}$ & $\begin{array}{l}\text { Hoofdwer./ } \\
\text { Leerfing }\end{array}$ \\
\hline Geringe mate $(0-1)$ & $25-$ & 21.- & $25-$ & $29 .-$ \\
\hline Middelmatig $(2-3)$ & $64=$ & $70-$ & $65-$ & $64-$ \\
\hline Sterke mate $(4-5)$ & $11=$ & $9 x-$ & $10 .-$ & $7 .-$ \\
\hline Gemiddelde & 2.1 & 2.2 & 2.2 & 2.- \\
\hline Standaarddeviatie & $1 .-$ & .9 & $1 .-$ & 1.1 \\
\hline
\end{tabular}

Uit bovenstaande tabellen blijkt dat de meeste rolparen zich bevinden in de categorie middelmatige taakduidelijkheid.

Wij vonden geen relatie tussen enerzijds gezamenlijke taak(on)duidelijkheid van hoofdverpleegkundigen en anderzijds ziekenhuisgrootte, role-partner, type aldeling en regio (zie bijlage $1 \mathrm{t} / \mathrm{m}$ 4). Wel vonden wij tussen hoofdverpleegkundigen en specialisten in kleinere ziekenhuizen méér eenstemmigheid over de vijf belangrijkste taken van hoofdverpleegkundigen (gezamenlijke taakduidelijkheid) dan in grotere ziekenhuizen ( $\mathrm{r}-.20$ sign. .05).

Tussen hoofdverpleegkundigen en leerlingen op chirurgische afdelingen bestaat méér gezamenlijke taakduidelijkheid dan tussen hoofdverpleegkundigen en leerlingen op andere afdelingen (Chi-kwadraat 47.8 sign. .005).

Ook vonden wij een relatie tussen gezamenlijke taak(on)duidelijkheid binnen de gehele role-set en type afdeling. Op chirurgie is een grotere gezamenlijke taakduidelijkheid dan op gynaecologie (Chi-kwadraat 89.5 sign. .01).

Hoe is de gemiddelde gezamenlijke taak(on)duidelijkheid per type afdeling? 


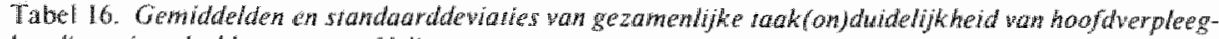
kandigen, ingedeeld naar type afdeling.

TAKEN

Gemiddelide s.d.
CONTACTEN

Geniddelde s.d.

\section{Chirurgie}

Hoofdwerplecgkundige-superieur

Hoofdverplecgkundige-specialist

2.3

2.2

2.3

Hoofdverpleegkundige-gediplomeerde

Hooldverpleckkundige-leerling

2.9

1.1
$1 .-$
.9
.7

2.2

2.4

1.8

2.1

1.2

.8

.8

Interne

Hoofdverpleegkundige-superieur

Hoof tverplegkundige-specialist

Hoof dverpleegkundige gediplomeerde

Hoof dverpleegkundige-leerling

Gynaecologit/Obstetrie

Hoofdverpleegktundige-superieur

Hoofdverpleegk undige-specialist

2.2

.92

2.2

$\begin{array}{ll}1.2 & 2.2 \\ 1 .- & 2.2\end{array}$

Hoofdwerpleegkundige-gediplomeerde

Hoofdverpleegkundige-leerling

Overige afdelingen

Hoofdverpleegkundige-superieur

Hoofdverpleegk undige-specialist.

Hooldverpleegkundige-gediplorneerde

Hoofdverpleegkundige-leerling

Hoewel de verschillen in bovenstaande tabel niet erg spectaculair zijn, kunnen wij toch het een en ander opmerken.

Op bijna alle afdelingen blijven rolparen in het gebied waar sprake is van middelmatige taakduidelijkheid. Uitzondering vormen de contactovereenkomsten bij chirurgische afdelingen tussen hoofdverpleegkundigen en gediplomeerden. Bij de overige afdelingen zien we een geringe taakduidelijkheid tussen drie van de vier rolparen: hoofdverpleegkundigen-specialisten, hoofdverpleegkundigen-gediplomeerden en hoofd verpleegkundigen-leerlingen.

Het is niet zo dat steeds een bepaald rolpaar het meeste overeenkomst heeft, dat wisselt per afdeling. Zo blijken op de chirurgische afdeling de leerling-verpleegkundigen nog de meeste overeenstemming te bereiken met hoofdverpleegkundigen over de taak, maar op de gynaecologische afdeling (taakgemiddelden) zijn het de specialisten die de eerste positie innemen. Hoofdverpleegkundigen en specialisten hebben op de chirurgische afdeling die minste overeenstemming over de taak; op de interne afdeling ligt het grootste verschil tussen hoofdverpleegkundigen en directe superieuren; op de gynaecologische en de "overige" afdelingen tussen hoofdverpleegkundigen en gediplomeerden.

Wat de contacten betreft liggen hier de gemiddelden over het algemeen lager dan bij de taken. Dit is in overeenstemming met onze verwachtingen. Bij het analyseren van de door de role-setleden genoemde vijf belangrijkste taken en contacten zagen wij 
namelijk meer onderlinge overeenstemming bij taken dan bij contacten. Binnen de afdelingen winden wij geen rolparen die consistent de meeste of minste overeenstem ming bereiken met de meningen van hoofdverpleegkundigen. Indien gezamenlijke taak(on)duidelijkheid persoons- of groepsgebonden zou zijn, hadden we waarschijnlijk meer eenduidige verschillen of overeenkomsten aangetroffen, bijvoorbeeld steeds een hogere score tussen hoofdverpleegkundigen en gediplomeerden en een lagere score tussen hoofdverpleegkundigen en leerlingen. Nu dit niet het geval is, gaan we vermoeden dat gezamenlijke taak(on)duidelijkheid méer per specialisme werschilt dan per beroepscategorie. Om hierover meer informatie te krijgen, gaan we na of er significante verschillen bestaan tussen dezelfde rolparen op diverse afdelingen ( $t$-test).

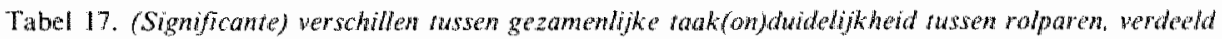
naar type afdeling.

\section{Chirurgie/Internen Hoofdw.-superieur Hoofdw -specialist \\ +H Hoordr.-gediplom. \\ + Hoofdw-leerling}

\section{Chirurgie/Gynateologie}

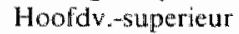

Hoofdv-specialist

Hooldv.-gediplom.

+ Hooldv,-leerling

\section{Chirurgie/Overige}

Hoofdw.-superieur

Hoofd $x_{\text {-specialist }}$

Hoofdw-gediplom.

Hoofdr.-leerling

\section{Internen/Gynaecologie}

Hoofdv-superieur

+ Hoofdr-specialist

Hoofdv.-gediplom.

- Hoofdv leerling

Internen/Overige

Hoofdv -superieur

Hoofdv.-specjalist

Hoofdv.-gediplom.

Hoofdv.meerling

Gynaecologie/Overige

\section{Hoofdv.-superieur}

- Hoofdv-specialist

+ Hoofdv,-gediplom.

Hoofdv.-leerling

\section{TAKEN}

Gemiddelde T-waarde

2.3/2.-

$2.2 / 2.4$

$2.3 / 2.4$

$2.9 / 2.3$

$2.3 / 2.2$

$2.2 / 2.3$

2.3/2.-

$2.9 / 2.2$

$2.3 / 2.2$

$2.2 / 2.2$

$2.3 / 2$ -

$2.9 / 2.2$

2. $-/ 2.2$

$2.4 / 2.3$

2.4/2.-

$2.3 / 2.2$

$2 .-1 / 2.2$

$2.4 / 2.2$

2.4/2.-

2. $3 / 2.2$

.87
-.59
-.25
2.17

2.17
Sign.

$$
\text { n..5. }
$$

n.s.

.05

$\begin{array}{ll}\text { n.s. } & 2.2 / 2.2 \\ \text { n.s. } & 2.3 / 2.2 \\ \text { n.s. } & 1.8 / 2.2 \\ .005 & 2.1 / 2 . \cdots\end{array}$

n.s.

n.s.

n.s.

.05

$2.2 / 2.1$

$2.4 / 1.8$

$1.8 / 1.8$

$2.1 / 1.7$

2.22

-.52
.30
.89
.51

n.

เท.5.

n.s.

nin.s.

2. -12.2

$2.4 / 2.2$

$2.8 / 2.2$

2.1/2.-

-.44
2.39
3.43
1.01

$-.92$

.63

1.96

.42

1...s.

n.s.

n.s.

n.s.

$2.2 / 2.2$

2.3/2.2

2.- $/ 2$.-

$2.2 / 2.2$

$\begin{array}{ll}\text { n.s. } & 2 .-/ 2.1 \\ \text { n.s. } & 2.4 / 1.8 \\ \text { n.s. } & 2.8 / 1.8 \\ \text { n.s. } & 2.1 / 1.7\end{array}$

$$
\begin{array}{r}
-.47 \\
.62 \\
.91 \\
.29
\end{array}
$$

$\begin{array}{rrr}.00 & 0.5 . & 2.2 / 2.1 \\ .28 & 11.5 . & 2.2 / 1.8 \\ .00 & n .5 . & 2.2 / 1.8 \\ -.15 & \text { n.s. } & 2 .-11.7\end{array}$

$\begin{array}{rr}.31 & \text { n.s. } \\ 1.37 & \text { n.s. } \\ 1.08 & \text { n.s. } \\ .70 & \text { n.s. }\end{array}$

Uit tabel 17 blijkt dat er zeven significante verschillen bestaan tussen dezelfde rolparen op verschillende afdelingen. 
- Er is meer gezamenlijke taakduidelijkheid (wat betreft de contacten) tussen hoofdverpleegkundigen en gediplomeerden op interne afdelingen dan op chirurgische afdelingen.

- Er is meer gezamenlijke taakduidelijkheid (wat betreft de taken) tussen hoofdverpleegkundigen en leerlingen op chirurgische afdelingen dan op interne afdelingen.

- Er is meer gezamenijke talakduidelijkheid (wat betreft de taken) tussen hoofdverpleegkundigen en leerlingen op chirurgische afdelingen dan op gynaecologische afdelingen.

- Er is meer gezamenlijke taakduidelijkheid (wat betreft de contacten) tussen hoofdverpleegkundigen en specialisten op chirurgische afdelingen dan op "overige" afdelingen.

- Er is meer gezamenlijke taakduidelijkheid (wat betreft de taken) tussen hoofdverpleegkundigen en leerlingen op chürurgische afdelingen dan op "overige" afdelingen.

- Er is meer gezamenlijke taakduidelijkheid (wat betreft de contacten) tussen hoofdverpleegkundigen en specialisten op interne afdelingen dan op "overige" afdelingen.

- Er is meer gezamenlijke taakduidelijkheid (wat betreft de contacten) tussen hoofdverpleegkundigen en gediplomeerden op interne afdelingen dan op "overige" afdelingen.

De afdeling chirurgie komt viermaal positief naar voren en eenmaal negatief. De "overige" afdelingen komen viermaal negatief naar voren.

Wij vermoeden dat op chirurgische afdelingen wat méér gezamenlijke taakduidelijkheid aanwezig is dan op de "overige" afdelingen.

Ook vermoeden wij dat gezamenlijke taakonduidelijkheid méér specialisme gebonden dan groepsgebonden voorkomt. Wij kunnen hier echter - gezien de aard van de gegevens - geen duidelijke uitspraken over doen.

Wel mogen wij zeggen dat er middelmatige gezamenlijke taakduidelijkheid bestaat tussen hoofdverpleegkundigen en role-senders.

Wij kunnen geen groepen aanwijzen waarmede hoofdverpleegkundigen méer of minder gezamenlijke taak(on)duidelijkheid hebben.

Wij vonden geen significante verschillen tussen gezamenlijke taak(on)duidelijk heid en diverse ziekenhuisgrootten en gezamenlijke taak(on)duidelijk heid en regio's (zie bijlage ( en 4).

Overeenstemming birnen de gehele role-set over vijf belangrijkste taken/contacten van hoofdverpleegkundigen

Wij gingen na hoe binnen de gehele role-set de gezamenlijke taak(on)duidelijkheid scoort. Wij groepeerden als volgt:

$0-3$ Zeer geringe mate taakduidelijkheid: hoofdverpleegkundigen en rolsenders hebben drie of minder taken/contacten-overeenkomsten.

4-7 Geringe mate taakduidelijkheid: hoofdverpleegkundige en role-senders hebben 4 tot en met 7 taken/contacten-overeenkomsten. 
8-11 Middelmatige taakduidelijkheid: hoofdverpleegkundige en role-senders hebben 8 tot en met 11 taken/contacten-overeenkomsten.

12-15 Sterke mate taakduidelijkheid: hoofdverpleegkundige en role-senders hebben 12 tot en met 15 taken/contacten-overeenkomsten.

16-20 Zeer sterke mate taakduidelijkheid: hoofdverpleegkundige en role-senders hebben 16 of meer taken/contacten-overeenkomsten.

Tabel 18. Oxereenkomsten tussen hoofderplecklundigen en role-senders ower de vijbetongrijkste saken van hoofdwerpleegkundigen (in procenten).

Hootdverpleegkundige/nol-senders
Zeer geringe mate
Geringe mate
Middelmatig
Sterke mate
Zeer sterke mate
$(0-3)$
$(4-7)$
$(8-11)$
$(12-15)$
$(16-20)$

Gerniddelde
$4 .-$
$18 .-$
$16 .-$

8.9

Standaarddeviatic

2.8

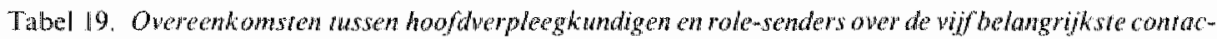
ren wan haofdverpleegkundigen (in procenten).

Hooldwerpleeglkundige/role-senders

$\begin{array}{lcc}\text { Zeer geringe mate } & (0-3) & 12,- \\ \text { Geringe nate } & (4-7) & 30- \\ \text { Middelmatig } & (8-11) & 47 .- \\ \text { Sterke mate } & (12-15) & 11- \\ \text { Zeer sterke mate } & (16-20) & -\end{array}$

Gemiddeldie

7.7

Standaarddeviatie

3.6

Uit de tabellen 18 en 19 blijkt dat binnen de totale role-set sprake is van middelmatige taakduidelijkheid. Bij de taken zien we meer overeenkomsten dan bij de contacten.

Wij zochten naar significante verbanden tussen enerzijds gezamenlijke taak(on)duidelijkheid en anderzijds ziekenhuisgrootte, type afdeling en regio. Wij vonden geen relaties met ziekenhuisgrootte en regio, wel een relatie met een type ziekenafdeling. Op chirurgie is namelijk onder de totale role-set een grotere gezamenlijke taakduidelijkheid dan op gynaecologie (Chi-kwadraat 89 sign. .01).

Ook zochten wij naar significante verschillen tussen gezamenlijke taak(on)duidelijkheid binnen de gehel role-set en ziekenhuisgrootte, type afdeling en regio. Wij vonden echter geen enkel significant verschil. 
5.4 Verbanden tussen gezamenlijke taak(on)duidelijkheid en ervaren rol(on)duidelijk heid

In hoofdstuk 3 hebben wij uiteengezet dat "taak" en "rol" verschillende begrippen zijn. Het zijn wel begrippen die een nauwe relatie met elkaar hebben. Daarom denken wij verbanden te mogen veronderstellen tussen gezamenlijke taak(on)duidelijkheid en ervaren rol(on)duidelijkheid.

Het al of niet kunnen aantonen van relaties heeft praktische consequenties. Bij aanwezigheid van verbanden tussen gezamenlijke taak(on)duidelijkheid en ervaren rol(on)duidelijkheid is het haast vanzelfsprekend dat ziekenhuisdirecties, die rolonduidelijkheid onder hoofdverplleegkundigen willen verminderen, zich onder meer zullen toeleggen op het nau wkeurig omschrijwen van taken/contacten van afdelingshoofden.

Indien in dit onderzock geen relaties worden gevonden tussen gezamenlijke taak(on)duidelijkheid en ervaren rol(on)duidelijkheid, veronderstellen wij dat goede functieomschrijvingen heel wat minder belangrijk zijn om de problemen op telossen.

De ervaren rol(on)duidelijkheid van hoofdverpleegkundigen (VOS $1 \mathrm{t} / \mathrm{m}$ 6) gaan wij in verband brengen met gezamenlijke taak(on)duidelijkheid tussen de rolparen: hoofdverpleegkundigen en superieuren; hoofdverpleegkundigen en specialisten; hoofdverpleegkundigen en gediplomeerden en hoofdverpleegkundigen en leerlingen. De scores van de variabelen lopen niet in dezelfde richting.

Gezamenlijke taakonduidelijkheid/duidelijkheid scoort $0-5$, ervaren rolonduidelijkheid/duidelijkheid scoort $15-0$. Wij verwachten bij een hoge gezamenlijke taakonduidelijkheid tevens een hoge ervaren rolonduidelijkheid. Gezien de scoreverloop verwachten wij dus een negatieve correlatie tussen beide variabelen.

Tabel 20. Correlatie tussen gezamenlike takkonduidelikheid en erwaren rolonduidelijkheid, war betreft raken en contacten.

$\begin{array}{llll}\text { Hoofdverpl./ } & \text { Hoofdverpl./ } & \text { Hoofdverpl./ } & \text { Hoofdverpl./ } \\ \text { superieur } & \text { specialist } & \text { gediplom. } & \text { Role-set }\end{array}$

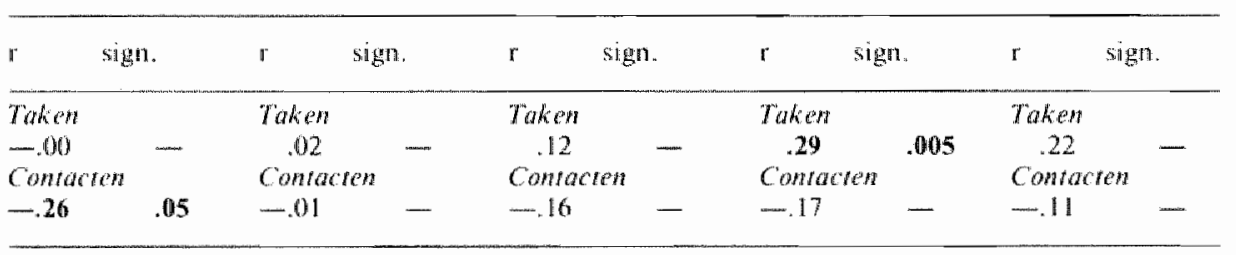

Uit bovenstaande tabel blijkt dat er slechts twee significante correlaties zijn, waarvan éen in een richting, tegengesteld aan de verwachte loopt (hoofdverpleegkundige/ leerling). Dat betekent dat als hoofdverpleegkundigen zeggen dat zij rolonduidelijkheid ervaren, er sprake is van gezamenlijke taakduidelijkheid tussen hen en leerlingen. Bij contacten zien we de verwachte negatieve correlaties, maar slechts één is significant.

Hoe kunnen wij deze bevindingen interpreteren? 
Wij wezen enkele malen op het verschil tussen de begrippen "taak" en "rol", maar we zijn er wel van uitgegaan dat taakonduidelijkheid een aspect van rolduidelijk heid is. De bevindingen uit tabel 20 leren ons echter dat gezamenlijke taakduidelijkheid. onvoldoende resulteert in ervaren rolduidelijkheid; in bepaalde gevallen vindt zelfs het tegendeel plaats.

Kan dit liggen aan communicatiedrempels? Zijn de signalen van role-senders niet krachtig genoeg? Wij denken van niet, want dan zou dit ook doorwerken in de contactenaanwijzingen. Daar lopen de verbanden wél in de veronderstelde richting.

Er zijn nog meer empirische bevindingen die de weg naar theoretische interpretaties blokkeren. Wij zouden bijvoorbeeld theoretisch kumnen zeggen dat in het takenschema zoveel belangrijke taken voorkomen, dat de keuze van de role-set betrekkelijk at random is geweest. Bij contacten zou de aanwijzing van de vijf belangrijkste niet zo problematisch zijn, omdat er enkele belangrijke werkelijk witschieten (specialisten, laboratorium, röntgenafdeling). Tegen deze redenering pleit de reeds eerder gesignaleerde tendens van een grotere overeenkomst tussen hoofdverpleegkundigen en role-senders over de vijf belangrijkste taken dan omtrent de vijf belangrijkste contacten (hoewel dat verschil niet groot is).

Wij vermoeden dat ervaren rolonduidelijk heid - veel méér dan wij aanvankelijk aannamen - slaat op gedragsrelevante aspecten en die gedragsrelevante aspecten komen méer tot uiting in taken (en hoe die in te vullen) dan in het leggen van contacten. Als hoofdverpleegkundigen en role-senders het perfect met elkaar eens zijn over de vijf belangrijkste taken, dan weten zij wel het "wat", maar nog niet het "hoe". De gehele role-set kan unaniem van mening zijn dat het begeleiden van de patiënt tot de vijf belangrijkste taken behoort (gezamenlijke taakduidelijkheid) maar ieder kan een andere visie hebben op de manier waarop de taak moet worden uitgevoerd (rolonduidelijkheid).

Behandelings- en verzorgingsideologieën, leiderschapsstijl, personeelsbeleid, prettige werksfeer en verpleegkundige ontwikkelingen stimuleren zijn niet in taakomschrijvingen te vatten. De verschillende visies daarop kunnen aanleiding geven tot grote ervaren rolonduidelijkheid van hoofdverpleegkundigen.

Ook de steeds groter wordende autonomie van verschillende beroepsgroepen rondom de patiènt behoeft niet de taakduidelijkheid, maar kan wel de rolduidelijkheid van hoofdverpleegkundigen beïnvloeden. Hoe zal het afdelingshoofd verschillende werkzaa mheden coördineren (taakduidelijkheid) als een aantal functionarissen niet komt opdagen? Welk gedrag is dan relevant (rol-onduidelijkheid)?

De bevindingen suggereren dat, willen ziekenhuisdirecties rolonduidelijkheid van hoofdverpleegkundigen bestrijden, zij niet alleen kunnen volstaan met een goede taak- of functiebeschrijving. Er dient ook helderheid te komen in onderliggende begrippen en basisfilosofieèn. Ook de autonomie van in het ziekenhuis werkzame beroepsgroepen dient te worden doorgelicht en waar nodig afgezwakt. 


\subsection{Samenvatting}

Wij hebben omschreven hoe de centrale variabele rolonduidelijk heid werd geoperationaliseerd en gemeten.

Vervolgens zijn wij nagegaan in welke mate hoofdverpleegkundigen rolonduidelijkheid ervaren. Wensen zij méér of minder rolonduidelijkheid? Wij hebben de ervaren en gewenste rol(on)duidelijkheid van hoofdverpleegkundigen vergeleken met die van andere beroepsgroepen en zijn tot de conclusie gekomen dat personeelchefs meer rolonduidelijkheid ervaren dan hoofdverpleegkundigen.

Wat de taak(on)duidelijkheid betreft hebben wij gevonden dat de role-setleden een betrekkelijk eensgezinde mening hebben over de kwestie welke taken en contacten tot de functie van hoofdverpleegkundigen behoren. Ook over de vijf belangrijkste taken/contacten is een redelijke mate van overeenstemming te bespeuren.

Als wij de taaksamenstelling en de prioriteitenstelling met elkaar combineren krijgen wij taken/contacten-classificaties die ons iets zeggen over de nadruk en accenten die sommige groepen leggen. Uit deze analyse blijkt dat visies onderling niet veell verschillen. Unaniem noemen de role-setgroepen als de drie belangrijkste taken van het afdelingshoofd: coördinatie van werkzaamheden, het handhaven van een prettige werksfeer en het begeleiden van de patiënt.

Als de twee minst belangrijke noemen zij het begeleiden van co-assistenten en het verzorgen van lessen voor de opleiding.

Het belangrijkste contact ligt volgens alle role-setgroepen tussen hoofdverpleegkundigen en specialisten. De contacten die het minste worden genoemd zijn die met de ondernemingsraad, arbeidstherapie, gastvrouwen en psycholoog.

Wij hebben gezocht naar mogelijk aanwezige dimensies in de antwoordpatronen. Daarom hebben wij factoranalysen verricht op de ant woorden van de vraag: "Welke taken en contacten behoren tot de functie van hoofdverpleegkundigen?"

Bij role-senders zien wij zoveel ladingen op de eerste factor dat wij deze niet kunnen benoemen. Hieruit hebben wij geconcludeerd dat taken en contacten van hoofdverpleegkundigen als weinig specifiek en zeer diffuus worden ervaren. Functionarissen waarmede afdelingshoofden samenwerken zien geen duidelijke structuur in de werkzaamheden van hoofdverpleegkundigen.

Daarna zijn we ons gaan oriënteren op rolparen, waarbij de hoofdverpleegkundige als standaard wordt genomen. De hier verkregen gegevens hebben betrek king op de gezamenlijke taak(on)duidelijkheid.

Uit de analyse blijkt dat de overeenstemming tussen rolparen niet erg groot is: er is sprake van een middelmatige gezamenlijke taakduidelijkheid.

Wij hebben geen relatie gevonden tussen gezamenlijke taak(on)duidelijkheid en regio of ziekenhuisgrootte. Wel vermoeden wij dat afdelingstype iets te maken kan hebben met gezamenlijke taak(on)duidelijkheid. Als wij namelijk naar verschillende afdelingstypen kijken, blijken signifficante verschillen aanwezig tussen dezelfde rolparen op verschillen aldelingen. Dit doet vermoeden dat gezamenlijke taak(on)duidelijkheid niet zozeer persoonsgericht, maar meer specialismegericht is. 
Chirurgie komt als de afdeling met de meeste gezamenlijke taakduidelijkheid naar voren. De aanwijzingen zijn echter te zwak om daar stellige uitspraken over te doen. Als wij verbanden zoeken tussen gezamenlijke taak(on)duidelijkheid en ervaren rol(on)duidelijkheid van hoofdverpleegkundigen, blijken slechts twee relaties significant. Eén daarvan is in een richting tegengesteld aan de verwachte. Dit heeft ons tot de conclusie geleid dat ervaren rol(on)duidelijkheid - veel meer dan wij hebben verondersteld - slaat op gedragsrelevante aspecten. Het eens zijn over het "wat" (gezamenlijke taakduidelijkheid) betekent nog niet het eens zijn over het "hoe" (rolduidelijkheid). Juist dit laatste is vaak afwezig. Verschillende visies op concrete werkuitvoering betekenen evenzovele mogelijkheden voor rolonduidelijkheid. Ook door de steeds groter wordende autonomie van verschillende beroepsgroepen weet de hoofdverpleegkundige soms niet welk gedrag relevant is (rolonduidelijkheid) om de haar toebedeelde taken (gezamenlijke taakduidelijkheid) ten uitvoer te brengen.

De bevindingen suggereren dat ziekenhuisdirecties, die de rolonduidelijkheid van hoofdverpleegkundigen willen bestrijden, niet kunnen volstaan met louter taaktechnische aanwijzingen. 



\section{Hoofdstuk 6}

\section{Rolonduidelijkheid van hoofdverpleegkundigen}

In hoofdstuk 3 wezen wij op drie kernaspecten van het rolbegrip: rol veronderstelt een sociale relatie, gedrag en verwachtingen.

Reiche (1982) noemt het niet goed functioneren van die relationele aspecten "rolonduidelijkheid".

Het intermenselijke aspect van rol, rolgedragen rolverwachtingen hebben wij in een viertal vragen geoperationaliseerd. Deze vragen stelden wij aan de gehele role-set, zodat wij zowel de sent-role alsook dle received-role en de discrepanties daartussen kunnen meten.

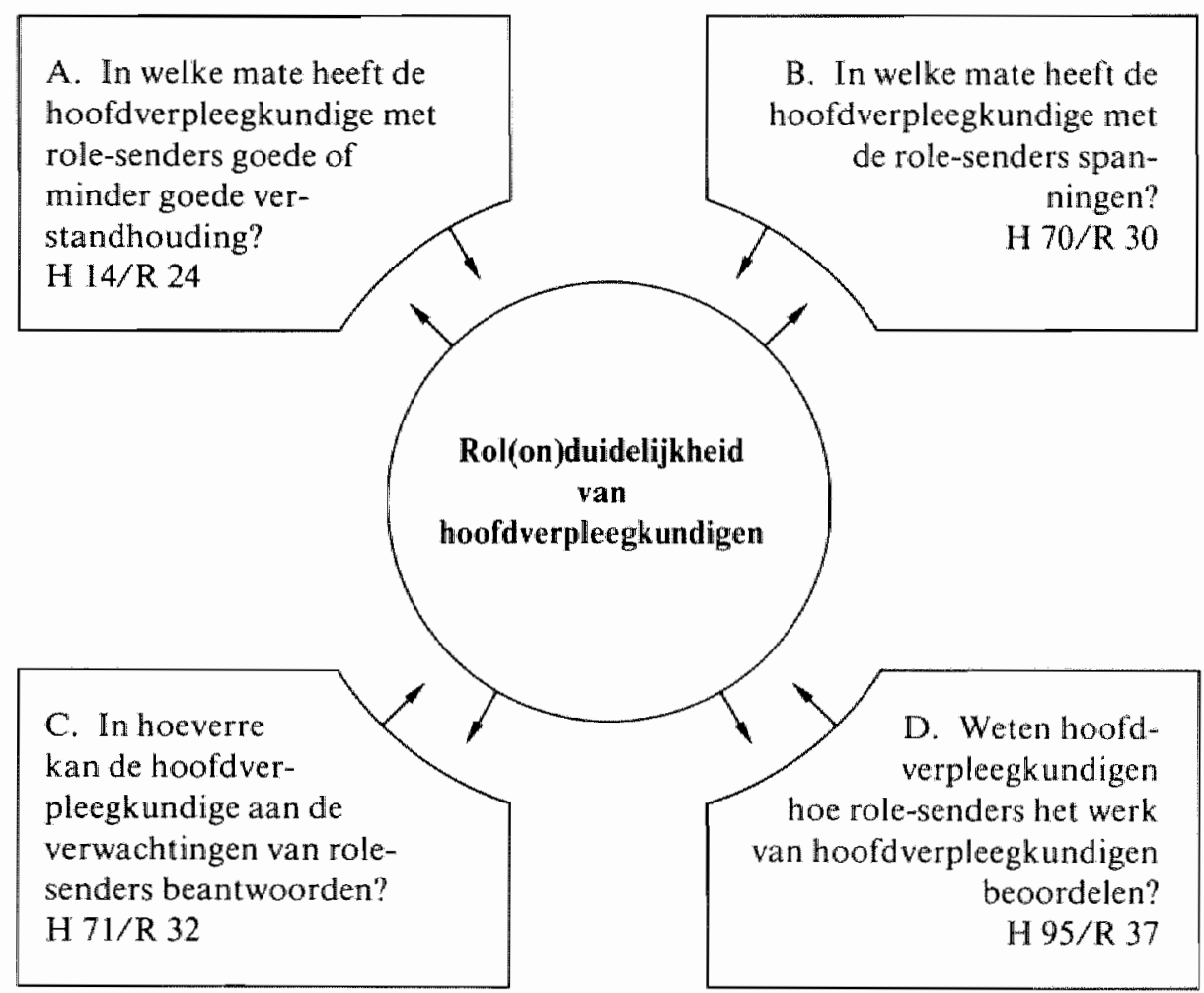

Figuir 7. Interpersoonlijke aspecten die rolgedragingen kunnen beinvloeden. 
De basisgedachten in dit hoofdstuk zijn de volgende. Als meningen van hoofdverpleegkundigen en role-senders over rolrelevante aspecten eensluidend zijn, dan bestaat er gezamenlijke rolduidelijkheid. Bestaan er significante verschillen, dan spreken wij van gezamenlijke rolonduidelijkheid. Dit baseren wij op de volgende overweging. Als er een discontinuitteit bestaat tussen sent-role en received-role, komen interrelationele aspecten, zowel bij hoofdverpleegkundigen alsook bij rolesenders, onduidelijk over. Dit resulteert in gezamenlijke rolonduidelijkheid. Wij analyseren dit in 6.1 .

Het is mogelijk dat gezamenlijke rolonduidelijkheid te wijten is aan hoofdverpleegkundigen die falen in de perceptie van de situatie. Dit trachten wij te achterhalen door de meningen van role-senders onderling te correleren (6.2). Vinden wij daar geen of weinig onderlinge verbanden, dan nemen wij aan dat de gezamenlijke rolonduidelijkheid niet primair kan worden toegeschreven aan gebrekkige opmerkingsgaven van hoofdverpleegkundigen.

Niet alleen de discrepanties tussen de meningen van role-setleden over interpersoonlijke relaties, maar ook de (als ongunstig ervaren) intermenselijke verhoudingen op zich reflecteren rolonduidelijkheid, zie Reiche (1982): "Rolonduidelijkheid kan worden beschouwd als een niet goed functioneren van de interpersoonlijke relatie". Daarom gaan wij in 6.3 na of er correlaties worden gevonden tussen ervaren rolonduidelijkheid van hoofdverpleegkundigen en de (door hoofdverpleegkundigen als minder gunstig ervaren) gedragsrelevante aspecten van rolesenders.

In paragraaf 6.4 beantwoorden we de vraag: "Zijn role-senders zich bewust van de invloed van hun gedragingen op de ervaren rolonduidelijkheid van hoofdverpleegkundigen?" Dit hoofdstuk sluit af met de samenvatting (6.5).

6.1 Verschillen in percepties van hoofdverpleegkundigen en role-senders over rolrelevante aspecten

Een eventueel aanwezige gezamenlijke rolonduidelijkheid tussen hoofdverpleeg$k$ undigen en hun role-senders is weergegeven in tabel 21.

Ter verduidelijking het volgende: wij berekenden op de antwoorden van hoofdverpleegkundigen, directe superieuren, specialisten, gediplomeerden en leerlingen op de viervragen (zie ook figuur 7) de gemiddelden en standaardafwijkingen. Over de onderlinge spanningen (B) verschillen de antwoorden van hoofdverpleegkundigen/ directe superieuren en hoofdverpleegkundigen/specialisten significant (zie de drie laatste kolommen van de tabel). De meningen over de bekendheid met de werkbeoordeling (D) van hoofdverpleegkundigen/directe superieuren en hoofdverpleegkundigen/specialisten en hoofdverpleegkundigen/leerlingen verschillen significant. Over de onderlinge verstandhouding (A) hebben hoofdverpleegkundigen/gediplomeerden en hoofdverpleegkundigen/leerlingen significant verschillen- 
de meningen. Over problemen met onderlinge verwachtingen (C) vonden wij geen significante verschillen in de antwoorden.

Tabel 21. Gemiddelden. standaraddewates en significante verschilen Hasen sociale dimensies ran rot gredrag. Hoge waarden dhiden op ats ongunsig ervaren sinuasies.
A. Minder
B. Spannin *
C. Moellijk
D. Niet op
goede ver-
standhou*
gen met role-
aan verwach de hoogle
ding
setlid. tingen kun
van werk-
nen voldoen beoordeling
door...

\begin{tabular}{|c|c|c|c|c|c|c|c|c|c|c|c|}
\hline & Gem. & s.d. & Gem. & s.d. & Grem. & s.d. & Gen. & - sod. & $\begin{array}{l}\text { T-waar- } \\
\text { den }\end{array}$ & d.t. & $\begin{array}{l}\text { sign. } \\
\text { niveau }\end{array}$ \\
\hline Hoofdverpleegk. & 1.68 & .67 & 1.56 & .82 & 2.16 & .79 & 2.61 & 1.41 & $B-2.35$ & 157 & .02 \\
\hline Superiaturen & 1.74 & .68 & 1.89 & .93 & 2.25 & .90 & 2.02 & .82 & D $\quad 3.21$ & 126 & .002 \\
\hline Hoofdverpleegk. & 1.65 & .75 & 2.09 & 1.10 & 202 & .78 & 2.32 & 1.19 & B 2,91 & 151 & .004 \\
\hline Specialisten & 1.45 & .67 & 1.63 & .86 & 204 & .93 & 1.88 & .79 & D 2.81 & 138 & .006 \\
\hline Hoofdverpleegk. & 1.5 & .55 & 1.85 & .88 & 1.95 & .67 & 2.11 & 1.2 & $A-3.41$ & 147 & .001 \\
\hline Gediplomeerclen & 1.8 & .74 & 1.88 & .83 & 2.15 & .85 & 2.31 & 1.1 & & & \\
\hline Hoofdverpleegk. & 1.69 & .61 & 2.01 & .86 & 2.12 & .69 & 2.45 & 1.19 & $A-2.62$ & 154 & .01 \\
\hline Leerlingen & 1.96 & .68 & 1.81 & .78 & 2.28 & .85 & 2.80 & 1.11 & $\mathrm{D}-1.93$ & 155 & .05 \\
\hline
\end{tabular}

De gegevens uit de tabel kunnen wij als volgt verwoorden.

A. Hoofdverpleegkundigen ervaren de verstandhouding tussen hen en de rolesenders als goed en zelfs als beter dan role-senders percipiëren (uitgezonderd specialisten). Wij zien significante verschillen tussen hoofdverpleegkundigen/ gediplomeerden en hoofdverpleegkundigen/leerlingen. Gediplomeerden en leerlingen hebben een minder gunstige opvatting over hun verstandhouding met de hoofdverpleegkundigen dan de laatsten menen te ervaren.

B. Hoofdverpleegkundigen ervaren wat spanningen met specialisten en leerlingen; in veel mindere mate met superieuren. Deze directe superieuren echter ervaren méêr spanningen met hoofdverpleegkundigen dan de laatsten aangeven. Bij de specialisten is het juist omgekeerd, zij geven aanmerkelijk minder spanningem aan.

Bij het oordeel over hun onderlinge spanningen zien wij significante verschillen tussen zowel hoofdverpleegkundigen/directe superieuren alsook tussen hoofdverpleegkundigen/specialisten. Directe superieuren geven méér onderlinge spanningen aan en specialisten minder dan de hoofdverpleegkundigen ervaren. Wij dienen echter wel te wijzen op de standaarddeviatie bij de spanningen met specialisten. Deze is nogal hoog. Dat betekent dat de antwoorden van hoofdverpleegkundigen een grote spreiding vertonen.

C. Binnen de groep van role-senders maken directe superieuren en leerlingen het de hoofdwerpleegkundigen het moeilijkste om aan de verwachtingen te voldoen. 
Het gemakkelijkste voldoen hoofdverpleegkundigen aan verwachtingen van gediplomeerden, daar tussenin komen de specialisten. De directe superieuren zelf menen ook dat zij nogal wat wan hoofdverpleegkundigen verwachten. Wij zien trouwens bij alle role-senders een hoger verwachtingsgemiddelde dan bij hoofdverpleegkundigen. De verschillen zijn echter niet significant.

D. Veel hoofdverpleegkundigen blijken nauwelijks te weten hoe role-senders hun werk beoordelen. Tevens beseffen veel role-senders dat zij de hoofdverpleegkundige ook te weinig op de hoogte brengen.

Vooral over de werkbeoordeling door directe superieuren, leerlingen en specialisten, blijken hoofdverpleegkundigen in het ongewisse te verkeren (de standaarddeviaties wijzen op aanmerkelijke spreiding). Dit facet van de gezamenlijke rolonduidelijkheid springt het meest negatief naar voren. Drie significante verschillen wijzen op een gezamenlijke rolonduidelijkheid tussen hoofdverpleegkundigen en role-senders (uitgezonderd gediplomeerden).

Samenvattend mogen wij zeggen dat de grootste gezamenlijke rolonduidelijkheid bestaat omtrent de beoordeling van het werk van de hoofdverpleegkundigen door role-senders.

Over de mate van spanningen tussen hoofdverpleegkundigen/directe superieuren en hoofdverpleegkundigen/specialisten bestaan tevens significante verschillen, zodat ook daar gezamenlijke rolonduidelijkheid aanwezig is.

Bij de onderlinge verstandhouding blijken de meningen te verschillen tussen hoofdverpleegkundigen/gediplomeerden en tussen hoofdverpleegkundigen/leerlingen. Deze gezamenlijke rolonduidelijkheid tussen groepen, die dagelijks zo op elkaar zijn aangewezen, lijkt ons een bron van spanningen.

In deze analyse komen twee clusters naar voren. Directe superieuren en specialisten verschillen met hoofdverpleegkundigen over de mate van onderlinge spanningen en duidelijkheid van werkbeoordelingen (B - D). Als tweede cluster zien wij gediplomeerden en leerlingen die over hun verstandhouding $(A)$ een van de hoofdverpleegkundigen afwijkende mening hebben. Leerlingen daarenboven hebben ook nog over de werkbeoordeling (D) een andere opinie dan hoofdverpleegkundigen.

\subsection{Meningen van role-senders onderling over rolrelevante aspecten}

In het begin van dit hoofdstuk vroegen wij ons af of gezamenlijke rolonduidelijkheid misschien aan de hoofdverpleegkundigen zelf te wijten is, omdat zij falen in de perceptie van overigens duidelijke signalen.

Daarom gaan wij meningen van role-senders onderling vergelijken. Vinden wij tussen meningen van functionarissen veel verbanden dan zal er sprake zijn van een bepaald opinieklimaat dat met enige opmerkingsgave aanvoelbaar kan zijn.

In tabel 22 subtabell 1 bevinden zich de correlaties tussen meningen van role-senders over intermenselijke rolaspecten.

Bij de kolommeninspectie zien wij opnieuw de twee clusters, de eerste bestaande uit directe superieuren en specialisten en de tweede uit gediplomeerden en leerlingen. 
1. Role-senders onderling

$\begin{array}{llrrrrr} & \text { Spec. } & \text { Gedip. } & \text { Leerl. } & \text { Gedip. Leer. Leerl. } \\ \text { A. Verstandhouding } & .08 & .12 & .17 & -.02 & -.02 & .29+++ \\ \text { B. Spanningen } & .28++ & .14 & .11 & -.18+ & -.03 & .41++++ \\ \text { C. Verwachingen } & .32++t-.13 & -.15 & .11 & .22+ & .19+ \\ \text { D. Werkbooordeling } & .30+++ & .06 & .14 & -.04 & -.04 & .16\end{array}$

2. Hoofdverpleegkundigen over role-senders

$\begin{array}{lllcl} & \text { Sup. } & \text { Spec. } & \text { Gedip. } & \text { Leerl } \\ \text { A. Verstandhouding } & .26++ & .07 & .14 & .12 \\ \text { B. Spanningen } & .21+ & .09 & .16 & .02 \\ \text { C. Verwachtingen } & .20+ & .19+ & -.02 & .01 \\ \text { D. Werkbeoordeling } & .28+++.30+++ & .14 & .30+++\end{array}$

3. Role-senders over hoofdverpleegkundigen

$\begin{array}{lrrrr} & \text { Sup. } & \text { Spec. } & \text { Gedip. } & \text { Leerl } \\ \text { A. Verstandhouding } & -.06 & .04 & -.00 & -.07 \\ \text { B. Spanningem } & -.13 & -.09 & -.06 & -.11 \\ \text { C. Verwachtingen } & -.08 & -.15 & -.00 & -.22+ \\ \text { D. Werkbeoordeling } & .08 & .02 & .04 & -.30+++\end{array}$

1. Correlatie tussen meningen van role-senders over internnenselijke rol-aspecten.

2. Correlatie tussen ervaren rolonduidelijkheid van hoofdwerpleegkundigen (VOS $\perp t / m$ ) en hun mening over intermenselijke rol-aspecten.

3. Correlatie tussen ervaren rolonduidelijkheid van hoofdwerpleegkundigen en meningen van role-senders over intermenselijke rol-aspecten.

Verklaring van de afkortingen: Sup. = superieur; Gedip. = gediplomeerde; Leerd. = leerling.

Significant riveau: $t=.05 ;++=.01 ;+++=.005 ;+++++=.001$.

Tussen de clusters onderling is weinig of geen overeenstemming; van een duidelijk eensgezind opinieklimaat op de afdeling is dus geen sprake.

Bij de rij-inspectie zien we dat over de onderlinge verstandhouding met de hoofdverpleegkundigen alleen gediplomeerden en leerlingen eensluidende meningen hebben. Dit bevestigt de bevinding uit tabel 21 waaruit blijkt dat gediplomeerden en leerlingen met hoofdverpleegkundigen negatief significant van mening verschillen over hun onderlinge verstandhouding.

Over de onderlinge spanningen met hoofdwerpleegkundigen zien we meer correlaties; één daarvan is negatief, namelijk tussen medici en gediplomeerden. Dat betekent dus dat de specialisten en gediplomeerden het tegengestelde ervaren. Dit duidt opnieuw op een niet-eensgezind opinieklimaat.

De meeste overeenkomst vinden wij in de antwoorden op de vraag of hoofdverpleegkundigen aan de verwachtingen van role-senders kunnen voldoen. Superieuren/ specialisten, specialisten/leerlingen en gediplomeerden/leerlingen hebben een ongeveer eensluidende mening.

Op het gebied van duidelijkheid in werkbeoordeling blijken alleen directe superieuren en specialisten met elkaar overeenstemmende meningen te hebben. 
6.3 Correlaties tussen ervaren rolonduidelijkheid van hoofdverpleegkundigen en hun meningen over intermenselijke rol-aspecten

In tabel 22 subtabel 2 gaan we uit van de ervaren rol(on)duidelijkheid van hoofdverpleegkundigen ( VOS $1 \mathrm{t} / \mathrm{m}$ 6) en vragen ons af of de door hoofdverpleegkundigen ervaren rolrelevante aspecten inderdaad de ervaren rol(on)duidelijkheid beïnvloeden. Deze analyse gaat na of er correlaties aanwezig zijn tussen ervaren rol(on)duidelijkheid van hoofdverpleegkundigen en (volgens hoofdverpleegkundigen):

- slechte verstandhouding met role-senders;

- spanningen met role-senders;

- het niet kunnen voldoen aan verwachtingen van role-senders;

- het niet op de hoogte zijn van werkbeoordeling door role-senders.

Bij de kolominspectie blijkt dat hoofdverpleegkundigen, die rolonduidelijkheid ervaren, tevens rapporteren dat de vier bovengenoemde aspecten tussen hen en directe superieuren niet gunstig zijn.

Bij specialisten blijkt vooral het niet kunnen voldoen aan hun verwachtingen en onbekendheid met werkbeoordeling een relatie te hebben met ervaren rolonduidelijkheid van hoofdverpleegkundigen.

Bij gediplomeerden treffen wijgeen enkele correlatie aan. Bij leerlingen correleert het niet op de hoogte zijn van de werkbeoordeling met de erva ren rolonduidelijkheid van hoofdverpleegkundigen.

Bij de rij-inspectie zien we de meeste correlaties tussen ervaren rolonduidelijkheid van hoofdverpleegkundigen en het niet op de hoogte zijn van de werkbeoordeling door role-senders.

In tabel 21 zagen wij tevens dat hier de grootste gezamenlijke rolonduidelijkheid voor hoofdverpleegkundigen ligt. Ervaren en gezamenlijke rolonduidelijkheid blijken dus beter met elkaar in overeenstemming dan ervaren rolonduidelijkheid en gezamenlijke taakonduidelijkheid.

6.4 Correlaties tussen ervaren rolonduidelijkheid van hoofdverpleegkundigen en meningen van role-senders over intermenselijke rol-aspecten

In deze analyse gaan wij eveneens uit van de ervaren rolonduidelijkheid van hoofdverpleegkundigen (VOS $1 \mathrm{t} / \mathrm{m}$ 6) maar nu vragen we ons af wat de role-senders zelf antwoorden op de vragen die in dit hoofdstuk centraal staan. Als hoofdverpleegkundigen zeggen rolonduidelijkheid te ervaren, geven dan de role-senders aan dat rolrelevante aspecten tussen hen en hoofdverpleegkundigen minder gunstig zijn?

Bij de kolom-inspectie zien we dat dit niet het geval is. De negatieve correlaties wijzen zelfs in de tegengestelde richting.

Opvallend zijn de negatieve correlaties bij leerling-verpleegkundigen, waarvan twee significant zijn. Dit betekent dat als hoofdverpleegkundigen spreken over ervaren rolonduidelijkheid, leerlingen juist van mening zijn dat zij hoofdverpleegkundi- 
gen goed informeren over hun werkbeoordeling en dat hoofdverpleegkundigen juist gemakkelijk aan hun verwachtingen kunnen voldoen. Een vergelijking tussen de subtabellen 2 en 3 van tabel 22 levert de informatie dat positieve relaties in negatieve kunnen veranderen. Hoe is dat te verklaren?

In subtabel 2 is steeds dezelfde groep aan het woord: die van de hoofdverpleegkundigen. In de persoonlijke beleving van hoofdverpleegkundigen zal een zekere mate van overeenkomst te vinden zijn tussen de door hen als minder gunstig ervaren rolrelevante aspecten en hun ervaren rolonduidelijkheid. Dit is in overeenstemming met de roltheorie die zegt dat stress verband houdt met gepercipieerde bedreigingen.

In tabel 22 subtabel 3 zijn role-senders aan het woord. Wij gaan daar na hoe de meningen van role-senders - vier afzonderlijke groepen respondenten - passen in de ervaren rol(on)duidelijkheid van hoofdverpleegkundigen. Hier is dus sprake van percepties van verschillende groepen.

De afwezigheid vam correlaties is in dit verband niet in tegenspraak met de roltheorie.

\subsection{Samenvatting}

In dit hoofdstuk werden enkele kernaspecten van het rolbegrip in het onderzoek betrokken. Wij gingen na of hoofdverpleegkundigen en role-senders hierover dezelfde ervaring hadden (gezamenlijke rolduidelijkheid) of dat hun meningen significant van elkaar verschillen (gezamenlijke rolonduidelijkheid).

Uit de eerste analyse blijkt dat gezamenlijke rolonduidelijkheid vooral wordt aangetroffen in het element onbekendheid met de werkbeoordeling door role-senders. Dit stemt overeen met onze visie op de afwezigheid wan een relatie tussen ervaren rolonduidelijkheid en gezamenlijke taakonduidelijkheid. (hoofdstuk 5, blz. 112). Het eens zijn over het "wat" betekent nog niet het eens zijn over het "hoe". Dat een eensluidende mening hierover vaak afwezig is, wordt duidelijk uit deze aanvullende analyse.

Ook blijkt er gezamenlijke rolonduidelijkheid te bestaan tussen zowel hoofdverpleegkundigen en directe superieuren, alsook tussen hoofdverpleegkundigen en specialisten over hun onderlinge spanningen. Hoofdverpleegkundigen onderschatten hun spanningen met directe superieuren en overschatten de spanningen met specialisten (gezien vanuit het standpunt van role-senders).

Gezamenlijke rolonduidelijkheid tussen enerzijds hoofdverpleegkundigen en anderzijds gediplomeerden en leerlingen treffen wij aan als de onderlinge verstandhouding ter sprake komt. Hoofdverpleegkundigen overschatten namelijk hun verstandhouding met gediplomeerden en leerlingen (volgens het standpunt van genoemde role-senders).

$\mathrm{Bij}$ het analyseren van de gezamenlijke rolonduidelijkheid onderseheiden wij twee clusters rondom de hoofdverpleegkundigen. De eerste wordt gevormd door directe superieuren en specialisten samen, de tweede door gediplomeerden en leerling-ver- 
pleegkundigen. Deze twee clusters zien wij opnieuw bij het berekenen van correlaties tussen meningen van role-senders.

Directe superieuren en specialisten zijn het in veel gevallen met elkaar eens, evenals gediplomeerden en leerling-verpleegkundigen. De overige (vaak negatieve) correlaties zijn van dien aard dat wij niet zozeer van een onderlinge eensgezindheid kunnen spreken. Een duidelijk algemeen opinieklimaat is niet aanwezig. Gezamenlijke rolonduidelnjkheid van hoofdverpleegkundigen kunnen wij dus niet primair toeschrijven aan het falen van hun perceptie.

Vervolgens gaan wij na of er correlaties aanwezig zijn tussen ervaren rolonduidelijkheid van hoofdverpleegkundigen en het door hen als minder gunstig ervaren rolrelevant gedrag van role-senders. Uit de analyse blijkt dat percepties van hoofdverpleegkundigen over het door hen als minder gunstig ervaren rolrelevant gedrag van rol-senders, in overeenstemming zijn met hun ervaren rolonduidelijkheid. Dit bevestigt de rol-theoretische uitspraak dat stress (c.q. rolonduidelijkheid) verband houdt met gepercipieerde bedreiging.

Uit de laatste analyse blijkt dat de mening van role-senders over hun rolrelevant gedrag niet correleert met de daarmede verband houdende ervaring van hoofdverpleegkundigen.

Uit de tabel spreekt een zekere mate van onbegrip tussen hoofdverpleegkundigen en role-senders. Opvallend zijn in dit verband de bevindingen tussen hoofdverpleegkundigen en leerlingen. Bij ervaren rolonduidelijkheid van hoofdverpleegkundigen zijn leerlingen juist van mening dat zij hoofdverpleegkundigen goed op de hoogte houden van hun werkbeoordeling en dat hoofdverpleegkundigen juist gemakkelijk aan hun verwachtingen kunnen beantwoorden. 


\section{Hoofdstuk 7}

\section{Ervaren rolonduidelijkheid, institutionele context en werkaspecten}

Sommige auteurs zijn van mening dat men in grote ziekenhuizen het technische aspect belangrijker vindt dan de mensgerichte benadering. Dat zou, volgens hen, een van de oorzaken kunnen zijn van rolonduidelijkheid van hoofdverpleegkundigen, die immers meestal een voorkeur hebben voor de persoonsgerichte benadering. De technische gerichtheid komt, aldus sommige auteurs, meer voor op chirurgische dan op interne afdelingen. Enkelen menen dat in grote steden het maatschappelijk leven een humane patiëntenzorg bemoeilijkt.

Wij willen daarom nagaan of er in dit onderzoek verbanden a anwijsbaar zijn tussen enerzijds ervaren rolonduidelijkheid van hoofdverpleegkundigen en anderzijds ziekenhuisgrootte, type afdeling en regio en verder willen we bekijken welke verbanden er zijn tussen ervaren rolonduidelijkheid en andere stressoren en strains.

Tussen de institutionele context - ziekenhuisgrootte, type afdeling en regio - en de ervaren rol(on)duidelnjkheid van hoofdverpleegkundigen blijkt geen enkel significant verband te bestaan, zie bijlage 6 tabel 39 .

\subsection{Correlaties tussen ervaren rol(on)duidelijkheid met stressoren en strains}

Wij berekenden de correlaties tussen ervaren rol(on)duidelijkheid van hoofdverpleegkundigen en de overige variabelen van het model die in de VOS-lijst voorkomen.

Daar het onderzoeksmodel werkt met begrippen stressoren (druk van buitenaf) en strains (spanningen die het individu ervaart), delen wij de onderzoeksbevindingen hier ook zo in.

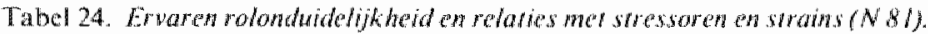

\begin{tabular}{|c|c|c|c|c|c|}
\hline Stressoren & r & sign. & Strains & $\mathbb{l}^{\prime}$ & sign. \\
\hline Verantw. voor anderen & -.29 & .005 & Arbeidsontevredenheid & .12 & - \\
\hline Werkoverbelasting & .14 & - & Gerondheidsklachien & 27 & .01 \\
\hline Niet gebruik kennis & .40 & .001 & Psychische klachten & .40 & .001 \\
\hline Participatiegebrek & .17 & - & Verlics zelfwaardering & .42 & .001 \\
\hline Rolconflict & .21 & .05 & Bezorgdh. functioneren & .45 & .001 \\
\hline Gebrek support chel & 35 & .001 & Ziekleverzuing &.--13 & - \\
\hline Gebrek suppori collegi & .25 & .01 & & & \\
\hline Gebrek support anderen & .18 & - & Zoeken andere batan & .08 & - \\
\hline Giebrek suppon verwanten & .18 & $=$ & Eerder met pensioen & .12 & - \\
\hline Toekomstonzekerheid & 29 & .001 & & & \\
\hline
\end{tabular}


1. Rolond

2. Verant.

3. Werkbel.

4. Kennis

5. Bestuiny.

6. Rolcon.

7. Socsup.

\$. Socol.

9. Socand.

10. Socpart.

III. Socwerw.

12. Toekonst

13. Arbsat.

14. Gezondh

35. Psych

16. Zelta

17. Bezorgdh.

18. Princip

19. Persinst

20. Veraum

21. Leeftijd

22. Geslach

23. Burger st.

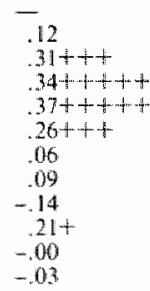

$-07$

$.12 \quad .38+4+4+$

$.10 .07 \quad .12$

$.09 \quad .30+t+$

$-.07$

$.02 .26+$

$-.00 \quad .21+$

$-.00 \quad .24+$

$-11-100$

$.00 \quad .04$

$.584+4$
-.16
$.24-1$
.02
-.02
.17
-.204

$\begin{array}{ll}-.33+5++ & - \\ -.13 & -.08 \\ -.14 & .32 \\ -.18 & -.08 \\ .31+t+t & -.07 \\ -.14 & -.11 \\ .18 & -.10\end{array}$

$32+4+4+4+4++4+$

$08+12+11+4+4+16=$

$.24+\quad .06-.04-$

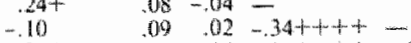

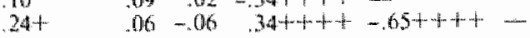

zowel rolonduidelijkheid ervaren als het gevoel krijgen onvoldoende met hun kennis en bekwaamheden te kunnen werken.

Er is ook een andere verklaring mogelijk. Als hoofdverpleegkundigen niet goed weten wat anderen van hen verwachten en hoe zij worden beoordeeld, zullen zij zich minder actief gedragen en zullen ze minder initiatieven ontplooien.

Geen deelname besluitvorming

In hoofdstuk 5 is gebleken dat rolonduidelijkheid meer structureel verankerd is. Ad hoc beslissingen over concrete taken/contacten zullen daarom weinig invloed uitoefenen op ervaren rolonduidelijkheid van hoofdverpleegkundigen.

\section{Rolconflict}

Voor verklaring van de relatie tussen rolonduidelijkheid en rolconflict noemen we twee mogelijke interpretaties. Wanneer anderen op het werk tegenstrijdige verwachtingen hebben en opdrachten geven (rolconflict) zal de hoofdverpleegkundige niet weten wat zij moet doen (rolonduidelijk).

Een andere mogelijkheid is dat de hoofdverpleegkundigen de conflicterende verwachtingen wel goed begrijpen en kunnen plaatsen - bijvoorbeeld vanuit verschillende behandelingsplannen - (rolduidelijkheid), maar dat zij niet weten welke prioriteiten zij zullen stellen. 
De chef, als krachtige role-sender, is een belangrijke persoon voor de rolduidelijkheid van hoofdverpleegkundigen. Wanneer de communicatie tussen hem en het afdelingshoofd onvoldoende is en wanneer de hoofdverpleegk undige weinig sociale ondersteuning van hem ervaart, zal zij onvoldoende van zijn verwachtingen op de hoogte geraken en rolonduidelijkheid ervaren.

\section{Gebrek support collega's}

Collega's wormen een belangrijk referentiekader voor hoofdverpleegkundigen. Role-taking en role-making vindt plaats in interactie met belangrijke anderen. $\mathrm{Bij}$ ontstentenis van sociale ondersteuning kan dit proces stagneren en rolonduidelijkheid veroorzaken.

\section{Gebrek support verwanten}

Als hoofdverpleegkundigen hun werkervaringen kunnen doorspreken met diegenen die hen vertrouwd zijn, kan dat bijdragen tot een beter begrip voor gerezen problemen en kan dat rolonduidelijkheid afzwakken of voorkomen.

\section{Toekomstonzekerheid}

Wanneer hoofdverpleegkundigen over de huidige rol en positie onzeker zijn, zijn zij dat waarschijnlijk ook over de toekomstige loopbaanmogelijkheden en hebben zij daarvan een onduidelijke voorstelling.

\section{Strains}

\section{Arbeidsontevredenheid}

Er blijkt geen significant verband te bestaan tussen ervaren rolonduidelijkheid en arbeidsontevredenheid. Het is niet mogelijk dit te verklaren met wat Kahn(1964)"de sterke zelfzender" noemt (zie hoofdstuk 3) die geen behoefte heeft aan duidelijke rolverwachtingen van anderen. In hoofdstuk 5 zagen wij namelijk dat hoofdverpleegkundigen méér rolduidelijkheid wensen.

\section{Gezondheidsklachten en psychische klachten}

Spanningen in het werk kunnen aanleiding geven tot lichamelijke en psychische a andoeningen. Verschillende onderzoekers hebben dit reeds aangetoond (Reiche 1982, Van Bastelaer en Van Beers 1982). Ook in ons onderzoek blijkt een verband aanwezig tussen ervaren rolonduidelijkheid en psychische en lichamelijke klachten.

\section{Bezorgdheid om eigen functioneren}

Rolonduidelijkheid maakt een functionaris kwetsbaar. Wanneer doet hij het in de ogen van anderen wêl en wanneer niét goed? Als role-taking problematisch wordt wanneer hoofdverpleegkundigen niet duidelijk zien welke rol zij dienen te vervullen, dan zal ook de role-making (het functioneren) stroef verlopen. Vanuit deze visie is het verband tussen rolonduidelijkheid en een bezorgdheid over het eigen functioneren goed werk laarbaar. 
Verlies van zelfwaardering

Als role-taking en role-making niet soepel veriopen en de functionaris zich zorgen maakt over het oordeel van anderen, zal dit zijn zelfachting en zelfrespect kunnen aantasten.

Uit onderzoek bij middenkaderleden en personeelsfunctionarissen blijkt er een verband te bestaan tussen rolonduidelijkheid en het afnemen van zelfachting. Ook in ons onderzoek vonden wij een relatie tussen rolonduidelijkheid van hoofdverpleegkundigen en een verlies van zelf waardering.

\section{Ziekleverzuim}

De negatieve correlatie tussen rolonduidelijkheid en ziekteverzuim betekent dat met het toenemen van de rolonduidelijkheid het ziekteverzuim afneemt. Een verklaring hiervan kan liggen in het feit dat wij de respondenten zélf ernaar vroegen. Zoverkregen gegevens over verzuim blijken soms niet zo betrouwbaar te zijn als de verzuimcijfers afkomstig van de organisatie.

\section{Zoeken van een andere baan of vervroegd pensioen}

In de literatuur wordt gewezen op het verband tussen rolonduidelijkheiden verloop. Wij gingen na of er relaties bestaan tussen rolonduidelijkheid van hoofdverpleegkundigen en hun intentie van baan te veranderen of eerder met pensioen te gaan. Op deze vragen ontvingen wij de volgende antwoorden:

"Als u vrij zou kunnen kiezen tussen het blijven in deze functie en een andere functie, wat zou u dan doen?"

Blijven $\quad 78 \%$

Vertrekken $21 \%$

"'Denkt u tot uw 60e jaar uw functie uit te oefenen?"

$\begin{array}{ll}\text { Neen } & 48 \% \\ \text { Weet nog niet } & 22 \% \\ \mathrm{Ja} & 30 \%\end{array}$

Bovenstaande antwoorden brachten wij in verband met ervaren rolonduidelijkheid. Er blijkt geen significante relatie te bestaan tussen ervaren rolonduidelijkheid van hoofdverpleegkundigen en hun wens een andere baan te zoeken of eerder dan gebruikelijk met pensioen te gaan.

\subsection{Samenvatting en discussie}

Uit het onderzoek blijkt dat de institutionele context, te weten ziekenhuisgrootte, type afdeling en regio, geen verband houdt met ervaren rol(on)duidelijkheid van hoofdverpleegkundigen.

Rolonduidelijkheid blijkt relaties te hebben met negatieve aspecten in de werksituatie en met lichamelijke en psychische klachten.

Verschillende verbanden laten zich gemakkelijk interpreteren, zoals de correlaties 
tussen enerzijds ervaren rolonduidelijkheid en anderzijds het dragen van mincler verantwoordelijkheid voor anderen, niet gebruik kunnen maken van kennis en vaardigkeden, rolconflict, toekomstonzekerheid, gebrek aan socialle support in werk en familiekring, klachten over gezondheid en psychische conditie, bezorgdheid om eigen functioneren en verlies van zelfwaardering.

De afwezigheid van een significante correlatie tussen ervaren rolondu idelijkheid en arbeidsontevredenheid is niet zo opmerkelijk. Uit de literatuurstudie weten wij namelijk dat dit verband in sommige onderzoeken wel en in andere weer niet wordt aangetroffen.

Er is geen significante correlatie aanwezig tussen ervaren rolonduidelijkheid van hoofdverpleegkundigen en hun mening dat zij geen of weinig inspraak hebben in de besl uitvorming. Dit is een punt van overweging voor de ziekenhuisleiding, die meent rolonduidelijkheid van hoofdverpleegkundigen te kunnen verhelpen door louter veelwuldig vergaderen.

Dat intentie om te vertrekken geen verband houdt met rolonduidelijkheid kan zowel positief als negatief worden aangeduid. Positief is, dat voor een goed arbeidsklimaat een zekere stabiliteit in de leiding gunstig is. Maar het is een negatief punt dat hoofdverpleegkundigen met rolonduidelijkheid blijven functioneren en mét de toename van rolambiguiteit psychische klachten ervaren ( $r$.40 sign. 001). Ligt hierineen oorzaak voor de soms als ongunstig ervaren arbeidsomstandigheden? 


\section{Hoofdstuk 8}

\section{Rigiditeit van hoofdverpleegkundigen en relaties met ervaren rolonduidelijkheid}

In hoofdstuk 3 en 4 presenteerden wij het onderzoeksmodel dat als leidraad kan dienen bij het onderzoek naar relaties van ervaren rolonduidelijkheid met arbeidsomstandigheden, welzijn en gezondheid.

Tot nu toe bespraken wij vier blokken variabelen: de objectieve werkomgeving in hoofdstuk 5, de eigen beleving van de hoofdverpleegkundige in hoofdstuk $6 \mathrm{en} 7 \mathrm{en}$ de reacties op stressoren en strains in hoofdstuk 7 .

Behalve deze vier onderdelen, namen Caplan et al. (1975) nogandere elementen op in het model: "persoon" en "sociale ondersteuning". Deze beide variabelen hebben zowel een direct effect op strains alsook een conditionerend effect op de relatie stressoren/strains. Het model veronderstelt bij verschillen in persoonlijkheidskenmerken en sociale ondersteuning ook verschillende relaties tussen stressoren en strains. In hoofdstuk 9 komt de socialle ondersteuning aan bod.

In dit hoofdstuk analyseren wij de persoonlijkheidskenmerken.

Wij selecteerden voor deze analyse het persoonlijkheidskenmerk rigiditeit/flexibiliteit. Daarvoor hebben we de volgende reden. Uit onderzoeksbevindingen (Reiche 1982) blijkt dat er een verband bestaat tussen rigiditeit en rolduidelijkheid. Geldt dat ook voor onze populatie?

Uit de literatuurstudie zijn we te weten gekomen dat leiderschapsgedrag-autoritair/ niet autoritair - het werkklimaat op de afdeling kan beinnvloeden. Heeft de autoritaime (rigide) hoofdverpleegkundige méér negatieve reacties op ervar ren rolonduidelijkheid dan de flexibele afdelingshoofden?

Wij gaan verder na of leeftijd, geslacht of burgerlijke staat in verband blijken te staan met ervaren rol(on)duidelijkheid van hoofdverpleegkundigen.

\subsection{Rigiditeit en flexibiliteit}

Caplan et al. (1975) zeggen dat het begrip persoon betrekking heeft op alle min of meer blijvende lichamelijke en psychologische kenmerken van de mens, die leiden tot een voor het individu kenmerkend patroon van gedragingen binnen de sociale en culturele context.

Rigiditeit/flexibiliteit omschrijft Rubenowitz (1963) als volgt: "In adults, a general factor of flexibility/rigidity can be identified, a factor which accounts for a considerable part of the variance in thinking, attitudes and displayed behavior." Tellegen (1968) ziet rigiditeit alls een beperking van de gedragsalternatieven. Een rigide mens maakt tijdsindelingen en schema's en wil zaken en dingen op een vaste 
plaats. Caplan (1971) zou het begrip flexibiliteit/rigiditeit liever vervangen door "tolerance/intolerance for uncertainty" omdat volgens hem het karakteristieke van flexibiliteit is de bereidheid om onzekerheid, desorganisatie en onderbreking te accepteren. Volgens Rubenowitz vertonen rigide mensen in vergelijking met flexibele de volgende verschillen: meer weerstand om plannen en opvattingen te veranderen, meer angst en vrees en een meer negatieve kijk op het leven, meer autoritair gedrag en meer bekommernis om hun prestige, meer intolerantie en vooroordelen, een beperktere belangstelling en minder algemene kennis, een concretere instelling en een hogere leeftijd.

Kahn et al. (1964) omschrijven rigide personen in ongeveer gelijke termen als Rubenowitz.

De behoefte aan waardering en de aanwezigheid van sociale angst zijn, aldus Tellegen de oorzaken van de hang naar orde, regelmaat en de vastomlijnde gedragingen die voor een rigide mens karakteristiek zijn. Hij vreest veranderingen. De rigide mens heeft een gestoorde communicatie met de buitenwereld, die hij terugbrengt tot vastomlijnde begrippen.

In het volgende onderzoeksmodel worden de veronderstelde effecten van rigiditeit/ flexibiliteit aangegeven.

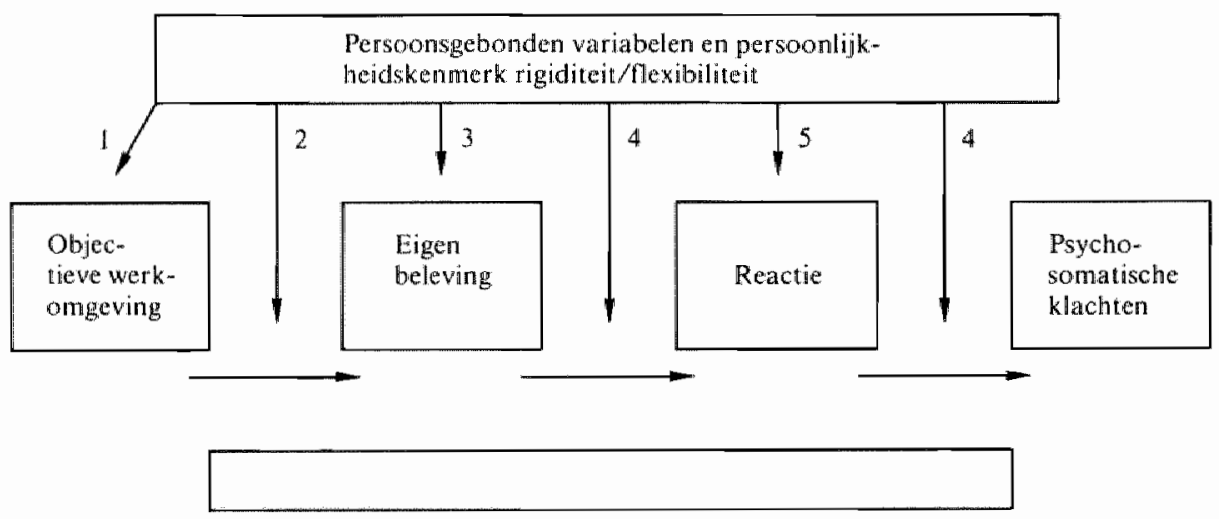

Figum \&. Het ISR-model.

Meting

Rigiditeit/flexibiliteit van hoofdverpleegkundigen werd gemeten door VOS-vragen $54 \mathrm{t} / \mathrm{m} 63$. Vóór de analyse werden de scores omgedraaid. Een hoog getal wijst nu op rigiditeit, een laag getal op flexibiliteit.

Op grond van die scores onderscheiden wij in ons onderzoek flexibele afdelingshoofden (N 38) en rigide afdelingshoofden ( $N 37$ ).

Relatie tussen rigiditeit/flexibiliteit en objectieve omgeving (figuur 8, pijl 1)

Rigide functionarissen hebben aldus Kahn et al. (1964) voorkeur voor stabiele, gestructureerde omgevingen. Zij vragen duidelijk omschreven taken en voelen zich 
aangetrokken tot vertrouwde werkgewoonten. De flexibelen voelen zich daarentegen aangetrokken tot werkzaamheden met veel afwisseling, veelsoortige ervaringen, weinig routinematige arbeid, goede collegiale verhoudingen en veel contacten met anderen.

Deze verschillende persoonlijkheidstypen zullen zich dus tot bepaalde werkomgevingen voelen aangetrokken. Omgekeerd oefent de werkomgeving ook invloed uit op de functionaris. Merton (1957) bijwoorbeeld wijst erop dat de sociale structuur van de bureaucratie het individu dwingt tot methodisch, voorzichtig en gedisciplineerd werken.

\section{Copingstrategieën (figuur 8 pijl 1 en 3 )}

Rigide en flexibele mensen hanteren verschillende copingtechnieken. Kahn et al. (1964) omschrijft dieals volgt: Als rigide mensen storende invloeden vanuit de sociale omgeving ervaren zijn zij geneigd zich af te keren van degenen die hen veroorzaken. Zij stellen zich tegenover gezagsdragers afhankelijker op dan flexibele mensen gewoonlijk doen. $\mathrm{Zij}$ conformeren zich meer aan de regels. Bij toenemende stress neigen rigide types tot dwangmatige werkgewoonten. Zij maken in grotere mate gebruik van copingmechanismen als ontkenning en projectie dan flexibelen. Rigide functionarissen hebben een lagere tolerantie voor werkbelasting en onduidelijkheid dan flexibelen.

Flexibelen daarentegen staan - in vergelijking met rigiden - meer open voor de invloed van anderen. Het gevolg hiervan is een gevoeligheid voor rolconflicten. Ze zijn optimistisch en zien vaak hun eigen beperkingen niet. Dit kan ertoe leiden dat een te groot beslag op hun tijd wordt gelegd. Ze vertonen een grote mate van teamoriëntatie.

De stressoren waarmede flexibele functionarissen vermoedelijk worden geconfronteerd zijn derhalve rolconflicten en kwantitatieve werkbelasting. Voor rolconflicten hebben zij waarschijnlijk een lage tolerantie, tegen veel werk zien zij niet op.

Uit verschillende onderzoeksbevindingen komt echter naar voren dat rigiden minder rolonduidelijkheid erwaren. Reiche (1982) meent dat bepaalde copingmechanismen van rigiden, zoals het veel zoeken van geruststellende contacten en informatie die hun mening bevestigt, erop gericht zijn rolonduidelijkheid te voorkomen of te beperken.

Rigiditeit/flexibiliteit als conditionerende/interveniërende variabele (figuur 8 , pijl 2 en 4)

Wij zochten naar inzicht in de interactie van rigiditeit/flexibiliteit ten opzichte van de relaties tussen stressoren en strains. Met behulp van twee of meer extreme groepen kan het conditionerende effect van rigiditeit/flexibiliteit worden gemeten. Het aantal studies op dit terrein is beperkt. Cassee en Philipsen (1968) bestudeerden de conditionerende werking van de autoritaire instelling op de perceptie van het leiderschap. Zij vroegen aan 158 (hoofd)verpleegkundigen hoe hun directe chef in het ziekenhuis leiding geeft. De vragenlijst bevatte een door Weima voor Nederland 
bewerkte versie van de F-schaal. Verpleegkundigen met een meer autoritaire instelling blijken hun chef te zien als een meer instrumenteel leider dan verpleegkundigen met een lage F-score.

Relatie iussen rigiditeit/flexibiliteit en strains (figuur 8, pijl 5)

Daar wij ons in dit onderzoek beperken tot ervaren rol(on)duidelijkheid, die een stressor is, komt pijl 5 in dit verband niet voor bestudering in aanmerking.

\section{Onderzoekswraagstellingen}

In dit hoofdstuk willen wij de wolgende vragen beantwoorden:

- Hebben rigide hoofdverpleegkundigen méér gezamenlijke taakduidelijkheid dan flexibele hoofdverpleegkundigen (pijl 1)?

- Wat zijn de conditionerende effecten van rigiditeit/flexibiliteit op de relatie tussen gezamenlijke taak(on)duidelijkheid en ervaren rol(on)duidelijkheid (pijt 2)?

- Is er een relatie tussen rigiditeit/flexibiliteit van hoofdverpleegkundigen en hun ervaren rol(on)duidelijkheid (pijl 3)?

- Welke conditionerende effecten heeft rigiditeit/flexibiliteit van hoofdverplleegkundigen op de relaties tussen ervaren rolonduidelijk heid en andere stressoren en strains (pijl 4)?

- Houden leeftijd, geslacht en burgerlijke staat verband met ervaren rolonduidelijkheid van hoofdverpleegkundigen (pijl 3)?

\subsection{Gezamenlijke taak(on)duidelijkheid en rigiditeit/flexibiliteit}

In hoofdstuk 5 berekenden wij de gemiddelden van de gezamenlijke taak(on)duidelijkheid tussen alle hoofdverpleegkundigen samen en hun role-senders. Thans gaan wij bij de hoofdverpleegkundigen na of de rigide afdelingshoofden meer gezamenlijke tarkduidelijkheid hebben dan de flexibele. Met behulp van de t-test willen wij nagaan of de gevonden verschillen significant zijn.

Zie bijlage 8 tabel 42 .

De verschillen tussen de gezamenlijke taak(on)duidelijkheid blijken niet groot te zijn. Er is sprake van middelmatige taakduidelijkheid, zowel voor alle hoofdverpleegkundigen samen alsook voor de rigide en flexibele afdelingshoofden afzonderlijk. (voor omschrijving van middelmatige taakduidelijkheid: zie hoofdstuk 5).

De gevonden verschillen zijn niet significant.

Hoewel de verschillen niet groot zijn, blijkt - tegen de verwachting in - bij de taken dat tlexibele afdelingshoofden méér gezamenlijke duidelijkheid kennen dan hun rigide collega's. Bij contacten daarentegen zien wij dat de gezamenlijke taakduidelijkheid bij rigide hoofdverpleegkundigen groter is dan bij flexibele afdelingshoofden. De verschillen zijn echter zo klein dat wij daar geen waarde aan mogen hechten. 
8.3 Conditionerende effecten van rigiditeit/flexibiliteit op de relatie tussen gezamenlijke taak(on)duidelijkheid en ervaren rol(on)duidelijkheid.

Hoewel bij rigide en flexibele hoofdverpleegkundigen de verschillen tussen gezamenlijke taak(on)duidelijkheid niet groot zijn, is het mogelijk dat rigide hoofdverpleegkundigen door bepaalde copingmechanismen tóch meer rolduidelijkheid ervaren dan hun flexibele collega's. Daarom gaan wij na of er verschillen in correlaties bestaan tussen gezamenlijke taak(on)duidelijkheid en ervaren rol(on)iduidelijkheid bij rigide en bij flexibele hoofdverpleegkundigen.

De scores van de variabelen lopen niet in dezelfde richting.

Gezamenlijke taakonduidelijkheid/duidelijkheid schoort 0 - 5 en ervaren rolonduidelijkheid/duidelijkheid $15-0$.

Gezien de score-verloop verwachten wij een negatieve correlatie tussen beide variabelen.

Eerst gaan wij na of er significante correlaties aanwezigzijn bij deze beide variabelen. Vervolgens of deze correlaties significant van elkaar verschillen, bij vergelijking van de groep rigide met de groep flexibele hoofdverpleegkundigen. Dit laatste gebeurt door middel van de Z-toets:

$$
\mathrm{Z}=\frac{\mathrm{Z}_{1}-\mathrm{Z}_{2}}{\sigma \mathrm{Z}_{1} \mathrm{Z}_{2}} \sigma \mathrm{z}_{1} \mathrm{Z}_{2}=\sqrt{\frac{1}{\mathrm{~N}_{1}-3}+\frac{2}{\mathrm{~N}_{2}-3}}
$$

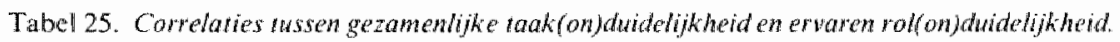

Taken

\begin{tabular}{|c|c|c|c|c|c|c|}
\hline $\begin{array}{l}\text { Hoofdwerpl.-superieur } \\
\text { Hoofdwerpl.-special ist } \\
\text { Hoofdwerpl.-gediplon. } \\
\text { Hoofdverpl.-leerling }\end{array}$ & $\begin{array}{r}-.00 \\
.02 \\
.12 \\
.29\end{array}$ & .005 & $\begin{array}{r}-.15 \\
-.00 \\
.16 \\
.12\end{array}$ & $\begin{array}{r}-.04 \\
-.21 \\
-.20 \\
-.11\end{array}$ & & $\begin{array}{r}.462 \\
-.887 \\
-.175 \\
.045\end{array}$ \\
\hline Role-sett & .22 & & .05 & -.07 & & -.083 \\
\hline $\begin{array}{l}\text { Contacten } \\
\text { Hoofdwerpl.-superieur } \\
\text { Hoofdverpl.-specialist } \\
\text { Hoofdverpl.-gediptom. } \\
\text { Hoofdverpl.-leerling }\end{array}$ & $\begin{array}{r}-.26 \\
-.01 \\
-16 \\
-17\end{array}$ & .05 & $\begin{array}{r}.07 \\
-.09 \\
.09 \\
.05\end{array}$ & $\begin{array}{r}-.32 \\
.18 \\
.10 \\
-.11\end{array}$ & .05 & $\begin{array}{r}1.09 \\
-.383 \\
-.042 \\
-.250\end{array}$ \\
\hline Rolc-set & -.11 & & -.07 & -.02 & & .208 \\
\hline
\end{tabular}

\begin{tabular}{llll}
\multicolumn{1}{c}{ II } & \multicolumn{1}{c}{ III } & \multicolumn{1}{c}{ IV } \\
Alle hvpl. & Rigide & Flexibele & Z-waarde \\
& hvpl. & hvpl. & sign, verschil \\
$(\mathrm{N}=81)$ & $(\mathrm{N}=37)$ & $(\mathrm{N}=38)$ & II en III \\
$\mathrm{r}$ sign. & r sign. & $r^{\prime}$ sign. &
\end{tabular}


De meeste correlaties in tabel 25 lopen in de verwachte richting, in acht gevallen gebeurt dat echter niet. Daarwan zijn er viff terug te winden bij gediplomeerden en leerlingen. Dat betekent dat als de hoofdverpleegkundigen spreken van ervaren rolonduidelijkheid, er tussen hoofdverpleegkundigen/gediplomeerden en hoofdverpleegkundigen/leerlingen juist sprake is van gezamenlijke taakduidelijkheid. Dit zien we vooral bij rigide afdelingshoofden.

Slechts één correlatie is significant. Dat betekent dat gezamenlijke taakduidelijkheid (contacten) tussen flexibele afdelingshoofden en hun directe superieuren een significante relatie heeft met ervaren rolduidelijkheid van hoofdverpleegkundigen. Tussen de correlaties is echter geen enkel significant verschil. Dat betekent dat rigide en flexibele hoofdverpleegkundigen niet significant van elkaar verschillen als het gaat om het verband tussen gezamenlijke taakduidelijkheid en ervaren rolduidelijkheid.

Evenals in hoofdstuk 5 moeten wij ook hier constateren dat onderlinge eenstemmigheid over de vijf belangrijkste taken/contacten, zoals wij die waarnemen bij rigide/flexibele focal persons, bij hen niet uitmonden in meer ervaren rolduidelijkheid. Eenstemmigheid over "wat" (gezamenlijke taakduidelijkheid) betekent nog niet een bekendheid met het "hoe" (ervaren rolduidelijkheid).

\subsection{Relatie tussen rigiditeit/flexibiliteit en ervaren rol(on)duidelijkheid}

De scores van de variabelen rigiditeit/flexibiliteit en ervaren rolonduidelijkheid/ duidelijkheid lopen in dezelfde richting. Een hoog getal wijst op zowel rigiditeit als op ervaren rolonduidelijkheid. Wij verwachten een correlatie tussen rigiditeit en rolduidelijkheid, dus een negatief verband.

Uit dle correlatiematrix blijkt dat rigiditeit van hoofdverpleegkundigen inderdaad negatief samenhangt met rolonduidelijk keid, $\mathrm{r}-.28$ sign. .005. Dus rigide afdelingshoofden ervaren meer rolduidelijkheid dan hun flexibele collega's.

Bestaan er significante verschillen tussen rigide en flexibele hoofdverpleegkundigen met betrekking tot hun reacties op rolonduidelijkheid?

Uit tabel 26 blijkt weer dat flexibele hoofdverpleegkundigen significant meer rolonduidelijkheid ervaren dan rigide afdelingshoofden. Maar in hun reacties op de ervaren rol(on)duidelijkheid bespeuren wij geen significante verschillen.

8.5 Conditionerende effecten van rigiditeit/flexibiliteit op de relaties tussen ervaren rol(on)duidelijkheid en enkele stressoren en strains

In hoofdstuk 7 zagen wij hoe hoofdverpleegkundigen reageren op ervaren rolonduidelijkheid.

Worden deze reacties bij rigiditeit/flexibiliteit versterkt of verzwakt? 


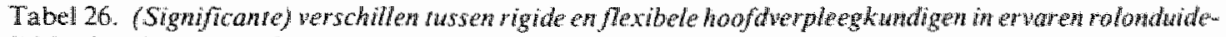
hikheiden de reacries darap.

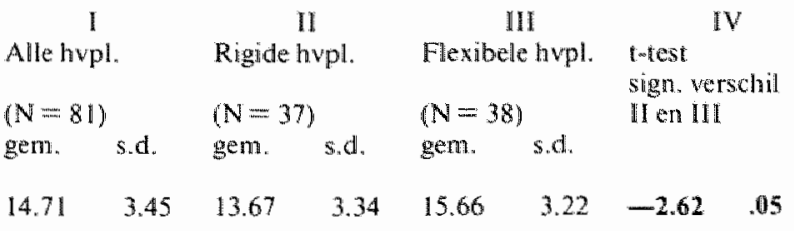

\section{Stressoren}

Verantwoordelijkheid

woor anderen

Niet gebruik kunnen

maken van kennis

Rolconflict

Toekomstonzekerheid

$\begin{array}{rrrrrrr}14.84 & 2.41 & 15.54 & 1.80 & 14.60 & 2.19 & 2 .- \\ 7.12 & 2.44 & 6.89 & 2.39 & 7.37 & 2.42 & -.86 \\ 5.25 & 2.04 & 5.28 & 2.16 & 5.32 & 1.86 & .08 \\ 10.07 & 3 .- & 10.03 & 3.02 & 9.78 & 2.75 & .36\end{array}$

\section{Strains}

Bezorgdheid m.b.t.

eigen functioneren

Gezondheidsklachten

8.34

$2.54 \quad 8.57$

2.52

8.21

2.38

.63

Klachten psychische conditie

17.86

$4.37 \quad 18.08$

4.62

17.89

4.25

.18

Verlies zelf waardering

26.06

$4.43 \quad 26.12$

4.57

26.11

4.-

.00

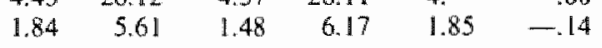

N.B. Het aantal respondenten kan zich binnen de kolommen enigszins wijzigen.

Tabel 27. Conditionerende effecten van rigiditeiw/flexibiliteit ap de relaties wussen ervaren rolonduidelijkheid en enkele stressoren en strains.

\begin{tabular}{|c|c|c|c|c|}
\hline $\begin{array}{l}\text { Relatie } \\
\text { ervaren rolonduide- } \\
\text { lijkheid met: }\end{array}$ & $\begin{array}{l}\quad 1 \\
\text { Alle hvpl. } \\
(\mathrm{N}=81)\end{array}$ & $\begin{array}{l}\text { Ml } \\
\text { Rigide hwpl. } \\
(\mathrm{N}=37)\end{array}$ & $\begin{array}{l}\text { III } \\
\text { Flexibele hvpl. } \\
(\mathrm{N}=38)\end{array}$ & $\begin{array}{l}\quad \text { IV } \\
Z \text {-waarde } \\
\text { sign. verschil } \\
\text { II en III }\end{array}$ \\
\hline & $r \quad$ sign. & 『 sign. & t sign. & \\
\hline
\end{tabular}

\section{Stressoren}

Verantwoordelijkheid

voor anderen

Niet gebruik kunnen maken

wan kennis

Rolconflict

Toekomstonzekerheid

\begin{tabular}{|c|c|c|c|c|c|c|c|}
\hline-.29 & $+\alpha$ & -31 & & -.05 & & & \\
\hline .40 & ++ & .57 & +1 & .47 & $1+$ & & \\
\hline .21 & + & .41 & + & .04 & & 1.65 & .10 \\
\hline .29 & +4 & .28 & & .32 & + & & \\
\hline
\end{tabular}

\section{Strains}

Bezorgdheid m.b.t.

eigen functioneren

Gezondheidsklachten

Klachten psychische conditie

Verlies zelfwardering

$\begin{array}{lllllll}.45++ & .48 & ++ & .50+1 & & \\ .27+ & .02 & & .49 & ++ & 2.15 & .05 \\ .40++ & .52 & ++ & .20 & & & \\ .42++ & .43+ & .51 & \end{array}$

Significan nivera $+=.05 \geqslant .005<++=.005 \geqslant$ 
Uit tabel 27 blijkt dat vooral rigide afdelingshoofden bijervaren rolonduidelijkheid weel rolconflicten ervaren.

In het begin van dit hoofdstuk wezen wij op Kahn etal. (1964). Zij veronderstellen dat juist flexibele functionarissen meer kans lopen geconfronteerd te worden met rolconflicten en daar vermoedelijk tevens een lage tolerantie voor hebben. De oorzaak daarvan is, volgens hen, de open opstelling van flexibelen, waardoor zij anderen als het ware uitnodigen druk op hen uit te oefenen. Wij beseffen goed dat een analyse met een conditionerende variabele zich niet rechtstreeks uitspreekt over een directe relatic met stressoren en strains, maar slechts nagaat hoe verbanden worden beïnvloed. Desondanks meenden ook wij dat bij ervaren rolonduidelijkheid llexibelen méér rolconflicten ervaren dan rigiden. Rigide hoofdverpleegkundigen worden verondersteld het rolconflict door bepaalde copingmechanismen uit de weg te gaan, te weten: afwenden van storende bronnen, verdringing, projectie en conformeren aan voorschriften en regels. Deaanname blijkt echter niet juist te zijn. Wij vermoeden nu dat sommige copingmechanismen van rigiden in bepaalde settings niet functioneren; dan treedt toch rolconflict op.

De flexibele afdelingshoofden blijken bijervaren rolonduidelijkheid als reactie significant meer gezondheidsklachten te ervaren dan hun rigide collega's.

8.6 Verband tussen leeftijd, geslacht en burgerlijke staat met de ervaren rol(on)duidelijkheid van hoofdverpleegkundigen

Er blijkt (zie bijlage 7 tabel 41 ) geen verband te bestaan tussen leeftijd, geslacht en burgerlijke staat wan hoofdverpleegkundigen en hun ervaren rol(on)duidelijkheid.

\subsection{Samenvatting}

Wij hebben onderzocht hoe het persoonlijkheidskenmerk rigiditeit/flexibiliteit in relatie staat met ervaren rol(on)duidelijkheid van hoofdverpleegkundigen. Wij hebben enkele auteurs geciteerd die rigiditeit omschrijven als een gedragskenmerk dat zich, in tegenstelling tot flexibiliteit, uit in een meer autoritaire houding, meer weerstand tegen veranderingen, een meer negatieve kijk op het leven, meer angst en vrees, meer intolerantie en vooroordelen, een beperktere belangstelling, minder algemene kennis en een concretere instelling.

Als copingstrategieèn van rigide mensen worden genoemd het zich afkeren van hen die storende invloeden veroorzaken, zich afhankelijk opstellen tegenover gezagsdragers, zich conformeren aan regels, dwangmatige werkgewoonten, ontkenning en projectie. In vergelijking met flexibele functionarissen schijnen rigiden een lagere tolerantie te bezitten voor werkoverbelasting en onduidelijkheden. Waarschijnlijk ontwik kelen zij verschillende copingstrategieën om zoveel mogelijk rolduidelijkheid te ervaren. Als copingstrategieën van flexibele mensen worden genoemd: teamoriëntatie, optimisme, overschatting van eigen mogelijkheden en een zich openstellen voor de invloeden van anderen. Zij schijnen, in vergelijking met rigide functionarissen een lage tolerantie te bezitten voor rolconflicten. 
Uit ons onderzoek komt naar voren dat er geen significante verschillen bestaan tussen rigide en flexibele afdelingshoofden met betrekking tot gezamenlijke taak(on)duidelijkheid. Ook zien we dat de gemiddelde gezamenlijke taak(on)duidelijkheid in beide groepen niet veel afwijkt van het gemiddelde in de totale onderzoekspopulatie hoofdverpleegkundigen. Hoewel de verschillen in de gezamenlijke taakduidelijkheid van beide groepen niet groot zijn, vermoedden wij dat de rigiden bij ongeveer dezelfde gezamenlijke taakduidelijkheid als de flexibelen, toch een grotere rolduidelijkheid zouden ervaren. Dit vermoeden is niet bevestigd. In één geval is zelfs van het tegendeel sprake. Bij flexibele afdelingshoofden resulteert een gezamenlijke taakduidelijkheid (contacten) tussen hen en directe superieuren in ervaren rolduidelijkheid $(r-.32 \operatorname{sign} . .05)$.

Wij komen opnieuw tot de conclusie dat overeenstemming over het "wat" (gezamenlijke taakduidelijkheid) niet betekent een gedeeld inzicht over het "hoe" (ervaren rolduidelijkheid).

Uit de correlatiematrix blijkt dat er een relatie bestaat tussen rigiditeit van hoofdverpleegkundigen en hun ervaren rolduidelijkheid $(\mathrm{r}-.28 \mathrm{sign} .005)$. Ook zien we dat tlexibele afdelingshoofden significant meer rolonduidelijkheid ervaren dan rigide hoofdverpleegkundigen (t-test $-2.62 \mathrm{sign} . .05$ ). Rigide afdelingshoofden blijken dus sneller van het "hoe" op de hoogte dan flexibele hoofdverpleegkundigen. Of deze overtuiging ook op feitelijke kennis steunt, kunnen wij echter niet aantonen.

Wanneer wij nagaan hoe rigide en flexibele hoofdverpleegkundigen op ervaren rol(on)duidelijkheid reageren, dan blijken rolconflicten en gezondheidsklachten in beide groepen significant van elkaar te verschillen. Rigide afdelingshoofden ervaren, in vergelijking met hun flexibele collega's, meer rolconflicten. Flexibele hoofdverpleegkundigen ervaren echter meer gezondheidsklachten.

Wij vonden geen verbanden tussen ervaren rol(on)duidelijkheid enerzijds en leeftijd, geslacht en burgerlijke staat anderzijds.

Het geheel overziend kunnen wij concluderen dat, wat de gezamenlijke taakduidelijkheid betreft, rigide, noch flexibele afdelingshoofden in een bevoorrechte positie verkeren. De gezamenlijke taakduidelijkheid mondt namelijk bij soepele noch bij starre hoofdverpleegkundigen uit in meer ervaren rolduidelijkheid.

Op een of andere wijze slagen rigide hoofdverpleegkundigen erin wat meer rolduidelijkheid te ervaren dan hun flexibele collega's. Eenmaal rolonduidelijkheid ervarend, blijken rigide hoofdverpleegkundigen meer rolconflicten te bespeuren en flexibele afdelingshoofden meer gezondheidsproblemen. 



\section{Hoofdstuk 9}

\section{Ervaren rolonduidelijkheid van hoofdverpleegkundigen en intermenselijke verhoudingen}

In dit hoofdstuk bespreken wij intermenselijke verhoudingen in relatie met ervaren rol(on)duidelijkheid. Tevens gaan wij na hoe intermenselijke verhoudingen als conditionerende variabele de relatie tussen ervaren rol(on)duidelijkheid en andere stressoren en strains beînvloeden.

Uit eerder onderzoek (Van den Bergh-Braam 1981) blijkt dat hoofdverpleegkundigen de intermenselijke verhoudingen als beter aangeven dan role-senders dat doen. Omdat hoofdverpleegkundigen zelf voor het bevorderen van goede onderlinge relaties op de afdeling verantwoordelijk geacht worden, vermoeden wij dat hierin de oorzaak ligt van deze bias.

Om zoveel mogelijk de objectiviteit te benaderen, willen wij ons daarom in eerste instantie op de meningen van role-senders baseren. Daarvoor gebruiken wij hun antwoorden op een viertal vragen die betrekking hebben op de onderlinge verstandhouding, spanningen in de relaties, verwachtingen en werkbeoordelingen ( $R$ 24/30/ $32 / 37)$. Voor een goed begrip willen wij hier benadrukken dat het hierbij gaat om visies van role-senders en niet om die van hoofdverpleegkundigen. Wij stuiten hier echter op het volgende probleem: stress is een reactie op een waargenomen bedreiging. Het is goed mogelijk dat hoofdverpleegkundigen geen problemen waarnemen waar role-senders die wél percipiëren en omgekeerd. Als zich dat voordoet onderzoeken wij dus geen stress van hoofdverpleegkundigen, maar een situatie die alleen door de role-senders zo wordt ervaren en waarop hoofdverpleegkundigen misschien helemaal niet reageren omdat ze die stimuli niet ervaren. Deze op zich waardevolle informatie geeft geen antwoord op de vraag hoeveel stress de voor hoofdverpleegkundigen minder gunstige intermenselijke verhoudingen veroorzaken en hoe deze in verband kunnen staan met ervaren rol(on)duidelijkheid. Om dit te kunnen onderzoeken dienen wij ons toch opnieuw aan te sluiten bij waarnemingen van hoofdverpleegkundigen zélf.

De analyse in dit hoofdstuk zal zich daarom baseren op twee soorten gegevens:

- waarnemingen van role-senders aangaande intermenselijke verhoudingen;

- waarnemingen van hoofdverpleegkundigen aangaande intermenselijke verhoudingen.

\subsection{Intermenselijke verhoudingen en socialle ondersteuning}

In de literatuurstudie in hoofdstuk 2 wordt zo veelvuldig gesproken over de relatie tussen mensen onderling, dat wij ons hier beperken tot een verwijzing naar dat overzicht. 
Uit als gunstig ervaren intermenselijke verhoudingen kan sociale ondersteuning resulteren.

Cob (1976) onderscheidt drie soorten sociale ondersteuning: emotionele ondersteuning, waarderingsgerichte ondersteuning en netwerkondersteuning. Hij zegt dat sociale ondersteuning één of meer van deze dimensies dient te omvatten. Sociale ondersteuning is een overbrengen van:

- informatie die ertoe leidt dat iemand gelooft dat men om hem geeft en hem sympathiek vindt. Deze boodschap komt tegemoet aan een behoefte naar begrip, vriendschap en geborgenheid (emotionele ondersteuning);

- informatie die ertoe leidt dat iemand merkt dat men hem acht en waardeert. Deze boodschap komt tegemoet aan een behoefte naar erkenning, waardering en zelfachting (waarderingsgerichte ondersteuning);

- informatie die ertoe leidt dat iemand voelt te behoren toteen groep met onderlinge banden en wederzijdse verplichtingen. Deze boodschap komt tegemoet aan een behoefte naar evaluatie van eigen opvattingen, het oplossen va n problemen en het ervaren van wederzijdse bescherming (netwerkondersteuning).

Er zijn verschillende studies verricht naar de invloed van intermenselijke verhoudingen op het werkklimaat. Wij zullen enkele aan de hand van het onderzoeksmodel bespreken.
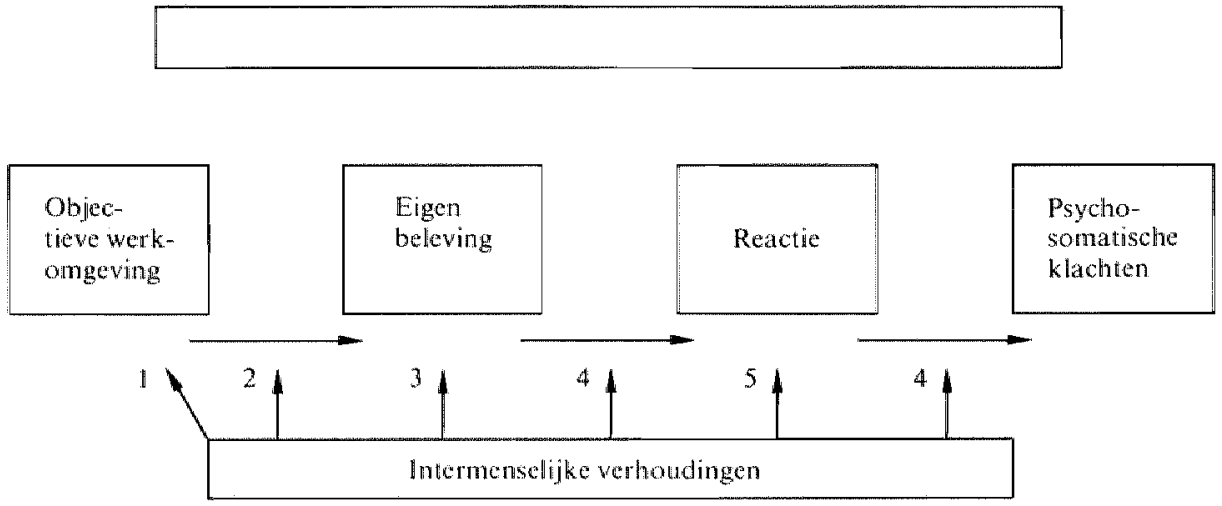

Figur 9 . Het ISR-model: intermenselijke verhoudingen.

Relatie tussen intermenselijke verhoudingen en objectieve werkomgeving (figuur 9 , pijl l)

Kaplan et al. (1977) en Kahn (1978) wijzen op de invloed die organisaties vermoedelijk uitoefenen op de mate waarin mensen in hun werksituatie sociale ondersteuning ervaren, alsmede op de aard da arvan. Dit is mogelijk doordat de organisatie invloed heeft op factoren als: aantal mensen waarmee men samenwerkt, het gemak waarmee het contact kan worden gelegd, het aantal directe contacten en de mate van wederkerigheid daarvan.

Ook omgekeerd is beinvloeding mogelijk. Gunstige of minder gunstige intermense- 
lijke verhoudingen kunnen organisaties stabiliseren of desintegreren en zodoende vorm en inhoud bepalen.

Intermenselijke verhoudingen als conditionerende/imterveniërende variabelen (figutur 9. pijl 2 en 4)

Beehr (1976) onderzocht bij 65॥ respondenten de conditionerende effecten van autonomie, sociale ondersteuning door de chef en de groepscohesie, op de relatie tussen ervaren rolonduidelijkheid met vier psychologische strains: verlies van zelfachting, depressie, ontevredenheid met het werk en met het bestaan. De conditionerende effecten van sociale ondersteuning door de chef blijken niet significant te zijn. De correlatie tussen ervaren rolonduidelijkheid en strains blijken het hoogste te zijn bij een gemiddelde ondersteuning door de chef. Bij een hoge of lage mate van ondersteuning blijken de correlaties tussen ervaren rolonduidelijkheid en strains lager te zijn. De auteurs menen dit te kunnen verklaren door te wijzen op inconsistent leiderschap dat op kan treden bij "gemiddelde support". Bij inconsistent leiderschap geven chefs in bepaalde settings wél en in andere géen sociale ondersteuning. Het is mogelijk dat bij consistent hoge of consistent lage leiderschapssupport de ondergeschikte copingstrategieën ontwikkelt, die bij inconsistente hulp niet goed mogelijk zijn. Daar het onderzoek methodologische vragen oproept (zie Reiche 1982) dienen bovenvermelde resultaten met enige scepsis te worden bekeken.

Pinneau (1975) onderzocht ook de conditionerende effecten van sociale ondersteuning op de relatie tussen een aantal stressoren en strains. Hij komt tot een gelijk luidende conclusie: sociale ondersteuning heeft inconsistente effecten. Support uit de directe omgeving blijkt soms wel en soms niet de gevolgen van stressoren te elimineren.

Relatie tussen intermenselijke verhoudingen en ervaren rol(on)duidelijkheid van hoofdverpleegkundigen (figuur 9, pijl 3)

Kahn et al. (1964) onderzocht bij 53 managers en voorlieden het verband tussen interpersoonlijke relaties en de eigen beleving van de werker. Uit dit onderzoek blijkt dat rolonduidelijkheid en rolconflict in relatie staan met minder gunstige intermenselijke verhoudingen, en weinig communicatie met mensen uit de omgeving.

Uit onderzoek van Caplan (1971), Caplanet al. (1975), Warlicht (1977)en Driessen (1979) die qua operationalisatie van de gehanteerde variabelen nagenoeg met elkaar vergelijkbaar zijn, blijkt het volgende. Degenen die veel sociale ondersteuning door hun chef ervaren, rapporteren in vergelijking met hen die daar weinig of niets van merken vooral minder rolonduidelijkheid, meer participatie in de besluitvorming, meer gebruik kunnen maken van kennis en bekwaamheden en minder geprikkeldheid in de contacten met chef en ondergeschikten. Uit deze onderzoeken blijkt tevens dat sociale ondersteuning door collega's ook invloed uitoefent op stressoren. Over het algemeen is deze uitwerking echter geringer dan bij de hulp van de directe chef.

Relatie tussen intermenselijke verhoudingen en strains (figuw 9. pijl 5)

Daar wij ons in dit onderzoek beperken tot ervaren rolonduidelijkheid, dat een 
stressor is, komt deze pijl in dit verband niet voor bestudering in aanmerking.

\section{Onderzoeksvraagsiellingen}

Gunstige intermenselijke verhoudingen, zo blijkt uit de literatuur, kunnen de werksfeer positief beinvloeden. Als role-senders zeggen goede relaties met hoofdverpleegkundigen te onderhouden, zijn dan de gezamenlijke taakduidelijk theid, de ervaren rolduidelijkheid en de reacties daarop van andere aard dan bij minder gunstige relaties?

Als hoofdverpleegkundigen zeggen goede sociale contacten en ondersteuning van medewerkers te ervaren, hoe zijn dan de gezamenlijke taakduidelijk heid, de ervaren rolduidelijkheid en de reacties daarop? Zijn er verschillen bij gunstige en minder gunstige sociale verhoudingen?

Deze vragen worden hieronder afzonderlijk geformuleerd. Zijdienen tevensals stramien van dit hoofdstuk.

Bezien vanuit de role-senders:

- Is er een relatie tussen gunstige/minder gunstige intermenselijke verhoudingen (bezien vanuit de role-senders) en gezamenlijke taak(on)duidelijkheid van hoofdverpleegkundigen (pijl 1)?

- Wat zijn de conditionerende effecten van gunstige/minder gunstige intermenselijke verhoudingen (bezien vamuit role-senders) op de relatie tussen gezamenlijke taak(on)duidelijkheid van hoofdverpleegkundigen (pijl 3)?

- Welke conditionerende effecten hebben gunstige/minder gunstige intermenselijke verhoudingen (bezien vanuit role-senders) op de relaties tussen ervaren rolonduidelijk heid van hoofdverpleegkundigen en stressoren en strains (pijl 4)?

Bezien vanuit de hoofdverpleegkundigen:

- Is er een relatie tussen gunstige/minder gunstige sociale ondersteuning (bezien vanuit hoofdverpleegkundigen) en gezamenlijke taak(on)duidelijkheid van hoofidverpleegkundigen (pijl I)?

- Wat zijn de conditionerende effecten van gunstige/minder gunstige sociale ondersteuning (bezien vanuit hoofdverpleegkundigen) op de relatie tussen gezamenlijke taak(on)duidelijkheid en ervaren rol(on)duidelijkheid (pijl 2)?

- Is er een relatic tussen gunstige/minder gunstige sociale ondersteuning (bezien vanuit hoofdverpleegkundigen) en ervaren rol(on)duidelijkheid van hoofdverpleegkundigen (pijl 3)?

- Welke conditionerende effecten hebben gunstige/minder gunstige sociale ondersteuning (bezien vanuit hoofdverpleegkundigen) op de relaties tussen ervaren rol(on)duidelijkheid van hoofdverpleegkundigen en stressoren en strains? (pijl 4)?

\section{Constructie en benoemen nieuwe variabelen}

Daar uit de analyse blijkt (hoofdstuk 7) dat directe superieuren en specialisten tamelijk eensluidende antwoorden geven op vragen die dimensies van intermenselijke verhoudingen omvatten en gediplomeerden en leerlingen eveneens, spraken wij van twee clusters rondom hoofdverpleegkundigen. Deze clustervorming is begrijpelijk. Directe superieuren en specialisten zullen als respectievelijk hiërarchische 
chef en functionele chef andere aspecten in hun onderliage relaties ervaren dan gediplomeerden en leerlingen.

Daarom willen wij in de hiernavolgende analyse met deze twee clusters werken: directe superieuren tezamen met specialisten en gediplomeerden tezamen met leerling-verpleegkundigen.

Deze nieuwe variabelen willen wij noemen:

IVWSS $=$ Intermenselijke verhoudingen, waargenomen door directe superieuren en specialisten.

IVWGL $=$ Intermenselijke verhoudingen, wargenomen door gediplomeerden en leerlingen.

Wij verkriggen deze variabelen uit antwoorden op vragen $\mathrm{R} 24 / 30 / 32 / 27$.

Van deze vier vragen tellen wij de somscore tezamen van superieuren met specialisten en van gediplomeerden met leerlingen. Wij dichotomiseren beide variabelen in als gunstig waargenomen intermenselijke verhoudingen (code 1) en als minder gunstig waargenomen intermenselijke verhoudingen (code 2).

9.2 Gezamenlijke taak(on)duidelijkheid bij gunstige/minder gunstige intermenselijke verhoudingen (zoals waargenomen door role-senders)

In hoofdstuk 5 hebben wij de gemiddelden berekend van de gezamenlijke taak(on)duidelijkheid tussen hoofdverpleegkundigen en role-senders. Thans gaan wij na of bij gunstige of minder gunstige intermenselijke verhoudingen (zoals ervaren door role-senders) hoofdverpleegkundigen meer of minder gezamenlijke taakduidelijkheid ervaren.

Uit de tabellen 43 en 44 (bijiagen 9 en 10) blijkt dat er geen enkel significant verschil bestaat tussen de gemiddelden van de gezamenlijke taak(on)duidelijkheid. Er is sprake van middelmatige taakduidelijkheid, zowel bij gunstige als bij minder gunstige intermenselijke verhoudingen (zoals ervaren door rolle-senders).

Hoewel de verschillen niet groot zijn, blijkt bij gunstige relaties - zoals waargenomen door gediplomeerden en leerlingen - de gezamenlijke taakduidelijkheid tets groter dan bij minder gunstige relaties.

In een aantal gevallen geld dit ook voor de gunstige relaties - zoals wailgenomen door superieuren en specialisten. De verschillen zijn echter zo klein dat wij er geen waarde aan mogen hechten.

9.3 Conditionerende effecten van gunstige/minder gunstige intermenselijke verhoudingen (zoals ervaren door role-senders) op de relatie tussen gezamenlijke taak(on)duidelijkheid en ervaren rol(on)duidelijkheid

De scores van de variabelen lopen niet in dezelfde richting.

Gezamenlijke takonduidelijkheid/duicielijkheid scoort 0 - 5, ervaren rolonduidelijkheid/duidelijkheid $15-0$.

Gezien het scoreverloop verwachten wij een negatieve correlatie tussen beide variabelen.

Uit de tabellen 45 en 46 bijlagen 11 en 12 blijkt dat slechts de helft van de correlaties in 
de verwachte negatieve richting loopt. Er is slechts één significant verband: als de intermenselijke verhoudingen, zoals waargenomen door gediplomeerden en leerlingen, minder gunstig zijn, dan leidt de gezamenlijke taakduidelijkheid tussen hoofdverpleegkundigen en directe superieuren tot ervaren rolduidelijkheid van hoofdverpleegkundigen.

9.4 Relatie tussen gunstige/minder gunstige intermenselijke verhoudingen (bezien vanuit role-senders) en ervaren rol(on)duidelijkheid van hoofdverpleegkundigen

Als directe superieuren en specialisten zeggen gunstige relaties te onderhouden met hoofdverpleegkundigen, ervaren afdelingshoofden dan tevens méér rolduidelijkheid dan bij minder gunstige intermenselijke verhoudingen (bezien vanuit rolesenders)? Verschillen de reacties van hoofdverpleegkundigen op ervaren rol(on)duidelijkheid naargelang role-senders zeggen gunstige of minder gunstige contacten met hen te hebben? Uit de tabellen 47 en 48 bijlagen 13 en 14 blijkt, dat gunstige noch minder gunstige socyale relaties (bezien vanuit role-senders) effecten sorteren bij ervaren rol(on)duidelijkheid of bij de reacties daarop.

9.5 Conditionerende effecten van gunstige/minder gunstige intermenselijke verhoudingen (bezien vanuit role-senders) op de relaties tussen ervaren rol(on)duidelijkheid en enkele stressoren en strains

Worden de relaties tussen ervaren rol(on)duidelijkheid en andere stressoren en strains versterkt of verzwakt bij gunstige/minder gunstige intermenselijke verhoudingen (zoals waargenomen door superieuren en specialisten)?

Uit tabel 28 blijkt dat bij gunstige intermenselijke verhoudingen (zoals waargenomen door superieuren en specialisten) de relatie wordt versterkt tussen ervaren rolonduidelijkheid en de mening van hoofdverpleegkundigen dat zij onvoldoende gebruik kunnen maken van hun kennis en bekwaamheden.

Bij minder gunstige intermenselijke verhoudingen (zoals waargenomen door superieuren en specialisten) wordt de relatie versterkt tussen ervaren rolonduidelijkheid en gezondheidsklachten.

Uit tabel 29 blijkt dat bij gunstige intermenselijke verhoudingen (zoals waargenomen door gediplomeerden en leerlingen) de relatie wordt versterkt tussen ervaren rolonduidelijkheid en de mening van hoofdverpleegkundigen dat zij onvoldoende gebruik kunnen maken van hun kennisen bekwaamheden. Ditzelfde zagen wijook in tabel 28 .

Dat bij gunstige onderlinge verhoudingen (zoals waargenomen door gediplomeerden en leerlingen) de relatie tussen ervaren rolonduidelijkheid en het verlies van zelfwaardering toeneemt, mag misschien in eerste instantic verwondering wekken. Hierbij dienen wij echter te wijzen op het feit dat de gunstige relatie een gezichtspunt is, afkomstig van gediplomeerden en leerlingen. Jonge mensen uiten 
Tabel 28. Condirionerende frecten wom gunstige/minder gunsige WWSS op de rehtre tussen ernaren

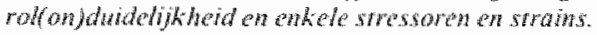

\begin{tabular}{|c|c|c|c|}
\hline I & II & III & IV \\
\hline $\begin{array}{l}\text { Totale } \\
\text { groep }\end{array}$ & $\begin{array}{l}\text { Gunstige } \\
\text { IVWSS }\end{array}$ & $\begin{array}{l}\text { Minder } \\
\text { gunstige } \\
\text { IVWSS }\end{array}$ & $\begin{array}{l}\text { Sign, wersehil } \\
\text { tussen II on } \\
\text { III }\end{array}$ \\
\hline$(N=81)$ & $(N=4 I)$ & $(\mathrm{N}=38)$ & \\
\hline r sign. & $r \quad \operatorname{sign}$. & $r \quad$ sign. & Z-wastre sign \\
\hline
\end{tabular}

Relatie

erwatren rolonduidelijk heid met

\section{Stressoren}

Verantwoondelijkheid

voor anderen

Niet gebruk kunnen

maken wan kennis

Rolcontlict

Toekomstonzekerheid

$\begin{array}{rrrrr}-.29++ & -.30 & -.16 \\ & & & \\ .40++ & .65 & & \\ .21+ & .31 & .33 & + \\ .29++ & .22 & .30 & .35 & +\end{array}$

$1.97 \quad .05$

\section{Strains}

Bezorgdheid m.b.t.

eigen functioneren

Gezondheidsklachten

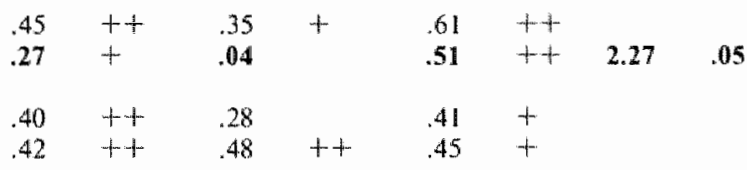

Sign. niveau $t=.05 \geqslant .005<+t=.005 \geqslant$

Tabel 29. Conditionerende effecten van gunstigerminder gunstige $I V W G L$ op de relatim tussen erwaren rolonduidelijk heid en enkele stressoren en strains.

\begin{tabular}{llll}
\multicolumn{1}{c}{ I } & \multicolumn{1}{c}{ II } & \multicolumn{1}{c}{ III } & \multicolumn{1}{c}{ IV } \\
Totale & Gunstige & Minder & Sign. verschil \\
groep & IVWGL & ghnstige & thissen II an \\
$(\mathrm{N}=81)$ & $(\mathrm{N}=34)$ & $(\mathrm{N}=4 \mathrm{~L})$ & III \\
$\mathrm{r}$ sign. & $\mathrm{r}$ sign. & $\mathrm{r}$ sign. & Z-waarde sign.
\end{tabular}

Relatie

erwaren rolonduidelijkheid met

\section{Stressoren}

Verantwoordelinkheid voor anderen

Niet gebruik kunnen

maken van kennis

Rolconflict

Toekomstonzekerheid

$\begin{array}{rrrr}-.29++ & -.08 & -.26 \\ .40++ & .70 & \\ .21++ & .36 \\ .29++ & .29 & .27 \\ .42+ & .20\end{array}$

2.060 .05

\section{Strains}

Bezorghteid m, b.t.

elgen functioneren

Gezondheidsklachten

K.llachten psychische

conditie

Verlies zelfwardering

$\begin{array}{llll}.45++ & .48+t & .55+t \\ .27+ & .25 & & .18 \\ .40+t & 40+ & .42 & \\ .42+ & .64++ & .27\end{array}$

2.01 .05

Sigra. niveau $t=.05 \geqslant .005<++=.005 \geqslant$ 
vriendschappelijke gevoelens niet zelden in een openhartigheid die door ouderen niet altijd als wriendschappelijk wordt ervaren.

Nu doen wij in de volgende viet paragrafen dezelfde exercities als in de vier voorafgaande, met dien verstande dat de meningen over intermenselijke verhoudingen nu ontleend worden aan antwoorden van hoofdverpleegkundigen.

9.6 Gezamenlijke taak(on)duidellijkheid bij gunstige/minder gunstige sociale ondersteuning (bezien vanuit hoofdverpleegkundigen)

Uit de tabellen 49 en 50 bijlagen 15 en 16 blijkt dat er geen enkel significant verschil bestaat tussen de gemiddelden van de gezamenlijke taak(on)duidelijkheid bij gunstige of minder gunstige sociale ondersteuning door superieuren. Ook de sociale ondersteuning door collega's sorteert weinig effect met betrekking tot de gezamenlijke taakduidelijkheid. In één geval is zelfs sprake van een grotere gezamenlijke taakduidelijkheid (contacten) tussen hoofdverpleegkundigen en gediplomeerden wanneer de sociale ondersteuning door collega's minder gunstig is (t-test -2.87 sign. .005).

9.7 Conditionerende effecten van gunstige/minder gunstige sociale ondersteuning (bezien vanuit hoofdverpleegkundigen) op de relatie tussen gezamenlijke taak(on)duidelijkheid en ervaren rol(on)duidelijkheid

De scores van de variabelen lopen niet in dezelfde richting. Gezamenlijke taakonduidelijkheid/duidelijkheid scoort $0-5$, ervaren rolonduidelijkheid/duidelijkheid 15-0. Gezien het score-verloop verwachten wij een negatieve correlatie tussen beide variabelen.

Uit de tabellen $5 \rrbracket$ en 52 bijlagen 17 en 18, blijkt dat gunstige noch minder gunstige sociale ondersteuning (bezien vanuit hoofdverpleegkundigen) effecten sorteren bij de relaties gezamenlijke taak(on)duidelijkheid/ervaren rol(on)duidelijkheid. Niet alle correlaties lopen in de verwachte richting. Bovendien blijkt dat de (niet verwachte) positieve verbanden vaker worden aangetroffen bij gunstige dan bij minder gunstige sociale support.

9.8 Relatie tussen gunstige/minder gunstige sociale ondersteuning (bezien vanuit hoofdverpleegkundigen) en ervaren rol(on)duidelijkheid van hoofdverpleegkundigen

Wij brachten herhaaldelijk de opvatting naar voren dat ervaren rolonduidelijkheid samenhangt met minder gunstige intermenselijke verhoudingen. Als hoofdverpleegkundigen weinig sociale ondersteuning ervaren van directe superieuren en collega's, rapporteren zij dan tevens meer rolonduidelijkheid dan bij gunstiger sociale support? Verschillen de reacties van hoofdverpleegkundigen naargelang zij gunstige of minder gunstige sociale contacten ervaren?

Uit de correlatiematrix blijkt dat er inderdaad verbanden bestaan tussen ervaren rolonduidelijkheid van hoofdverpleegkundigen en - volgens hun mening - onvoldoende ondersteuning door directe superieuren ( $r .35$ sig. .001) en onvoldoende ondersteuning door collega's ( $\mathrm{r} .25$ sign. .01). 
Uit de volgende tabel blijkt eveneens dat bij minder gunstige sociale ondersteuning door directe superieuren, hoofdverpleegkundigen significant méer rolonduidelijkheid ervaren.

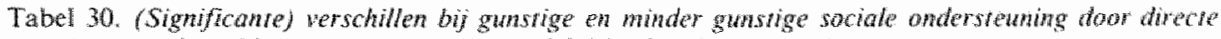

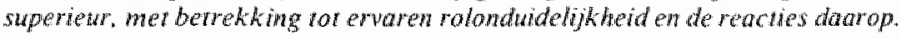

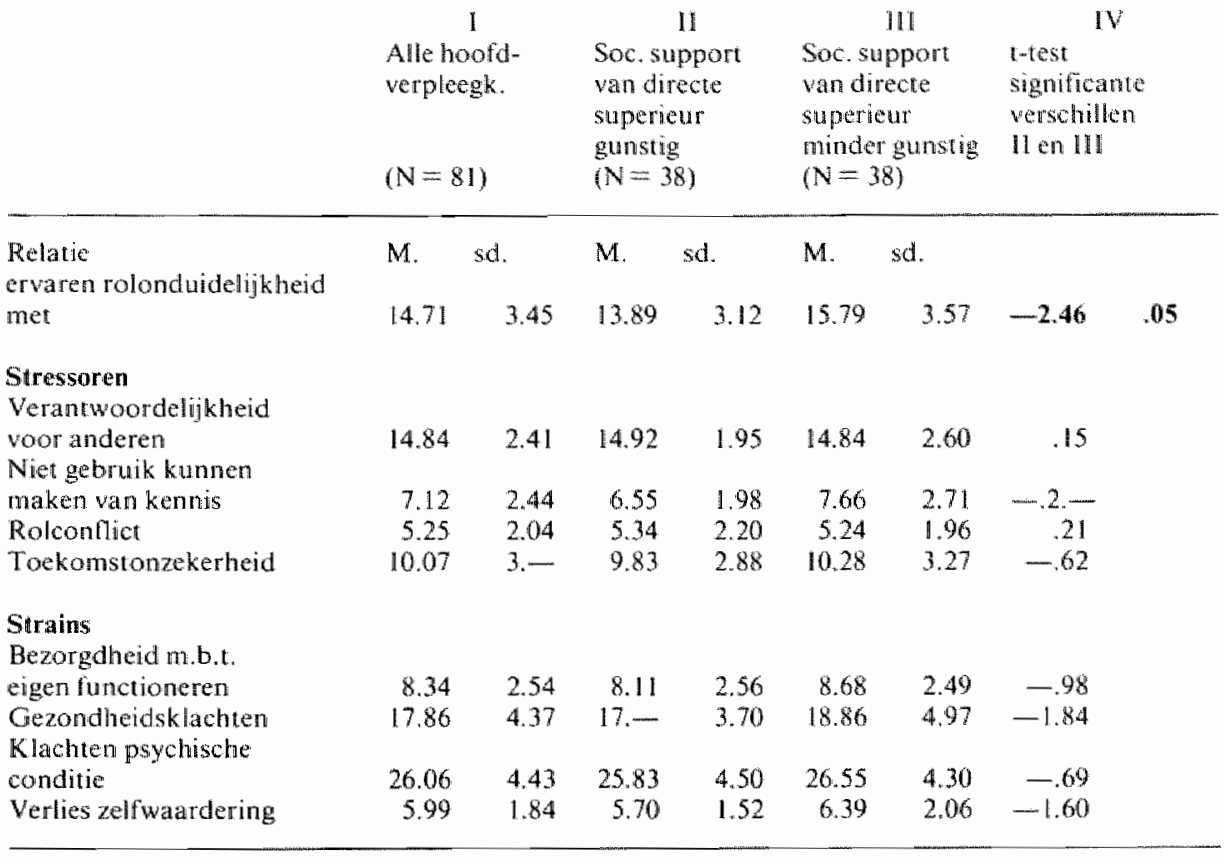

N.B. Het aantal respondenten kan zich binnen de kolommen enigszins wijzigen.

Bij minder gunstige sociale ondersteuning door collega's (bezien vanuit hoofdverpleegkundigen) ervaart de hoofdverpleegkundige niet alleen meer rolonduidelijkheid, maar tevens, als reactie op de ervaren rolonduidelijkheid, minder verantwoordelijkheid voor anderen, meer gebruik kunnen maken van kennis ern bekwaamheden, meer bezorgdheid met betrekking tot eigen functioneren, meer psychische klachten en meer verlies van zelfwaardering. Zie tabel 3i.,

9.9 Conditionerende effecten van gunstige/minder gunstige sociale ondersteuning (zoals ervaren door hoofdverpleegkundigen) op de relaties tussen ervaren rolonduidelijkheid en enkele stressoren en strains

Worden de relaties tussen ervaren rol(on)duidelijkheid en andere stressoren en strains versterkt of verzwakt bij gunstige/minder gunstige sociale ondersteuning (zoals ervaren door hoofdverpleegkundigen)?

Uit tabel 32 blijkt dat, wanneer hoofdverpleegkundigen gunstige sociale ondersteuning van hun directe superieuren ondervinden, de relaties tussen rolonduidelijkheid en rolconflict worden versterkt. 
Tabel 31. (Signifrante) werschillen bij gunstige ew minder gunstige sociale ondersteuning door collega"smet

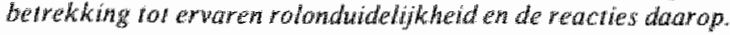

\begin{tabular}{llll}
\multicolumn{1}{c}{1} & \multicolumn{1}{c}{ II } & \multicolumn{1}{c}{ III } & \multicolumn{1}{c}{ IV } \\
Alle hoofd- & Soc. support & Soc. support & t-1est \\
verpleegk. & collega"s & collega"s & significant \\
& gunstig & minder gunstig & verschil \\
$(\mathrm{N}=81)$ & $(\mathrm{N}=29)$ & $(\mathrm{N}=45)$ & II en III
\end{tabular}

Relatie

ervaren rolonduidelijkheid

met
M. s.d.

$14.71 \quad 3.45 \quad 13.45$
M. s.d.
M. s.d.

$15.80 \quad 3.58 \quad-3.13$

.001

\section{Stressoren}

Verantwoordelijkheid

voor anderen

Niet gebruik kunnen

maken van kenris

Rolconflict

Tokkonstonzekerheid

$\begin{array}{rrrrrrrr}14.84 & 2.41 & 15.62 & 1.64 & 14.30 & 2.49 & 2.75 & .005 \\ .712 & 2.44 & 6.31 & 2.12 & 7.60 & 2.56 & -2.34 & .05 \\ 5.25 & 2.04 & 5.07 & 1.80 & 5.30 & 2.08 & -.45 & \\ 10.07 & 3 . & 9.27 & 2.75 & 10.45 & 3.19 & -1.66 & \end{array}$

Strains

Bezorgdheid $m . b . t$.

eigen functioneren

Gezondheidsklachten

2.54

7.34

2.65

9.11

$2.26-2.95$

18.25

$4.24 \quad-.71$

.001

Klachten psychische

conditie

Verlies zelfwaardering

$4.37 \quad 17.46$

4.86

4.07

ป. $9 \rrbracket$
27.19

6.55
$4.26 \quad-2.53$

$1.71-2.11$

N.B. Het aantal respondenten kan zich binnen de kolommen enigszins wijzigen.

Tabel 32. Conditionerende effecten van gunstige/minder gunstige sociale ondersteuning door directe superiewren op de refatie ussen erwaren rolonduidelijk heid en enkele stressaren en strains.

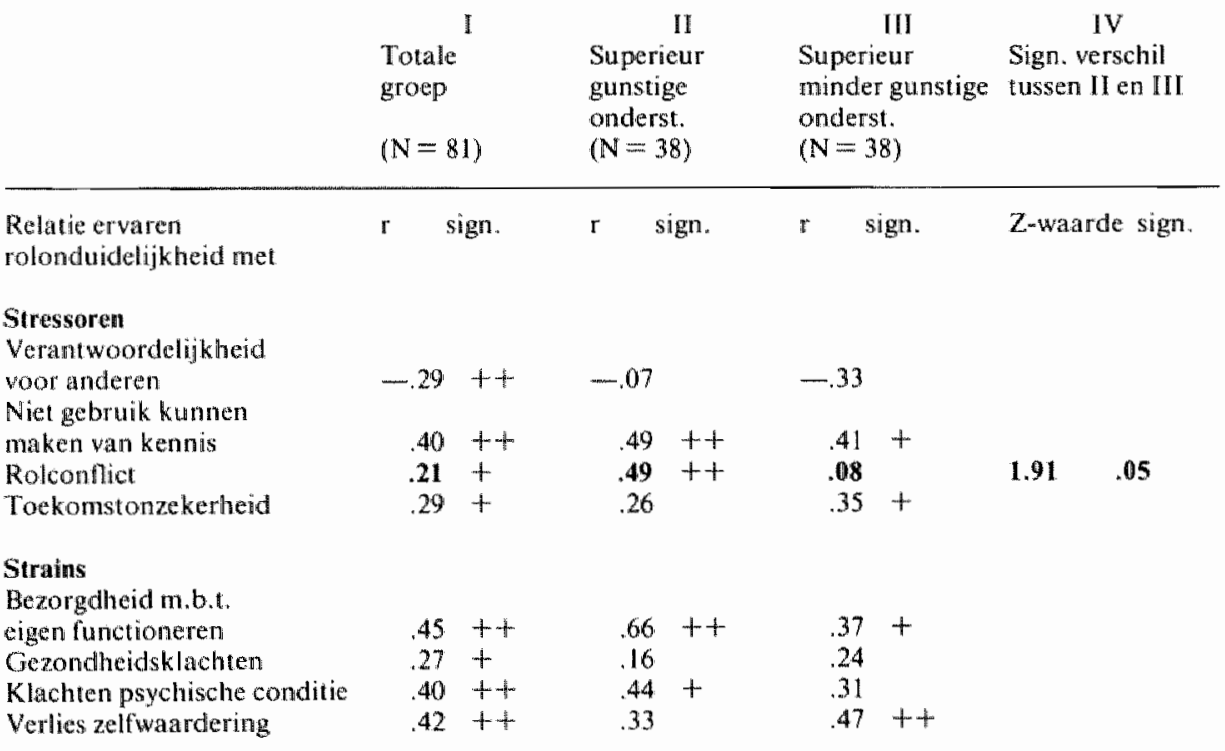

Sign. niveau $+=.05 \geqslant .005<++=.005 \geqslant$ 
Wij denken dit als volgt te kunnen verklaren. Wanneer de afdelingshoofden goede verstandhouding hebben met hun superieuren, zullen zij trachten aan hun wensen, goedkeuring en verwachtingen te beantwoorden. Rolonduidelijkheid interfereert met deze pogingen. $\mathrm{Bij}$ minder gunstige sociale ondersteuning zullen hoof dverpleegkundigen niet zoveel moeite doen de goede relatie in stand te houden, zodat de effecten van ervaren rolonduidelijkheid (rolconflicten en bezorgdheid ten aanzien wan eigen functioneren) niet zo scherp worden gevoeld.

Tabel 33. Condinonerende effecten wan gunstrge/ minder gunstige sociate onderstewning door collega'sopde relatie vussen ervaren rolomdsidelijk heid on enkele stressoren en strains.

\begin{tabular}{|c|c|c|c|c|c|c|}
\hline \multirow[b]{2}{*}{$\begin{array}{l}\text { Relatie ervaren } \\
\text { rollonduidelijkheid met }\end{array}$} & \multicolumn{2}{|c|}{$\begin{array}{l}\text { Totale } \\
\text { groep } \\
(\mathbb{N}=81)\end{array}$} & \multicolumn{2}{|c|}{$\begin{array}{l}\quad \text { Il } \\
\text { Collega"s } \\
\text { gunstige } \\
\text { ondersteuning } \\
(N=49)\end{array}$} & $\begin{array}{l}\quad \text { III } \\
\text { Collega"s } \\
\text { minder gunstige } \\
\text { ondersteuning } \\
(\mathbb{N}=25)\end{array}$ & \multirow{2}{*}{$\begin{array}{l}\text { IV } \\
\text { Sign. verschil } \\
\text { tussen II en III }\end{array}$} \\
\hline & $r$ & sign. & r & sign & sign. & \\
\hline \multicolumn{7}{|l|}{ Stressoren } \\
\hline $\begin{array}{l}\text { woor anderen } \\
\text { Niet gebruik kunnen }\end{array}$ & -.29 & $+x$ & -25 & & -.24 & \\
\hline maken van kennis & .40 & $+t$ & 47 & $4+$ & $39+$ & \\
\hline Rolconflict & .21 & + & .37 & + & .13 & \\
\hline Toekomstonzekerheid & .29 & + & .39 & + & .22 & \\
\hline \multicolumn{7}{|l|}{ Strains } \\
\hline $\begin{array}{l}\text { Bezorgdheid m.b.t. } \\
\text { eigen functioneren }\end{array}$ & .45 & ++ & .62 & ++ & .29 & \\
\hline Gezondbeidsklachten & .27 & H & .33 & + & .04 & \\
\hline Klachten psychische conditie & .40 & ++ & .44 & ++ & .21 & \\
\hline Verlies zelfwardering & .42 & $+t$ & .42 & + tw & $.44+$ & \\
\hline
\end{tabular}

Sign. niveau $+=.05 \geqslant .005<+t=.005 \geqslant$

\subsection{Samenvatting}

Wij onderzochten op twee manieren hoe intermenselijke verhoudingen de ervaren rol(on)duidelijkheid van hoofdverpleegkundigen kunnen beïnvloeden.

Allereerst gingen wij na hoe gunstige/minder gunstige sociale rela ties zoals ervaren door role-senders, effecten hebben op ervaren rol(on)duidelijkheid van hoofdverpleegkundigen.

Vervolgens zochten wij naar eventuele verbanden tussen gunstige/minder gunstige onderlinge verhoudingen, bezien vanuit hoofdverpleegkundigen en ervaren rol(on)duidelijkheid van het afdelingshoofd.

Gunstige of minder gunstige intermenselijke relaties (zoals waargenomen door rolesenders) houden geen verband met méér of minder gezamenlijke taakduidelijkheid. Ook vonden wij geen conditionerende effecten van gunstige/minder gunstige inter- 
menselijke werhoudingen op de relatie taak(on)duidelijkheid/ervaren roll(on)duidelijkheid.

Uit de analysen blijkt dat noch gunstige, noch minder gunstige sociale relaties (bezien wanuit role-senders) effecten sorteren bij ervaren rol(on)duidelijkheid of bij de reacties daarop.

Wij vonden vier interactie-effecten van sociale relaties (bezien vanuit role-senders) op de verbanden tussen ervaren rol(on)duidelijk heid en anderestressoren en strains. Zo blijkt bij minder gunstige relaties (waargenomen door superieuren en specialisten) het verband tussen ervaren rol(on)duidelijkheid van hoofdverpleegkundigen en hun gezondheidsklachten toe te nemen. Gunstige verhoudingen (waargenomen door gediplomeerden en leerlingen) blijken de relatie te wersterken tussen ervaren rol(on)duidelijkheid van hoofdverpleegkundigen en het afnemen van hun zelfachting. Deze, op het eerste gezicht misschien opmerkelijke bevinding, hebben wij verklaard door te wijzen op het feit dat de gunstige relatie een mening is van rolesenders. Jonge mensen, als leerlingen nu eenmaal zijn, uiten hun vriendschappelijke gevoelens niet zelden op een wijze die ouderen niet altijd als vriendschappelijk ervaren.

Bij gunstige relaties (ervaren door alle role-senders) blijkt het verband tussen ervaren rolonduidelijkheid van hoofdverpleegkundigen en hun klachten over het niet voldoende gebruik kunnen maken van kennis en bek waamheid, toe te nemen.

Wij verklaren dit als volgt: de tijd en inzet die hoofdverpleegkundigen nodig hebben om een goede werksfeer op de afdeling te bevorderen, laat weinig mogelijkheden open om de verpleegkundige vakkennis te benutten.

In het deel dat uitgaat van de waarnemingen van hoofdverpleegkundigen komen wij aanvankelijk tot dezelfde onderzoeksbevindingen als zojuist beschreven. Gunstige of minder gunstige sociale ondersteuning (zoals ervaren door hoofdverpleegkundigen) beïnvloedt de gezamenlijke taak(on)duidelijkheid niet. Ook de conditionerende effecten van intermenselijke verhoudingen (bezien vanuit hoofdverpleegkundigen) op de relatie taak(on)duidelijkheid - ervaren rol(on)duidelijkheid, zijn afwezig.

Wanneer hoofdverpleegkundigen onvoldoende sociale support ervaren van directe superieuren, ervaren zij meer rolonduidelijkheid dan bij gunstige sociale ondersteuning ( $\mathrm{r} .35$ sign. .001 ). Ditzelfde zien we bij gunstige/minder gunstige sociale ondersteuning door collega's ( $\mathrm{r} .25 \mathrm{sign}$. .01). Ook zien we dat opnieuw bevestigd wanneer wij de gemiddelden van beide groepen op significante verschillen toetsen.

Minder gunstige sociale ondersteuning door collega's blijkt bij hoofdverpleegkundigen bovendien de reacties op ervaren rolonduidelijkheid te verhevigen, zoals minder verantwoordelijk heid woor anderen te ervaren, meer gebruik kunnen maken van kennis en bekwaamheden, meer bezorgdheid over het eigen functioneren, meer psychische klachten en meer verlies van zelfwaardering.

Wanneer hoofdverpleegkundigen gunstige ondersteuning ervaren van hun directe superieuren, blijkt het verband tussen ervaren rolonduidelijkheid en rolconflicten toe te nemen; dit zien we echter niet bevestigd in tabel 47 bijlage 13 . 


\section{Hoofdstuk 10}

\section{Samenvatting en discussie}

Het onderzoek werd opgezet om de problemen te bestuderen die hoofdverpleegkundigen ondervinden bij de uitoefening van hun functie. Hoofdverpleegkundigen worden beschouwd als sleutelfiguren op de ziekenafdeling. Door een onderzoek naar de werkspanningen van afdelingshoofden wilden wij een basis leggen voor maatregelen ter verbetering van de verpleegkundige hulpverlening.

In het onderzoek participeerden 30 ziekenhuizen. De steekproef werd gestratificeerd op ziekenhuisgrootte, type afdeling en regio. Wij hanteerden de zogenaamde role-setbenadering. Hierin staat de hoofdverpleegkundige centraal. Als role-senders fungeren directe superieuren, specialisten, gediplomeerden en leerling-verpleegkundigen.

Het aantal respondenten bedraagt $600 ; 120$ van iedere groep. Het onderzoek baseert zich op het stressmodel ontleend aan Kahn (1964) en French en Caplan (1972).

In het vooronderzoek werden de eerste gegevens in twee rapporten verwerkt (Van den Bergh-Braam 1982, 1983). Uit de daarin gepresenteerde bevindingen blijkt dat werkoverbelasting en rolonduidelijkheid twee belangrijke spanningsbronnen van hoofdverpleegkundigen zijn.

Een van beide problemen wilden wij nader bestuderen. Daar, mede vanwege onze onderzoeksopzet, rolonduidelijkheid minder subjectief kan worden gemeten dan werkoverbelasting, heb ben wij als centraal thema voor dit proefschrift gekozen voor een nadere analyse van de rolonduidelijkheid van hoofdverpleegkundigen.

\section{Beperkingen}

Uit het grote geheel bleven uiteindelijk - tengevolge van het weigeren van medewerking door één ziekenhuis en het onvolledige of niet beschikbaar komen van respons uit een aantal role-sets -81 role-sets over. Door de selectie blijken uit grotere ziekenhuizen relatief méér role-sets buiten het onderzoek te blijven dan uit de kleinere en middelgrote instituten. Bij het generaliseren van de onderzoeksbevindingen dienen wij daarom enige voorzichtigheid te betrachten ten opzichte van ziekenhuizen uit "functieclassificatie 4" en academische klinieken. De selectie heeft echter geen wijziging gebracht in de getalsverhoudingen tussen type afdeling en regio.

Aan het onderzoek kleven nog enkele beperkingen. Zo is de samenstelling van de role-set niet zo uitgebreid als we gewenst hadden. Belangrijke groeperingen als bijvoorbeeld fysiotherapeuten, laboranten, welfare-personeel, secretaressen en keukenassistenten werden niet ondervraagd. Graag hadden wij tenminste één van 
deze groepen ook in het onderzoek betrokken. Daar we met de ziekenhuisdirecties geen eenstemmigheid konden bereiken over de vraag welke groep dan daarwoor in aanmerking $\mathrm{kwam}$, moesten wij van dit voornemen afzier-

On organisatorische en praktische redenen komen ook de meningen van patiënten in deze studie niet voor. Dat wij de verwachtingen van patiënten niet kunnen relateren aan de taakpercepties en ervaren rol(on)duidelijkheid van hoofdverpleegkundigen, blijft een punt dat wij betreuren.

Verder heeft het onderzoek alleen betrekking op de werksituatie. Andere sectoren, zoals het gezins- en verenigingsleven, blijven buiten beschouwing. Wij vroegen wel natar de sociale ondersteuning door de partner, maar daar 63 procent van de afdelingshoofden zegt alleen te leven, konden wij deze variabele in de analyse niet handhaven. Wij realiseren ons dat dit een belangrijke beperking kan zijn voor de verklaring van de verschillen in strains.

Daar wijgeen factoranalysen konden uitvoeren op de taak/contactopvattingen van hoofdverpleegkundigen, is dat gedeelte van het onderzoek beperkt gebleven tot het constateren van opvattingen van role-senders, terwijl wij liever waren overgegaan tot een vergelijking van verwachtingen tussen hoofdverpleegkundigen en role-senders. Hoewel wij in vragenlijsten uitvoerig hebben geïnformeerd naar verschillende vormen van verpleging en de invloed daarvan op het functioneren van hoofdverpleegkundigen, bleken de antwoorden van dien aard dat wij hen voor verdere analysen niet konden gebruiken. Vooral het kleine aantal respondenten dat verk laarde cen andere worm dan functionele verpleging te praktiseren, maakte een zinvoile invoeging van deze variabele onmogelijk. Wij beseffen echter goed dat - door de sinds 1980 toegenomen teamverpleging - rolonduidelijkheid van hoofdverpleegkundigen groter kan zijn dan thans in dit onderzoek naarvoren komt. Ditzelfde geldt voor de sluitings- of fusieproblematiek, waarnaar wij informeerden, maar waarop wij te weinig concrete antwoorden ontvingen.

De schalen die sociale ondersteuning trachten te meten van directe chef, collega's, anderen op het werk en verwanten/vrienden, lijken dit op een globale wijze te doen; zij meten eerder potentieel beschikbare dan feitelijk gemobiliseerde sociale ondersteuning.

Ook willen wij wijzen op de subjectieve bias die met name de data over ziekteverzuim kan vertekenen. Wij ontvingen deze gegevens van de respondenten zelf en niet van de ziekenhuisadministratie. Onderzoekservaringen leren dat de cijfers die organisaties verstrekken, betrouwbaarder zijn dan mededelingen van betrokkenen.

Tenslotte willen wij wijzen op het feit dat de analysen werden verricht op gegevens die op één tijdstip werden verzameld (cross-sectional design). Dit type onderzoek leent zich niet voor toetsing van causale verbanden. De interpretatie die wij hier en daar geven mogen dus niet worden beschouwd als een oorzaak - gevolg relatie, maar als mogelijke verklaring.

\section{Samenvatting bevindingen}

De voornaamste bevindingen van dit onderzoek willen wij presenteren als antwoorden op de tien onderzoeksvragen uit hoofdstuk 3. De onderstaande nummeringen 
verwijzen naar de daarmede corresponderende vraagnummers uit dat hoofdstuk.

\section{Hoofdstuk 5}

1. Een van de belangrijkste bevindingen van het onderzoek is, dat gezamenlijke taakduidelijkheid tussen hoofdverpleegkundigen en role-senders niet leidt tot ervaren rolduidelijkheid van hoofdverpleegkundigen; soms observeren wij zelfs het tegendeel.

Wanneer hoofdverpleegkundigen en role-senders het met elkaar eens zijn over de vijf belangrijkste taken van hoofdverpleegkundigen (die bijvoorbeeld kunnen bestaan uit het begeleiden van de patiënt, het coördineren van werkzaamheden, het zorgdragen voor een adequate personeelsbezetting, het handhaven van een prettige werksfeer en het begeleiden van het artsenbezoek) dan is dat een teken van gezamenlijke taakduidelijkheid en weet de hoofdverpleegkundige heel goed "wat" ze moet doen, maar nog niet "hoe": zij ervaart rolonduidelijkheid bij gezamenlijke taakduidelijkheid. Verschillende behandelingsmethoden, visies op patiëntenbeleid, meningen over samenwerkingsstrategieën, personeelstoewijzing en uiteenlopende belangen en motivaties bepalen onder andere de verwachtingen ten aanzien van het rolgedrag van hoofdverpleegkundigen. Deze uiteenlopende gedragingen en verwachtingen krista liseren moeilijk uit tot een duidelijk omschreven verwachtingspatroon dat hoofdverpleegkundigen enig houvast kan bieden. Wij vermoeden zelfs dat sommige groeperingen hun motivaties en strevingen verbergen. De hierdoor ontstane ondergrondse stromingen en informele machtsuitoefeningen beperken een duidelijk inzicht van hoofdverpleegkundigen. Deze tendens zal vermoedelijk door de komende ontwikkelingen in het ziekenhuis eerder toe-dan afnemen. Wij denken daarbij aan de onzekerheden over de nieuwe budgetteringssystemen, toenemende beddenreductie, snellere patiëntendoorstroming, beperking van verpleegkundig personeel, werkloosheidsbedreigingen en grotere verkilling van de ziekenhuissfeer. Ziekenhuisdirecties die rolonduidelijkheid van hoofdverpleegkundigen willen bestrijden, kunnen niet wolstaan met louter taaktechnische instructies.

\section{Hoofdstuk 6}

2. Als tweede belangrijke punt van deze studie noemen wij de afwijkende inzichten tussen hoofd verpleegkundigen en role-senders over hun onderlinge verstandhouding, spanningen, verwachtingen en werkbeoordeling (gezamenlijke rolonduidelijkheid).

Er bestaan significante verschillen tussen hoofdverpleegkundigen enerzijds en anderzijds directe superieuren, specialisten, en leerling-verpleegkundigen, over de vraag of hoofdverpleegkundigen voldoende op de hoogte zijn van hun werkbeoordeling. Directe superieuren en specialisten zijn van mening dat zij de hoofdverpleegkundigen beter op de hoogte houden dan de hoofdverplleegkundigen zelf ervaren. Bij leerling-verpleegkundigen is dit juist andersom; die zijn méér dan hoofdverpleegkundigen van mening het afdelingshoofd onvoldoende feed-back te geven over hun werk prestaties.

De informatie over het "hoe" blijkt dus in veel gevallen niet alleen onvoldoende 
over te komen "ook de mate watin die informatie overkomt wordt verschillend beoordeeld.

Er blijken verschillende inzichten te bestaan tussen zowel hoofdverpleegkundigen en directe superieuren, alsook tussen hoofdverpleegkundigen en specialisten over hun onderlinge spanningen. Hoofdverpleegkundigen onderschatten hun spanningen met directe superieuren en overschatten die met specialisten (volgens het standpunt van role-senders).

Significant verschillende inzichten constateren wij ook tussen enerzijds hoofdverpleegkundigen en anderzijds gediplomeerden en leerlingen als de onderlinge verstandhouding ter sprake komt. Hoofdverpleegkundigen overschatten hun verstandhouding met gediplomeerden en leerlingen (volgens het standpunt van role-senders).

Er bestaat gezamenlijke rolonduidelijkheid tussen hoofdverpleegkundigen en role-senders. Dit komt vooral tot uiting in de onbekendheid met de werkbeoordeling.

Bij gezamenlijke rolonduidelijkheid zien wij twee clusters rondom de hoofdverpleegkundigen. Het eerste bestaat uit directe superieuren en specialisten, het tweede uit gediplomeerden en leerling-verpleegkundigen. Directe superieuren en specialisten zijn het in veel gevallen met elkaar eens, evenals gediplomeerden en leerling-verpleegkundigen.

De - vaak negatieve-correlaties tussen de meningen van de clusters zijn van dien aard dat wij niet zozeer van onderlinge eensgezindheid tussen alle role-senders op de afdeling kunnen spreken. Gezamenlijke rolonduidelijkheid van hoofdverpleegkundigen kunnen wij daarom niet primair toeschrijven aan het falen van hun perceptie.

3. Het derde belangrijke punt van dit onderzoek achten wij het verband dat wij vonden tussen ervaren rolonduidelijkheid van hoofdverpleegkundigen en het door hen als minder gunstig ervaren gedrag van role-senders. Vooral de gedragingen van directe superieuren dienen in dit opzicht te worden genoemd. Het blijkt dat de meningen van role-senders over hun gedrag niet correleren met de ervaringen omtrent dat gedrag van de hoofdverpleegkundigen. Wij vonden een zekere mate van onbegrip tussen hoofdverpleegkundigen en role-senders. Opvallend zijn in dit verband de meningen van hoofdverpleegkundigen en leerlingen. Bij ervaren rolonduidelijkheid van hoofdverpleegkundigen zijn de leerlingen juist van mening dat zij de hoofdverpleegkundigen goed op de hoogte houden van hun werkbeoordeling en dat hoofdverpleegkundigen juist gemakkelijk aan hun verwachtingen kunnen voldoen.

\section{Hoofdsiuk 7}

4. Uit de analyse blijkt dat de institutionele context geen effect heeft op de ervaren rol(on)duidelijkheid: ziekenhuisgrootte, type afdeling, noch regio houden verband met de ervaren rol(on)duidelijkheid van hoofdverpleegkundigen. 
5. Wij onderzochten welke reacties hoofdverpleegkundigen tonen op ervaren rolonduidelijkheid. Naarmate de ervaren rolonduidelijkheid van hoofdverpleegkundigen groter is, blijkt de ervaren verantwoordelijkheid voor anderen geringer te zijn.

Wij constateerden positieve verbanden tussen enerzijds ervaren rolonduidelijkheid van hoofdverpleegkundigen en anderzijds hun mening te weinig gebruik te kunnen maken van bun kennis en bekwaamheden, rolconflicten, gebrek aan sociale ondersteuning door directe chef en collega's, toekomstonzekerheid, gezondheidsklachten, klachten over hun psychische conditie, verlies van zellwaardering en bezorgdheid over eigen functioneren.

\section{Hoofdstuk 8}

6. In de tweede helft van de studie gingen wij de conditionerende effecten na van enkele variabelen op de relaties tussen ervaren rolonduidelijkheid en enkele andere stressoren en strains.

Wij selecteerden rigiditeit voor nadere bestudering, omdat in de onderzoeksliteratuur verbanden worden gevonden tussen rigiditeit van een functionaris en de ervaren rolduidelijkheid.

Onze analyse bevestigde dit: rigide hoofdverpleegkundigen ervaren significant méér rolduidelijkheid dan flexibele afdelingshoofden.

7. Als thoofdverpleegkundigen eenmaal rolonduidelijkheid ervaren, vinden wij dan binnen de groep rigide afdelingshoofden méér of minder negatieve reacties daarop dan binnen de groep flexibele hoofdverpleegkundigen?

Rigide afdelingshoofden blijken op ervaren rolonduidelijkheid meer met rolconflicten te reageren dan flexibele hoofdverpleegkundigen, maar de laatstgenoemden reageren op ervaren rolonduidelijkheid meer met gezondheidsklachten.

\section{Hoofdstuk 9}

8. In de literatuurstudie en onderzoeksbevindingen komt herhaaldelijk de opvatting naar woren dat ervaren rolonduidel ijk heid samenhangt met minder gunstige intermenselijke verhoudingen. Daarom gingen wij na welke conditionerende effecten intermenselijke verhoudingen hebben op de relatie tussen ervaren rolonduidelijk heid en andere stressoren en strains.

In eerste instantie baseren wij het oordeel over gunstige/minder gunstige intermenselijke verhoudingen op de visie van role-senders; in tweede instantie op de percepties van hoofdverpleegkundigen.

Bij eerdere analyse hebben wij twee clusters rondom de hoofdverpleegkundigen ontdekt: directe superieuren tezamen met specialisten en gediplomeerden tezamen met leerlingverpleegkundigen. Daarom baseren wij ons thans op voornoemde twee clusters.

Uit de onderzoeksbevindingen blijkt dat bij gunstige intermenselijke verhoudingen (zoals waargenomen zowel door directe superieuren en specialisten, alsook door gediplomeerden en leerling-verpleegkundigen) de relatie wordt 
versterkt tussen ervaren rolonduidelijkheid en de mening van hoofdverpleegkundigen dat zij onvoldoende gebruik kunnen maken van hun kennis en bekwaamheden. Wij denken dit te kunnen verklaren door te wijzen op de tijdabsorberende bemoeien is van hoofdverpleegkundigen bij het handhaven van een goed werkklimaat. Hun (kennelijk succesvolle) pogingen laten hen niet veel tijd over voor het ontplooien van verpleegkundige kennis en waardigheden. Bij minder gunstige intermenselijke verhoudingen (waargenomen door directe superieuren en specialisten) wordt de relatie versterkt tussen ervaren rolonduidelijkheid van hoofdverpleegkundigen en hun gezondheidsklachten.

Bij gunstige intermenselijke verhoudingen (waargenomen door gediplomeerden en leerlingen) wordt de relatie versterkt tussen ervaren rolonduidelijkheid van hoofdverpleegkundigen en het afnemen van hun zelfwaardering. Bij deze, op het eerste gezicht wonderlijke, uitslag dienen wij erop te wijzen dat de gunstige relatie met het afdelingshoofd een perceptie is van gediplomeerden en leerlingen. Jonge mensen uiten vriendschappelijke gevoelens niet zelden opeen wijze die door ouderen niet altijd als vriendelijk wordt ervaren.

9. Als wij vanuit het standpunt van hoofdverpleegkundigen kijken naar gunstige/ minder gunstige intermenselijke verhoudingen, wat constateren wij dan?

Er blijken significante verbanden te bestaan tussen enerzijds ervaren rolonduidelijkheid van hoofdverpleegkundigen en anderzijds minder gunstige sociale ondersteuning door directe superieuren en minder gunstige sociale ondersteuning door collega's.

10. Het laatste onderzoekspunt houdt zich bezig met het verschil in reactie op ervaren rolonduidelijkheid tussen hoofdverpleegkundigen die gunstige en die minder gunstige intermenselijke verhoudingen rapporteren.

Uit deze analyse komt naar voren dat bij gunstige/minder gunstige sociale ondersteuning door directe superieuren de reacties op ervaren rolonduidelijkheid niet significant van elkaar verschillen.

$\mathrm{Bij}$ gunstige/minder gunstige sociale ondersteuning door collega's op de afdeling zien we echter wel significant andere reacties opervaren rolonduidelijkheid. Zo blijkt bij minder gunstige sociale ondersteuning het volgende: hoofdverpleegkundigen ervaren dan minder verantwoordelijkheid woor anderen, zij zeggen minder gebruik te kunnen maken van hun kennis en bekwaamheden, hebben een grotere bezorgdheid ten aanzien van hun eigen functioneren en hebben meer verlies van zelfwaardering.

\section{Hypothesen}

In hoofdstuk 4 formuleren wij 28 hypothesen, waarvan 13 niet en 15 wel werden bevestigd. 
Niet bevestigde hypothesen

Hypothese- Hypothesebeschrijving

nummer

3

Er bestaat een negatieve relatie tussen gezamenlijke taakduidelijkheid en ervaren rolonduidelijkheid van hoofdverpleegkundigen.

4

Er bestaat een positieve relatie tussen minder verantwoordelijkheid voor anderen dragen en ervaren rolonduidelijkheid van hoofdverpleegkundigen.

Er bestaat een positieve relatie tussen werkoverbelasting van hoofdverpleegkundigen en hun ervaren rolonduidelijkheid.

Er bestaat een positieve relatie tussen de mening van hoofdverpleegkundigen dat zij te weinig participeren in de besluitvorming en de ervaren rolonduidelijkheid van hen.

10

15

17

18

Er bestaat een positieve relatie tussen arbeidsontevredenheid van hoofdverpleegkundigen en hun ervaren rolonduidelijkheid.

5 Er bestaat een positieve relatie tussen ziekteverzuim van hoofdverpleegkundigen en hun ervaren rolonduidelijkheid.

7 Er bestaat een positieve relatie tussen de wens van hoofdverpleegkundigen om een andere baan te zoeken en hun ervaren rolonduidelijkheid.

8 Er bestaat een positieve relatie tussen de wens van hoofdverpleegkundigen om eerder dan gebruikelijk met pensioen te gaan en hun ervaren rolonduidelijkheid.

Er bestaat een positieve relatie tussen de leeftijd (ouder) van hoofdverpleegkundigen en hun ervaren rolonduidelijkheid.

1 Er bestaat een positieve relatie tussen het geslacht van hoofdverpleegkundigen (man) en hun ervaren rolonduidelijkheid.

2 Er bestaat een positieve relatie tussen de burgerlijke staat van hoofdverpleegkundigen (zonder partner) en hun ervaren rolonduidelijkheid.

5 Er bestaat een positieve relatie tussen een gebrek aan sociale ondersteuning van hoofdverpleegkundigen door anderen op het werk en de ervaren rolonduidelijkheid van hoofdverpleegkundigen.

Er bestaat een positieve relatie tussen een gebrek aan sociale ondersteuning van hoofdverpleegkundigen door verwanten en kennissenen de ervaren rolonduidelijkheid van hoofdverpleegkundigen.

\section{Bevestigde hypothesen}

6

Er bestaat een positieve relatie tussen de mening van hoofdverpleegkundigen dat zijonvoldoende gebruik kunnen maken van hun kennis en bekwaamheden en hun ervaren rolonduidelijkheid.

Er bestaat een positieve relatie tussen de rolconflicten van hooldverpleegkundigen en hun ervaren rolonduidelijkheid.

Er bestaat een positieve relatie tussen de toekomstonzekerheid van hoofdverpleegkundigen en hun ervaren rolonduidelijkheid. 
Er bestaat een positieve relatie tussen de gezondheidsklachten van hoofdwerpleegkundigen en hun ervaren rolonduidelijkheid.

2 Er bestaat een positieve relatie tussen de psychische klachten van hoofdverpleegkundigen en hun ervaren rolonduidelijkheid.
Er bestaat een positieve relatie tussen het verlies aan zelfwaardering van hoofdverpleegkundigen en hun ervaren rolonduidelijkheid.

4 Er bestaat een positieve relatie tussen de bezorgdheid van hoofdverpleegkundigen over hun eigen functioneren en hun ervaren rolonduidelijkheid.

Er bestaat een significant verschil in de ervaren en gewenste rolondui-
delijkheid van hoofdverpleegkundigen.
Er bestaat een negatieve relatie tussen de rigiditeit van hoofdverpleeg- kundigen en hun ervaren rolonduidelijkheid.

3 Er bestaat een positieve relatie tussen een gebrek aan sociale ondersteuning van hoofdverpleegkundigen door hun directe superieuren en de ervaren rolonduidelijkheid van hoofdverpleegkundigen.
Er bestaat een positieve relatie tussen een gebrek aan sociale onder- steuning van hoofdverpleegkundigen door hun collega's op het werk en de ervaren rolonduidelijkheid van hoofdverpleegkundigen.

Er bestaat een positieve relatie tussen een minder gunstige verstandhouding van hoofdverpleegkundigen met hun directe superieuren en de ervaren rolonduidelijkheid van hoofdverpleegkundigen.

28 Er bestaat een positieve relatie tussen spanningen van hoofdverpleegkundigen met hun directe superieuren en de ervaren rolonduidelijk-

heid van hoofdverpleegkundigen.
Er bestaat een positieve relatie tussen de mening van hoofdverpleegkundigen dat zij moeilijk kunnen beantwoorden aan de verwachtingen van directe superieuren en specialisten en de ervaren rolonduidelijkheid van hoofdverpleegkundigen.

Er bestaat een positieve relatie tussen de mening van hoofdverpleegkundigen dat directe superieuren, specialisten en leerling-verpleegkundigen hen onvoldoende op de hoogte brengen van hun werkbeoordeling en de ervaren rolonduidelijkheid van hoofdverpleegkundigen.

\section{Slotbeschouwing}

Het onderzoek naar de ervaren rolonduidelijkheid van hoofdverpleegkundigen schetst een situatie waarin stress en problemen centraal staan. Wij dienen ons echter te realiseren dat deze studie een onderdeel is van een groter geheel waarin ook veel positieve facetten naar woren komen. Enkele daarvan beschreven wij reeds in een voorafgaand rapport (Van den Bergh-Braam 1982) waarvan wij sommige willen aanhalen. 
Uit thet onderzoek blijkt dat afdelingshoofden veel arbeidssatisfactie beleven; 50 procent zegt tamelijk veel voldoening in het werk te ervaren en 45 procent spreekt zelfs van zeer veel voldoening. Uit een soortgelijk onderzoek bij hoofdverpleegkundigen in Engelse ziekenhuizen (Redfern 1981) komen exact dezellde gegevens naar voren.

De motivatie van hoofdverpleegkundigen is groot: 72 procent zegt dat het werk voor hen een levensvervulling is; zij willen veel voor anderen betekenen. 18 Procent zegt dat de patiëntenzorg hen aantrekt en 13 procent vindt voldoening in het werk vanwege de grote mate van zelfstandigheid die de functie hen toestaat. Alle rolesetleden zeggen dat hoofdverpleegkundigen diegenen zijn die de meeste invloed op de ziekenafdeling hebben en dat dit zo dient te blijven.

De role-senders hebben veel respect voor de hoofdverpleegkundigen; op veel punten schatten zij de hoofdverpleegkundigen hoger dan deze zelf aangeven. Vooral de achting van specialisten voor hoofdverpleegkundigen komt opvallend vaak naar voren. Volgens role-senders ligt de sterke kant van het afdelingshoofd in haar omgang met patiënten. Daarom vinden velen haar als rolmodel voor leerlingen zeer geschikt.

Het is niet ondenkbaar dat de positieve kanten van het werk de negatieve compenseren en dat de momentopnamen, die wij in de voorafgaande hoofdstukken vastlegden, in een groter verband het navrante karakter verliezen.

Ondanks deze overwegingen, die wijgraag willen plaatsen om eenzijdige belichting te voorkomen, willen wij, mede door eigen verpleegkundige ervaring, pleiten voor het bevorderen van meer rolduidelijkheid van (hoofd) verpleegkundigen.

Maastricht, mei 1984

A.H.M. van den Bergh-Braam. 



\section{Chapter 10}

\section{Summary and discussion}

The survey was set up to study the problems experienced by headnurses in the execution of their function. Headnurses are considered as keyfigures on the ward. By a survey on stress of headnurses we wished to create a basis for measures to improve nursing care.

30 Hospitals participated in the survey. The sample at random was stratified on size of hospital, ward type and region. We used the so-called role-set approach. Here the headnurse is the central point. As role-senders are acting: immediate superiors, consultants, registered nurses and student-nurses.

The number of replies were 600,120 of each group. The survey is based on the stressmodel adopted from Kahn (1964) and French and Caplan (1972).

In the pilot study the first data were worked in two reports (van den Bergh-Braam 1982, 1983). From the findings presented in these reports, workoverload and role-ambiguity proved to be two important sources of stress for headnurses.

We wished to study further one of these two problems. As role-ambiguity can be measured less subjectively than workoverload, we chose a further analysis of the role-ambiguity of headnurses as central theme for this dissertation also because of the framework of our survey.

\section{Limitations}

Out of the whole of the data - because of the refusal of cooperation of one hospital and incomplete or non-availability of response from a number of role-sets - in the end 81 role-sets remained. Because of the selection, relatively more role-sets from bigger hospitals prove to remain outside the survey than those from the smaller and medium-sized institutes. When summarizing findings of the survey we should therefore exercise some caution as to hospitals from "function classification 4 " and university clinics. However, the selection has not changed the numerical relations between type of ward and region. The survey is subject to some more limitations, for example the composition of the role-set not being as extensive as we wished. Important groups, for example physiotherapists, laboratory chemists, welfarepersonnel, secretaries and kitchen-assistants have not been questioned. We would have liked to have at least one of these groups included in the survey. As we could not reach agreement with the hospital managements on the question of which group would be eligible, we had to give up this intention. For practical and organizational reasons the views of patients are not given in this survey. 
We regret that we could not correlate the expectations of patients with the task perceptions and experienced role-clarity or ambiguity of headnurses. Further the survey only refers to the worksituation. Other sectors such as family life and corporate life are left out of consideration. We asked for the social support of the partner but as 63 percent of the heads of wards claim to live alone, we could not maintain this variable in the analysis. We realize that this can be an important limitation to explain the differences in strains.

As we could not execute factor-analyses on the task/contact conceptions of headnurses, that part of the survey has been limited to record conceptions of rolesenders whereas we would have preferred to compare expectations between headnurses and role-senders.

Although we have inquired fully in questionnaires about various forms of nursing and their influence upon the function of headnurses, the replies proved to be of such a nature that we could not use them for further analyses. Especially the small number of respondents claiming to practise another form than functional nursing, made meaningful inclusion of this variable impossible. However, we realize well that as since 1980 teamnursing has been increasing, role-ambiguity of headnurses can be greater than emerges from this survey. The same applies to problems connected with closing or merging of hospitals after which we inquired, but the number of concrete replies was too small.

The scales trying to measure social support from: immediate chief, colleagues, others at the work and relatives/friends, seem to do this on a rough scale; they measure rather potentially available than actually mobilized social support.

We also wish to point out the subjective bias that can distort particularly the data on sick absenteeism. We received these data from the respondents themselves and not from the hospital administration. Empiric data learn that figures given by organizations are more reliable than information given by those concerned.

Finally we wish to point out that the analyses were executed on data collected at one point of time (cross-sectional design). This type of survey does not lend itself for comparison with causal relations. The interpretations given by us sometimes, should therefore not be considered as a cause/effect relation but as possible explanations.

\section{Summary findings}

Wo want to present the main findings of this survey as replies to the ten survey-questions from chapter 3 . Numbers below refer to the corresponding numbers in that chapter.

\section{Chapter 5}

1. One of the most important findings of the survey is that joint task-clarity between headnurses and role-senders does not lead to experienced role-clarity of headnurses; sometimes we even observe the contrary.

When headnurses and role-senders agree on the live most important tasks of headnurses (which could be for example to attend the patient, to coordinate work, to organize adequate staffing, to maintain an agreeable sphere of activi- 
ty and to accompany the doctors' visits) it means a sign of joint clarity of task. The headnurse knows very well "what" she has to do but not yet "how": she experiences role-ambiguity with joint clarity of task. Ditrerent methods of treatment, visions on patient management, opinions on collaborationstrategies, allocations of staff and divergent interests and motivations determine among other things the expectations with regard to the role-behaviour of headnurses. These divergent behaviours and expectations hardly crystallize to a clearly described expectation pattern offering some hold to headnurses. We even presume that some groups conceal their motivations and aspirations. The underground drifts thus created and informal wields of power, limit a clear insight of headnurses. Probably this tendency will rather increase than decrease by the future developments in the hospital. We thereby think of the uncertainties on new budgeting-systems, increasing reduction of beds, faster flow of patients, reduction of nursing staff, threatening of unemployment and greater chill of the hospital atmosphere.

Hospital managers wishing to fight that role-ambiguity of headnurses cannot content themselves with mere task-technical instructions.

\section{Chapter 6}

2. As second important point of this study we mention the deviating insights between headnurses and role-senders on their mutual understanding, tensions, expectations and work-appreciation (joint role-ambiguity).

There are significant differences between headnurses on the one side and on the other side immediate superiors, consultants and student-nurses on the question of whether headnurses are sufficiently acquainted with their workappreciation. Immediate superiors and consultants are of the opinion that they keep the headnurses better posted than the headnurses experience themselves.

With student-nurses this is the other way round; they are - more than headnurses - the opinion that they give insufficient feed-back about their work achievements to the head of the ward.

The information on the "how" does not only prove to come through insulficiently but its extent to come through is also considered differently.

Different views prove to exist between headnurses and their immediate superiors as well as between headnurses and consultants about their mutual strains. Headnurses underestimate their strains with immediate superiors and overestimate those with consultants (according to the point of view of rolesenders). We also recorded significantly different views between on the onc side headnurses and on the other side registered and student-nurses if mutual relationship comes up. Headnurses overestimate their understanding with registered and student-nurses (according to the point of view of rolesendersi.

Joint role-ambiguity exists between headnurses and role-senders. This is especially ventilated in the unacquaintance of the work-appreciation.

With joint role-ambiguity we see two clusters around the headnurses. The first 
one exists of immediate superiors and consultants, the second one of registered nurses and student-nurses. Immediate superiors and consultants are in agreernent with each other in many cases, as are registered nurses and studentnurses.

The - often negative - correlations between the opinions of the clusters are of such a nature that we cannot speak about so much as mutual unanimity between all role-senders on the ward. Joint role-ambiguity of headnurses cannot therefore be credited primarily to the failure of their perception.

3. The third important point of this survey is found to be the relation we recorded between experienced role-ambiguity of headnurses and the behaviour of rolesenders experienced by them as less favourable. Especially the behaviours of immediate superiors should be mentioned in this respect. Views of role-senders about their behaviour do not prove to correlate with the experience of that behaviour of the headnurses. We found a certain degree of incomprehension between headnurses and role-senders. Notably in this respect are the views of headnurses and student-nurses. With experienced role-ambiguity of headnurses, the student-nurses are only of the opinion that they keep the headnurses well informed of their work-appreciation and that headnurses can only meet with their expectations easily.

\section{Chapter 7}

4. From the analysis it appears that the institutional context has no effect on the experienced role-clarity/ambiguity: neither size of hospital, type of ward nor region are connected with the experienced role-clarity/ambiguity.

5. We examined reactions shown by headnurses on experienced role-ambiguity. Accordingly as the experienced role-ambiguity of headnurses is greater, the experienced responsability for others proves to be more remote. We found positive connections between on the one side experienced role-ambiguity of headnurses and on the other side their view not to be able to use sufficiently their knowledge and skill, role-conflicts, lack of social support by immediate chief and colleagues, uncertainty about the future, health complaints, complaints about their psychic condition, loss of self-esteem and anxiety on their own functioning.

\section{Chapler 8}

6. In the second half of the study we checked the conditioning effects of some variables on the relations between experienced role-ambiguity and some other stressors and strains.

We selected rigidity for further study because connections are found in the research literature between rigidity of a functionary and the experienced roleclarity. Our analysis confirmed this: rigid headnurses experience significantly more role-clarity than flexible heads of wards. 
7. Once headnurses experience role-ambiguity do we than find within the group. rigid heads of wards more or less negative reactions on it than within the group of flexible headnurses?

Rigid heads of wards prove to react on experienced role-ambiguity more with role-conflicts than flexible headnurses do, but the last react (on experienced roleambiguity) more with health complaints.

\section{Chapter 9}

8. In the literary study and research findings repeatedly the view comes to the fore that experienced role-ambiguity is connected with less favourable interhuman relations. We therefore examined which conditioning effects interhuman relations have on the relation between experienced role-ambiguity and other stressors and strains.

In the first instance we base the judgment of favourable/less favourable interhuman relations on the vision of role-senders; in the second instance on the perceptions of headnurses.

With earlier analysis we discovered two clusters around the headnurses: immediate superiors together with consultants and registered nurses together with student-nurses. That is why we now ground ourselves on above-mentioned two clusters.

From the research findings it appears that with favourable interhuman relations (such as observed both by immediate superiors and consultants as well as by registered nurses and student-nurses) the relation between experienced roleambiguity and the opinion of headnurses is strengthened that they can make insufficient use of their knowledge and skill. We think we can explain this by pointing out the time-absorbing exertion of headnurses to maintain a good working climate. Their (apparently successful) efforts do not leave them much time to develop nursing knowledge and skill.

With less favourable interhuman relations (observed by immediate superiors and consultants) the relation between experienced role-ambiguity of headnurses and their health complaints is strengthened.

With favourable interhuman relations (observed by registered nurses and student-nurses) the relation between experienced role-ambiguity of headnurses and the decrease of their self-esteem is strengthened.

With this result, surprising at first sight, we should point out that the favourable relation with the head of ward is a perception of registered nurses and studentnurses. Young people of ten express their friendly feelings in a way which is not always experienced as friendly by older people.

9. If we look at favourable/less favourable interhuman relations from the point of view of headnurses, what do we observe?

Significant connections prove to exist bet ween on the one side experienced rolea mbiguity of headnurses and on the other side less fa vourable social support by immediate superiors and less favourable social support by colleagues. 
- last point of research concerns the difference in reaction on experienced rolebiguity between headnurses reporting favourable and those reporting less ourable interhuman relations. From this analysis it comes to the fore that h favourable/less favourable social support by immediate superiors, the ctions on experienced role-ambiguity are not significantly different.

wever, with favourable/less favourable social support by colleagues on the id we see signilicantly other reactions on experienced role-a mbiguity. So the owing appears with less favourable social support: headnurses experience i responsibility for others, they say they can make less use of their knowledge I skill, are more concerned about their own functioning and have more loss of -esteem.

eses

ter 4 we formulated 28 hypotheses, out of which 13 were not confirmed and 15

\section{firmed hypotheses}

$r$ of Description of hypothesis

esis

There exists a negative relation between joint task clarity and experienced role-ambiguity of headnurses.

There is a positive relation between bearing less responsibility for others and experienced role-ambiguity of headnurses.

There exists a positive relation between workoverload of headnurses and their experienced role-ambiguity.

There is a positive relation between the opinion of headnurses that they participate too little in the process of decision and their roleambiguity experienced.

There is a positive relation between workdissatisfaction of headnurses and their experienced role-ambiguity.

There is a positive relation between sick-absenteeism of headnurses and their experienced role-ambiguity.

There is a positive relation between headnurses wishing to look for another job and their experienced role-ambiguity.

There is a positive relation between the wish of headnurses to retire earlier than usual and their experienced role-ambiguity.

There is a positive relation between the age (older) of headnurses and their experienced role-ambiguity.

There is a positive relation between the sex of headnurses (male) and their experienced role-ambiguity.

There is a positive relation between the civil status of headnurses (without partner) and their experienced role-ambiguity.

There is a positive relation between a lack of social support of headnurses by others at work and the experienced role-ambiguity of headnurses. 
There is a positive relation between a lack of support of headnurses by relatives and acquaintances and the experienced role-ambiguity of headnurses.

\section{Confirmed hypotheses}

6

8

9

II

12

There is a positive relation between the opinion of headnurses that they can use insufficiently their knowledge and skill and their experienced role-ambiguity.

There is a positive relation between the role-conflicts of headnurses and their experienced role-ambiguity.

There is a positive relation between the uncertainty about the future of headnurses and their experienced role-ambiguity.

There is a positive relation between health complaints of headnurses and their experienced role-ambiguity.

There is a positive relation between the psychic complaints of headnurses and their experienced role-ambiguity.

There is a positive relation between the loss of self-esteem of headnurses and their experienced role-ambiguity.

There is a positive relation between the concern of headnurses on their own functioning and their experienced role-ambiguity.

There is a significant difference in the experienced and desired roleambiguity of headnurses.

There is a negative relation between the rigidity of headnurses and their experienced role-ambiguity.

3 There is a positive relation between a lack of social support of headnurses by their immediate superiors and the experienced roleambiguity of headnurses.

There is a positive relation between a lack of social support of headnurses by their colleagues at work and the experienced rolleambiguity of headnurses.

There is a positive relation between a less favourable understanding of headnurses with their immediate superiors and the experienced roleambiguity of headnurses.

There is a positive relation between tensions of headnurses with their immediate superiors and the experienced role-ambiguity of headnurses.

There is a positive relation between the opinion of headnurses that it is hard for them to come up to the expectations of immediate superiors and consultants and the experienced role-ambiguity of headnurses. There is a positive relation between the opinion of headnurses that immediate superiors, consultants and student-nurses inform them insufficiently of their work-appreciation and the experienced roleambiguity of headnurses. 


\section{Concluding observations}

The survey of the experienced role-ambiguity of headnurses outlines a situation focused on stress and problems. However, we should realize that this study is part of a greater whole where also many positive aspects come forward. Some of them were already described by us in a previous report (van den Bergh-Braam 1982) some of which we wish to quote.

From the survey it appears that heads of wards enjoy much work-satisfaction. 50 percent say to experience rather much satisfaction in their work and 45 percent even speak about very much satisfaction. From a similar survey with headnurses in English hospitals (Rediern 1981) exactly the same data came forward.

The motivation of headnurses is great: 72 percent say that the work is a lifefulfillment for them; they wish to mean much for others. 18 percent say that they are attracted by patient care and 13 percent find satisfaction in the work because of the high degree of independence the function allows them. All role-set-members say that headnurses are those having most influence on the ward and that this should be maintained.

The role-senders have much respect for headnurses; in many aspects they esteem the headnurses higher than indicated by themselves. Especially the esteem of consulting physicians strikes as often coming forward. According to the role-senders the strong side of the head of the ward lies in her relationships with patients. That is why many consider her very suitable as a role-model for student-nurses.

It is not inconceivable that the positive sides of the work compensate the negative ones and that the snapshots we recorded in the previous chapters loose their distressing character in a greater whole. In spite of these considerations that we like to make to prevent one-sided exposure, also because of our own nursing experience, we want to plea for the promotion of more role-clarity of (head)nurses. 


\section{Literatuuropgave}

Abdellath, F. ea. Patieni centered approaches to nursing. New York: the MacMilan Company 1960.

All, C.J. Het ziekenhuis: een plan voor verandering. Deventer: Van Loghum Slaterus 1977.

American Nurses" Association. Commission in Nursing Services. Roles, responsibilities andqualufications on mursing administration. New York: ANA 1978.

Ampe, A. Invloed van het bureaucratisch karakter van het ziekenhuis op het medisch en verpleegkundig beroep. Acta Haspitalia $1970,2,152-177$.

Baker, W. G. Changes in life goals as related to success in a nursing leadership role. Nursing research 1979 , $28,4,234-236$

Bales, R.F. Interaction process analysis: a methodfor ihe sudy of smallgroups. Cambridge, Massachusetts: Addison-Wesley Publishing Company, Inc. 1953.

Batint, H. De dokter, de patiën, de ziehte. Utrecht/Antwerpen: Uitgeverij Het Spectrum, 1972.

Barness, E. Mensen in het ziekenhuis. Utrecht: Het Spectrum 1967.

Bastelaer, A. van en Beers, W. van. Vragenlijst Organisatrestress (VOS): psychometrische kanttekeningen bij wergelijking van data over vijf onderzoeksgroepen. Nijmegen: Katholieke Universiteit, Stressgroep Nijmegen 1980 .

Bastelaer, A. vanen Beers, W. van. Organisathestressende personeelfunktonaris. Lisse: Swetsen Zeinlinger B.V. 1982.

Baumgart, A.J. Nursing for a new century: a future frame-work. International Nursing Review 1981, 28 (239) $5,139-153$.

Benoliel, J. Nurse-physician perceptions of i.c.u. nurses" role. American Journal of Nursing 1979, $5,917$. Bergh-Braam. A.H.M. van den Het rolconflict van de hoofdverplegkundige Intern rapport 78 AO 02. Publicatie no. 4 Stressgroep Nijmegen. Katholicke Universiteit Nijinegen 1978.

Bergh-Braam, A.H.M van den Stress bijhoofdverpleegkundigen. Interim-rapport. Intern rapport 80 AO 22. Publicatie no. 18 Stressgroep Nijmegen. Katholieke Universiteit Nijmegen 1980.

Bergh-Braam, A.H.M. van den De hoofalverpleegkundigen. Een onderzoek naar hun positie en problemen in de Nederlandse ziekenhuizen. Intern rapport 81 AO 03 . Publicatie no. 28 Stressgroep Nijmegen. Katholieke Uniwersiteit Nijmegen 1.981.

Bergman, R. et al. Role selection and preparation of unit head nurses. International Joumal Nursing Srudies $1981,18,2,123-152$.

Bernard, J. and Thompson, L. Sociology. Nurses and patients in a modern society. St. Louis: Mosby Company, 1966.

Berting, J. en Sitter, L.U. de. Arbeidsatisfactie. Amsterdam: Stichting Interuniversitair institutut voor Sociaal Wetenschappelijk Onderzoek (SISWO) 1971.

Boccuzzi. M. Head nurse growth" a priority for the supervisor. American Journal of Narsing 1979, 8, 1389. 1392.

Bremer, J. De ziekenhuispatiën. Utrecht: Dekker en v.d. Vegt N. V. 1964.

Broeders. M. Het belang van intermenselijke kammunikatie en relatie in thet beroep van verplegende. Nijmegen: scriptic K.H.S.V.V. 1972.

Bruyn, $\mathbb{L}$. de. Een gelijkwaardigen(n) relatie met de patient. Tijdschrift voor Ziekemverpleging $1979,32,4$, $149-1154$.

Caldwell, J and Weiner, M. Stresses and coping in I.C.U, nursing, General Hospinal Psychiary 1981, 3 , $119-127$.

Caplan. R.D. Organizational stress and indiwidual strain: a social psychological study of risk factors in coronary heart disease among administrators, engineers and scientists. Ann Arbor: Institute for Social Research, University of Michigan. (Uniwersity Microfilms 72-14822) 1971.

Caplan, R. D. et al. Effects of work $\|$ oad, role ambiguity and type A personality on anxiety, depression and heart rate. Journal of Applied Psychology, 1975,6,60, 713-719.

Cassee, E. Th. Leiderschap en rolbegrenzing in een ziekenhuisonganisatie. Sociologische Grds 1967, 14. Cassee, E. Th. en Lammers, C.J. Mensen in het ziekenhwis. Groningen: Wolters Noordhof, 197 I. 
Cassee, E. Th. en Philipser, H Autoritaire instelling en leiderschap. De conditionerende werking van een personlijkheidskenmerk op de beleving wan het leiderschap door verpleegsters. Sociologische Gids 1968 , 6. 14, 286-298.

Castle dine, $G$. Charge nurse drops bombshell over the future of ward sisters. Nursing Mirror 1977, 29, 8, $241-244$.

Cherps. A Work and Values: shifing patterns in industrial society. Intemorional Sociological Science Journal $1980,32,3,427-441$.

Consumentengids 1978 .

Cobb, S. Social support as a moderator of life stress. Psychosomatic Medicine, 1976, 38, 5, 300-314.

McCormiclk, E.J. Mob analysis methods and applications. New York: AMACOM 1979.

Cornelissen . A. Het rolconflich wan de hoofdherpleegkundige. Nijmegen: K.H.S.V.V. 1974.

Corwin, R. Role conception and mobiliny aspiravion: a study in formation and uransformation of bureaucratic, professional, and humaniarian nursing identites. Minneapolis. University of Minnesota, 1960. Coser. R. The Hospinal in Modern Sociery. Ed. Freidson, E. Chapter 8. Chicago: Adline Atherton 1971. Croniry-Stubbs, D. and Velsor-Friedrich, B. Professional and personalstress: asurwey. Nursingleadership $1981,4,1,19-26$

Dahrendorf, R. Homo sociologicus. Ein Versuch zur Geschichte, Bedeutung und Kritik der Kategorieder Sozialen Rolle. Köln: Westdeutscher Verlag, 1958.

Davis, F. and Olesen, V.L. Baccalaureate students images of nursing. Nursing Research 1964, Jan-Feb. $13,8-15$.

Dekkers, F. Informed consent. Rolterdam: sympositum Erasmus Universiteit 1982. Zie ook NRC 19 febr. 1982.

Doyle, M.C. Egalitarianism in a mental health certer: an experment that failed. Hospital and community psychiary 1977,28,7,521-525.

Driessen, J.G.M. Siressoren, sociale stewn en strains. Nijmegerr: publicatie no. 13 Stressgrocp. Katholieke Universiteit Nijmexen 1979.

Dijkhuizen, N. van en Reiche, H.M.J.K.I. Het meten van arganisatiestress: over de bewerking van een wragenlijst. Leiden: Instituut voor Arbeids-en Organisatiepsychologie der Rijksuniversite te Leiden 1979. Dijkhuizen, N. van. From stressors to strains. Lisse: Swets en Zeitlinger B. V. 1980.

Emanuel-Vink, H. Lebers, L. en Heyendaal, P. Het ontslag van patiënten uit het ziekenhuis. Medisch Contact 1981, 46, 1425-1428.

Enk, T, wan. Mari wat verwacht U woor dit bedrag? Tijdschrift woor Ziekenverpleging 1979, 32, 16, 737-740. Enquête studenten hoger onderwijs Friesland te Leeuwarden en werkgroepgezondheidszorg Smallingerland. Onderzoek werkgroep. Patrenten wak slech te sprekenover arts. Leeuwarder Courant, 22 febr. 1982. Everly, G. et al, Perceived dimensions of job saltisfaction for staff registered nurses. Nursing Research 1976. $25,5,346-348$.

Fagin, M. Nurses' rights. American Journal of Nursing 1975, 4, 316-322.

Folk-Lighty, M. and Brennan, A.M.W. Role perception of the staff nurse in the intensive care unit. Heart and Lung $1979,8,3,535-539$.

Ford, L. Teaching hospitals build models for nursing organization. Hospitals 1982, 1, 61, 180-183.

Fontler, H. Gibson, G. and Pinchoff, D. Physician resistance to manpower innovation: the case of the nurse practitioner. Sockal sciance Quaterly 1980,61. 149-157.

Freidson, E. Protessiona Domwance: Ihe social struct ure of medical care. New York: Atherton Press 1970 French, J. and Caplan, R. Organizational stress and individual surain. In: The failure of success. A.J. Matrow (cd.) New York: Amacon 1972, 30-66.

Fry, L.W. and Greenveld, S. An examination of anitudinat differences between policewomenand policemen. Aow wat of applied psychology 1980, 65, 1, 123-126.

Gallung, . Thery and methods of social resedrch. London. George Allen and Unwin Lid. 1970.

Geiger, J in: Homamizing heahth care. By Howard, J, and Strauss, A. New York: Wiley and Sons 1976. Gerversman. A. De verwachting van de directie ten aanzien van de hoofdverpleegk undige. Ons Ziekenhais Juni 1963.

Gilbertson. D. The ward sister: a suitable case for treatment. International Nursing Review 1977, 24, 108. 113.

Goffman, E. Asylums: essays on the social situation of mental patients and other inmattes. Pelican book.

Doubleday: Anchor books 1963.

Goftman, E. The operating room: a study in role distance. Readings in introductory sociology. Wrong $\mathrm{H}$. and Gracy, H. (ed.) Chapter 10. New York: MacMillan Company 1973.

Gonggrijp. F. Ziekenhuisstaven pikken het niet meer. De Telegraaf: 1982, 3 aprill.

Gray-Toft. P. and Anderson, J.G. Stress among hospital nursing staff: its causes and effects. Sociological Sicrence and Medicine 1981, 15a, 639-647. 
Green, S. Professionalburcaucratic conflick the case of the medical profession in the national health service. The Socrological Review 1975, 121-141.

McGregor, R. Social science in atrsing: application for the improvement of patient care. New York: Russell Sage Foundation, 1960 .

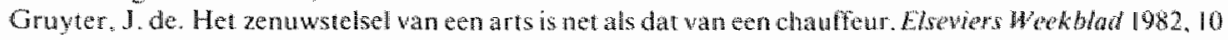
aprit.

Haasse, P. Pathways to practice. American Jownat of Narsing 1976, 76, 5, 215-220.

Habeeb, M. et al. Health care professionals. Role expectations and patient needs. Nursing Resseandt 1977. $26,4,288-298$.

Habenstein, K. and Christ, E. Professionalizer, tradirionafizer and uilizer. An interpretive study of the work of the general duty nurse. Colombia: University ol Missouri, 1955.

Hall, R. Occupations and the social strucrure. Englewood Chils: Prentice Hall 1969.

Hattinga Verschure, J.C.M. Interwiew Algemeen Dagblad 1982, 13 maart.

Hecke, A. van, Wouters, P. Overzicht wan het verloop tijdens de opleiding voor verplecediptoma A. N.Z. I. informatieblad O.W. 51969

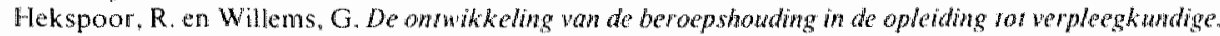
Nigmegen, K.H.S.V. 1978 .

Hermans, F. De middenkaderfunctionaris in de verpleging. Lochem: De Tijdstroom 1977.

Hoekelman, R. Nursemphsician relationship. American Journal of Nursing. 1975, 8, 7, 230-234.

Howard, J. and Strauss, A. Humanizing healh care. New York: Wiley and Sons 1976.

Jacobi, E.H. The moral leadership of the nursing profession Joumat of Advarced Nursing 1977.2.561-569. Jong, J. de. We zijn als super-individualistische genezerik ken opgeleid. De Uitkijk 1982, Maart.

Kahn, R.L. et al. Organizational stress: sfudies in rolemconflict and ambigutry. New York: Wiley and Sons 1964.

Kahn, R.L. French, J.R.P. and Cobb, S. Human refavions and modern managentem. Amsterdam: North Holland Publishing Co. 1974.

Kahn. R.L. Aging and social support. Paper presented at the 1978 anmul meeting of the American Association for the advancement of science. Ann Arbor: Universily of Michigan 1978.

Kaplan. B.H. Cassell, J.C. and Gore, S. Social suppore and health. Medical Care 1977, 15, 5, 47-54.

Karsemeyer, $M$. Wat is er in de verplegingatan de hand? Tijds hrifrwor Ziestewerpleging 1973,26, 14, 351357.

Katz. F. Nurses. The semi-professionals and their arganizations. Etzioni. A fed.) New York: State University $1967,55-81$.

Katz, D. and Kahn, R.L. The social psychology of organizanions. New York: Wiley and Sons 1978.

Ketnan, A. Effects of type A behaviour, intolerance of ambiguity and locus of control on the relationship between role-stress and work-related outcomes. Jownal of occupational psychology 1979,52,4,277-285.

Kelly. G.A. The psychology of personal constracts. New York: Norton 1955.

Kennedy, R. and Vose, A. Preparing the nurse manager to assurne new accountabilities. Hospitads 1978 , $52,3,330-335$.

Kernaghan, S.G. The nurse shortage. Hospirals 1982, Feb. 1, 53-56.

Koene, G. et al. Integrerende Verplecgkunde: wetenschap en praktijk. Lochen: De Tijdstroom 1980.

Kouwer, B.I. Het spel van de persoonlijkheid. Utrecht: Bijleveld 1963.

Kramer, M. Reality shoch, why nurses leave nursing. St. Lous: Mosby and Company 1974.

Kramer, M. and Schmalenberg. C. Parh to biculurism. Wakefield Mass., Contemponary Publising Co. 1977.

Kroef. C. van den. Arrs en verpleeghundige in het ziekenturs. Leiden: Spluyi, van Mantgem en de Does 1970 .

Lammers, C. Het ziekenthuis als kastemaatschappij. Sociologische Gids 1967, 14, 67-85.

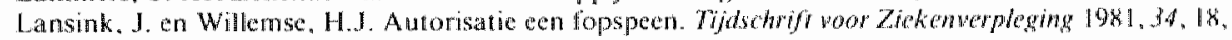
$788-794$.

Leenen, H. Volkskran 1982, 27 maart.

Lem now. P. and Cowdon, P. Human services, professionals and the paradox of institutional reform.

American Joumat of Community 'sychology $1980,8,4,463-483$.

Leshan, Ch. Sysmposium over di' dood. Gehouden te Amsterdam: 1969, 6 jumi.

Linton, R. The study of man. New York: Appleton-Century, 1936.

Liwack, R. in: Wang. R. and Watson. J. (edist. The professional nurse roles, competencies and characteristics. Sipperissor Nusse, 1977, 8.69-71.

LeMaitre, G.A. Physician speaks out on nurses" burnout, American Mounal of Mursing 1981, 8 , 487.

Mallnowski, B. Crime and custom in sawage society. New York: Harcourt, Brace and World, llac. 1926.

Marshall, J. Srress amongs morses. Chaper 2 In: White collar and professional stress ed by Cooper, $C$. and Marshall, J. New York: Wiley and Sons 1980. 


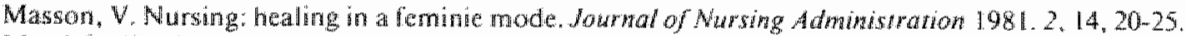
Mead. M.H. Mind, self and saciely. Chicago: University of Chicago Priss 1934.

Merton, R.K. Selected properties of held work in the planned community. American Sociological Rewet $1949,12,304,312$

Mineham, P.L. Nurse role conception. Nursing Researth $1977,26,5,374-379$.

Mintzberg. H. The structuring of organizarons. Englewood Clffs: Prentice-Hall, 1979.

Moreno, J.L. Who shall survive? New York: Beacon, 1934.

Murray, M. Role conflict and intention to leave nursing. Journal of Advanced Nursing 1983,8, 29-31.

Murrell, H. Work stress and menal sitrains a review of some of the literature. Philadelphia: Department of Employment Work Research Unit. Occasional paper no. 6, 1978.

National zekenhuisinstitum. Ziekteverzuin en personetrwerloop in instellingen wan intramurale gezondheidszorg. Utrecht: Informatieblad EC $30,1978$.

National ziekenhusinstitut. Ziekieverzum en personedsverloop in instellingen van intramurale gezondheidszorg. Utrech: Informatieblad 81.241 . 1980.

Nationaal ziekenhuisinstituut. Zickreverzuim en personeelwerloop in instellingen van intramurale gezond heidszorg. Utrecht: Informatieblad $83.334,1982$.

Nic, M. de. In gesprek over spanningsweld wan de hoofdverpleegk undige. Tijdschift voor Ziekenverpleging 1977, 6, 284-285.

Nuyens, Y. Het ziekenhuis als conglomeraat van groepen. Acta Hospiralia 1968, 3, 197-302.

Oberman. W. De attitude-verandering. Tijdschrif' yoor Ziekenverpleging 1972,4, 357.

Pannel1, H. Teaching hospitats build models for nursing organization. Hospitals, 1982, 2, 60-63.

Parsons. T. The social system. New York: Free Priess, 1951.

Parsons, T. and Bales, R.F. The dimensions of acton-space. Working papers in the theory of action. Gilencoe, llinois: The Free Press, 1953.

Parridge, K. Nursing values in a changing society. Nursing Owhook 1978, 356-36\%,

Pay, P. What rewards will keep nurses on the job? American Joumal of Nursing 1975, 3, 214-217.

Perrow, Ch. Complex organizations: a critical essay. Glencoe, lllinois: Foresman 1972.

Pinneau, S. R. jr. Effects of social support on physiatogrical and psychologicalstrains. Ann Arbor University of Michigan (University microfilms no. 76-9491) 1975.

Plachy, K.J. Headnurses: less griping, mote action. Jound of Nursing Adminisration 1976, 6, 1, 39-41. Le Play, F Les Owwers Européens. Paris: Alfred Mame et Fils 1879.

Pool, I.J. Verpleegkunde is miet professioneel. Tijdschrif voor Ziekenverpleging 1978, 31. 21. 953-960. Posner, B.Z. and Randolph, W.A. Perceived situational moderators of the relationship between role ambiguity, job satisfaction and effectiveness. Journal of social psychology 1980, 2, 237-244.

Price, J.L. and Hueller, Ch. W. Professional tumover the case of nurses. New York: S.P. Medical and scientific books, 1981.

Prins, J. Siress in het ziekenhwis: een vergelijkend vooronderzoek bij verpleegkundigen en artsen. Nijmegen: Psychologisch laboratoriurn Katholieke Universiteit 1981.

Redfern, S. Hospital sisters: work attitudes, perceptions and wastage. Jounal of Adranced Nursing $1980,5,451-466$.

Redfern, S. Hospital sisters their job attitudes and occupational stability. London: Royall college of musing 1981

Reiche, H.M.I.K.I. Swess aan het werk. Lisse: Swats en Zeitlinger B.V. 1982.

Rozema "R. en Visser, A. De takk en werkomstandigheden wan praknijkbegeleiders. Amsterdam: Vakgroep Sociale Psychologic, Vrijo Universiteit, 1978

Rotema, R., Visser, A.Ph, en Bockestijn, C. Rolorientatie en rolgedrag in éen brugposirie: een onderzoek onder praktijkbegeleidsters. Dewenter: Van Loghtum Slaterus 1980.

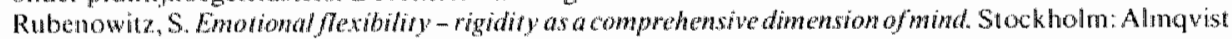
and Wiksell, 1963

Salmon. B. Repon of the comminte on the senior nursing staff structure. (Salmon report) London: Her Majesty Stationary Office 1966.

Sclladee, $\mathrm{G}$, en Pool, J. Observatio op verplecgafdelingen. Amsterdam: Vakgroep Sociale Psychologie. Vrije Universiteit, 1981 .

Sctmalcmberg. C. and Kramer, M. Coping with reality shock. Wakefisld: Nursing resources 1979.

Seluulev" R.S. The elfects of role perceptions on employee satisfaction and performance moderated by employee thility. Organizasional behaviour and haman performance. 1977, 18, 1, 98-107.

Selow, H. en Clay, W. Ziekenhuisverpleegkunde, dreigt er een noodtoestand? Tijdschrift woor Ziekenverpleging $1979,17,789-793$.

Shaw, $M$. and Heymans, B. Constructs of relationships and issues in nursing Jownal of Advanced Norsing $1980,5,187-198$. 
Smith, K. Discrepancies in the value ctimate of nursing students: a comparison of headumses and numse educarors. Stanford: University of Stanford 1964.

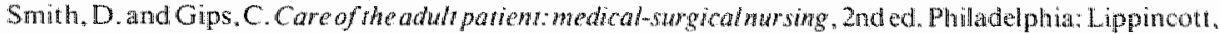
1966.

Spady. W. Dropouts from higher education. Ifterchange. 1970 and 1971 1.2,64-85 and 38-62.

Steverns, B.J. The headnurse as manager. Joumal of Nursing Administration 1974, 4, 2, 36-40.

Stock well. F. The unpopular partent. London: Royal College of Nursingand National Council of Nurses of the United Kingdom, 1972.

Stolte, I. Zieken en hun verzorgers. Groningen: Tjeenk Willink 1976.

Strain. J. Psychological reactions to acute medical illness and critical care. Critical Care Medine 1978,6. 1. 39-44.

Strauss, A. et al. The hospital and its negotiated order. Chapter 5 in: The Hospind in Modern Soctets: Freidson, E. (ed), New York: MacMillan, 1963, 147-169.

Stromberg. M.F. Relationship of sex role identity to occupational image of female nursing students. Nussing Research $1976,25,5,363-369$.

Strwctummota Gezondheidszorg. Statsuitgeverij "s-Gravenhage 1974.

Styles, H.H. Six thousand nurses and the next one hundred years. Intermational Nursing Review $198128,5$. $143-150$.

Tellegen, B. Over rigidireir. Zaltbommel: Avantii 1968.

Terborgh-Dupuis. Informed consen. Rotterdam: Erasmus Universiteit 17 febr. 1982.

Thung, P. De mens als patient. Het Ziekenhwis 1972, 2, 12,482-485.

Veder-Smit, E: Patienrenbeleid. Brief vande Staatssecretaris wan Volksgezondheid en Milieubygiene aan de Voorzitter wan de Tweede Kamer der Staten Generaal. Leidschendam: 1981.

Verwey, J.A. De moeilijke weg tot verpleegkunde ... en verder. Hoofdstuk 5. In: De verpleegafdefing. bedriffskundige diagnose en therapie. Lochem: De Tijdstroom 1979.

Verwey, J.A. Verpleging in beweging. Lochem-Properinge: De Tijdstroom, 1981.

Visser, A.Ph., Vliert, E. van den, Heine, E.J.H. teren Winmubst, J.A.M.(redactie).Rollen persoonhikeen sociale invioeden op het gedrag. Meppel/Amsterdam: Boom 1983.

Vollebergh. J.J.A. et al. Knelpunten in de bestwutsstwctitw was her algemene ziekenhus. Deventer: Kluwer 1976.

Vroom. H. Work and motivation. New York: Wiley and Sons 1977.

Warlicht, E. E. Stressoren, strains en het hart. Leiden: Universiteit van Leiden 1977.

Weisman, C. et all. Job savisfaction among hospural hurses: a longitudinal study. Baltivnore: John Hopkins University 1980, 341-364.

White, C.H. Where have all the nurses gone and why? Hospinals, 1980, May 1, 54-68.

Whyte, F.W. Street comer society: the social sructure of an halian shm. Chicago: University of Chicago Press, 1943.

Williams, H. et al. Nursing acrivities and acute confusional states. Nursing Research 1979, 28, 1, 25-35.

Wright, D. and Thomas, J. Role-strain among school psychologists in the Midwest. Journal of school psychology. 1982, 20, 2, 96-102.

Zander, K. Primary nursing won"t work ... unless the headnurse lets it fourmalof Nursing Adwmistration. 1977 Oct. 19-23.

Zwaga, P.G.J. De invloed van levderschapsgedrag op rolconflicten, rolambiguïteit, roloverbelasting on rolstess bij (leerling-) verpleegkundigen in algemene ziekenhuizen. Gezondhord en samenheving 1981,2.2, $126-138$.

Zwaga, P.G.J. Rolproblemen in a'gemene ziekenhwizen. Enige effecten. Assen: Van Gorcum 1983. 

Billage 1.

Tabel 34. Gezamentijke raak(on)duidelikheid en (significanted verschillen per ziekenhusisgroonte.

Klein ziekenh. Groot ziekenh. T-waaride sign.

Gemid. s.d. Gemid. s.d.

Taken

Hoofd/Superieuren

Hoofd/Specialisten

Hoofd/Gediplomeenden

Hoofd/Leerlingen

\section{Contacten}

Hoond/Superieuren

Hoofd/Specialisten

Hoofd/Gediplomeenden

Hoofd/Leerlingen

$\begin{array}{lllll}2.2 & 1 .- & 2.2 & 1 .- & -36 \\ 2.3 & .91 & 2.3 & 1.2 & -.03 \\ 2 .- & 1 .- & 2.4 & 1 .- & -1.7 \\ 2.3 & 1 .- & 2.5 & 1 . & -1.1\end{array}$

$\begin{array}{ccccc}2.2 & .98 & 2.1 & 1.1 & .51 \\ 2.2 & .86 & 2.2 & .95 & .47 \\ 2.2 & .97 & 2.1 & 1.1 & .86 \\ 2 .- & 1.1 & 2 .- & 1 .- & .00\end{array}$

Gezamenlike takk(on)duidelikheid en (significanke) verschillen wassen type ziekenafdeling.

Chirurg. afd. Interne alid. T-wate sign.

Gemid. s.d. Gemid, s.d.

\section{Taken}

Hoofd/Superieuren

$\begin{array}{rrrrr}2.3 & 1.1 & 2 . & .97 & .87 \\ 2.2 & 1 .- & 2.4 & .96 & -.59 \\ 2.3 & .90 & 2.4 & 1.2 & -.25 \\ 2.9 & .70 & 2.3 & 1.200 & 2.17\end{array}$

.04

Hoofd/Gediplomeerden

Hoofd/Leeringen

$$
2 .
$$

\section{Contacten}

Hoofd/Superieuren

Hoofd/Specialisten

Hoofd/Gediplomeerden

Hoofd/Leerlingen

$\begin{array}{cccccc}2.2 & 1.2 & 2 . & .97 & .83 & \\ 2.4 & .81 & 2.4 & .90 & -.15 & \\ 1.8 & .85 & 2.8 & .83 & -\mathbf{3 . 6 8} & .001 \\ 2.1 & 1.1 & 2.1 & 1.3 & .10 & \end{array}$

Klein ziekenhuis: functieclassificatie I-2. Groot ziekenhuis: functieclassificatie 3 - 4 en Academ ziekenhuis. 


\section{Bijlage 2.}

Tabel 35. Gezamenlike laakloniduidelijkheid en (significante) verschillen wassen type ziekerafdeling.

Chirurg.afd, Gynaec.afd. Twaarde sign.

Gemid. s.d. Gemid. s.d.

\section{Taken}

Hoofd/Superieuren

Hoofd/Specilalisten

Moold/Gediplomeerden

Hoofd/Leerlingen

$\begin{array}{rrrrr}2.3 & 1.1 & 2.2 & .91 & .39 \\ 2.2 & .99 & 2.3 & 1.2 & -.22 \\ 2.3 & .90 & 2 . & .97 & .79 \\ 2.9 & .70 & 2.2 & .90 & 2.95\end{array}$

.005

\section{Contacten}

Hoofd/Superieuren

Hoofd/Specialisten

Hoofd/Gediplomeerden

Hoold/Leerlingen

$\begin{array}{ccccc}2.2 & 1.2 & 2.2 & .79 & .08 \\ 2.3 & .81 & 2.2 & 1.1 & .55 \\ 1.8 & .85 & 2.2 & 1.1 & -1.1 \\ 2.1 & 1.1 & 2.1 & .97 & .61\end{array}$

Chirurg. afd. Overige afd. T-waarde sign.

Gemid. s.d. Gemid. s.d.

\section{Taken}

Hoofd/Superieuren

Hoofd/Specialisten

Hoofd/Gediplomeerden

Hoofd/Leerlingen

$\begin{array}{ccccc}2.3 & 1.1 & 2.2 & 1.1 & .36 \\ 2.2 & .99 & 2.2 & 1.1 & .08 \\ 2.3 & .90 & 2.1 & .91 & .81 \\ 2.9 & .70 & 2.2 & 1.2 & 2.22\end{array}$

.032

Contacten

Hoofd/Superieuren

Hoofd/Specialisten

Hoold/Gediplomeerden

Hoofd/Leerlingen

$\begin{array}{rrrrr}2.2 & 1.2 & 2.1 & 1.2 & .34 \\ 2.4 & .81 & 1.8 & .71 & 2.45 \\ 1.8 & .85 & 1.8 & .96 & .05 \\ 2.1 & 1.1 & 1.7 & .87 & 1.31\end{array}$

Interne afd. Gynaec. afd. T-waarde sign.

Gemid. s.d. Gemid. s.d.

\section{Taken}

Hoofd/Superieuren

Hoold/Specialisten

Hoofd/Gediplomeerden

Hoold/Leerlingen

\section{Contacten}

Hoofd/Superieuren

Hoold/Specialisten

Hoold/Gediploneerden

Hoofd/Leerlingen

$\begin{array}{rcccr}2 .- & .97 & 2.2 & .92 & -.52 \\ 2.4 & .96 & 2.3 & 1.2 & .30 \\ 2.4 & 1.2 & 2 .- & .97 & .89 \\ 2.3 & 1 .- & 2.2 & .90 & .51\end{array}$

$\begin{array}{rrrrr}2 .- & .97 & 2.2 & .79 & -.92 \\ 2.4 & .90 & 2.2 & 1.1 & .63 \\ 2.8 & .83 & 2.2 & 1.1 & 1.96 \\ 2.1 & 1.3 & 2 .- & .97 & .42\end{array}$


Bijlage 3.

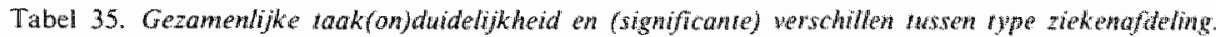
(Nervolg)

Interne ald. Overige afd. T-waarde sign.

Gemid. s.d. Gemid. s.d.

\section{Taken}

Hoofd/Superieuren

Hoold/Specialisten

Hootd/Gediplomeerden

Hoofd/Leerlingen

$\begin{array}{rrrrr}2 .- & .97 & 2.2 & 1.1 & -.47 \\ 2.4 & .96 & 2.2 & 1.1 & .62 \\ 2.4 & 1.2 & 2 .- & .91 & .91 \\ 2.3 & 1 .- & 2.2 & 1.2 & .29\end{array}$

Contacten

Hoold/Superieuren

Hoofd/Specialisten

Hoofd/Gediplomeerden

Hoofd/Leerlingen

$\begin{array}{rrrrrr}1.9 & .97 & 2.1 & 1.2 & -.44 & \\ 2.4 & .90 & 1.8 & .71 & 2.39 & .022 \\ 2.8 & .83 & 1.8 & .96 & 3.43 & .002 \\ 2.1 & 1.3 & 1.7 & .87 & 1.01 & \end{array}$

Gynaec, afd. Overige afd. T-wate sign.

Gemid. s.d. Gemid s.d.

\section{Taken}

Hootd/Superieuren

Hoofd/Specialisten

Hoofd/Gediplomeerden?

Hoofd/Leerlingen

$\begin{array}{ccccr}2.2 & .92 & 2.2 & 1.1 & .00 \\ 2.3 & 1.2 & 2.2 & 1.1 & .28 \\ 2 .- & .97 & 2 .- & .91 & .00 \\ 2.2 & .90 & 2.2 & 1.2 & -.15\end{array}$

\section{Contacten}

Hoofd/Superieuren

Hoofd/Specialisten

2.2

2.2

Hoofd/Gediplomeerden

Hoofd/Leerlingen

2.-

.79
1.1
1.1
.9

2.1

1.2

.31

1.1

1.8

.71

1.37

.97

1.8

1.7

.96

.87

1.08

.70 
Bijlage 4.

Tabel 36. Gezamenlijke raakron)duidelijkheid en (significante) verschillen sussen regio's.

Westen Midden
Gemid. s.d. Gemid. s.d. Taarde sign.

\section{Taken}

Hoofd/Superieuren

Hoold/Specialisten

Hoofd/Gediplomeerden

Hoofd/Leerlingen

\section{Contacten}

Hoofd/Superieuren

Hoofd/Specialistem

Hoofd/Gediplomeerden

Hoofd/Leerlingen

$\begin{array}{ccccr}2 .- & 1.1 & 2.2 & .97 & -.78 \\ 2.2 & 1.1 & 2.4 & .97 & -.44 \\ 2.2 & .98 & 2 .- & 1- & .67 \\ 2.5 & 1.1 & 2.4 & .93 & .47\end{array}$

$2.1 \quad 1 .-\quad 2.4 \quad 57 \quad-1.25$

$\begin{array}{lllll}2.2 & .97 & 2.1 & .83 & .72\end{array}$

2.- $\quad 1--\quad 2 .-\quad .94 \quad-.27$

$2 .-1 .-\quad 1.9 \quad 1.1 \quad 38$

Westen Zuiden T-waarde sign.

\section{Taken}

Foold/Superieuren

Hoofd/Specialisten

Hoofd/Gediplomeerden

Hoofd/Leerlingen

\section{Contacten}

Hoofd/Superieuren

Hoofd/Specialisten

Hoofd/Gediplomeerden

Hoofd/Leerlingen

$\begin{array}{ccccr}2 .- & 1.1 & 2.4 & .81 & -\Perp .58 \\ 2.2 & 1.1 & 2.3 & 1.2 & -.32 \\ 2.2 & .98 & 2.3 & 1 .- & -.47 \\ 2.5 & 1.1 & 2.3 & 1.1 & .64\end{array}$

$\begin{array}{ccccr}2.1 & 1 .- & 1.9 & 1.1 & .51 \\ 2.2 & .97 & 2.3 & .92 & -.07 \\ 2 .- & 1 .- & 2.5 & 1 .- & -1.77 \\ 2 .- & 1 .- & 2 .- & 1 .- & -.13\end{array}$

Midden Zuiden T-waarde sign.

Gemid. s.d. Gemid. s.d.

\section{Taken}

Hoofd/Superieuren

Hoofd/Specindisten

Hoofd/Gediploneerden

Hoofd/Leerlingen

\section{Contacten}

Hoold/Supericuren

Hoofd/Specialisten

Hoold/Gediploneerden

Hoofd/Leerlingen

$\begin{array}{ccccc}2.2 & .97 & 2.4 & .81 & -.82 \\ 2.4 & .97 & 2.3 & 1.2 & .08 \\ 2 .- & 1 .- & 2.3 & 1 .- & -1.1 \\ 2.4 & .93 & 2.3 & 1.1 & .23\end{array}$

$\begin{array}{rrrrr}2.4 & .97 & 1.9 & 1.1 & 1.68 \\ 2.1 & .83 & 2.3 & .92 & -.81 \\ 2 .- & .94 & 2.5 & 1.0 & -1.57 \\ 1.9 & 1.2 & 2 .- & 1.1 & -.49\end{array}$




\section{Bijlage 5 .}

Tabel 37. Erwaren rol (on)dudelijkheid en (signficante) werschillen per ziekenhwisgoote.

\begin{tabular}{|c|c|c|c|c|c|}
\hline & $N$ & Gem. & s.d. & $F$-warde & Sign. \\
\hline $\begin{array}{l}\text { Klein ziekenhuis (funcriecl. } \\
1-2 \text { ) }\end{array}$ & 41 & 14.8 & 3.5 & 1.31 & \\
\hline $\begin{array}{l}\text { Groot ziekenhuis (functied. } \\
3-4-\mathrm{acad} \text {.) }\end{array}$ & 40 & 14.2 & 4.1 & & \\
\hline
\end{tabular}

Tabel 38. Ervarem rol(on)duidelijheid en (significante) verschillen per type ziekendfdeling.

\begin{tabular}{|c|c|c|c|c|c|}
\hline & $\mathbb{N}$ & Gien. & s.d. & F-warde & Sign. \\
\hline $\begin{array}{l}\text { Chirurgische afdelingen } \\
\text { Interne affelingen }\end{array}$ & $\begin{array}{l}21 \\
19\end{array}$ & $\begin{array}{l}14.3 \\
14.7\end{array}$ & $\begin{array}{l}2.7 \\
3.5\end{array}$ & 1.73 & \\
\hline $\begin{array}{l}\text { Chirurgische afdelingen } \\
\text { Gynaecologische afdelingen }\end{array}$ & $\begin{array}{l}21 \\
19\end{array}$ & $\begin{array}{l}14.3 \\
14-\end{array}$ & $\begin{array}{l}2.7 \\
5.9\end{array}$ & 4.9 & .001 \\
\hline $\begin{array}{l}\text { Chirurgische afdelingen } \\
\text { Owerige afdelingen }\end{array}$ & $\begin{array}{l}21 \\
19\end{array}$ & $\begin{array}{l}14.3 \\
15.3\end{array}$ & $\begin{array}{l}2.7 \\
2.6\end{array}$ & $1 .-$ & \\
\hline $\begin{array}{l}\text { Interne afdelingen } \\
\text { Gynaccologische afdelingen }\end{array}$ & $\begin{array}{l}19 \\
19\end{array}$ & $\begin{array}{l}14.7 \\
14 .-\end{array}$ & $\begin{array}{l}3.5 \\
5.9\end{array}$ & 2.8 & .033 \\
\hline $\begin{array}{l}\text { Interne afdelingen } \\
\text { Overige afdelingen }\end{array}$ & $\begin{array}{l}19 \\
19\end{array}$ & $\begin{array}{l}14.7 \\
15.3\end{array}$ & $\begin{array}{l}3.5 \\
2.6\end{array}$ & 1.7 & \\
\hline $\begin{array}{l}\text { Gynatecologische afdelingen } \\
\text { Overige afdelingen }\end{array}$ & $\begin{array}{l}19 \\
19\end{array}$ & $14 .-$ & $\begin{array}{l}5.9 \\
2.6\end{array}$ & $5 .-$ & .001 \\
\hline
\end{tabular}

Tabel 39. Ervaren rol(on)duidelikheid en (significone) verschillen per regio.

\begin{tabular}{lllll} 
& N & Gem. & s.d. & Fwwarde Sign. \\
Westen van het land & 28 & 14.5 & 3.2 & 1.4 \\
Midden van het land & 27 & 14.9 & 3.9 & \\
& & & & \\
Westen van het land & 28 & 14.5 & 3.2 & 1.8 \\
Zuiden van het land & 26 & 14.2 & 4.3 & \\
Midden wan het land & 27 & 14.9 & 3.9 & 1.2 \\
Zuiden van het land & 26 & 14.2 & 4.3 & \\
\hline
\end{tabular}


Bijlagen 6 en 7 .

Tabel 40. Ervaren rol (on) duidelijh herd.

Relatie met:

Chi-kwadrat

sign.

Ziekenhüisgrootte

16.50

Type atldeling

86.60

31.23

sign.

Relatic met:

r

$-.01$

Leeftijd

.04

$-.00$

- 


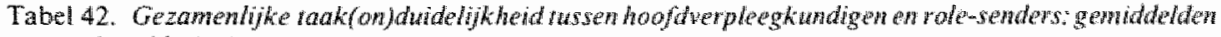
en standaarddewiatle.

$$
1 \text { II III IV }
$$

Algem. hvpl. Rigide hvpl. Flexibele hwpl. Verschil Rig./1ex $(\mathbb{N}=81) \quad(\mathbb{N}=37) \quad(N=38) \quad$ t-test sign, versch. M. s.d. M. s.d. M. s.d. kolom il en llt

\section{Taken}

\begin{tabular}{|c|c|c|c|c|c|c|c|c|}
\hline Hooldwerpl.-supericur & 2.2 & .98 & 2.2 & .80 & 2.2 & 1.2 & .03 & 一 \\
\hline Hoordwerpl.-specialist & 2.3 & 1.- & 2.3 & 1.1 & 2.4 & 1.1 & -.39 & $-m$ \\
\hline Hoofdwerpl.-gediplom. & 2.2 & $1 .-$ & $2 .-$ & .91 & 2.3 & 1.1 & -1.34 & - \\
\hline Hoofdxerpl.-leerling & 2.4 & 1.- & 2.3 & $1 .-$ & 2.6 & 1.- & -1.31 & 一 \\
\hline Role-set & 8.9 & 2.8 & 8.4 & $3-$ & 9.5 & 2.3 & -1.75 & - \\
\hline \multicolumn{9}{|l|}{ Contacten } \\
\hline Hoofdverpl.-superieur & 2.1 & 1.- & 2.3 & 1.2 & $2 .-$ & .90 & 1.12 & - \\
\hline Hoofdverpl-specialist & 2.2 & .90 & 2.3 & .94 & 2.1 & .82 & 1.20 & - \\
\hline Hoofdverpll-gediplom. & 2.2 & 1.- & 2.3 & 1.1 & $2 .-$ & $1 .-$ & .90 & - \\
\hline Hoofdwerpl-teerling & $2-$ & 1.1 & $2,-$ & 1.2 & 1.9 & .89 & .43 & - \\
\hline Role-set & 7.7 & 3.6 & 8.2 & 3.6 & 7.2 & 3.4 & 1.30 & - \\
\hline
\end{tabular}

Tabel 43. Gezamenlike taak(on) duidelijkheid wssen hoofdwerple gkundigen en role-senders: geniddelden en standaarddeviatie.

\begin{tabular}{|c|c|c|c|}
\hline \multirow{3}{*}{$\stackrel{\text { I }}{\text { Algem. hrvpl. }}$} & & & \\
\hline & II & III & \multirow{4}{*}{$\begin{array}{l}\quad \text { IV } \\
\text { Verschil gunstig/ } \\
\text { minder gunstig } \\
\text { t-test sign. verseh. } \\
\text { kolom II en III } \\
\text { l-waarde sign. }\end{array}$} \\
\hline & $\begin{array}{l}\text { IVWSS } \\
\text { gunstige relatie }\end{array}$ & $\begin{array}{l}\text { IVWSS } \\
\text { minder gunstige }\end{array}$ & \\
\hline & & & \\
\hline s.d. & s.d. & M. $\quad$ s.d. & \\
\hline
\end{tabular}

Taken

\begin{tabular}{|c|c|c|c|c|c|c|c|c|}
\hline Hoofidverpl.-superieur & 2.2 & .98 & 2.4 & I.1 & 2.1 & .85 & 1.30 & - \\
\hline Hoofdwerpl uspecialist & 2.3 & $1 .-$ & 22 & 1.2 & 2.5 & .39 & -1.16 & - \\
\hline Hooldwerpl.-gediplom. & 2.2 & $1 .-$ & 2.2 & 1.1 & 2.1 & .93 & .28 & - \\
\hline Hoofdwerpl.-leerling. & 2.4 & $1 .-$ & 25 & $1 .-$ & 2.4 & $1 \ldots$ & .64 & - \\
\hline Role-set & 8.9 & 2.8 & 9.- & 3.4 & 9.- & $2 .-0$ & -.13 & $\ldots$ \\
\hline
\end{tabular}

\section{Contacten}

\begin{tabular}{lllllllll} 
Hoofdverpl.-superieur & 2.1 & $1 .-$ & $2 .-$ & $1 .-$ & 2.3 & 1.2 & -1.34 & - \\
Hoofdverpl.-specialist & 2.2 & .90 & 2.3 & .91 & 2.1 & .91 & .60 & - \\
Hoofdwerpl.-gediplom. & 2.1 & $1 .-$ & 2.2 & 1.1 & 2.1 & 94 & .17 & - \\
Hoofdwerpl.-leerling & 2. & 1.1 & 2.1 & $1 .-$ & 1.8 & 1.1 & 1.28 & - \\
\hline Role set & 7.7 & 3.6 & $8 .-$ & 3.7 & 7.7 & 3.6 & .36 & - \\
\hline
\end{tabular}


Bijlage 10 .

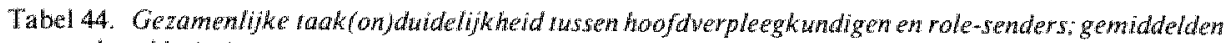
en standacirddeviatic.

\begin{tabular}{|c|c|c|c|}
\hline 1 & [I] & III & LW \\
\hline Algem, hvpl. & $\begin{array}{l}\text { IVWGL } \\
\text { gurstige relatie }\end{array}$ & $\begin{array}{l}\text { IVWGL } \\
\text { milinder gunstige }\end{array}$ & $\begin{array}{l}\text { Verschil gunstig/ } \\
\text { minder gunstige }\end{array}$ \\
\hline$(N=81)$ & $(N=34)$ & $(N=43)$ & kolom Ill en II \\
\hline M. $\quad$ s.d. & M. s.d. & M. $\quad 5 . \mathrm{d}$ & l-waarde sign. \\
\hline
\end{tabular}

Taken

Hoofdverpl.-superieur

Hoofdverpl,-specialist

Hoofoverpl.-gediplom.

$\begin{array}{lll}2.2 & .98 & 2 . \\ 23 & -\end{array}$

Hoofdverpl.-leerling

$2.2 \quad 1 . \quad 2.3$

1.1

1.1

2.2

$2.2 \quad 1 .-$

1.91

. 1

1.1

$2=\quad .94$

$2.4 \quad 1 . \quad 2.5$

$2.4 \quad 1 .-$

1.30

1.1

$\begin{array}{llll}8.9 & 2.8 & 9.2 & 2.8\end{array}$

8.6

2.9

1. 17

\section{Contacten}

Hoofidwerpl.-superieur

Hoofdwerpl -specialist

Hoofd werpl.-gediplom.

Hoofdwerpl.-leerling

$\begin{array}{rrrrrrrr}2.1 & 1 .- & 2.2 & 1.1 & 2.1 & 1 .- & .47 & - \\ 2.2 & .90 & 2.2 & .89 & 2.2 & .92 & -.13 & - \\ 2.2 & 1 .- & 2.3 & .81 & 2 .- & 1.2 & 1.37 & - \\ 2 .- & 1.1 & 2 .- & 1 .- & 2 .- & 1.2 & .42 & -\end{array}$

Role-set

$7.7 \quad 3.6$

$8 . \quad 3.4$

7.

3.8

.6 
Bijlage 11 en 12.

Tabel 45. Correlaties wassen gezamenlijke raak (ondidudelijk he id bij WWSS gumsig en MWSS minder gunstig en ervaren rol(on)dudelijk heid wan hoofdverpletgk undigen.

\begin{tabular}{|c|c|c|}
\hline I & II & 111 \\
\hline $\begin{array}{l}\text { IVWSS } \\
\text { gunstigg } \\
(N=41)\end{array}$ & $\begin{array}{l}\text { IVWSS } \\
\text { minder gunstig } \\
(\mathbb{N}=38)\end{array}$ & Verschil gunstig/minder gunstig \\
\hline sign. & sign. & $Z$-waarde \\
\hline
\end{tabular}

\section{Taken}

\begin{tabular}{lrrrrrr} 
Hoofdverpl.-superieur & -.03 & - & .05 & - & .084 & - \\
Hoofdverpl.-specialist & -.12 & - & .08 & - & .173 & - \\
Hoofdwerpl.-gediplom & .11 & - & .08 & - & .127 & - \\
Hoofdverpl.-leerling & .02 & - & -.17 & - & .644 & - \\
\hline Role-set & .02 & - & .04 & - & .084 & -
\end{tabular}

\section{Contacten}

\begin{tabular}{lrlllll} 
Hoofdverpl-superieur & -.20 & - & -.12 & - & .347 & - \\
Hoofdverpl.-specialist & -.02 & - & -.22 & - & .864 & - \\
Hoofdverpl.-gediplom. & .15 & - & -.14 & - & .042 & - \\
Hoofdverpl.-leerling & -.02 & - & -.17 & -.644 & .64 \\
\hline Role-set & .04 & - & .08 & - & .169 & - \\
\hline
\end{tabular}

Tabel 46. Correlaties tussen gezamenlijke laak(onjdudelijkheid bij WWGL gumstig en IVWGL winder gunstig en ervaren ral(on) dusdelijk heid wan hoof dverpleegkundigen.

\begin{tabular}{|c|c|c|}
\hline I & II & III \\
\hline $\begin{array}{l}\text { IVWGL } \\
\text { gunstig } \\
\text { (N 34) }\end{array}$ & $\begin{array}{l}\text { IVWGL } \\
\text { minder gunstig } \\
\text { (N 43) }\end{array}$ & Verschil gunstig/minder gunstig \\
\hline $\mathrm{r}$ sign. & sigrn. & Z-watarde \\
\hline
\end{tabular}

\section{Taken}

\begin{tabular}{lrrrrrr} 
Hoofdverpl.-supericur & -.05 & - & .06 & - & .042 & - \\
Hoofdverpl.-specialist & -.18 & - & .06 & - & .508 & - \\
Hoofdverpl.-gediplom. & .04 & - & .09 & - & .208 & - \\
Hoofidwerpl-Leerling & -.14 & - & -.00 & - & .587 & - \\
\hline Role-set & .04 & - & .02 & - & .083 & -
\end{tabular}

\section{Contacten}

\begin{tabular}{lrlllll} 
Hoofdverpl-superieur & -.17 & - & -.39 & .01 & $1 .-$ & - \\
Hoofdverpl.-speciallist & -.00 & - & -.19 & - & .800 & - \\
Hoofdverpl-gediplom. & .06 & - & -.05 & - & .042 & - \\
Hoofdverpl.-leerling & .15 & - & -.13 & - & .083 & - \\
\hline Role-set & .04 & - & -.18 & - & .592 & - \\
\hline
\end{tabular}




\section{Bijlage 13.}

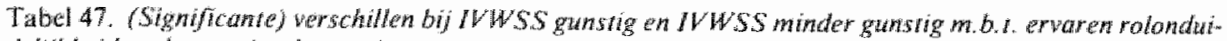
delikh heid en de reacties daarop."

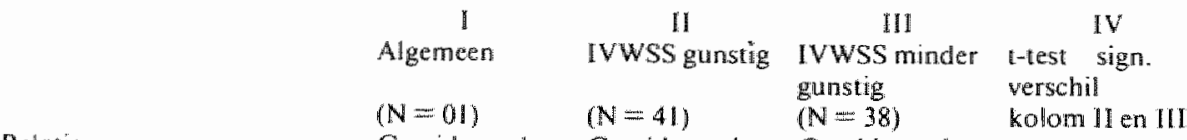

Gemid. s.d

Gemid. s.d.

Gemid. s.d.

Ervaren rolonduidelijk. heid met:

14.7

14.88

3.36

14.35

3.45

.69

\section{Stressoren}

Verantwoordelojkheid voor anderen

Niet gebruik kunnen maken van kennis

Rolconflict

Toekomstonzekerheid

$\begin{array}{rrrrrrr}14.84 & 2.41 & 14.70 & 2.46 & 14.94 & 2.37 & -.44 \\ 7.12 & 2.44 & 6.98 & 2.27 & 7.27 & 2.69 & -.51 \\ 5.25 & 2.04 & 5.05 & 1.82 & 5.53 & 2.26 & -1.02 \\ 10.07 & 3 .- & 9.82 & 2.84 & 10.36 & 3.30 & -.74\end{array}$

\section{Strains}

Bezorgdheid m.b.t.

eigen functioneren

Gezondheidsklachten

8.34

2.54

17.86

4.37

8.20

18.10

2.52

8.27

17.54

$2.48-.12$

Klachten psychische

conditie

26.06

$4.43 \quad 25.80$

$3.95 \quad 25.88$

3.72

.56

Verlies zelfwatrdering

$5.99 \quad 1.84$

5.95

1.88

5.97

$4.59-.08$

* N.B. Het aantal respondenten kan zich binnen de kolommen enigszins wijzigen. 
Bijlage 14.

Tabel 48. (Significante) werschillen bij IVHGL gunstig en IVWGL minder gunstig m b. 1. erwaren notondudelijk heid en de reacties daurop. *

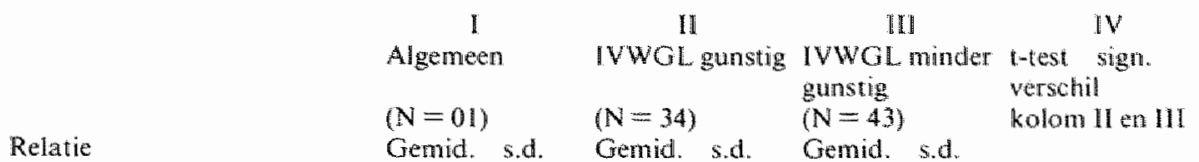

Ervaren rolonduiclelijk-

heid met:

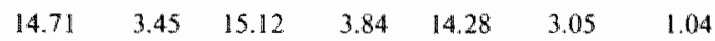

\section{Stressoren}

Verantwoordelijkheid

woor anderen

$\begin{array}{rrrrrrr}14.84 & 2.41 & 14.54 & 2.69 & 14.98 & 2.12 & -.77 \\ 7.12 & 2.44 & 7.03 & 2.32 & 7.05 & 2.55 & -.04 \\ 5.25 & 2.04 & 5.18 & 1.93 & 5.38 & 2.16 & -.42 \\ 10.07 & 3 . & 9.97 & 3.20 & 10.16 & 3 .- & -.25\end{array}$

Niet gebruik kunnen

maken van kennis

Rolconflict.

Gemid. s.d. Gemid. s.d. Gemid. s.d

Toekomstonzekerheid

$\begin{array}{rrrrrrr}8.34 & 2.54 & 8.32 & 2.62 & 8.33 & 2.59 & -.02 \\ 7.86 & 4.37 & 17.85 & 4.63 & 17.76 & 4.07 & .09 \\ 26.06 & 4.43 & 26.56 & 5.05 & 25.57 & 3.97 & .91 \\ 5.99 & 1.84 & 6 & 1.63 & 6.08 & 2 .- & -.18\end{array}$

\section{Strains}

Bezorgdheid m.b.t.n

eigen functioneren

Gezondheidsklachten

Klachten psychische

conditie

5.99

$1.84 \quad 6-1.63$

$6.08 \quad 2-\quad-.18$

* N.B. Het æantal respondenten kan zich binnen de kolommen enigszins wijzigen. 


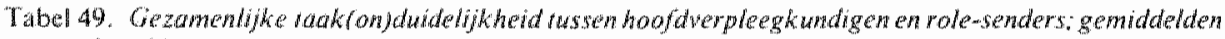
en standaarddeviane.

\begin{tabular}{|c|c|c|c|}
\hline$\frac{1}{\text { Algemeen }}$ & $\begin{array}{l}\quad 11 \\
\text { Superieur } \\
\text { gunstige } \\
\text { relatie } \\
(\mathrm{N}=38)\end{array}$ & $\begin{array}{l}\quad \text { III } \\
\text { Superietr } \\
\text { minder gunstige } \\
\text { dellatie } \\
(\mathrm{N}=38)\end{array}$ & $\begin{array}{l}\qquad \mathrm{UV} \\
\text { Verschili gunstig } \\
\text { minder gunstig }\end{array}$ \\
\hline M s. s. & M. s.d. & M. s.d. & T-waarde sign. \\
\hline
\end{tabular}

\begin{tabular}{|c|c|c|c|c|c|c|c|c|}
\hline \multicolumn{9}{|l|}{ Taken } \\
\hline Hoofd verpl..specialist & $\begin{array}{l}2.2 \\
2.3\end{array}$ & .98 & $\begin{array}{l}2.3 \\
23\end{array}$ & $\begin{array}{l}1.1 \\
98\end{array}$ & $\begin{array}{ll}2.1 \\
23\end{array}$ & .88 & .80 & - \\
\hline Hooldverpl.-gediplom. & 2.2 & $1 .-$ & 2.2 & 1.1 & 2.2 & 97 & .00 & - \\
\hline Hobfdverpl, leerling & 2.4 & $1 .-$ & 2.5 & $1 .-$ & 2.3 & 1.1 & .98 & - \\
\hline Rolle-sett & 8.9 & 28 & 8.9 & 3.- & 8.8 & 2.8 & .24 & - \\
\hline \multicolumn{9}{|l|}{ Contacten } \\
\hline Hoofdverpl-superieur & 2.1 & 1.- & 2.2 & $\| .1$ & 2 & 1.- & .87 & - \\
\hline Hoofdverpl -specialist & 2.2 & .90 & 2.- & .93 & 2.2 & .81 & -.79 & - \\
\hline Hoofdverpl.-gediplom. & 2.1 & 1. & 2. & .94 & 2.3 & 1.1 & -1.11 & - \\
\hline Hoofdverpl.mleerling & $2 .-$ & 1.1 & 2. & 1.2 & 1.9 & $1 .-$ & .74 & - \\
\hline Role-set & 7.7 & 3.6 & 7.3 & $4-$ & 7.9 & 3.4 & -.68 & - \\
\hline
\end{tabular}

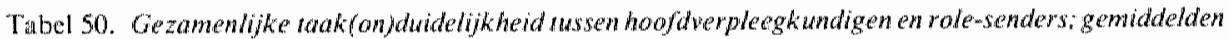
en standaarddemiatie.

\begin{tabular}{llll}
$\begin{array}{l}\text { I } \\
\text { Algemeen }\end{array}$ & \multicolumn{1}{c}{ II } & \multicolumn{1}{c}{ III } & \multicolumn{1}{c}{ IV } \\
gunstige relatie & $\begin{array}{l}\text { Collega"s } \\
\text { minder gunstige } \\
\text { relatie }\end{array}$ & Verschil gunstig/ \\
minder gunstig \\
(N $81 \mathrm{~N} 45)$
\end{tabular}

\section{Taken}

Hoofdverpl-superieur

Hooldverpl.-specialist

Hoofdwerpl.-gediplom.

Hoofdverpl.-Aerling

$\begin{array}{rrrrrrrr}2.2 & .98 & 2.2 & 1.1 & 2.2 & .94 & .03 & - \\ 2.3 & 1 .- & 2.2 & 1.1 & 2.4 & 1 .- & -.73 & - \\ 2.2 & 1 .- & 1.9 & .95 & 2.3 & 1 . & -1.90 & - \\ 2.4 & 1 . & 2.4 & .90 & 2.3 & 1.1 & .37 & - \\ 8.9 & 2.8 & 8.3 & 2.7 & 8.9 & 2.9 & -.87 & -\end{array}$

\section{Contacten}

Hooldverpl-superieur

Hoofdverpl.-specialist

Hooldverpl.-gediplom.

Hoofdverpl-lerling

\begin{tabular}{rrrrrrrr}
2.1 & $1 .-$ & $2 .-$ & .91 & 2.2 & 1.2 & -.55 & - \\
2.2 & .90 & 2.2 & $1 .-$ & 2.1 & .75 & .67 & - \\
2.1 & $1 .-$ & 1.7 & .92 & 2.4 & 1.25 & -2.87 & .005 \\
$2 .-$ & 1.1 & $2 .-$ & .94 & 1.9 & 1.2 & .21 & - \\
\hline 7.7 & 3.6 & $7 .-$ & 3.6 & 7.8 & 3.8 & -.96 & - \\
\hline
\end{tabular}




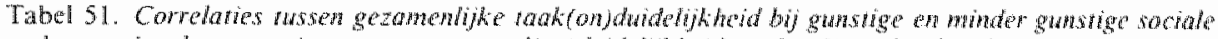

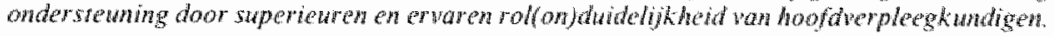

1

Superieuren gurstige ondersteuning (N 38 )

r sign.
11

Superieuren minder yunstige ondersteuning (N 38)

$r$ sign. Zwarde sign.

\section{Taken}

Hoofdverpl,-superieur

Hoofoverpl.-specialist

Hoofdverpl-gediplom.

Hoofdverpl--leerling

.09

.10

.17

.02
III

Verschil gunstig minder gunsistig

\begin{tabular}{lcccccc}
\hline Role-set & .14 & - & -.07 & - & .300 & - \\
\hline $\begin{array}{l}\text { Contacten } \\
\text { Hoofdverpl.-superieur }\end{array}$ & -.18 & - & -.09 & - & .385 & - \\
Hoofdverpd.-specialist & -.14 & - & -.05 & - & .381 & - \\
Hoofdverpl.-gediplom. & -.09 & - & -.01 & - & .335 & - \\
Hoofdverpl.-leerling & -.16 & - & .03 & - & .548 & - \\
\hline Role-set & -.23 & - & -.01 & - & .937 & - \\
\hline
\end{tabular}

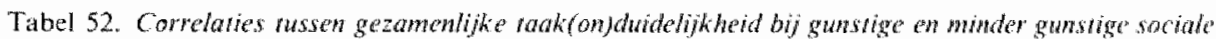
ondersteuning door collega"s en ervaren rolfond duidelikheid wan hoofdwerpleeghumdigen.

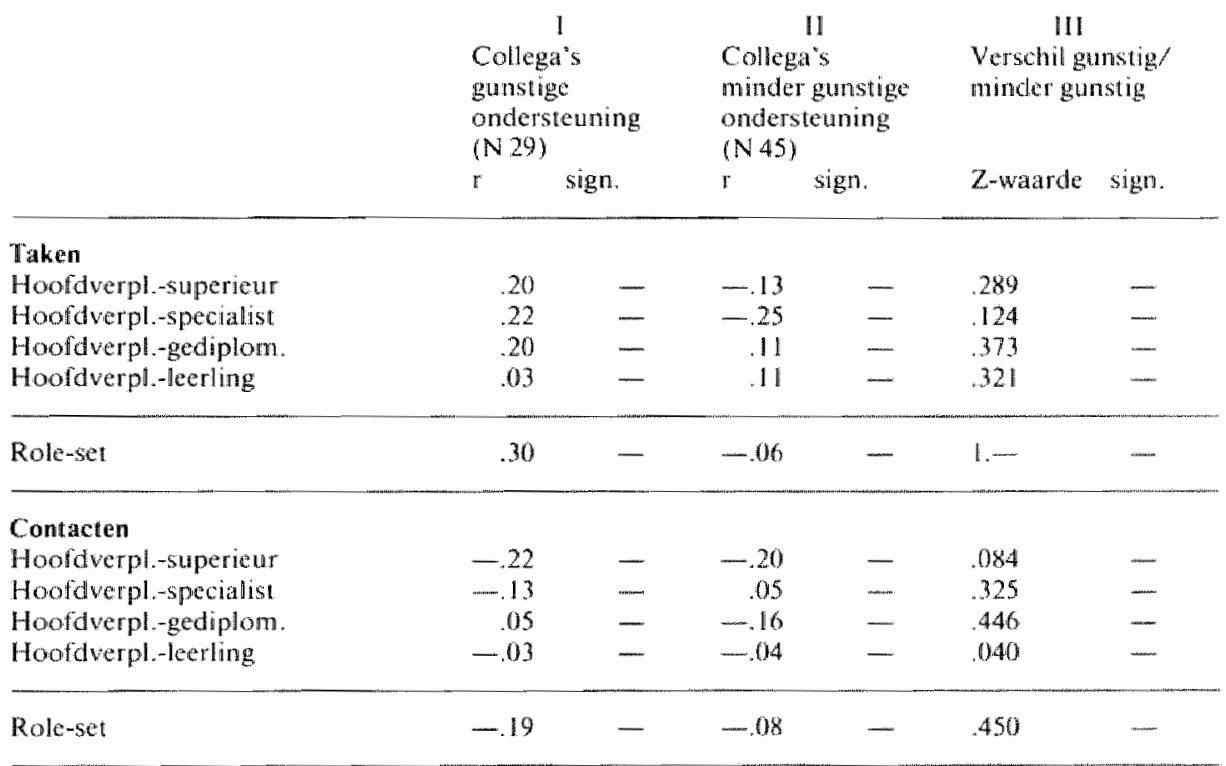




\section{Curriculum vitae}

Anneke van den Bergh-Braam, geboren 16-1-1927 te Gendt (Gld.).

$\mathrm{Na}$ de beroepsopleiding voor verpleegkundige te hebben doorlopen vervolgde zij haar studie aan de hogere school voor verpleegkundigen te Nijmegen, waar zij in 1954 cum laude afstudeerde.

Van 1954 - 1961 was zij docente, waarnemend hoofd van de school voor verpleegkundigen aan het academisch ziekenthuis "Radboud" te Nijmegen. In deze periode heeft zij gedurende en jaar stage gelopen in ziekenhuizen en opleidingsscholen in Engeland en Frankrijk.

$\mathrm{Zij}$ is auteur van verpleegkundeboeken in de serie "In Goede Handen".

Van $1972-1977$ studeerde zij westerse sociologie aan de katholieke universiteit te Nijmegen met als afstudeerrichting "methoden en technieken van sociaal-wetenschappelijk onderzoek".

Van 1979 - 1982 was zij als wetenschappelijk medewerkster verbonden aan de vakgroep "psychologie van arbeid en organisatie" van de katholieke universiteit te Nijmegen.

Vanaf oktober 1982 is zij als wetenschappelijk hoofdmedewerkster verbonden aan de capaciteitsgroep verplegingswetenschappen rijksuniversiteit Limburg, Maastricht. 